University of South Florida

DIGITAL COMMONS

Digital Commons @ University of

@ UNIVERSITY OF SOUTH FLORIDA

South Florida

USF Tampa Graduate Theses and Dissertations

USF Graduate Theses and Dissertations

$11-23-2020$

\title{
Phenomenological Study on Lived Experiences of Assigned Expatriates
}

John Alan Hennings

University of South Florida

Follow this and additional works at: https://digitalcommons.usf.edu/etd

Part of the Business Administration, Management, and Operations Commons

\section{Scholar Commons Citation}

Hennings, John Alan, "Phenomenological Study on Lived Experiences of Assigned Expatriates" (2020).

USF Tampa Graduate Theses and Dissertations.

https://digitalcommons.usf.edu/etd/8547

This Dissertation is brought to you for free and open access by the USF Graduate Theses and Dissertations at Digital Commons @ University of South Florida. It has been accepted for inclusion in USF Tampa Graduate Theses and Dissertations by an authorized administrator of Digital Commons @ University of South Florida. For more information, please contact digitalcommons@usf.edu. 
Phenomenological Study on Lived Experiences of Assigned Expatriates

by

John Alan Hennings

A dissertation submitted in partial fulfillment

of the requirements for the degree of

Doctor of Business Administration

Muma College of Business

University of South Florida

Co-Major Professor: T. Grandon Gill, DBA

Co-Major Professor: Dejun Kong, Ph.D.

Priya Dozier, DBA

Robyn Lord, DBA

Tianxia Yang, Ph.D.

Date of Approval:

22 November 2020

Keywords: Cross-cultural, Cultural, Intercultural, Selection, Expatriate, Repatriation, Selection

Copyright ( 2020 , John A. Hennings 


\section{DEDICATION}

To all those who serve abroad and strive to do the right thing, despite constant stress and conflicting roles and demands. Know that you have inspired me. 


\section{ACKNOWLEDGEMENTS}

This was a long process. The work was mine, but the means to do it came from many sources. I thank the following groups of people for their endless patience, support, wisdom, and good humor: my family; the University of South Florida (USF) faculty and staff, especially those associated with the Doctorate of Business Administration at Muma College of Business (like Michele and Lauren!); my church, The Grove Bible Chapel Tampa; and my cohorts (2019 and 2020). I could not have done it without you.

Thank you to the Veterans Administration and the USF Office of Veteran Success for making sure this degree was funded. Thank you to my interview subjects for sharing not only their time and attention, but an important part of their lives so that others could learn from their experiences. I also want to highlight the contribution of those who attended my presentation at the Engaged Management Scholarship Conference at Temple University in 2018. Several of your suggestions made it in the final product. Unfortunately, the only one I have documented is Dr. Lomax Campbell, who made a key point about cultural humility, among others. There are others whose contributions are mentioned in the body of the dissertation, and many others whose names or contributions I have unfortunately forgotten. Thank you anyway.

On a personal note, as I did in my master's thesis, I will thank my savior, the Lord Jesus Christ, who also served as an assigned expatriate. 


\section{TABLE OF CONTENTS}

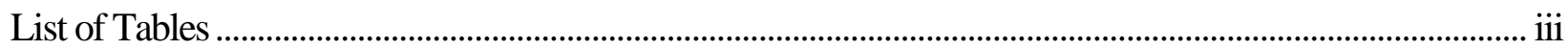

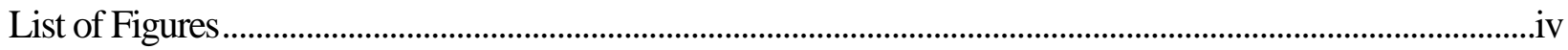

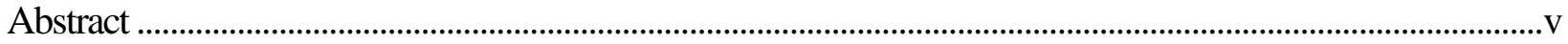

Chapter One: Introduction............................................................................................................................

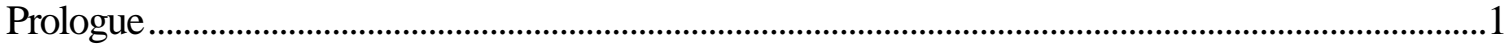

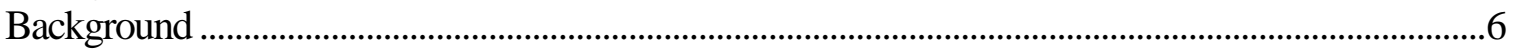

Chapter Two: Literature Review..........................................................................................................

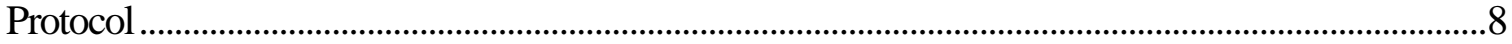

Part 1: Reasons to Send, Reasons to Go, and the Role of Expatriate Expectations..............................9

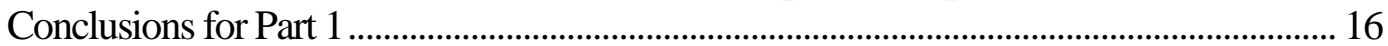

Part 2: Selection and Preparation............................................................................................................ 17

Conclusions for Part 2 ....................................................................................................... 17

Part 3: Lived Experiences Abroad: Adjustment, Effectiveness, and Other Factors ........................... 33

Conclusions for Part 3 ............................................................................................................. 33

Part 4: Repatriation, Reintegration, and Outcomes .......................................................................... 42

Conclusions for Part 4 ............................................................................................................. 42

Conclusions for Literature Review Overall ....................................................................................... 56

Way Ahead and Research Questions .............................................................................................. 58

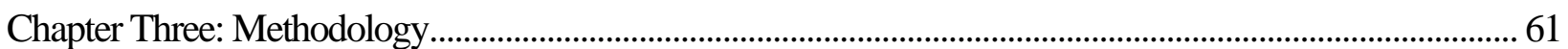

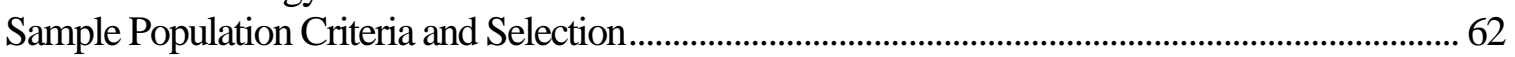

Pilot Interview ………………………………………………………………………………. 63

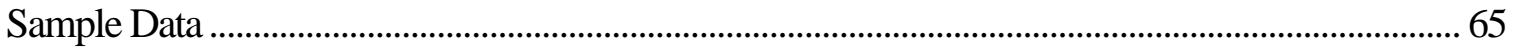

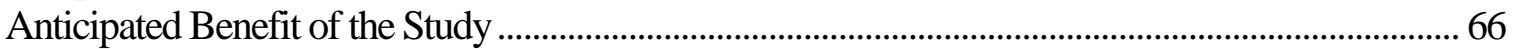

Principal Research .................................................................................................................................... 67

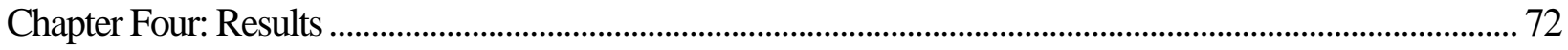

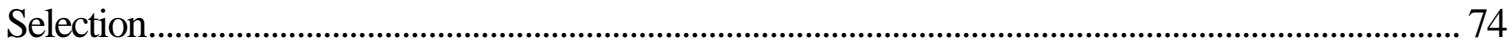

Selection: Findings ………………………………………………………………………... 78

Selection: Recommendations for Practice ................................................................................... 80

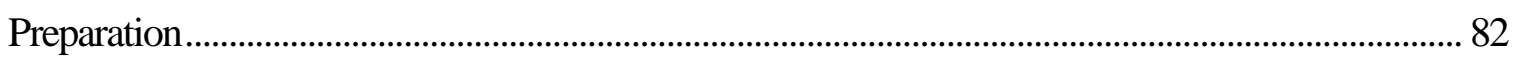

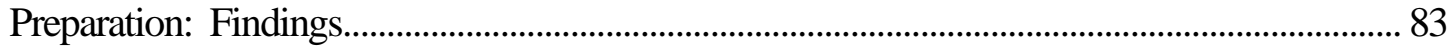

Preparation: Recommendations for Practice ………………………………………………….... 88

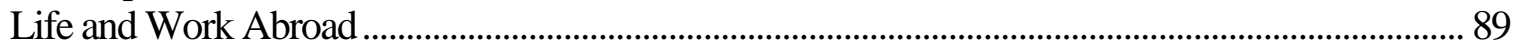




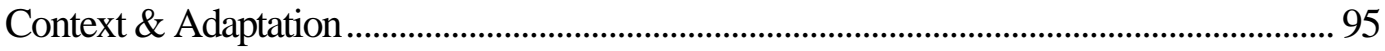

A New Standard of Living .......................................................................................... 95

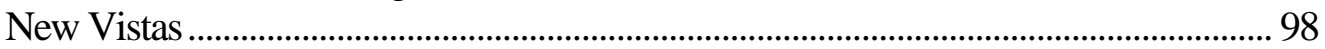

A New Way of Life.......................................................................................................... 99

Bias, Bigotry, Sex, and Corruption in the Host Culture .................................................... 99

Stereotypes and Assumptions ....................................................................................... 102

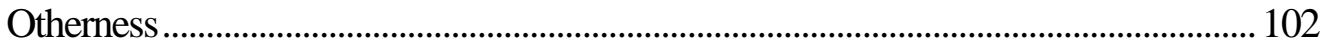

Adjustment and Acceptance (or, Learning to Swim) .................................................... 103

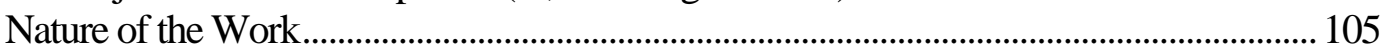

Ambiguity, Autonomy, Task Variety, Interaction With Elites, and Field Work ........ 105

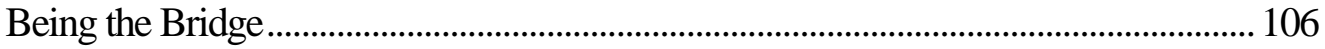

Building Relationships................................................................................................... 107

Observation and Inquiry .................................................................................................. 108

People Adapting to You ..................................................................................................... 109

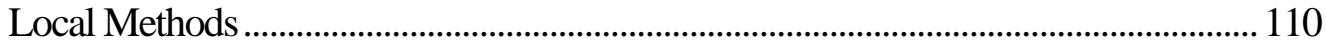

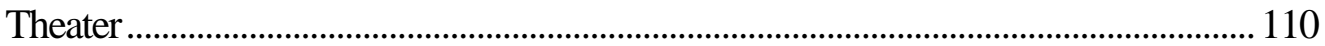

The Effect of the Expatriate Community........................................................................... 110

The Effect of External Events and Circumstances .......................................................... 111

Physical Well-Being Affecting Interactions..................................................................... 111

Challenge and Success.................................................................................................. 111

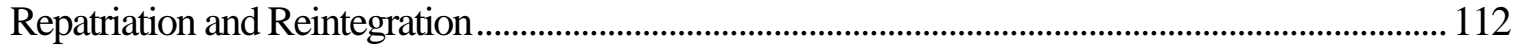

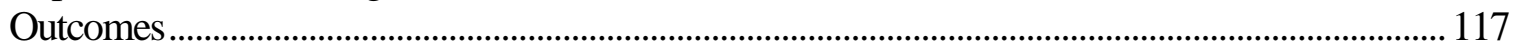

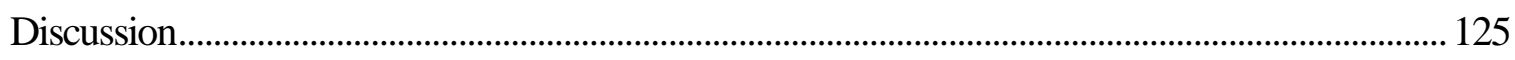

Areas for Future Research.............................................................................................................. 131

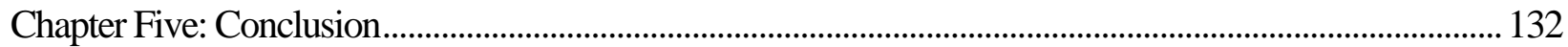

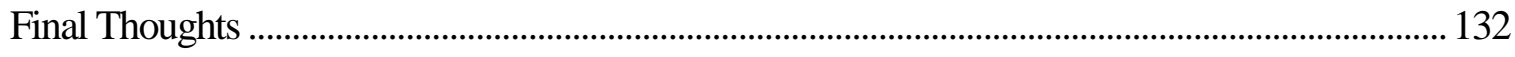

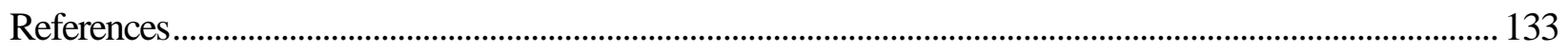

Appendix 1: Exemplar Quotations From Interview Transcripts..............................................148

Appendix 2: Methods of Assessing Intercultural Competence .................................................176

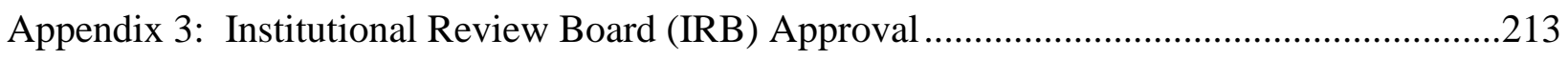

Appendix 4: What is Intercultural Competence and Why is it Important to Business? .............215 


\section{LIST OF TABLES}

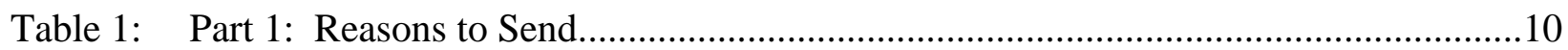

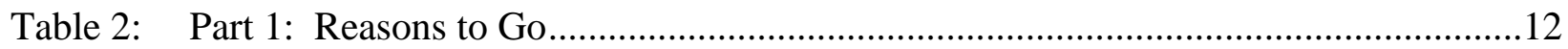

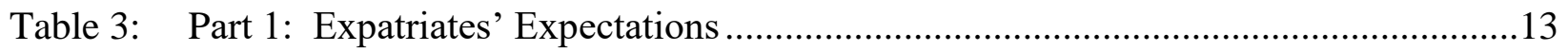

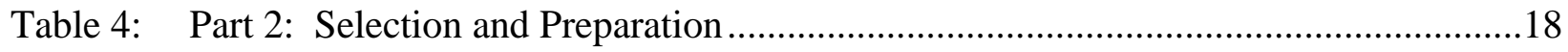

Table 5: Part 3: Lived Experiences Abroad: Adjustment, Effectiveness, Other Factors .........34

Table 6: Part 4. Repatriation, Reintegration, and Outcomes............................................43

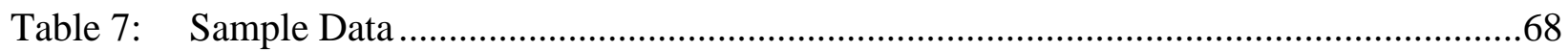

Table 8: Themes from Phenomenological Interviews of Assigned Expatriates .......................73

Table 9: Expanded Inset from Table 1 - Themes Subordinate to "Assigned Expatriate"........74

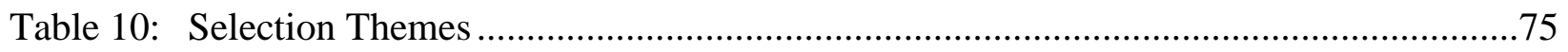

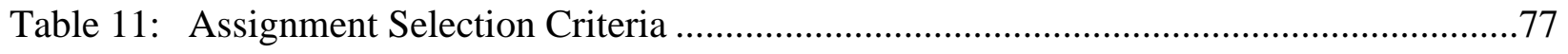

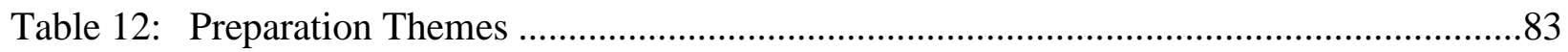

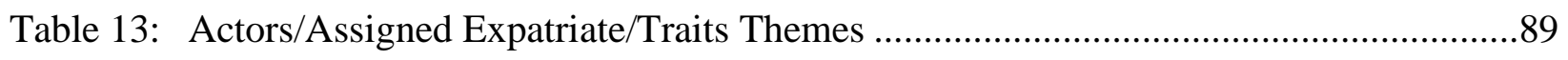

Table 14: Actors/Assigned Expatriate/Actions Themes ..................................................91

Table 15: External Actors (Actors/Host Country Nationals \&Actors/Employers) Themes ........92

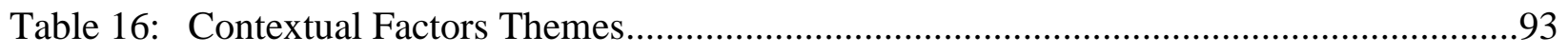

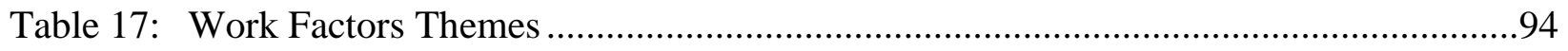

Table 18: Repatriation and Reintegration Themes...........................................................113

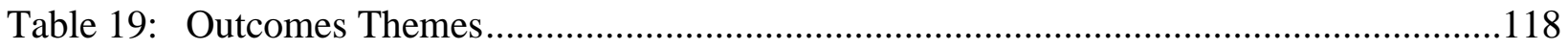




\section{LIST OF FIGURES}

Figure 1: The Expatriate Experience Pipeline ................................................................59

Figure 2: Integrated Model of Intercultural Competence ..............................................127

Figure 3: Intercultural Competence and the Assigned Expatriate Experience .........................128

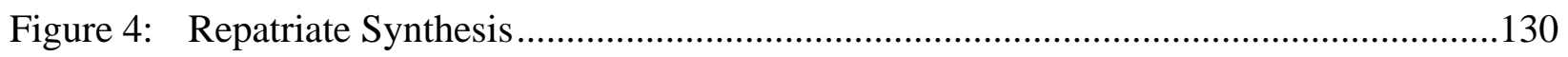




\begin{abstract}
The academic community has researched expatriate work for over five decades, but the problems identified in the 1960 s persist. This study focuses on the assigned expatriate, defined as an individual on overseas assignment for his or her employer. It uses qualitative semistructured interviews and a phenomenological approach to answer questions research has largely ignored: What are the distinctive characteristics of life and work as an assigned expatriate? How do assigned expatriates perceive their expatriate experience? The scope includes selection, preparation, life and work abroad, and repatriation, investigating the experiences of expatriates on assignments for the U.S. military, civil government, and the private sector. The purpose is to inform the human resource functions of job analysis and design, which are necessary guides to selection, training, evaluation, and compensation. The results should also inform potential expatriates of what they can expect, better informing their career and lifepath decision. The study concludes that the successful assigned expatriate's experience during life and work abroad is defined by constant learning, the building of relationships vital to the expatriate's success and well-being, and engagement with and adaptation to the new environment - particularly the host nation culture. The study also concludes assigned expatriates perceive their experience as transformative, permanently altering their self-image, worldview, and lifepath. Successful expatriates report a greater interest in other cultures and the world outside their borders, an increased ability to shift perspective, and a greater need to see the impact of their work.
\end{abstract}




\section{CHAPTER ONE:}

\section{INTRODUCTION}

\section{Prologue}

In late 2012, I was in the middle of a military deployment to western Afghanistan when I was tasked to return to the U.S. and spend a week training others about to deploy. After that welcome but surreal intermission and an arduous journey, I returned to learn that my friend and colleague - I will call him "George" - was being "fired" and sent to Kabul. George worked in a violent, corrupt district at the southern end of our province. The district governor, his most important relationship, refused to meet with him anymore. I boarded a helicopter to break the news myself. In-flight, my thoughts were on how we got to this point.

George and I worked for Special Operations Task Force West, or SOTF-West. SOTF-West was a patchwork "team of teams" scattered across $40 \%$ of Afghanistan, training Afghan Commandos, fighting poverty and disease, and hunting down terrorists in the dead of night. I was their liaison for the province of Herat. It was my job to develop (and then exploit) relationships with every Afghan politician, police chief, and Army general; every international diplomat and development worker; and every businessman and philanthropist who could help us accomplish our many missions. In corporate terms, I was an in-country "fixer." George was my counterpart at the district level.

George and I were "AFPAK Hands," also known as "Afghan Hands" when it was not politic to mention Pakistan. The brainchild of General Stanley McChrystal, the Hands program was modeled after at least two historic examples. The first was T.E. Lawrence, or "Lawrence of 
Arabia," an Orientalist in the British Royal Army who unified the Arab tribes against the Ottomans in World War I. The second, the "China Hands," were military officers, diplomats, and journalists who knew China and informed American policy regarding China before, during, and after World War II. The closest modern military equivalent was a "foreign area officer," but those took years of schooling and travel to make. McChrystal needed a cadre that was "Afghan good enough" right away, and so created the Hands program. For each deployment, we went through six to eight months of training - linguistic and cultural training to make us effective and tactical training to keep us alive. Once suitably prepared, Hands filled a variety of jobs that required working closely with Afghans.

So, what had gone wrong? George was exceptionally intelligent and knowledgeable. Prior to the AFPAK Hands program, he had served in civil affairs - a U.S. Army occupational specialty focused entirely on working with civilians in foreign cultures. He was supporting an Army special forces team, a civil affairs team, and others who were conducting village stability operations, or bottom-up counterinsurgency. If anyone could make this difficult, ambiguous, and dangerous job work, it should have been him.

But I had seen George in action, so I already knew what had happened. His great knowledge had led him into a trap. He was "stuck on transmit" when he met with the district governor. He was focused on sharing the solutions he just knew would work and not on listening, or even observing how he was being received. By the time I had left Savannah, the governor had decided enough was enough.

This scenario was not new, even if it was hitting closer to home than ever before. It was one instance of what I had come to see as an ongoing mystery. Several AFPAK Hands had failed spectacularly in positions all over Afghanistan, while others succeeded just as spectacularly. I 
was reportedly among the effective ones, but I thought that was to be expected. Like George's civil affairs time, my intelligence assignments had prepared me to build rapport and relate to foreign cultures beyond the standard training that all Hands received. However, my counterparts in neighboring provinces included two Marines and an Army officer with no additional training, and they were very successful, also.

Why had they employed that minimal training so effectively when others could not? It was more than problems maintaining rapport. Some Hands were flummoxed by ambiguity. Afghan Hands often had to figure out for themselves what needed to be done and then craft a way to make it happen. After fifteen years of jobs with very clear expectations, many officers could not do that. Others were too timid to go "outside the wire," or too reckless to be trusted. When these problems came to a head, the now-former Hands were sent to inward-facing staff positions or ignominiously sent home and returned to their career fields. I assumed that the problem was unique to my generation of military officers. Those in previous conflicts must have been more adept, or at least more consistent.

It was another year before I learned I was wrong. I read a biography of General "Wild Bill" Donovan, the founder of the Office of Strategic Services, or OSS. The OSS was the CIA forerunner that employed agents and partisan forces against the Axis Powers of World War II. I learned that, despite the careful tutelage of Great Britain's MI-6, Donovan had the same difficulties in Europe and Southeast Asia as the Hands in Afghanistan. One recruit would "wire" a city or a region in occupied territory, recruiting assets in every port, government office, and tavern needed to support espionage and sabotage. Another would implode on the battlefield, accomplishing little or even getting his agents killed. Prior to deployment, there was nothing to 
distinguish the successful recruit from the unsuccessful one (Waller, 2011). Encouraged and intrigued that my experience was not unique, I looked for opportunities to investigate further.

Three years later, I was beginning a doctoral program in business administration at the University of South Florida (USF). That required a research topic, and I knew I wanted to do something about working cross-culturally. I remembered from a training course a decade before that multinational corporations also experienced grave setbacks when they were ignorant of other cultures, so I thought the topic would be useful beyond the military. My professors agreed. One USF professor from the College of Arts and Sciences (Dr. Adib Farhadi) introduced me to a friend of his, a retired Special Forces colonel named Sean Ryan. Dr. Ryan had just completed a dissertation on the high value of language training in cross-cultural work, even if the training was only minimal. Dr. Ryan agreed to meet with me. He and his former team sergeant, retired Command Sergeant Major Thomas Rupert, helped me understand that the phenomenon I had observed was real, it was just as common in international business, and it had been written about for decades, but never solved. He called the invisible quality that made the difference "intercultural adaptability."

Through subsequent research, I learned that intercultural adaptability was only one of many terms for a set of traits, attitudes, and behaviors that enabled people to adapt and work effectively in societies that had different operating systems. "Cross-cultural competence," "cultural agility," and "cultural intelligence" were some of the others (see Appendix 4).

The literature also revealed that the negative outcomes I had observed were called "expatriate failure." This phenomenon was well-known in the private sector, and the instances in the Hands program were typical in their frequency and cost. The following paragraph is reused from other doctoral program assignments: 
Expatriate failure occurs when people who leave home to work abroad are ineffective at adjusting, building relationships, and accomplishing their appointed objectives. This often results in early return or separation from their organization. One widely cited estimate reports that $16-40 \%$ of expatriate assignments fail to accomplish the goals of the company. Estimates of early return rates vary even more widely, between $20 \%$ and $70 \%$ (Graf \& Harland, 2005). Costs for a typical expatriate employee failure (lost business, preparation expenses, etc.) have been estimated at between $\$ 200,000$ and $\$ 1.2$ million. In addition, compensation packages for expatriates can be 2.5 to 5 times the base salary, driving costs even higher. Furthermore, failure often significantly damages the careers and self-esteem of the once-promising assignees. Even successful expatriates often have problems adjusting upon their return, resulting in reduced performance, failure to advance, or the loss of key personnel (Mesmer-Magnus \& Viswesvaran, 2008).

This last point also paralleled my experience. When I returned from Herat, I remember feeling like an imposter in my own uniform, because I was not the same person who had left. I do not mean the hypervigilance, intrusive memories, and overemotional reactions that are common for those returning from a combat zone. I had those symptoms, too, but there was more. I had become accustomed to representing my country to senior leaders in a foreign government; devising solutions to wicked problems and having the authority to implement them; and being an on-call "expert" (or the best available substitute) regarding political intrigue on Afghanistan's frontier with Iran. Now I was returning to one of those jobs with clear expectations. Most of what I had learned no longer mattered. My creativity, while still useful, was far less important than my attention to detail. My horizons had been irrevocably broadened, but the scope of my work narrowed. 


\section{Background}

The literature and my own experience confirmed that intercultural competence was only one of the issues regarding those who work overseas for an extended period and then return. There were decades of research on the topic covering a host of questions. Why do organizations send people overseas at all, when there are competent managers in the host country? How do they select and prepare expatriates? What can expatriates do to accelerate their adjustment, and what behaviors should they avoid? What does the expatriate need from the home office, and vice versa? Why is reintegrating into the headquarters so difficult? The literature had useful (if not necessarily complete) answers to all these questions. The literature also reported that those answers were generally unknown to practice. The exception to that rule was the global mobility consulting industry that had arisen to fill the knowledge gap, but even those experts were vastly underutilized because organizations had no idea how much they did not know.

The focus of my research is what researchers Yvonne McNulty and Chris Brewster (2017) have called "assigned expatriates", i.e., individuals on overseas assignments for their employers. Assigned expatriates are a subset of "business expatriates" whom McNulty and Brewster define as "legally working individuals who reside temporarily in a country of which they are not a citizen in order to accomplish a career-related goal, being relocated abroad either by an organization [assigned expatriates], by self-initiation or directly employed within the hostcountry." More specifically, the focus is assigned expatriates who work closely with host country nationals (HCNs) and their organizations. This excludes the many in the U.S. military and some corporations whose jobs allow them to stay within the bubble of a military base or a company town, working primarily with their compatriots. 
The literature review portion of this dissertation will share the high points of the findings of research on assigned expatriates over the last several decades. The review also reveals a significant gap in the knowledge on this topic, which I will attempt to partially fill through a phenomenological study of assigned expatriates. Through analysis of the literature and the lived experiences of assigned expatriates, I hope to provide insights useful to both sending organizations and those who go forward on their behalf. 


\section{CHAPTER TWO:}

\section{LITERATURE REVIEW}

\section{Protocol}

The purpose of this paper is to briefly summarize the results of research on assigned expatriates, and more specifically, several sub-topics likely to be of use to sending organizations and prospective expatriates. The sub-topics are arranged chronologically to correspond with the breadth of the expatriate experience:

Part 1: Reasons to Send, Reasons to Go, and the Role of Expatriate Expectations

Part 2: Selection and Preparation

Part 3: Lived Experiences Abroad: Adjustment, Effectiveness, and Other Factors

Part 4: Repatriation, Reintegration, and Outcomes

Academic research into expatriates began in earnest in the 1960s (Selmer, 2017), especially with the publication of research on Peace Corps volunteers (Guthrie \& Zetrick, 1967; Smith, 1966). Given the multiple sub-topics and the breadth of time, the literature review herein is really multiple literature reviews covering 55 years of scholarship divided into the four time periods of 1965-1989, 1990-1999, 2000-2010, and 2011-2020. To cover such a broad length of time, I modeled my methods after those of a somewhat similar review published in the Annual Review of Organizational Psychology and Organizational Behavior (Kraimer et al., 2016). As in that article, the use of multiple time periods avoids biasing earlier work which has had greater time to be cited. The review herein covers considerably more time than that of Kraimer and her colleagues, but is more narrowly focused. All searches used the ABI/Inform Global database to 
search the abstracts of peer-reviewed articles in scholarly journals for the following keywords on an "OR" basis (i.e., any of these keywords in the abstract would count as a "hit"):

"international assignment"

"international assignee"

"global assignment"

"global assignee"

"international experience"

"international experiences"

"global experience"

"global experiences"

Searches also included the terms "expatriate" and "expatriates"; "repatriate" and "repatriates"; or both sets, depending on topic. Relevancy was one key criterion for selection; influence, measured as number of times other publications cited the work, was another. Due to lack of time for citations to accumulate, the influence criterion did not apply to the most recent time period. I also prioritized empirical work over conceptual and theoretical, unless the conceptual or theoretical work became significantly influential. I supplemented the search results with relevant material cited within the resulting articles or spotted in previous research.

\section{Part 1: Reasons to Send, Reasons to Go, and the Role of Expatriate Expectations}

Searches in Part 1 included the keywords "reason," "role," "motivation," and "expectations" on an "OR" basis with each other and an "AND" basis with the keywords above. In other words, results must include at least one of the keywords above and at least one of the four additional keywords. These initial searches also included results for dissertations and theses. 


\section{Table 1. Part 1: Reasons to Send}

\begin{tabular}{|c|c|}
\hline Source & Summary of Relevant Findings \\
\hline Zeira, 1976 & $\begin{array}{l}\text { - Multinationalization of the management } \\
\text { - Integration of the organization as a whole } \\
\text { - Control of the foreign work site, both directly by expatriates and by knowledge transfer from overseas to home } \\
\text { - A variety of benefits resulting from change. These included increasing organizational adaptability; inserting } \\
\text { fresh ideas; creating opportunities for developing expertise; and invigorating both careers and ways of thinking } \\
\text { that had grown stagnant. }\end{array}$ \\
\hline $\begin{array}{l}\text { Galbraith and } \\
\text { Edström, } 1976 \\
\text { (most } \\
\text { sophisticated } \\
\text { framework) }\end{array}$ & $\begin{array}{l}\text { - Bureaucratic control, which permitted decentralization, enabling "local responsiveness, discretion, and } \\
\text { flexibility without sacrificing overall coordination and control." } \\
\text { - Control by socialization, which shaped the foreign managers so that they would do what the main headquarters } \\
\text { would want them to do anyway - again, permitting local discretion } \\
\text { - Knowledge transfer increases knowledge of the foreign operation and its decisions --increases trust, affording } \\
\text { the overseas office greater power and flexibility within the system } \\
\text { Expatriates provide information to headquarters both during and after their assignment } \\
\text { - Create and strengthen lasting ties with a local network of contacts } \\
\text { Management development } \\
\text { Expat learns the culture and value systems of the foreign office, breaking stereotypes and enabling him or } \\
\text { her to communicate with overseas offices and judge their actions more accurately } \\
\text { Expat develops commitment to and identification with the organization - especially true of those } \\
\text { employees with multiple overseas assignments, who sacrificed much for the central organization and came } \\
\text { to regard it as one of the few constants in their life }\end{array}$ \\
\hline Tung, 1982 & $\begin{array}{l}\text { - American multinationals - to start up new business operations or had greater technical expertise than local } \\
\text { hires } \\
\text { - Japanese multinationals - simply chose the best candidate for the positions } \\
\text { - European multinationals - used overseas assignments to develop their management personnel }\end{array}$ \\
\hline
\end{tabular}

${ }^{1}$ In 2001, Harzing would zoomorphize these control roles as "bears," "bumblebees," and "spiders." 
Table 1 (Continued)

\begin{tabular}{|c|c|}
\hline Source & Summary of Relevant Findings \\
\hline $\begin{array}{l}\text { Zeira and } \\
\text { Banai, } 1987\end{array}$ & $\begin{array}{l}\text { - Use knowledge of home office policies to stand up a new operation overseas } \\
\text { - Provide expertise that is necessary, but locally unavailable } \\
\text { - Help develop host country managers }\end{array}$ \\
\hline $\begin{array}{l}\text { Brewster, } \\
1988\end{array}$ & $\begin{array}{l}\text { - Cited staffing and management development as the reasons most often discussed } \\
\text { - Added organizational development } \\
\text { - National representation (public relations and meeting client expectations) and control of foreign operations - at } \\
\text { least as important but less likely to be mentioned }\end{array}$ \\
\hline Kobrin, 1988 & $\begin{array}{l}\text { - Control } \\
\text { - Development of international expertise among managers } \\
\text { - Increase subsidiaries' identification with the organization and its global strategy }\end{array}$ \\
\hline $\begin{array}{l}\text { Petison \& } \\
\text { Johri, } 2008\end{array}$ & $\begin{array}{l}\text { When foreign employees' job knowledge and/or management ability were low, technical knowledge transfer and } \\
\text { bureaucratic control (as discussed above by Edström and Galbraith) were important. When local knowledge and } \\
\text { ability were high, the network building and socialization roles of expatriates were more important. }\end{array}$ \\
\hline $\begin{array}{l}\text { Lakshman \& } \\
\text { Lakshman, } \\
2017\end{array}$ & $\begin{array}{l}\text { Suggested that the roles in which expatriates serve their organization evolve over time, depending upon corporate } \\
\text { strategy and stage of internationalization. }\end{array}$ \\
\hline $\begin{array}{l}\text { Tsegaye et al., } \\
2019\end{array}$ & $\begin{array}{l}\text { nother purpose of expatriates is to spark innovation in their subsidiaries, but cross-cultural adjustment level } \\
\text { ediates the expatriate's tendency to innovate }\end{array}$ \\
\hline
\end{tabular}


Table 2. Part 1: Reasons to Go

\begin{tabular}{|c|c|}
\hline Source & Summary of Relevant Findings \\
\hline $\begin{array}{l}\text { Miller \& Cheng, } \\
1978\end{array}$ & $\begin{array}{l}\text { For first-time expatriates: } \\
\text { ○ Pay } \\
\text { ○ Career development } \\
\circ \text { Professional development } \\
\text { ○ Appeal of the job itself (regardless of location) } \\
\text { - For those who volunteered for subsequent overseas assignments - same as above, plus increased } \\
\text { responsibility in overseas jobs } \\
\text { Increased responsibility was a bigger factor, even though some believed subsequent overseas } \\
\text { assignments hurt their chances for promotion } \\
\text { - In both groups, some employees simply prefer living and working in the overseas location }\end{array}$ \\
\hline $\begin{array}{l}\text { Feldman \& Thomas, } \\
1992\end{array}$ & $\begin{array}{l}\text { Those who chose to go overseas voluntarily were more likely to have a successful placement, perhaps } \\
\text { because it gave those who were less committed an opportunity to self-select out. }\end{array}$ \\
\hline $\begin{array}{l}\text { Schruijer \& } \\
\text { Hendriks, 1996; } \\
\text { Abkhizer, } 1999\end{array}$ & $\begin{array}{l}\text { - Length of assignment was an important factor; three years was as long a posting as people were } \\
\text { generally willing to accept } \\
\text { - Unwillingness of a spouse to emigrate, unstable governments, and poor medical care all led candidates } \\
\text { to refuse international assignments }\end{array}$ \\
\hline Boies, 1999 & $\begin{array}{l}\text { - Challenge } \\
\text { - Autonomy } \\
\text { - Responsibility } \\
\text { - Financial rewards } \\
\text { - Opportunities to travel and learn from other cultures } \\
\text { Found that candidates' family situations (e.g., whether or not they had children at home or elderly parents in } \\
\text { the home country) factored into their desire to go overseas }\end{array}$ \\
\hline Haines et al., 2008 & $\begin{array}{l}\text { - Found correlation between intrinsic motivation for an international assignment and willingness to accept } \\
\text { the assignment and communicate in a foreign language } \\
\text { - Extrinsically motivated expatriates perceived more difficulties with the assignment } \\
\text { - Source of motivations (intrinsic or extrinsic) had no effect on their reactions to organizational support }\end{array}$ \\
\hline
\end{tabular}


Table 2 (Continued)

\begin{tabular}{|c|c|}
\hline Source & Summary of Relevant Findings \\
\hline $\begin{array}{l}\text { Minssen \& Schmidt, } \\
2008\end{array}$ & $\begin{array}{l}\text { Researched the German chemical industry; reached bold conclusion that motivation and self-selection were } \\
\text { so important to success in expat assignments that, given those elements, companies did not need to } \\
\text { scientifically select expatriate candidates }\end{array}$ \\
\hline Chen et al., 2010 & $\begin{array}{l}\text { - Expatriates' 1) intrinsic interest in other cultures and 2) confidence in their ability to operate effectively } \\
\text { in those cultures promote work adjustment and consequently job performance; effect was: } \\
\circ \text { More apparent in less supportive work environments } \\
\circ \text { Less apparent when cultural distance was high }\end{array}$ \\
\hline $\begin{array}{l}\text { Oberholster et al., } \\
2013\end{array}$ & $\begin{array}{l}\text { Surveyed religious and humanitarian workers; for that sample: } \\
\text { - Added altruism to the list of motivations, especially for respondents from the developed world } \\
\text { - Added family well-being, mainly for developing world respondents seeking a better life for their family } \\
\text { - Career and economic benefits of international experience remained a significant factor, especially for } \\
\text { those from the developing world }\end{array}$ \\
\hline Presbitero, 2017 & Found intrinsic motivation in religious expatriates helped them use cultural intelligence to adapt effectively \\
\hline Shortland, 2018 & $\begin{array}{l}\text { Found motivations of female assigned expatriates in the oil and gas industry to be similar to those of } \\
\text { assigned expatriates writ large - career development, professional development, and money }\end{array}$ \\
\hline Linder, 2019 & $\begin{array}{l}\text { Compared motivations as performance drivers between assigned expatriates and self-initiated expatriates } \\
\text { (SIEs). Found assigned expatriates were generally more committed to the home organization than the host } \\
\text { organization, but the opposite was true for SIEs. See Table } 3 \text { for further findings. }\end{array}$ \\
\hline
\end{tabular}

Table 3. Part 1: Expatriates' Expectations

\begin{tabular}{|c|c|}
\hline Source & Summary of Relevant Findings \\
\hline $\begin{array}{l}\text { Weiss \& Bloom, } \\
1990\end{array}$ & $\begin{array}{l}\text { Specific to assignments in China, realistic expectations were critical in determining whether the candidate } \\
\text { made a prudent decision to expatriate and whether or not the expatriate succeeded in the role. }\end{array}$ \\
\hline Dunbar \& Bird, 1992 & $\begin{array}{l}\text { Anecdotal evidence on the importance of expectations: Expatriates said that, if they had considered certain } \\
\text { issues prior to their assignment, such as the foreign office's relationship to the parent firm and their } \\
\text { readiness (and their family's readiness) to engage with the culture, their expectations would have been more } \\
\text { accurate. That, in turn, would have significantly reduced their disappointment and frustration. }\end{array}$ \\
\hline
\end{tabular}


Table 3 (Continued)

\begin{tabular}{|c|c|}
\hline Source & Summary of Relevant Findings \\
\hline $\begin{array}{l}\text { Schruijer and } \\
\text { Hendriks, } 1996\end{array}$ & $\begin{array}{l}\text { Realistic job previews (RJPs) could enhance the likelihood of expatriate success, especially if the review } \\
\text { covers more than just the job itself. Other key topics: } \\
\text { - Career development } \\
\text { - Political conditions } \\
\text { - Length of assignment } \\
\text { - Difficulty of spousal adjustment } \\
\text { - Quality of living conditions (e.g. medical facilities) } \\
\text { Consistent with other research on realistic job previews, which have been found to save hiring organizations } \\
\text { money by reducing turnover (Premack \& Wanous, 1985; Office of Personnel Management (n.d.)). }\end{array}$ \\
\hline Lewis, 1997 & $\begin{array}{l}\text { As the expatriate and family are dependent on the hiring organization for far more than they would be in a } \\
\text { domestic assignment, unmet expectations can create unnecessary stress and lower productivity. }\end{array}$ \\
\hline Hauser, 1998 & $\begin{array}{l}\text { Unclear communication of organizational policy on international assignments leads some to refuse the } \\
\text { assignment and those who accept to become dissatisfied with support. }\end{array}$ \\
\hline $\begin{array}{l}\text { Caligiuri \& Phillips, } \\
2003\end{array}$ & $\begin{array}{l}\text { A specific kind of RJP that incorporated a self-assessment enabled candidates to match their skills and traits } \\
\text { with those required by the position. This increased candidates' self-efficacy regarding their ability to make } \\
\text { an informed decision about the assignment and the ability to succeed in the assignment itself. }\end{array}$ \\
\hline $\begin{array}{l}\text { Wang and Hinrichs, } \\
2005\end{array}$ & A model to explain how the effects of RJPs reduce turnover in expatriates \\
\hline $\begin{array}{l}\text { Huei-Fang Chen and } \\
\text { Yung-Ho Chiu, } 2009\end{array}$ & $\begin{array}{l}\text { When expatriate employees perceive that their employers are meeting their expectations (their } \\
\text { psychological contract) regarding pay, recognition, employment security, and career opportunities, they are } \\
\text { more likely to adjust well to their new assignment and have greater commitment to the organization. Used } \\
\text { Black and Gregersen's (1991) stressor-stress-strain model as their theoretical foundation, which explains } \\
\text { how stress that exceeds the expatriate's ability to cope leads to "outcomes such as job dissatisfaction, } \\
\text { psychological withdrawal cognitions, early return, and poor performance." }\end{array}$ \\
\hline $\begin{array}{l}\text { Pate \& Scullion, } \\
2010\end{array}$ & $\begin{array}{l}\text { The increasingly transactional nature of the psychological contract between employers and employees in the } \\
\text { overall labor market affects expatriate employees, as well. Consequently, employee expectations for career } \\
\text { progression and job security are changing, and employees are more likely to use the assignment to increase } \\
\text { their employability. The importance of setting clear expectations before the assignment regarding } \\
\text { remuneration, support from the home office, and opportunities upon return were re-emphasized. }\end{array}$ \\
\hline
\end{tabular}


Table 3 (Continued)

\begin{tabular}{|l|l|}
\hline $\begin{array}{l}\text { Source } \\
\text { Mahajan \& DeSilva, }\end{array}$ & $\begin{array}{l}\text { Summary of Relevant Findings } \\
\text { Suggest that informational and social support from host country nationals (HCNs) may help mitigate the } \\
\text { negative effects of unmet expectations on expatriates - especially those regarding their role. }\end{array}$ \\
\hline Vromans et al., 2013 & $\begin{array}{l}\text { Compared the expectations and experiences of Dutch expatriates in a culturally similar country (Belgium) } \\
\text { and Dutch expatriates in culturally dissimilar country (China). The expats in Belgium expected an easier } \\
\text { adjustment and a higher degree of cultural similarity than they encountered, and the unmet expectations } \\
\text { negatively affected their affective (emotional) adjustment. China's greater cultural distance negatively } \\
\text { affected intercultural adjustment (as expected). Both kinds of adjustment had a direct effect on job } \\
\text { performance. The Belgian experience warns organizations and prospective expatriates not to underestimate } \\
\text { cultural differences. It also (again) emphasizes the importance of accurate expectations. }\end{array}$ \\
\hline Gibson et al., 2015 & $\begin{array}{l}\text { A model of expectation-based interventions for expatriates that included not only RJPs, but also realistic } \\
\text { living condition previews (RLCPs) and the ominously named expectation lowering procedures (ELPs). }\end{array}$ \\
\hline Perera et al., 2019 & $\begin{array}{l}\text { Proposed a model to explain how psychological contract breach (i.e., unmet expectations) affects expatriate } \\
\text { cognition, attitudes, behavior, and outcomes. The model expands the aperture by considering breach not } \\
\text { only between the expatriate and the home office, but also between the expatriate and the host organization. }\end{array}$ \\
\hline Linder, 2019 & $\begin{array}{l}\text { Found assigned expatriates' commitment to the home office came with expectations, usually related to } \\
\text { career progression, and indications that those expectations would not be met could reduce job performance }\end{array}$ \\
\hline
\end{tabular}




\section{Conclusions for Part 1}

At least for the most generalizable circumstances, the academy's understanding of why organizations send employees on expatriate assignments and why the employees agree to go have been largely unchanged since the 1980s. In sum, organizations send personnel abroad to ${ }^{2}$ :

- Solve a staffing or capability gap

- Control or shape the foreign office

- Transfer knowledge between sites
- Develop the organization

- Develop personnel at home and abroad

- Spark innovation ${ }^{3}$

As researchers published less about reasons to send, they published more about expatriates' motivations, expectations, and their effects. Expatriates go abroad for the following benefits:

- Career development

- Professional (capability) development
- Financial compensation

- Appeal of life abroad

- Appeal of the job (increased challenge, autonomy, responsibility)

For the last thirty years, research and theory have repeatedly underscored the importance of intrinsic motivation and the criticality of clear, accurate expectations for the expatriate and his family. These findings complement another recent trend, advocacy for the use of volunteers and the opportunity to self-select out of an assignment without reprisals. Newer contributions have focused on the effects of changes to the business environment or narrower groups within the assigned expatriate set.

\footnotetext{
2 These bullets answer the question in the Introduction, "Why do organizations send people overseas at all, when there are competent managers in the host country?
} 


\section{Part 2: Selection and Preparation}

Searches in Part 2 included the keyword "selection" or "preparation" or "training" in addition to the keywords in the Protocol section. An increase in published work regarding the topics in Parts 2 through 4 justified an escalation of standards, excluding dissertations and theses.

\section{Conclusions for Part $2^{4}$}

In an increasingly globalized economy, assigned expatriates and their success are becoming increasingly important to multinational businesses and other organizations. Over time, and in cooperation with practice, the academic community has identified the personal variables and selection processes most directly related to the adjustment and effectiveness of the assigned expatriate. Excluding the technical and managerial skills also required for domestic assignments, the personal variables include language skills and an array of traits, skills, and attitudes that comprise the constructs cultural intelligence (CQ) and learning goal orientation (LGO). The selection processes that most foster success include the following:

- Exposing employees to the possibility of expatriation early in their career

- Involvement of the candidate's family at the earliest opportunity

- Realistic previews of life and work abroad for both the candidate and the family

- A pool of multiple qualified candidates with opportunities for self-selection

- Career planning prior to expatriation, including designation of the follow-on position

- An open selection process based on well-defined policies, criteria, and objectives

- An assessment of the candidates' personal traits, abilities, attitudes, and biodata (including their previous cross-cultural experiences) related to the assignment

\footnotetext{
${ }^{4}$ This section serves as a partial answer to the question in the Introduction, "How do [organizations or employers] select and prepare expatriates?" More material on this topic is in the Results chapter.
} 
Table 4. Part 2: Selection and Preparation

\begin{tabular}{|c|c|}
\hline Source & Summary of Relevant Findings \\
\hline Hays, 1974 & $\begin{array}{l}\text { Interviewed and surveyed expats and international personnel officers. Job-related abilities were the dominant } \\
\text { factor for both success and failure. After that, relational abilities were more important for fostering success, } \\
\text { and family situation was more important for avoiding failure. }{ }^{5}\end{array}$ \\
\hline Tung, 1981 & $\begin{array}{l}\text { Recommends a contingent approach, tailoring selection and training procedures to the job, as different job } \\
\text { categories require "varying degrees of contact with, knowledge of, and duration of stay in the foreign } \\
\text { country." Groups factors known to contribute to success into four categories: } \\
\text { 1) Technical competence on the job - more difficult to consult with peers and superiors remotely } \\
\text { 2) Personality traits or relational abilities - ability to live and work with people who have different values, } \\
\text { beliefs, manners, and ways of doing business } \\
\text { 3) Environmental variables - government, labor, market, and society are all different } \\
\text { 4) Family situation -- ability of family to adjust } \\
\text { Nevertheless, technical competency is often prioritized at the expense of all else, because: } \\
\text { - Other criteria are not seen as measurable } \\
\text { - Overreliance on training (where that exists), with no consideration to who is most likely to benefit from } \\
\text { and adopt the lessons of training in practice } \\
\text { - Possibly, a belief that lack of technical competence will drive failure quickly and reflect on the selector } \\
5 \text { categories of relational skills training, "presented in ascending order of rigor": } \\
\text { a. Area studies - fact-based / academic; provides context; may reduce fear of the unknown } \\
\text { b. Culture assimilator - essentially discussion of } 75 \text { to } 100 \text { mini-cases describing intercultural encounters } \\
\text { c. Language training } \\
\text { d. Sensitivity training - designed to work on affective level (changing attitudes); can be combined with: } \\
\text { e. Field experiences - visits to country of assignment or nearby "micro-culture" to experience culture shock } \\
\text { Author provides selection-decision flowchart. Study findings: } \\
\text { - Only } 5 \% \text { of responding firms tested for relational ability, despite firms recognizing its importance } \\
\text { - Only } 32 \% \text { provided training, and only a minority of those evaluated training effectiveness } \\
\text { - Rigor in selection and training related inversely to expat's failure to complete assignment. }\end{array}$ \\
\hline
\end{tabular}

\footnotetext{
${ }^{5}$ This is consistent with later findings and seems intuitive when one considers that a family problem can override all other factors, preoccupying the expatriate and even curtailing his assignment.
} 
Table 4 (Continued)

\begin{tabular}{|c|c|}
\hline Source & Summary of Relevant Findings \\
\hline Tung, $1982 \& 1984$ & $\begin{array}{l}\text { Investigated how European and Japanese companies assigned expatriates and achieved a far lower failure rate } \\
\text { (as much as } 75 \% \text { lower) than their U.S. counterparts. } \\
\text { - Difference in selection: Relational skills were treated as equally important to technical proficiency. } \\
\text { - Difference affected the entire expatriation process: Human resources management (as a function and as a } \\
\text { department) had far higher priority and status in Japanese firms than American firms, resulting in an increase } \\
\text { in time and attention paid to expatriates and their success. } \\
\text { - Expatriate success was clearly and directly correlated with the rigor of the associated selection and } \\
\text { training process. }\end{array}$ \\
\hline Tung, 1987 & $\begin{array}{l}\text { Japanese and European multinationals have inherent advantages regarding expatriate assignments. U.S. } \\
\text { multinationals can "catch up" by: } \\
\text { - Adopting a long-term orientation, evinced by: } \\
\text { o Longer expatriate tours } \\
\text { O Support mechanisms for expatriates } \\
\text { - Mentoring - if not by individuals, then by a division focused on overseeing their career path } \\
\text { - "Internationalize" their outlook, increasing the priority and resources devoted to their international market } \\
\text { or supply elements - including priority of staffing } \\
\text { - Significantly increase the depth, length, and rigor of cross-cultural training }\end{array}$ \\
\hline
\end{tabular}


Table 4 (Continued)

\begin{tabular}{|c|c|}
\hline Source & Summary of Relevant Findings \\
\hline $\begin{array}{l}\text { Mendenhall, } \\
\text { Dunbar, and } \\
\text { Oddou, } 1987\end{array}$ & $\begin{array}{l}\text { PART 1: SELECTION } \\
\text { Human resource departments were not looking at all the criteria that were already known to drive expatriate } \\
\text { success and failure. } \\
\text { - Selection for expatriate assignments was primarily based on technical competence, despite an increasing } \\
\text { awareness among the assigning organization of the near-equivalent importance of cross-cultural relational } \\
\text { skills. } \\
\text { - The literature already recognized that spouse and family adjustment was as critical as expatriate } \\
\text { adjustment, but only about half of companies ever interviewed the spouse. When they did, the interview } \\
\text { generally consisted of asking if the spouse was willing to relocate and support the assignee. } \\
\text { - Recommended adding the items below as additional selection criteria and measuring them through } \\
\text { testing, 360-degree (superior, peer, subordinate) evaluations, and simulated overseas work environments at } \\
\text { assessment centers. } \\
\quad \text { Self-Orientation: Stress reduction, reinforcement substitution, physical mobility, technical } \\
\quad \text { competence, dealing with alienation, dealing with isolation, realistic expectations prior to departure } \\
\text { Others-Orientation: Relationship skills, willingness to communicate, non-verbal communication, } \\
\text { respect for others, empathy for others } \\
\text { - Perceptual-Orientation: Flexible attributions, broad category width, high tolerance for ambiguity, } \\
\text { being non-judgmental, being open-minded, field-independence } \\
\text { and conducting family adaptability screening that considers existing strains on family stability and resiliency } \\
\text { and the results of breaking ties to the community. } \\
\text { - Finally, recommended planning for staffing international assignments by forecasting requirements and } \\
\text { developing a standing pool of candidates, as many of the errors in staffing are due to the urgent and reactive } \\
\text { nature of the process. Another planning deliverable during selection phase should be a repatriation plan for } \\
\text { the expatriate including duration of assignment, expected duties abroad, and expected position upon } \\
\text { repatriation. }\end{array}$ \\
\hline
\end{tabular}

\footnotetext{
${ }^{6}$ Two of the authors (Mendenhall and Oddou) first published the table in an article the year prior. In that article, they categorized expatriates and predicted their assignment performance based on which factors they were strong or weak in.
} 
Table 4 (Continued)

\begin{tabular}{|c|c|}
\hline Source & Summary of Relevant Findings \\
\hline $\begin{array}{l}\text { Mendenhall, } \\
\text { Dunbar, and } \\
\text { Oddou, } 1987\end{array}$ & $\begin{array}{l}\text { PART 2: TRAINING } \\
\text { U.S. firms underutilize cross-cultural training because they perceive it as ineffective or unnecessary, or } \\
\text { because the expatriate has no time to complete training before he begins his assignment. The training that } \\
\text { does exist is generally shallow (cognitive only) and short (a month at most), rarely includes spouses, and } \\
\text { never includes children. In-country training, if it happens, is mostly on foreign language only. To improve, } \\
\text { human resources staffs must: } \\
\text { - Calculate the financial costs of a failed expatriate assignment. } \\
\text { - Evaluate the current training program, how to improve it, and how much each improvement would cost. } \\
\text { - Communicate the information above and promote training to line and staff management } \\
\text { - Adopt more comprehensive training that reaches the trainee at the cognitive, affective, and behavioral } \\
\text { levels } \\
\text { Identify (based on length of time and degree of integration with host nation required) training } \\
\text { requirements for different expatriate positions. The author notes that some positions require more training } \\
\text { due to cultural distance and the need for culturally appropriate relational skills (e.g., negotiating with } \\
\text { possible joint venture partners in Japan) and others require more training due to the length of the } \\
\text { assignment (e.g., a multi-year tour in New Zealand). } \\
\text { Include the whole venturing family in training; adapt the curriculum and delivery for each age group }\end{array}$ \\
\hline Black, 1990 & $\begin{array}{l}\text { Study of Japanese expatriates in the U.S. determined that cultural flexibility, social orientation, willingness to } \\
\text { communicate (beyond survival needs), and a tendency to resolve conflicts collaboratively all correlated } \\
\text { directly with adjustment to the overall environment, work, and interaction with host nationals. }\end{array}$ \\
\hline
\end{tabular}


Table 4 (Continued)

\begin{tabular}{|c|c|}
\hline Source & Summary of Relevant Findings \\
\hline Gertsen, 1990 & $\begin{array}{l}\text { SELECTION } \\
\text { Points out that behavioral assessments are resource-intensive but may be a truer measure of what expatriates } \\
\text { will do than self-report surveys. } \\
\text { PREPARATION } \\
\text { - Limited candidates to choose from increases the importance of training. } \\
\text { - More than half of Danish companies surveyed (5\% early return rate) arrange a preliminary trip to inform } \\
\text { the candidate, and most of those include his family. } \\
\text { - A third ask recent repatriates from the target area to speak with the candidate. } \\
\text { - Explains the difference between: } \\
\text { O a) culture-general training that helps candidates understand how culture determines their own behavior } \\
\text { and that of others and } \\
\text { - b) culture-specific training focused on the target area } \\
\text { Asserts necessity of both, as well as the need for cognitive, affective, and especially behavioral training }\end{array}$ \\
\hline McDonald, 1993 & $\begin{array}{l}\text { SELECTION } \\
\text { Recommends thorough assessment of candidates and their families, include traits, motivation, limiting } \\
\text { circumstances, and past cross-cultural experiences. } \\
\text { PREPARATION } \\
\text { Recommends planning sufficient time between decision and departure to allow for training and practical } \\
\text { preparation. Train the whole family. Provide information on the location that will foster accurate } \\
\text { expectations. Consult other expatriates and repatriates. Use three stages of orientation, increasing in depth } \\
\text { and specificity, covering cultural, practical, and job-specific considerations, in addition to more extensive } \\
\text { cultural training. Include expatriation-specific financial counseling and a firm date for return . Assign a } \\
\text { home mentor/liaison to facilitate communication and keep the expatriate abreast of events in the home office. }\end{array}$ \\
\hline
\end{tabular}


Table 4 (Continued)

\begin{tabular}{|c|c|}
\hline Source & Summary of Relevant Findings \\
\hline $\begin{array}{l}\text { Arthur \& Bennett, } \\
1995\end{array}$ & $\begin{array}{l}\text { Responses from a large and diverse sample of international assignees contended the factors driving success } \\
\text { (from most to least important) were: } \\
\text { - Family Situation } \\
\text { - Flexibility/Adaptability } \\
\text { - } \text { - Reb Knowledge and Motivation } \\
\text { - Extra-Cultural Openness. } \\
\text { There are legal and ethical limits to how the employer can consider family situation in selection, although } \\
\text { they should always offer the family training and support. }\end{array}$ \\
\hline Wright et al., 1996 & A brief, but handy, end-to-end guide for assigning personnel overseas based on a systems approach \\
\hline $\begin{array}{l}\text { Jordan \& } \\
\text { Cartwright, } 1998\end{array}$ & $\begin{array}{l}\text { Distinguished stable personality factors and core behavioral competencies as predictors for selection. } \\
\text { Excluding factors also used in domestic selection (such as leadership ability or job knowledge), seven factors } \\
\text { were important for selecting expatriates } \\
\text { - Three personality attributes } \\
\text { O Low neuroticism } \\
\text { O Moderate extroversion } \\
\text { O High openness to experience } \\
\text { Four core competencies } \\
\text { O Relational ability } \\
\text { O Cultural sensitivity } \\
\text { Linguistic skill } \\
\text { O Ability to handle stress } \\
\text { Acknowledged the importance of non-personal factors such as family situation and career path. }\end{array}$ \\
\hline $\begin{array}{l}\text { Barker \& Cobb, } \\
1999\end{array}$ & $\begin{array}{l}\text { Recommends ethical training for expatriate managers to help them deal with dilemmas arising from } \\
\text { conflicting cultural values }\end{array}$ \\
\hline
\end{tabular}

\footnotetext{
${ }^{7}$ Obviously, the candidate herself is under no such restriction. This again highlights the importance of ensuring accurate expectations and providing the candidate the ability to self-select out of overseas assignment, ideally with no negative career consequences.
} 
Table 4 (Continued)

\begin{tabular}{|c|c|}
\hline Source & Summary of Relevant Findings \\
\hline $\begin{array}{l}\text { Harris \& Brewster, } \\
1999\end{array}$ & $\begin{array}{l}\text { Cited a book by Nicola Phillips that described expatriate managers as "involved in a wider range of activities, } \\
\text { roles and responsibilities than those required in the home market," requiring a "higher level of skills and } \\
\text { qualities" than those "operating in a less complex environment." Despite this, selection processes for } \\
\text { international assignments were often less consistent, less open, and far less formal than the academic } \\
\text { literature prescribed. Expert-recommended criteria are often not known, much less considered. Suggested } \\
\text { that at the least formal and open model end of the spectrum, the process could be driven by an impromptu } \\
\text { conversation on staffing at the coffee machine. In that model: } \\
\text { - Aware of the risk involved in international assignments but ignorant of the diverse criteria, organizations } \\
\text { may be doubling down on technical proficiency qualification } \\
\text { - Each selector will have his own list of criteria. The lists will be inconsistent and possibly contradictory. } \\
\text { - The closed process limits candidates to those the selectors know. That pool includes those who have the } \\
\text { most in common with the selectors (so probably few women and other minorities) and those who fit in } \\
\text { best with the organizational norms at the home office. This may exclude those potentially most effective } \\
\text { overseas. } \\
\text { The candidate is often identified and assumed to be selected before the process begins. The purpose of } \\
\text { the process then becomes a search for disqualifying factors, and failing that, negotiation of terms. The } \\
\text { candidate's family is not involved at the beginning and are far less likely to receive due consideration. } \\
\text { The selectors are often reacting to fill a staffing gap. The urgent, ad hoc nature of the process discourages } \\
\text { strategic consideration of the individual's career path or the long-term interests of the company. }\end{array}$ \\
\hline $\begin{array}{l}\text { Porter \& Tansky, } \\
1999\end{array}$ & $\begin{array}{l}\text { Cites previous research establishing the concept of a "learning orientation" a belief that traits are malleable } \\
\text { and performance can be improved, so that poor performance is seen as a learning opportunity. Asserts that } \\
\text { the learning orientation of prospective expatriates and their families can and should be assessed and } \\
\text { developed, because expatriate and repatriate adjustment and performance are improved by a willingness to try } \\
\text { and learn from new strategies. }\end{array}$ \\
\hline
\end{tabular}


Table 4 (Continued)

\begin{tabular}{|c|c|}
\hline Source & Summary of Relevant Findings \\
\hline Caligiuri, 2000 & $\begin{array}{l}\text { The "Big Five" are personality factors psychosocial researchers often use to classify personalities and } \\
\text { expatriate performance - specifically, Extroversion, Agreeableness, Conscientiousness, Emotional Stability, } \\
\text { and Openness or Intellect. Caligiuri measured expatriate performance by considering supervisor evaluation } \\
\text { and the expatriate's desire to prematurely terminate the assignment. Extroversion, Agreeableness, and (to a } \\
\text { lesser degree) Emotional Stability were negatively related to expatriates' desire to terminate the assignment. } \\
\text { Conscientiousness was positively related to the supervisor's evaluation of the expatriate's performance. As } \\
\text { with evaluation of family members above, employer-sponsored personality tests may be less problematic as a } \\
\text { component of self-selection than of employer selection. However, such tests, which include some inelastic } \\
\text { personality traits, may help determine who is likely to benefit most from cross-cultural training. }\end{array}$ \\
\hline $\begin{array}{l}\text { Mendenhall \& } \\
\text { Stahl, } 2000\end{array}$ & $\begin{array}{l}\text { Advocates strongly for: } \\
\text { - In-country training and continued access to coaching/mentoring throughout the assignment } \\
\text { - Development of a "global mindset" throughout a multinational organization, and making use of } \\
\text { repatriates, expatriates from the subsidiaries at the headquarters, and intercultural assessment centers to do } \\
\text { so } \\
\text { O Use of repatriates as training resources also assists in repatriates' adjustment. } \\
\text { Use of intercultural assessment centers can help develop a pool of qualified candidates for expatriate } \\
\text { assignments. } \\
\text { - Use of computer-based training and internet sites focused on life as an expatriate as cost-effective } \\
\text { supplements to in-person training }\end{array}$ \\
\hline
\end{tabular}


Table 4 (Continued)

\begin{tabular}{|l|l} 
Source & Summary of Relevant Findings \\
Novicevic, 2001 & $\begin{array}{l}\text { As the economy continues to globalize, the knowledge transfer and organizational development roles of } \\
\text { expatriates become increasingly important, but organizations are doing a poor job of sending and returning } \\
\text { effective expatriates to inform their global strategy. The authors prescribe a theory-based, multi- step } \\
\text { selection model that measures: }\end{array}$ \\
- Candidates' learning style, thinking style, and eight different types of IQ \\
- Assignment's types of tasks, difficulty of tasks, and context (especially cultural distance) \\
$\begin{array}{l}\text { The authors provide little guidance on how to match the data on the person and the job, and the collection and } \\
\text { databasing seems daunting and invasive. They also recommend: } \\
\text { Consideration of family situations } \\
\text { - Repatriation planning } \\
\text { Plan should be complete before assignment begins, and include: } \\
\text { - End date for the assignment } \\
\text { - Readjustment considerations } \\
\text { - Pre-identified position for the repatriate } \\
\text { Effects } \\
\text { - Reduces stress of uncertainty } \\
\text { - Promotes successful re-entry for expatriate and family and thus, retention } \\
\text { - Improves the chances of effective succession planning }\end{array}$
\end{tabular}


Table 4 (Continued)

\begin{tabular}{|c|c|}
\hline Source & Summary of Relevant Findings \\
\hline $\begin{array}{l}\text { Collings et al., } \\
2007\end{array}$ & $\begin{array}{l}\text { Changes in the business environment are making expatriate selection even more difficult. } \\
\text { Emerging markets and the internationalization of small and medium-sized enterprises is increasing } \\
\text { demand for assigned expatriates. } \\
\text { Supply is decreasing. } \\
\text { Individuals and firms are increasingly aware of expatriation's problems. } \\
\text { - High cost } \\
\text { - Lack of support from the home office } \\
\text { - Poor career path planning } \\
\text { - Lack of visibility in the home office } \\
\text { - Eow retention of repatriates } \\
\text { New factors hinder recruitment. } \\
\text { - Increased priority on a stable home and schooling environment for children } \\
\text { - Increase in working women } \\
\text { - Creates dual career couples who do not want to expatriate } \\
\text { - Increases the proportion of female candidates, which many organizations are reluctant to send, } \\
\text { Organizations are therefore exploring expatriate substitutes, such as short-term assignments, } \\
\text { "flexpatriates" who come and go, and global virtual teams. } \\
\text { - The substitutes fail to resolve some challenges, such as selection and training. } \\
\text { - Can exacerbate others; e.g., costs for flexpatriates are quite high } \\
\text { - Also create new challenges - for flexpatriates, the negative effects of continual travel on the } \\
\text { employee and his family; for virtual teams, difficulty in team building; for short term assignees, } \\
\text { reduced performance due to constant learning curve (includes some analysis by this author) } \\
\text { Finding alternatives to traditional expatriation does not obviate the need to effectively manage international } \\
\text { workers. One can do expatriation differently, but it still must be done correctly. }\end{array}$ \\
\hline
\end{tabular}


Table 4 (Continued)

\begin{tabular}{|c|c|}
\hline Source & Summary of Relevant Findings \\
\hline $\begin{array}{l}\text { Caligiuri et al., } \\
2009\end{array}$ & 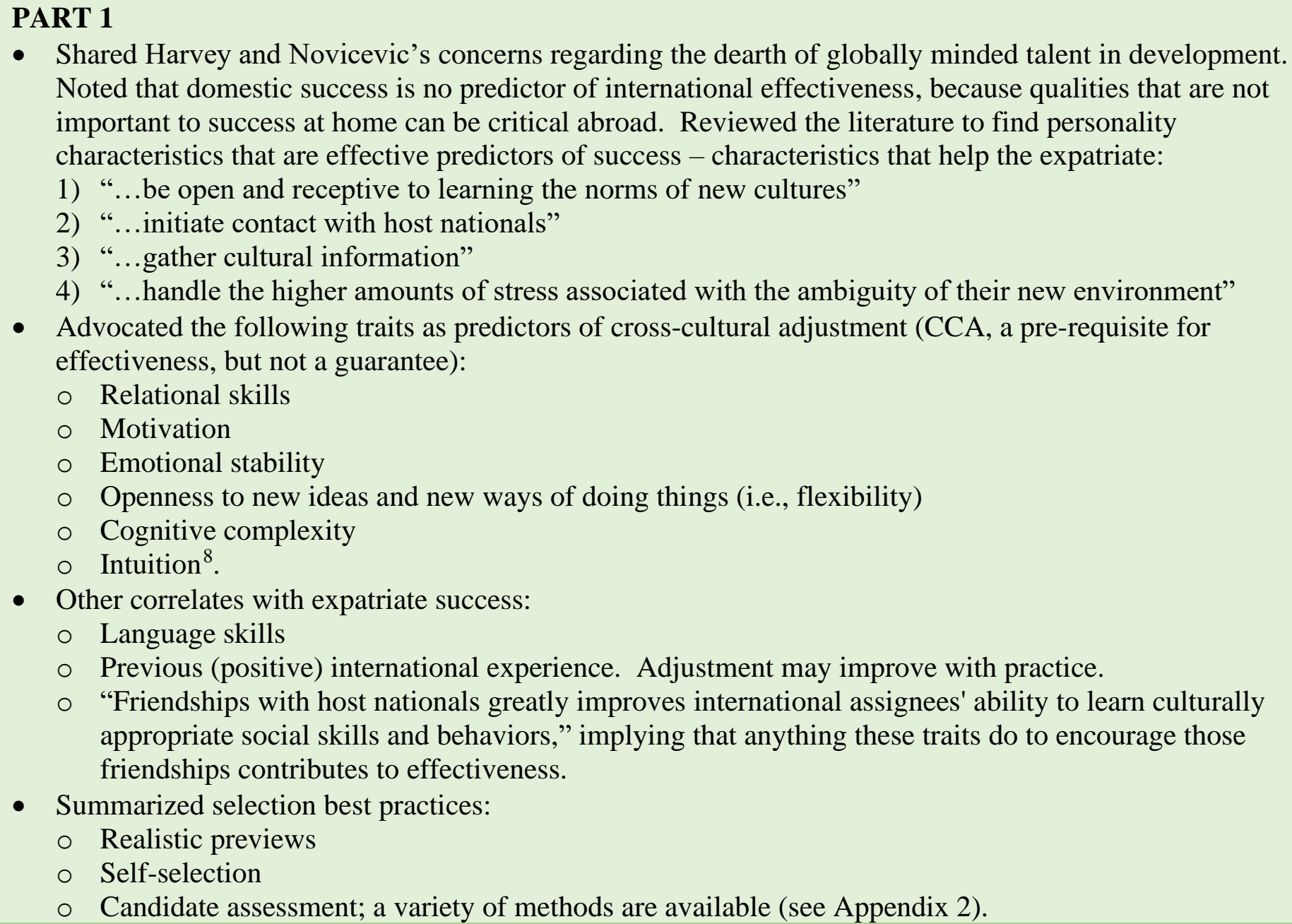 \\
\hline
\end{tabular}

\footnotetext{
${ }^{8}$ Cognitive complexity and intuition have to do with perceiving and processing (respectively) input from one's surroundings.
} 
Table 4 (Continued)

\begin{tabular}{|c|c|}
\hline Source & Summary of Relevant Findings \\
\hline $\begin{array}{l}\text { Caligiuri et al., } \\
2009\end{array}$ & $\begin{array}{l}\text { PART } 2 \\
\text { - Newer, but promising recommendations in the literature: } \\
\text { O Engaging the employee early regarding the possibility of international assignment, long before such } \\
\text { an assignment would occur; allows the employee time to process the idea and build efficacy } \\
\text { - Involving the family in the selection process as early as possible } \\
\text { Non-work predictors: } \\
\text { - Family readiness - although given privacy concerns, may be better to empower the candidate and } \\
\text { family self-assessment than assess as an organization } \\
\text { Previous work with other cultures - living or travelling abroad or exposure within one's own family. } \\
\text { Again, experience perceiving, processing, and adapting to cultural differences seems very valuable. } \\
\text { Factors which predict that pre-assignment training and the assignment itself will successfully develop the } \\
\text { assignee's international skills (often an organizational goal): } \\
\text { Conscientiousness, extroversion, openness, agreeableness, and motivation to learn all support } \\
\text { "acquisition, retention, and reproduction of learned capabilities." } \\
\text { Candidates whose extroversion drives them to spend more time with host nationals will naturally learn more } \\
\text { in the assignment. }\end{array}$ \\
\hline $\begin{array}{l}\text { Okpara \& } \\
\text { Kabongo, } 2011\end{array}$ & $\begin{array}{l}\text { Assessing Western expatriates in Nigeria, all cross-cultural training related directly to adjustment (as did prior } \\
\text { international experience), but experimental (i.e., participatory/experiential) training focused on the Nigerian } \\
\text { culture had the strongest correlation. }\end{array}$ \\
\hline Ramalu et al., 2012 & $\begin{array}{l}\text { From sampling } 332 \text { expatriates in Malaysia, cultural intelligence enables people to adjust better and promotes } \\
\text { interaction with the culture and host country nationals, therefore promoting higher job performance. }\end{array}$ \\
\hline Min et al., 2013 & $\begin{array}{l}\text { "When an expatriate manager perceives that his/her company's investment in expatriate training (PCTI, } \\
\text { perceived corporate training investment) exceeds industry standards, it leads to enhanced work adjustment" } \\
\text { and general adjustment. "A firm's organizational learning climate mediates the relationship." Therefore, } \\
\text { "Firms should not only invest in expatriate training, but should also communicate to their expatriates the } \\
\text { extent and importance that they assign to investment in training." }\end{array}$ \\
\hline
\end{tabular}


Table 4 (Continued)

\begin{tabular}{|c|c|}
\hline Source & Summary of Relevant Findings \\
\hline Bhatti et al., 2013 & $\begin{array}{l}\text { From sampling } 201 \text { expatriates in Malaysia, these traits promote job performance: } \\
\text { - } \quad \text { Previous international experience } \\
\text { - Self-efficacy } \\
\text { - } \quad \text { Social network } \\
\text { - } \quad \text { Cultural sensitivity (mediated through expatriate adjustment) }\end{array}$ \\
\hline Moon et al., 2013 & $\begin{array}{l}\text { 1. "Previous international nonwork experience is more important for developing expatriates' CQ [cultural } \\
\text { intelligence] than international work experience." } \\
\text { 2. "Predeparture cross-cultural training is important for the development of CQ as well as cross-cultural } \\
\text { adjustment," but the comprehensiveness of the training is more important than its duration. } \\
\text { 3. "CQ mediates the influences of previous international experiences and predeparture cross-cultural training } \\
\text { on an expatriate's cross-cultural adjustment" - especially motivational CQ. }\end{array}$ \\
\hline Feitosa et al., 2014 & $\begin{array}{l}\text { SELECTION } \\
\text { From literature, developed a simple, thorough model of expatriate selection and training, identifying the } \\
\text { following as "key variables in determining expatriate success, via learning and adjustment": } \\
\text { - Cultural intelligence (CQ) } \\
\text { - Learning goal orientation (LGO) } \\
\text { - Technical knowledge, skills, abilities, and other characteristics (KSAOs) } \\
\text { - Language skills } \\
\text { Both CQ and LGO are constructs that together encompass the qualities identified in previous research. "Via } \\
\text { learning and adjustment" means these same qualities will enable the expatriate to both a) learn well, first with } \\
\text { pre-travel training and then through the assignment, and b) adjust well, which is necessary for effectiveness. } \\
\text { TRAINING } \\
\text { Should be rigorous, include curriculum specific to host culture, and include information, demonstration, } \\
\text { practice, and feedback (IDPF) components }\end{array}$ \\
\hline $\begin{array}{l}\text { Andresen and } \\
\text { Margenfeld, } 2015\end{array}$ & $\begin{array}{l}\text { Surveyed } 273 \text { German employees. These factors contributed to an person's readiness to relocate abroad: } \\
\text { - Previous international work experience } \\
\text { - Endorsement of international relocation by others in their social circle } \\
\text { - Possession of a "boundaryless mindset," i.e., the mindset of a person who enjoys work outside the } \\
\text { boundaries of their current organization } \\
\text { o Uncertainty tolerance and a proactive personality were directly related to the boundaryless mindset. }\end{array}$ \\
\hline
\end{tabular}


Table 4 (Continued)

\begin{tabular}{|c|c|}
\hline Source & Summary of Relevant Findings \\
\hline $\begin{array}{l}\text { Caligiuri et al., } \\
2016\end{array}$ & $\begin{array}{l}\text { Surveyed expatriates and supervisors. For expatriates, cultural humility directly correlated with effectiveness } \\
\text { and ethnocentrism correlated inversely with effectiveness. } \\
\text { - Cultural humility is awareness that one's skills and methods are optimized for the home culture, creating } \\
\text { an appreciation of and willingness to learn from host national contributions. } \\
\text { O Creates a virtuous cycle, wherein the expatriates' willingness to learn encourages host nationals to } \\
\text { teach and provide support in other ways } \\
\text { - Ethnocentrism, conversely, is a belief in the inherent superiority of one's own culture. } \\
\text { O Engagement with a foreign culture makes highly ethnocentric individuals anxious, leading them to } \\
\text { avoid it. Host country nationals are equally disinclined to advise the expatriate, since they perceive } \\
\text { that their contribution will not be valued. } \\
3 \text { implications for practice: } \\
\text { - Select for low ethnocentrism/high cultural humility and encourage those tendencies during preparation } \\
\text { Teach expatriates to seek support and feedback from host nationals; assess their ability to do so } \\
\text { Encourage host country nationals to provide support and feedback; create structured opportunities for } \\
\text { them to do so. } \\
\text { May require addressing stereotypes of expatriates as seen by host country nationals (e.g., arrogant and } \\
\text { unwilling to learn) } \\
\text { May also mean "granting permission" to deviate from high power distance cultural norms }{ }^{9}\end{array}$ \\
\hline $\begin{array}{l}\text { Wang \& Varma, } \\
2017\end{array}$ & $\begin{array}{l}\text { Specific processes for managing expatriates reduced cultural distance's power to make maladjustment and } \\
\text { early return more likely. For selection, those processes included: } \\
\text { - Opportunity for self-selection } \\
\text { - Involvement of the entire family } \\
\text { - Pool of multiple candidates with the necessary technical and managerial requirements } \\
\text { - Expatriate selection strategy consistent with organization's global management strategy }\end{array}$ \\
\hline
\end{tabular}

9 ...perhaps by framing feedback as an expression of hospitality. Further thoughts: The link between cultural humility and the "openness" or "flexibility" cited in other literature seems obvious; humility enables openness to other ways of thinking and doing. Caligiuri, et al. mention research on personal humility, alluding to a link between cultural humility and personal humility that would be interesting to explore. Is cultural humility just personal humility expressed cross-culturally? Are the benefits of cultural humility the same as the benefits of personal humility, but more visible in a context where learning from others is more critical? 
Table 4 (Continued)

\begin{tabular}{|c|c|}
\hline Source & Summary of Relevant Findings \\
\hline $\begin{array}{l}\text { Salgado \& Bastida, } \\
2017\end{array}$ & $\begin{array}{l}\text { Surveyed } 108 \text { expatriate Spaniards to find positive correlates with multiple measures of performance: } \\
\text { - Expatriates' sociability } \\
\text { - Achievement } \\
\text { Cross-cultural adjustment correlated positively with language skills and mediated the other factors. } \\
\text { Cultural distance related inversely to both language skills and performance. }\end{array}$ \\
\hline $\begin{array}{l}\text { Wondwossen \& Su, } \\
2017\end{array}$ & $\begin{array}{l}\text { Alignment between an expatriate's personal cultural orientation and that of the host nation had a stronger } \\
\text { direct relationship with expatriate adjustment than did alignment between the cultural orientation of the host } \\
\text { nation and that of his home country. } \\
\text { - In other words, an expatriates' personal tendencies were more important than their national culture. } \\
\text { To measure cultural orientation (both national and personal), the researchers used scales based on the } \\
\text { dimensions identified by seminal researcher Geert Hofstede. They used a newly developed scale to measure } \\
\text { expatriate adjustment. } \\
\text { - If subsequent research confirms the validity and reliability of these measures, this could enable a } \\
\text { contingent model of selection that seeks a "best fit" between expatriate and host nation. }\end{array}$ \\
\hline
\end{tabular}


Matching the cultural orientation of the individual to the host country is an innovation that may prove powerful. Effective selection must have a high priority within the organization. It is perhaps best led by empowered, well-informed human resources professionals. Unplanned, informal processes and selectors who are not knowledgeable of the requirements are still common, though perhaps less so than 55 years ago. Where they are the rule, they ensure expatriate success is possible only as a happy accident.

\section{Part 3: Lived Experiences Abroad: Adjustment, Effectiveness, and Other Factors}

Searches in Part 4 included the keywords "experience" OR "adjustment" OR "effectiveness" OR "performance" OR "support" in addition to the set of keywords in the Protocol section. Conclusions for Part $3^{10}$

The literature on expatriate adjustment and effectiveness began by identifying the problems therein and the sources of those problems. The discussion moved on to theorizing about root causes and developing constructs for "intercultural competence" (AKA cultural intelligence, cultural agility, etc.). In the years just before and after the turn of the century, researchers increasingly collected empirical data to validate or invalidate their theories. Research paths also became deeper in some examples, broader in others, and narrower in still others.

- Broader in examples like Crocitto et al., 2005, who brought in findings from other fields of research and tested their application with expatriation

- Deeper in cases like Shaffer et al., in 1999 who looked for correlations between a wide range of moderators and antecedents, and found both confirmation of conventional wisdom and intriguing anomalies

\footnotetext{
${ }^{10}$ This section serves as a partial answer to the question in the Introduction, "What can expatriates do to accelerate their adjustment, and what behaviors can they avoid?" More material on this topic is in the Results chapter.
} 
Table 5. Part 3: Lived Experiences Abroad: Adjustment, Effectiveness, Other Factors

\begin{tabular}{|c|c|}
\hline Source & Summary of Relevant Findings \\
\hline Tung, 1982 & $\begin{array}{l}\text { Majority of U.S. firms sampled had a } 10-20 \% \text { early return rate. For the majority of Japanese and West } \\
\text { European firms, the rate was less than } 5 \% \text {. In U.S. sample, top } 7 \text { reasons for expat failure (most important } \\
\text { to least) were: } \\
\text { 1. Spouse's inability to adjust } \\
\text { 2. Expat's inability to adjust } \\
\text { 3. Other family problem } \\
\text { 4. Expat's personality or lack of maturity } \\
\text { 5. Expat's inability to cope with responsibilities of the job } \\
\text { 6. Expat's lack of technical competence } \\
\text { 7. Expat unmotivated to work abroad }\end{array}$ \\
\hline $\begin{array}{l}\text { Lee \& Larwood, } \\
1983\end{array}$ & $\begin{array}{l}\text { The researchers surveyed Korean managers in Korea, American managers in America, and American } \\
\text { managers in Korea on the importance of ten different cultural values (harmony, security, competitiveness, } \\
\text { etc.). American managers in Korea gave ratings that were between those of the two groups working in their } \\
\text { home countries, though still tilted more toward the American side. This may imply cultural adaptation by } \\
\text { the expatriate managers. } \\
\text { Interestingly, job satisfaction of the Americans working in Korea correlated most strongly with } \\
\text { "adjustment" of the five values wherein the Korean managers' rating differed the most from those in } \\
\text { America. In other words, American expatriates' accommodation of Korea's most salient cultural } \\
\text { differences correlated with their job satisfaction. }\end{array}$ \\
\hline $\begin{array}{l}\text { Mendenhall et al., } \\
1987\end{array}$ & $\begin{array}{l}\text { Sending organizations should: } \\
\text { - Establish a support network between headquarters and the host nation that includes repatriates and } \\
\text { engages the expatriate no later than the preparation phase. Said network should provide formal } \\
\text { (newsletters, memos, etc.) and informal reports on events and trends at headquarters. } \\
\text { - Continue to train and develop expatriates while they are overseas. } \\
\text { - Require expatriates to work with headquarters while on home leave to update repatriation and } \\
\text { succession planning. } \\
\text { - Collect in-house data on assignments, retention, and career development from current expatriates and } \\
\text { repatriates. }\end{array}$ \\
\hline
\end{tabular}


Table 5 (Continued)

\begin{tabular}{|l|l|}
\hline Source & Summary of Relevant Findings \\
\hline Black, 1988 & $\begin{array}{l}\text { Based on a sample of American expatriates in Japan, role discretion and previous overseas work positively } \\
\text { correlated with work adjustment, while knowledge of the host country before arrival, association with host } \\
\text { country nationals, and family adjustment all correlated positively to the expatriate's general adjustment. } \\
\text { Direction of causality (if any) was especially unclear regarding the expatriate's general adjustment and the } \\
\text { latter two factors - association with host country nationals and family adjustment. }\end{array}$ \\
\hline $\begin{array}{l}\text { Black \& Stephens, } \\
1989\end{array}$ & $\begin{array}{l}\text { Correlations, based on a survey of American expatriate couples in Pacific Rim nations: } \\
\text { - Spouse's favorable opinion of an expatriate assignment is positively related to spouse adjustment. } \\
\text { - Cultural distance is negatively related to spouse adjustment. }\end{array}$ \\
\hline Gertsen, 1990 & $\begin{array}{l}\text { - Spouse's adjustment has a strong positive relationship to expatriate adjustment. } \\
\text { - Couple's adjustment is positively related to intention to stay. }\end{array}$ \\
\hline $\begin{array}{l}\text { Outlines affective, cognitive, and behavioral/communicative aspects of intercultural competence. Notes } \\
\text { that early return is an inadequate measure of expatriate failure, as, "An expatriate may be ineffective and } \\
\text { poorly adjusted and still not return home; he might even do his company more home that way." }\end{array}$ \\
\\
$\begin{array}{l}\text { Uses Oberg's } 1960 \text { model of the stages of acculturation: } \\
\text { - Honeymoon } \\
\text { - Crisis } \\
\text { - Recovery } \\
\text { - Adjustment }\end{array}$ \\
\hline
\end{tabular}


Table 5 (Continued)

\begin{tabular}{|c|c|}
\hline Source & Summary of Relevant Findings \\
\hline $\begin{array}{l}\text { Feldman \& Thomas, } \\
1992\end{array}$ & $\begin{array}{l}\text { Surveyed expatriates to find: } \\
\text { - Expatriates who knew what job they were repatriating to had higher overall performance, intent to } \\
\text { remain, and internal motivation. } \\
\text { - Expatriates who freely chose to accept an international assignment were more likely to express intent to } \\
\text { complete the assignment. Feldman and Thomas suggest that the option to self-select out eliminates } \\
\text { many who lack intrinsic motivation to see it through, and choosing to go increases commitment. } \\
\text { - Seeing the international assignment as contributory to long-term career plans had a strong positive } \\
\text { correlation to "overall performance, relationships with host nationals, skill acquisition, intent to remain, } \\
\text { job satisfaction, and mutual influence" and a negative correlation to psychological stress. } \\
\text { - As coping mechanisms, social integration with host nationals and psychological reappraisal (mentally } \\
\text { reframing circumstances and events in a positive light) were also positively related to reduced stress } \\
\text { symptoms and positive work outcomes (relationship building, skill acquisition, job satisfaction, and } \\
\text { internal motivation). }\end{array}$ \\
\hline $\begin{array}{l}\text { Feldman \& } \\
\text { Tompson, } 1993\end{array}$ & $\begin{array}{l}\text { Compared data from expatriates, repatriates, and domestic job relocators and found no significant difference } \\
\text { between the groups regarding mean level of adjustment. Treatments and strategies correlated with } \\
\text { adjustment in one group (e.g., mentors, psychological reappraisal) generally correlated with the others, and } \\
\text { psychological withdrawal had a negative relationship with adjustment for all. } \\
\text { The only differences for the border-crossing groups were statistically significant relationships between } \\
\text { expatriate status and a) greater satisfaction with pay and b) knowledge of international business. The } \\
\text { authors credit the lack of a difference between groups to a) significant overrepresentation of domestic } \\
\text { relocators - almost two to one, as compared to expatriates and repatriates combined, b) an unusually high } \\
\text { degree of pre-departure training for the expatriates in the sample, and c) and d), scope limitations that } \\
\text { excluded job performance or contextual factors such as cultural distance. } \\
\text { One implication (which requires further research to confirm) is that extensive training may reduce the } \\
\text { effects of expatriation to something equivalent of a domestic job change. }\end{array}$ \\
\hline
\end{tabular}


Table 5 (Continued)

\begin{tabular}{|c|c|}
\hline Source & Summary of Relevant Findings \\
\hline McDonald, 1993 & $\begin{array}{l}\text { - Allow newly arrived expatriates (and family) several weeks to work out housing, school, and other } \\
\text { practical issues before beginning work. } \\
\text { - Appoint an employee (preferably peer-level) at the host location to act as sponsor/mentor for practical, } \\
\text { professional, and cultural issues. } \\
\text { - Maintain frequent communication between locations, including "newsletters, internal memos, meeting } \\
\text { minutes, and items of interest" to strengthen visibility and connections. } \\
\text { - To promote adjustment, expatriates must interact and network with host nationals; they should also find } \\
\text { substitutes for home country recreation activities. } \\
\text { - Warn expats to expect "mood swings" about the assignment. }\end{array}$ \\
\hline Shaffer et al., 1999 & $\begin{array}{l}\text { Cross-sectional, correlational study with a wealth of findings - including, but not limited to: } \\
\text { - Empirical support for Black's model of general, work, and interaction dimensions of adjustment } \\
\text { - As previously predicted, role clarity and role discretion (i.e., autonomy and authority) are positively } \\
\text { correlated with adjustment, as are logistical support and coworker support (both at home and host } \\
\text { nation); role novelty is negatively correlated. } \\
\text { - Expatriate spouse adjustment remains a significant predictor (or possibly result) of expatriate employee } \\
\text { adjustment, strengthening the case for training and organizational support of the spouse. } \\
\text { - Previous international experience and language fluency were both significant moderators of adjustment. } \\
\text { Beyond the main effects, the interesting relationships across the adjustment antecedents and moderating } \\
\text { factors (e.g., increased role conflict correlated with language fluency) are beyond the scope of this } \\
\text { dissertation, but they highlight interesting avenues for future research. }\end{array}$ \\
\hline Crocitto et al., 2005 & $\begin{array}{l}\text { - Uses prior research on learning cycles to suggest that expatriates need multiple mentors for multiple } \\
\text { phases and aspects of the expatriation process at both home and host locations } \\
\text { Argues that the benefit of mentors goes beyond promoting effectiveness in the assignment and the } \\
\text { expatriate's best interests and career objectives } \\
\text { Also promotes organizational effectiveness by facilitating knowledge transfer. }\end{array}$ \\
\hline
\end{tabular}


Table 5 (Continued)

\begin{tabular}{|c|c|}
\hline Source & Summary of Relevant Findings \\
\hline $\begin{array}{l}\text { Froese \& Peltokorpi, } \\
2011\end{array}$ & $\begin{array}{l}\text { Surveyed American expatriates in Japan. } \\
\text { - Culture distance and having a host nation supervisor both correlated inversely with expatriate job } \\
\text { satisfaction. } \\
\text { o Cultural differences make effective interaction more difficult and increase stress. } \\
\text { - Job satisfaction was higher in assigned expatriates than self-initiated expatriates - possibly due to } \\
\text { greater interaction and connection with home organization and home culture, or perhaps greater } \\
\text { compensation. } \\
\text { - Cultural empathy and expatriate age both correlated positively with job satisfaction. } \\
\text { Authors recommended: } \\
\text { - Measures to increase supportive (and even instructional) relationships between HCNs and expatriates } \\
\text { - Use of Multicultural Personality Questionnaire (MPQ) scale in selecting expatriates (see Appendix 2) } \\
\text { - Cross-cultural training of expatriates and HCNs }\end{array}$ \\
\hline Feitosa et al., 2014 & $\begin{array}{l}\text { Active support for expatriates from their employers, families, and contacts within the host culture promote } \\
\text { their adjustment. Expatriate families need support in order to provide support. }\end{array}$ \\
\hline $\begin{array}{l}\text { Salgado \& Bastida, } \\
2017\end{array}$ & $\begin{array}{l}\text { Surveyed } 108 \text { expatriate Spaniards to find perceived quality of support the expatriate received from } \\
\text { employing organization correlated positively with multiple measures of performance. } \\
\text { Cross-cultural adjustment correlated positively with language skills and mediated the other factors. }\end{array}$ \\
\hline $\begin{array}{l}\text { Wang \& Varma, } \\
2017\end{array}$ & $\begin{array}{l}\text { Based on a study of Taiwanese expatriates, use of certain expatriate performance management measures } \\
\text { significantly moderate (reduce) the well-established connection between high cultural distance and both } \\
\text { maladjustment and early return. These are essentially techniques recommended in the literature, and can be } \\
\text { categorized as follows: } \\
\text { - Selection (covered in previous table) } \\
\text { - Performance management (e.g., use of home and host nation mentors, clear objectives, opportunities for } \\
\text { repatriates to use knowledge learned while an expatriate) } \\
\text { - Host country national (HCN) interaction (e.g., involvement of HCNs in development of expatriate } \\
\text { selection criteria and training curriculum, language/cultural training for HCNs, deliberately promoting } \\
\text { interaction between expatriates and HCNs) } \\
\text { Examples are not all-inclusive. }\end{array}$ \\
\hline
\end{tabular}


Table 5 (Continued)

\begin{tabular}{|c|c|}
\hline Source & Summary of Relevant Findings \\
\hline Takeuchi et al., 2019 & $\begin{array}{l}\text { Expatriates' performance pattern (as measured by their supervisors) could be predicted based on the amount } \\
\text { and kind of experience they had. } \\
\text { - Specifically, expatriates who had some experience at the job and in the organization, but little or no } \\
\text { international work experience, would exhibit the U-curve pattern (honeymoon period, followed by a dip } \\
\text { and finally adjustment) typically discussed in the literature. } \\
\text { - Those with a great deal of international experience but little experience at the specific task or in the } \\
\text { organization follow the learning curve pattern, where their performance continually improves until a } \\
\text { leveling off point. } \\
\text { - Those with high levels of experience across all these measures tend to "hit the ground running" - } \\
\text { perform well at the beginning and continue to do so. } \\
\text { Those with low levels of experience across these measures tend to perform poorly and continue at that } \\
\text { level or even decline, as the challenge of learning a new job, a new organization, and a new way of life } \\
\text { overwhelms them. }\end{array}$ \\
\hline
\end{tabular}


- Narrower in examples like Takeuchi et al., in 2019, who studied the performance learning patterns of expatriates in their first few months and compared them against their previous work experience (both amount and kind).

It may also be noteworthy that, anecdotally, publishing with co-authors seems to have become more common, and average number of co-authors per paper seems to have increased as well. It is possible that as discovering new findings in the field becomes more difficult, studies require more data and more personnel to process it.

The summary of all this research, is that to best foster adjustment for the expatriate and his family, which in turn fosters mission effectiveness and completion of the assignment, the home office should take the following steps:

- Review their own processes and results for expatriation and repatriation, involving repatriates and current expatriates, to determine areas of strength and weakness. As much as possible, ensure that expatriate assignments allow assignees the authority to use their best judgment and make meaningful decisions about work. Provide the expatriate an accurate description and clear objectives for the assigned position. Make sure the expatriate knows what job he is repatriating to, and how his assignment abroad contributes to his long-term career development.

- Ensure that the expatriate and his spouse are truly willing volunteers for the assignment. Beginning at the preparation stage, actively support the expatriate and especially his family practically, professionally, and emotionally. Involve repatriates and their spouses in that support. Keep him and his spouse apprised of events, decisions, and trends at the home office and in the home community. Provide even more support for assignments of long duration or to places of great cultural distance from home. 
- Involve host country nationals (HCNs) in the development of expatriate selection criteria and training curriculum. Provide language and cultural training for HCNs to help them accept and work with the new expatriate, especially when the position is new or being filled by an expatriate for the first time. Engage coworkers in the host nation and encourage them to mentor and support the expatriate and his family as well. Task them to help the expatriate and family integrate socially with host country nationals, and challenge the expatriate and family to accept the help.

- Ensure a long overlap with the previous assignee, if there is one. Allow newly arrived expatriates (and family) at least two weeks to establish their household and begin adjusting to the culture before expecting them to be at work every day. Allow the expatriate a few more weeks as an observer shadowing his predecessor at work.

- For expatriates and families who are there longer than a year, arrange a long home leave that includes time to reconnect at the office, engage in knowledge transfer, and inform the ongoing discussion on the organizational strategy, the foreign office, the future of the expatriate position, and the expatriate herself. At the end of the assignment, continue to create opportunities for repatriates to use knowledge learned while an expatriate.

Finally, articles confirming intuitively obvious findings have also become increasingly common. Known colloquially as "water is wet" studies, they include that of Firth et al., in 2014, who found that "cross-cultural motivation and psychological empowerment related positively to initial levels of adjustment," and Ren et al., 2015, who discovered that negative psychological effects were amplified “when expatriates' emotional stability was low," and "thriving was a positive influence on expatriate engagement and actual retention beyond adjustment." I mention these not to criticize, because confirming the obvious is often necessary to drive action, but to 
show that returns on research in this field may be diminishing. Future opportunities will be in transferring that knowledge to practice.

\section{Part 4: Repatriation, Reintegration, and Outcomes}

Searches in Part 4 included the keywords "repatriation" OR "reintegration" OR "impact" or "outcomes" in addition to the set of keywords in the Protocol section.

\section{Conclusions for Part $4^{11}$}

Following the pattern of previous sections, the academy was relatively quick to identify problems, their costs, and potential solutions as data on repatriation became available for collection. As time went on, some researchers began to repeat what was already done, but as before, many others sought empirical evidence to prove or disprove assumptions an identify new areas for research. By this decade, researchers like Kraimer et al. (2012) were applying research from other fields to identify root causes. They were also determining some mid-term effects of expatriation upon individual careers and upon the organization - both generally positive, especially with expatriates who adjusted well. The most salient conclusions regarding repatriation follow below.

Repatriates leave their employers at almost double the rate of other employees. Each resignation results in the loss of:

- Human capital that may have cost more than a million dollars to develop (counting the expatriate assignment alone),

- A wealth of knowledge about the foreign subsidiary,

- An in-country network of key contacts, and

- A competitive advantage to a hiring competitor.

\footnotetext{
${ }^{11}$ This section serves as a partial answer to the question in the Introduction, "Why is reintegrating into the headquarters so difficult?" More material on this topic is in the Results chapter.
} 
Table 6. Part 4. Repatriation, Reintegration, and Outcomes

Source
Harvey, 1982
PART 1: Repatriates frequently have problems upon returning that have received even less attention in
multinational corporations than expatriation issues. Repatriates frequently cite challenges with personal
finances, readjustment to home culture, and reestablishment at headquarters. A worst case (but not atypical)
chain of events is as follows:
1) Headquarters scrambles to quickly fill an urgent need by assigning the employee overseas, considers the
problem solved, and largely ignores the employee for the length of the assignment. This ensures that the
end of the assignment is a surprise for headquarters and that the employer does no planning for repatriation.
2) While abroad, the expatriate is isolated from changes at headquarters, leading to a jarring re-entry.
3) Domestically, the expatriates' peers are promoted ahead of them.
4) The expatriate returns with no knowledge of whether his employer has a position for him, or if so, what
that position will be.
5) The new repatriate enters a liminal state of employment, possibly engaged in busy work while the
organization determines what to do with him.
6) Once solidified, the new position entails less responsibility, authority, and autonomy, as the repatriate
realizes he is no longer the "big fish in a little pond."
7) The repatriate becomes aware that his international experience has increased his employability and leaves
the sending firm to make more money and do more satisfying work elsewhere.


Table 6 (Continued)

\begin{tabular}{|c|c|}
\hline Source & Summary of Relevant Findings \\
\hline Harvey, 1982 & $\begin{array}{l}\text { PART 2: Harvey recommends: } \\
\text { - Planning for the entire expatriation/repatriation process, first by assessing the assignment's difficulty } \\
\text { - Establishing a control center for expat employees, as responsibility for them is often divided and unclear } \\
\text { - Assigning each expat a mentor (preferably a repatriate already known to the expat) who can keep the } \\
\text { expat connected to the home office and look for post-repatriation opportunities } \\
\text { - Educating expatriates on potential repatriation issues prior to departure, so they can prepare } \\
\text { - Counseling while in the field, preferably involving a repatriate employee and spouse } \\
\text { - A visit to the expat in the field } \\
\text { A formal repatriation assistance program that includes time for adjustment at work and home, a } \\
\text { reacquaintance with the home office, financial support }\end{array}$ \\
\hline $\begin{array}{l}\text { Gomez-Mejia \& } \\
\text { Balkin, } 1987\end{array}$ & $\begin{array}{l}\text { Through surveying a sample of American expats and spouses, determines that satisfaction with the } \\
\text { expatriate assignment ( } 82 \%) \text { far exceeds satisfaction with the repatriation process }(35 \%) \text {. } \\
\text { Many found the readjustment shock of repatriation to be worse than culture shock abroad, due to: } \\
\text { - } \quad \text { Restriction of career options (biggest dissatisfaction driver, partly because others at home had advanced) } \\
\text { - } \text { Reduced responsibility, authority, status, and prestige } \\
\text { - } \quad \text { Alienation due to changes at headquarters and in U.S. society } \\
\text { - Adjustment to reduced net income } \\
\text { Participants recommend: } \\
\text { - Planning for repatriation prior to departure, including not selling home in the U.S. } \\
\text { - Maintaining communication with home office and community } \\
\text { - More emphasis on language training, as language ability was a limiting factor during the assignment } \\
\text { - Use of repatriates to prepare expatriates for the assignment and the return } \\
\text { Authors' recommendations, based on practices in named multinationals: } \\
\text { - Written "repatriation agreement" prior to departure } \\
\text { - Employer-sponsored property management for U.S. home, while it's rented out } \\
\text { - Longer and more intensive language training } \\
\text { - Employer-sponsored extended home leave for multi-year assignments } \\
\text { - Formal counseling / support for repatriates, addressing participants' complaints and recommendations }\end{array}$ \\
\hline
\end{tabular}


Table 6 (Continued)

\begin{tabular}{|c|c|}
\hline Source & Summary of Relevant Findings \\
\hline $\begin{array}{l}\text { Mendenhall et al., } \\
1987\end{array}$ & $\begin{array}{l}\text { The data did not yet show that expatriate assignments could be correlated with any clear positive or negative } \\
\text { effect on one's career. Problems new repatriates encountered included: } \\
\text { 1. Lack of a job } \\
\text { 2. Reduced authority and autonomy } \\
\text { 3. Missed career opportunities } \\
\text { 4. Antipathy from coworkers } \\
\text { 5. Lack of clarity on end date for overseas assignment } \\
\text { 6. Readjustment difficulties } \\
\text { 7. Headquarters placed no value on and did not utilize repatriates' knowledge of overseas operation }\end{array}$ \\
\hline Harvey, 1989 & $\begin{array}{l}\text { Surveyed chiefs of international personnel to find that over } 2 / 3 \text { of employers sampled had no repatriation } \\
\text { support program. Of those that did, only } 35 \% \text { included spouses and only } 15 \% \text { included children. Neither } \\
\text { size of the company nor number of employees abroad affected the percentages. Reasons for not having a } \\
\text { program included: } \\
\text { - Lack of repatriation expertise } \\
\text { - Cost } \\
\text { - Senior management's lack of awareness that a program was necessary } \\
\text { Programs that did exist generally focused on: } \\
\text { - Career path counseling (with some attention to reentry stress and family disorientation) } \\
\text { - Practical relocation assistance (housing, etc.) } \\
\text { - Interim financial assistance } \\
\text { Those few programs for the family included: } \\
\text { - Interviews by counselors trained to identify problems } \\
\text { - Assistance from repatriate couples in re-socialization, practical tasks (e.g., house hunting) } \\
\text { - Additional time off and reduced travel for the repatriates upon return }\end{array}$ \\
\hline
\end{tabular}


Table 6 (Continued)

\begin{tabular}{|c|c|}
\hline Source & Summary of Relevant Findings \\
\hline $\begin{array}{l}\text { Black \& Gregersen, } \\
1991\end{array}$ & 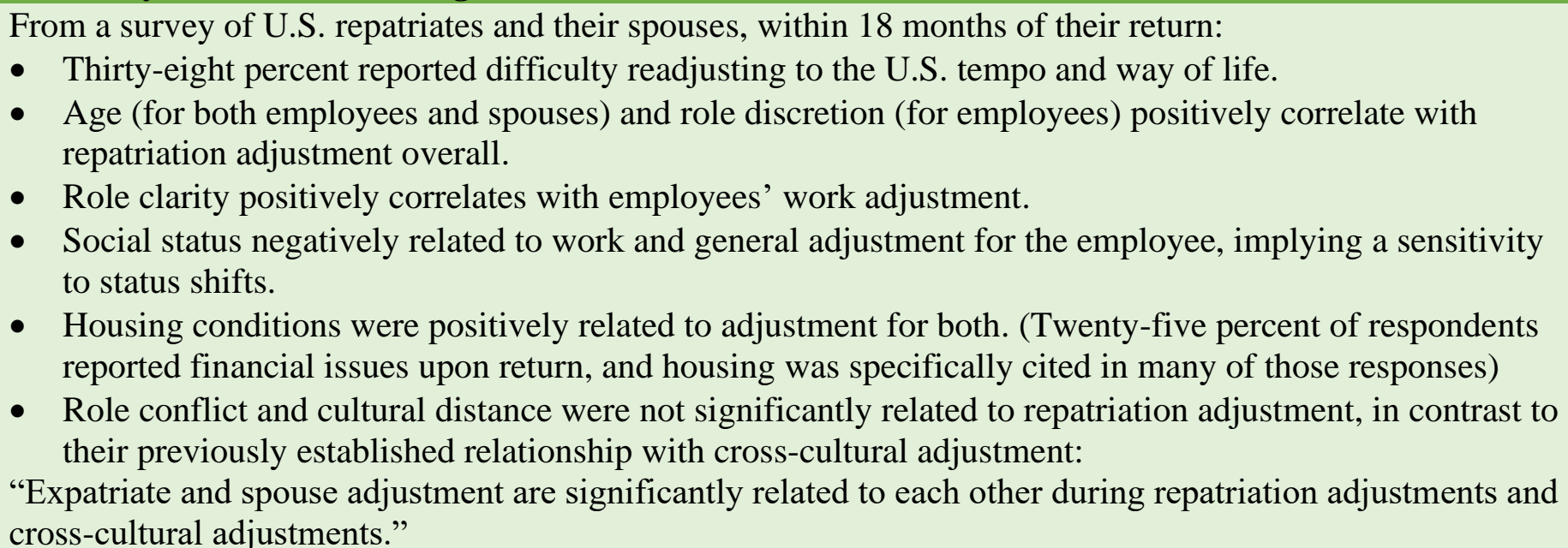 \\
\hline
\end{tabular}


Table 6 (Continued)

\begin{tabular}{|c|c|}
\hline Source & Summary of Relevant Findings \\
\hline Black, 1992 & $\begin{array}{l}\text { For repatriates in general, accurate expectations regarding work and nonwork issues led to the highest levels } \\
\text { of adjustment in all areas and to higher levels of performance on the job. Areas measured included: } \\
\text { - Job discretion (authority and autonomy to make decisions) } \\
\text { - Job constraints } \\
\text { - Job demand (volume, standards, and relational) } \\
\text { - Nonwork expectations } \\
\text { o Financial conditions } \\
\text { O Living conditions } \\
\text { O Housing condition } \\
\text { There was also a spillover effect, in that nonwork factors also correlated with job performance and the work } \\
\text { factors also correlated with adjustment measures outside of work. } \\
\text { In job measures, accurate expectations regarding job discretion generally had the strongest correlation with } \\
\text { repatriation adjustment and job performance. However, if expectations were inaccurate, it made a } \\
\text { difference whether they were overmet or undermet. If job discretion and job demand (all three categories) } \\
\text { were higher than expected, adjustment was higher than if they were lower than expected. Similarly, "as } \\
\text { expected" job discretion was best, but higher-than-expected job discretion was better than lower-than- } \\
\text { expected job discretion. } \\
\text { Unsurprisingly, findings on nonwork expectations were different. If a repatriate was paid more or had } \\
\text { better living or housing conditions than she expected, his adjustment went even better than if his } \\
\text { expectations had been met exactly. }\end{array}$ \\
\hline Black et al., 1992 & $\begin{array}{l}\text { - Notes that repatriate managers and executives leave organizations at nearly double the rate of those who } \\
\text { have stayed within the home culture } \\
\text { - Creates a theoretical framework for repatriation adjustment discussing control theory, job performance, } \\
\text { and organizational commitment } \\
\text { - Effectively incorporates and repeats guidance from other research to date } \\
\text { - Points out that some measures that may facilitate adjustment abroad - longer assignments, cost of living } \\
\text { allowances - may hinder repatriation adjustment }\end{array}$ \\
\hline
\end{tabular}


Table 6 (Continued)

\begin{tabular}{|c|c|}
\hline Source & Summary of Relevant Findings \\
\hline McDonald, 1993 & $\begin{array}{l}\text { - The expatriate and the employer must collaboratively plan for repatriation at least six months in } \\
\text { advance. } \\
\text { - Allow time for readjustment and stay engaged with the expat to support the process. } \\
\text { - Find ways to use what the expatriate has learned. Follow-up with the expatriate to make sure } \\
\text { knowledge transfer occurs regarding the assignment, the expatriation and repatriation processes, and his } \\
\text { reintegration. }\end{array}$ \\
\hline Stroh et al., 1998 & $\begin{array}{l}\text { Notes that, after an average employer cost of } \$ 1 \text { million per expatriate assignment, one-fifth to one-half of } \\
\text { returning expatriates leave their organization - a much higher rate than their colleagues. Retention is higher } \\
\text { when commitment to both the organization and the local work unit is strong, according to research. } \\
\text { Recommends employers help expatriates develop realistic expectations about their return. Repatriates: } \\
\text { - Want to use what they have learned abroad, but less than half }(39 \%) \text { get to do so } \\
\text { - Encounter resentment from colleagues upon return } \\
\text { - Encounter difficulty abroad and at home when their home office "sponsor" (official or unofficial) leaves } \\
\text { - the organization }\end{array}$ \\
\hline
\end{tabular}


Table 6 (Continued)

\begin{tabular}{|l|l|l|l}
\hline Source & Summary of Relevant Findings \\
Caligiuri, 2001 & $\begin{array}{l}\text { Hypothesized that since literature asserts that the most important factor in repatriate retention is the } \\
\text { repatriates' evaluation of their employers' repatriation process, then retention should increase when } \\
\text { repatriation problems are considered addressed. Studied 58 North American expatriates to find that career } \\
\text { path support and appreciation for international experience throughout the employing organization } \\
\text { were the most valuable components of an employer's repatriation support. Without these, repatriate } \\
\text { retention drops. The entire expatriation process can affect retention of the repatriate. } \\
\text { Recommended: } \\
\text { 1. Continual contact between the home office and the expatriates during the assignment } \\
\text { a. Long home leaves timed with home office networking activities to maintain visibility (and } \\
\text { presumably, facilitate knowledge transfer) } \\
\text { b. Inclusion of expat on company correspondence } \\
\text { c. Urging both the expat and home-based colleagues and mentors to interact with one another } \\
\text { 2. Ensure accurate expectations of both the assignment and the return. } \\
\text { a. Employ repatriates in this process. } \\
\text { b. Reduce ambiguity with a written agreement about the return. } \\
\text { 3. Begin discussing career objectives, career path, and effect of the assignment before expatriation. } \\
\text { Circulate expatriate resumes highlighting international accomplishments throughout organization prior to } \\
\text { return. } \\
\text { 4. Decrease length of assignments abroad in cases where the negative business effects will not outweigh the } \\
\text { positive effects on repatriates. } \\
\text { 5. Keep track of changes in organizational policies, personnel, and strategy, and use that information to } \\
\text { reacquaint returning expatriates. } \\
\text { 6. Allow a slow re-engagement - increased leave, reduced hours for the first few weeks after return. }\end{array}$ \\
\hline
\end{tabular}


Table 6 (Continued)

\begin{tabular}{|l|l}
\hline Source & $\begin{array}{l}\text { Summary of Relevant Findings } \\
\text { Stahl et al. 2002 }\end{array}$ \\
$\begin{array}{l}\text { Surveys hundreds of German expatriates to learn that, like their American counterparts, Germans are } \\
\text { increasingly thinking of their careers as "boundaryless." They see the same problems with repatriation in } \\
\text { their companies that the academic literature (especially in the U.S.) has described for decades. They are } \\
\text { willing to go overseas anyway, for two reasons: } \\
\text { 1. They see the experience as intrinsically valuable because it will develop them as a professional and as a } \\
\text { person. } \\
\text { 2. They know that international experience will increase their employability throughout the industry, so they } \\
\text { are not as concerned with whether their current employer values it or not. They see themselves as } \\
\text { responsible for developing their own careers, and they do not see their career advancement as connected to } \\
\text { any particular employer. }\end{array}$ \\
$\begin{array}{l}\text { The authors acknowledge that a certain amount of repatriate turnover is probably natural and acceptable, but } \\
\text { currently, repatriates leave employers at a far higher rate than their peers. The authors recommend } \\
\text { multinational employers analyze why repatriates leave their company and, as appropriate, implement their } \\
\text { recommendations (which are similar to those throughout the literature). Unless employers do so, excessive } \\
\text { turnover will continue to be something that happens to the company, a phenomenon over which it exercises } \\
\text { no planning or attempt to control. The knowledge expatriates gain at exorbitant cost to employers will } \\
\text { continue to flow freely to their competitors. }\end{array}$
\end{tabular}


Table 6 (Continued)

\begin{tabular}{|c|c|}
\hline Source & Summary of Relevant Findings \\
\hline $\begin{array}{l}\text { Lazarova \& Cerdin, } \\
2007\end{array}$ & $\begin{array}{l}\text { Studied Canadian, American, French expatriates and their companies. } \\
\text { - "The literature to date is characterized by a dearth of methodologically rigorous research determining } \\
\text { what development people achieve during their global assignments." } \\
\text { - International experience is highly sought after. } \\
\text { - } 65 \% \text { of respondents received at least one job offer while abroad, and } 60 \% \text { received at least one job } \\
\text { offer from another employer upon return. } \\
\text { - Employer support to repatriation related inversely with intent to leave. } \\
\text { - Companies on average used only a quarter of the recommended repatriate support measures. } \\
\text { - Alternate job options and actively seeking career advice or information on other employment } \\
\text { opportunities correlated positively with intent to leave. These are indicators of career activism, which is } \\
\text { believed to be stronger in modern employees who expect to manage their own career across multiple } \\
\text { employers. } \\
\text { - Authors suggested possibilities beyond traditional expatriation, including: } \\
\text { Implementing knowledge transfer measures during and immediately after the expatriate assignment } \\
\text { to ensure return on investment even if the repatriate leaves } \\
\text { B Bringing inpatriates into the headquarters from foreign subsidiaries } \\
\text { O Transferring personnel between overseas work sites } \\
\text { Using alternate forms of cross-cultural management, such as short-term assignments, and global } \\
\text { virtual teams } \\
\text { Recruiting repatriates from competitors. }\end{array}$ \\
\hline Wang et al., 2009 & $\begin{array}{l}\text { Surveyed expatriates in China to find that: } \\
\text { - Knowledge transfer to subsidiaries through expats correlated with enhanced subsidiary performance. } \\
\text { - } \quad \text { Expatriate motivation and adaptability to conduct knowledge transfer mattered. }\end{array}$ \\
\hline Kraimer et al., 2012 & $\begin{array}{l}\text { Found that expatriates tend to return home with a changed self-image - perhaps an "international employee" } \\
\text { identity, or an identity associated with roles that the employee first adopted overseas, such as a plant } \\
\text { manager role. Readjusting to the previous environment creates "identity strain," which significantly } \\
\text { correlates with turnover. According to identity theory, validating the new identity - involving the repatriate } \\
\text { in support to expatriates, using his international expertise, placing him in a position where he can exercise } \\
\text { the newly learned skills - may contribute to retention. }\end{array}$ \\
\hline
\end{tabular}


Table 6 (Continued)

\begin{tabular}{|c|c|}
\hline Source & Summary of Relevant Findings \\
\hline $\begin{array}{l}\text { Biemann \& } \\
\text { Braakmann, } 2013\end{array}$ & $\begin{array}{l}\text { Used a longitudinal study to find that professionals with international work experience in their first five } \\
\text { years after university graduation earn more and (for the male subsample) are more satisfied with their } \\
\text { careers. Lack of significant correlation between increased satisfaction and female expatriation may be due } \\
\text { to small size of the female expatriate subsample. }\end{array}$ \\
\hline Zhu et al., 2016 & $\begin{array}{l}\text { Examining } 179 \text { American expatriates, researchers found: } \\
\text { - Work adjustment often did not follow a U-shaped curve, but more often followed a steady learning } \\
\text { curve model, gradually reaching diminishing returns } \\
\text { - Previous work experience within the target culture and core self-evaluations (CSE, a construct including } \\
\text { facets of self-esteem, self-efficacy, perceived control over life events and situations, and emotional } \\
\text { stability) moderate the trajectory of the adjustment curve so that it is steeper initially } \\
\text { - CSE may also increase total capacity for adjustment } \\
\text { - A steep adjustment curve predicts expatriates' increased intent to remain with the organization, } \\
\text { increased belief that the assignment will be instrumental to their career, and increased likelihood of } \\
\text { promotion by } 1.5 \text { years after repatriation }\end{array}$ \\
\hline
\end{tabular}


Furthermore, the problems that drive turnover are visible to other employees, which discourages them from expatriating and shrinks the organization's candidate pool.

Repatriate turnover happens for two reasons. First, the repatriate's international experience significantly increases his marketability, creating lucrative and challenging opportunities. Second, repatriates often experience problems upon their return that decrease their commitment to the organization that sent them overseas. The already-low organizational commitment of generation trained to seek "protean" or "boundaryless" careers exacerbates this tendency. Common repatriation problems include the following:

- Lack of interest in, appreciation for, or utilization of the international expertise gained at great cost to both the organization and the individual. ${ }^{12}$

- Loss of autonomy, authority, status - even task variety and challenge (Birdseye \& Hill, 1995; Naumann, 1993) - upon return

- Uncertainty regarding future employment, as the employer decides whether there is a position for the repatriate, and if so, what it will be ${ }^{13}$

- The firm often places the repatriate in a temporary position while they decide these issues; that position is often lower in both status and intrinsic interest than either the overseas position or the position the repatriate left at home.

\footnotetext{
${ }^{12}$ Author's note: Excepting Kraimer, et al.'s excellent work incorporating identity theory (2012), reasons why this is so damaging are not prominently discussed in the literature. They could be a topic for future research. Combined with the other problems, lack of use of international expertise may create cognitive dissonance and a sense of loss. The company's poor return on investment may also cause the repatriate to question the judgment of the employer. Any of these effects could inspire employees to distance themselves from the sending organization.

${ }^{13}$ The uncertainty may encourage the repatriate to seek outside employment as a way of regaining control.
} 
- Relative deprivation -- repatriate perceptions that the organization forgot about his or her absence and moved on, while peers moved ahead in the organizational hierarchy, taking advantage of opportunities she missed ${ }^{14}$

- Changes in the repatriate, the organization, and the home culture, which combine to hinder adjustment and create a sense of alienation in the repatriate

- Loss of an organizational mentor or sponsor at any point in the expatriation cycle exacerbates this disconnect

- Difficulties regarding personal finance and housing as the repatriate returns to a reduced net income (due to loss of overseas allowances) and a changed housing market Organizations that seek to retain repatriates cannot send away expatriates and forget about them; they must actively support, manage, and communicate with them. Not enough companies have a formal repatriation support program, and those programs that do exist often omit critical elements. But Stephen Covey's dictum to "begin with the end in mind" can summarize many of the methods to prevent or mitigate the common repatriation issues listed above.

BEFORE LEAVING, the expatriate employee and family should know:

- What to expect regarding work and nonwork issues not only during the assignment, but upon return

○ This should include problems repatriates often encounter and how they and the organization can work to prevent them, because the cost of repatriate turnover exceeds the cost of self-selection out.

\footnotetext{
${ }^{14}$ Repatriates may look at outside opportunities as a way of "catching up" to the peers they left behind.
} 
- Who their mentors are; how and when they will communicate with them; and how their mentors' training, experience, and current position will help them before, during, and after the assignment

- Availability of formal counseling before, during, and after ${ }^{15}$

- The expatriate's first job upon return, how it will make use of his international experience, and how both positions will support the employee's and the organization's long term goals

- A clear end date for the assignment

- A plan for housing upon return, which may require employer support (e.g., sponsoring rental property management during the assignment)

- Total compensation before and after the assignment abroad, as well as expected cost of living breakdowns for both locations

DURING THE ASSIGNMENT, the employer should keep expatriates informed and engaged in the happenings at headquarters that should involve correspondence and visits back to headquarters timed to exploit conferences, retreats, or other networking and knowledge transfer opportunities. They should also ensure the expatriate is transferring what he is learning back to headquarters and then disseminate that knowledge (with resulting tasks) as appropriate. The mentors should be a key part of the two-way knowledge transfer. This communication maximizes the expatriate's benefit to the organization during the assignment. It also greatly mitigates the cost if she decides to resign after she returns. It should cover not only business operations, but also administrative, family, and logistical issues surrounding the expatriation

\footnotetext{
${ }^{15}$ Counseling is already a component of many organizations' employee assistance program. In those cases, expatriates and their families need to know how to access the counseling. Employers need to ensure that the counseling service provider is trained to help with cross-cultural, relocation, and repatriation adjustment.
} 
process, as well as updates to pre-expatriation planning. These can help the employer support the expatriate now and improve the process for future assignees.

UPON RETURN, repatriates should be allowed time off to readjust with their family. When they return, they should act as an observer for a few weeks before they formally enter their new position. In addition to using their newly gained expertise for mission purposes, they should also be involved in future expatriation and repatriation preparation and support.

\section{Conclusions for Literature Review Overall}

Expatriation and repatriation incur significant cost and risk for both the employee and the employer. Moving to a new job and moving to a new location are two of the biggest stressors people commonly experience in their lives, even when those moves are within the same overall culture. To combine those with moving one's self and one's family into an entirely different way of life and then, years later, return, is an extraordinary, life-altering event. As the literature shows us, it requires people to develop new behaviors, new skills, and new ways of thinking, even of themselves. Failure is common, and so is the cost, in both monetary and human capital. So why do it? Why not hire a local?

Regarding foreign subsidiaries, senior management wants control at minimal cost - not just in money, but in time and attention. They want to shape the subsidiary to make decisions that support the headquarters' strategy and objectives, without having to micro-manage and make those decisions themselves. They want to know everything they need to know about the foreign subsidiary without being inundated with detail, and they want employees at the foreign site to know headquarters expectations. They want to hear about good ideas that other sites can use to become more effective. They want someone who can recognize opportunities and represent the 
organization well, expanding its access and maximizing the benefit they receive from being multinational.

For the long term (i.e., post-repatriation), they want someone on the management team back at headquarters who understands the reports from the overseas office. They want someone at the home office who can answer questions about the business climate, the working conditions, the logistics, and the markets overseas - or who has a trusted friend who can. They know things are done differently in different places, but they don't always know how or why. An effective expatriation program meets those objectives. It lowers their risk, because it prevents them from thoughtlessly making decisions that kill a golden goose in some far-off land.

Assigned expatriates who are most likely to meet those objectives are flexible, emotionally stable, and handles stress well. They are genuinely excited to live in an exotic place, build relationships with people who think and work differently, and learn from them. They look at the assignment as an opportunity and an expression of trust by their employer, not as a burden they were pressured into taking on. To be effective, they need to know how to communicate effectively in the host country, and what differences to expect in both life and work. They need to have strategies to deal with those differences, a support network at home and abroad, and a realistic plan for their return that their employer also shares. Experience working abroad - either theirs, or that of mentors - is a tremendous asset. If they are bringing family, they need to be equally willing, able, and prepared to meet the challenge. If the organization and the expatriate have taken action to meet the above conditions, then they are far more likely to meet those objectives.

However, there is still more that can be done. If the organization a) continues to support the repatriates and their families through their readjustment and b) gives them opportunities to use 
what they have learned overseas for the organization's benefit, they may have a long and mutually beneficial association.

The difficulties associated with expatriate assignments and even the recommended treatments for those issues are not entirely consistent across five decades of research - across home nations, host nations, employment sectors, and occupations. However, they are remarkably so. Given that, Kraimer, Bolino, and Mead mused in 2016 that even after decades of study on challenges and solutions, "we know very little about the nature of international work itself." That lack of understanding impedes the foundational human resource functions of job analysis and design, the typical prerequisites for steering selection, training, evaluation, and compensation. The authors go so far as to say that the lack of investigation into the demands of international work may be the root cause of the impediments to expatriate selection and adaptation.

\section{Way Ahead and Research Questions}

My own review of the literature confirms that dearth of research. Phenomenology, the study of the essence of lived experiences, seems the logical research method to build a qualitative understanding of "the nature of international work." I used ABI/Inform Global to search each time period for "lived experience," "lived experiences," phenomenology," and "phenomenological" in association with the original list of key words. My searches returned a total of 21 articles with the earliest published in $2009 .{ }^{16}$ Of these, only nine were focused on the lived experiences of assigned expatriates, and two of these were based on the same study (Aquino-Russell \& Russell, 2009; Russell \& Aquino-Russell, 2010). Eight focused on expatriates in a single country (Aquino-Russell \& Russell, 2009; Baba, 2018; Jackson \& Manderscheid, 2015; Kemp \& Rickett, 2018; McKenna, 2010; Onosu, 2016; Russell \& Aquino-

\footnotetext{
${ }^{16}$ To put that in perspective, every one of my search term sets above returned hundreds of articles across the same 55-year time period.
} 
Russell, 2010; Wijerathna \& Hewapathirana, 2019 ); one was based solely on three emails from a single expatriate (McKenna, 2010). The one that included expatriates in multiple countries focused on expatriate divorce (McNulty, 2015). None systematically looked at the expatriate experience from end-to-end, from selection to repatriation, across nations and industries. None sought to find what was essential to international work across a wide range of assigned expatriate experience.

As it is, the literature depicts a pipeline the expatriate is moving through - one that has key points where the expatriate has a strong chance of being diverted from the intended path. There is much discussion of what happens within the pipeline and how to close the points of diversion. There is very little discussion from the expatriates' perspective of what they experience while moving through it.

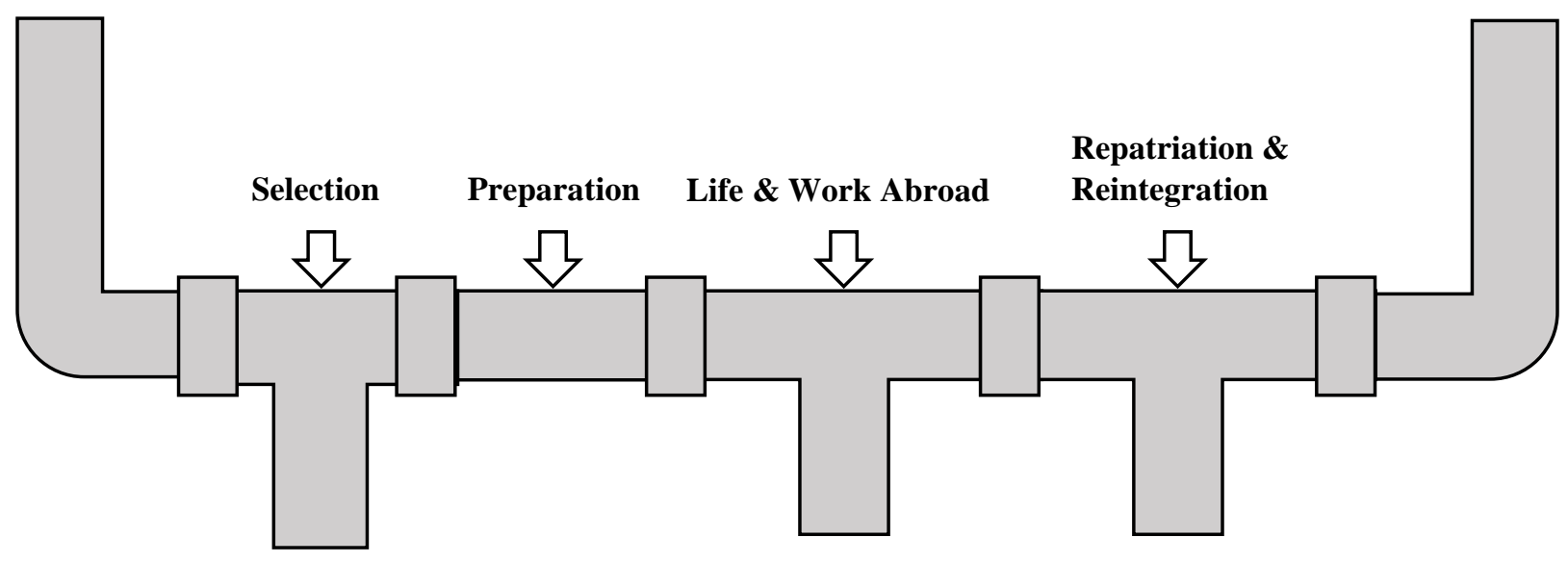

\section{Figure 1. The Expatriate Experience Pipeline}

In truth, the number of pipelines is something greater than the number of sending organizations multiplied by the number of assignment locations. In other words, there can be multiple ways to "do" expatriation even within one organization. Nevertheless, the same issues often arise within all these different paths, implying something fundamentally the same across 
the assigned expatriate experiences. These gaps in the literature leave (at least) two research questions for subsequent investigation:

RQ1. What are the distinctive characteristics of life and work as an assigned expatriate?

RQ2. How do assigned expatriates perceive their expatriate experience? 


\section{CHAPTER THREE:}

\section{METHODOLOGY}

I used a qualitative, phenomenological approach in this study. The intent was to obtain narrative details from a variety of lived experiences as an assigned expatriate, and from those, derive what was common and therefore essential. To do so, I conducted semi-structured interviews with the following 15 formal questions, asking follow-up and branching questions as the data led and time allowed.

1. The purpose of this interview is to learn about your experiences as an assigned expatriate, i.e., someone who was sent overseas for an extended period of time to do a job. Can you tell me what experiences you have had as an assigned expatriate? [Interviewer will ask follow-up questions to get time, place, employer, and position title for each experience.]

2. Now I will ask questions about each one of those experiences in turn. First, regarding your experience in , who did you bring with you?

3. Please describe how you were selected.

4. How did your organization prepare you (and if applicable, your family) for the assignment?

5. What was your expectation about this overseas assignment prior to your departure?

6. Once you got there, what were your duties?

7. Can you describe your living conditions?

8. What adjustments did you have to make regarding life and work in your host nation?

9. What were some of your most powerful or distinctive experiences there? Both positive and negative experiences count.

10. How was your experience in comparison to your expectations? What about your family's experience in comparison to their expectations?

11. Would you like to share anything else that exemplifies your experience?

12. What lessons did you learn from your experience during that assignment?

13. What was your repatriation experience like after you came back home from overseas? [If that fails to elicit much response, alternative forms of the question are as follows:] What were some of the positives and negatives of your repatriation experience? Can you describe your reintegration into your home and your organization back in the U.S.?

14. Did your overseas experience change you? If so, how? Did your family's overseas experience change them? If so, how?

15. Is there a question I should have asked that I did not? 
My interview questions were intentionally open-ended to foster free-flowing discussion of my interview subjects' experiences. The opening questions covered the characteristic details or metadata of each overseas assignments, i.e., who, where, when, doing what, etc. The findings here are covered below under the "Sample Data" heading of this methodology section. The middle questions then covered each stage of the assignment in turn - selection, preparation, life and work abroad, and finally repatriation and reintegration. The questions during the life and work abroad section were designed to draw the subject into telling salient stories about their experiences. The closing questions covered the lasting impact of those experiences and asked the subject to offer any questions the interviewer should have asked but did not. It served two purposes: It induced the subject to relate aspects of their experience that the previous questions had missed, and it helped identify areas for future research.

\section{Sample Population Criteria and Selection}

I selected participants who served at least six months abroad in an expatriate assignment, working closely with members of the host nation culture. Subjects were not required to participate. They could terminate their involvement at any time without repercussion.

To identify participants, I compiled a list of email contacts who had served in such an assignment or knew others who had and emailed a request for volunteers. Among my acquaintances and their acquaintances, I quickly had more qualified volunteers than I had time to interview.

The nature of my combination convenience / snowball sample creates natural limitations on my data. Each person who volunteered to relate their experiences as an assigned expatriate was someone who viewed his or her experience as positive. The academic literature and anecdotal evidence show that positive experiences are not universal for either the individual or the sending 
organization. It is likely that those with negative experiences are reluctant to discuss those experiences at length and record them for posterity, anonymous as they may be. Consequently, this study on the lived experiences of assigned expatriates may function as a study on how to do expatriation well.

\section{Pilot Interview}

I conducted an in-person pilot interview to see if the phenomenological research questions I had developed would yield rich, usable data. I also wanted to rehearse the interview, recording, and transcription process. My interview subject was a former military officer who had multiple overseas tours working closely with host nation personnel in combat zones and in secure environments. I interviewed the subject about two tours in South Korea, totaling three years. The first was unaccompanied, and the second was accompanied by family. South Korea is a fragile but stable peacetime environment with a first world economy and a high standard of living. I did not include the data from the pilot interview in my principal research, but I did interview the subject again regarding one of his subsequent tours overseas.

Regarding the process mechanics, my recording techniques were effective enough, but the transcription was not. I used the Otter application for transcription and found that its machine translation was too imprecise for recordings of natural speech done outside a studio environment, peppered with professional jargon, verbal pauses, repeated phrases, and most problematically, foreign language phrases. This motivated a switch to the Rev application for the full study, which was more effective.

I used essentially the same questions that I would use in the full study (see above), with the exception that I did not ask the subject to suggest additional questions (Question \#15). The questions were effective at inducing the subject to speak at length about expatriate experiences at 
a deep, experiential level. In fact, the subject's emic experiences reflected many of the findings of the last several decades of etic research. Specifically, the interview text directly addressed or alluded to the following topics regarding expatriate work:

- High role ambiguity (lack of role clarity)

- High task variety

- High autonomy (high role discretion)

- High degree of interaction with host country national $(\mathrm{HCN})$ and employer elites

- Employer's ignorance of some aspects of host country circumstances, methods, and culture $^{17}$

- Importance of flexibility on the part of the expatriate

- Necessary cultural adaptations

- Local methods

- The importance of emotional stability

- Instances of finding and creating commonalities

- The expatriate community

- A haphazard and anemic selection process

- The value of a cadre of people trained in intercultural competence and negotiation

- Functioning as a liaison

- Representing "the face" of the organization to host country partners

- Cultural adaptations of HCNs to the expatriate

- Observation and inquiry to learn how to operate in the host nation culture

${ }^{17}$ Although in this case, the employer was in the host country. 
- The inherent challenge of cross-cultural work

- Differences between expectations and reality

- Multiple bosses (role conflict)

- Repatriation adjustment

- Different living and working conditions

- Awareness of own culture

- Importance of relationships with HCNs, expatriate community, and employer

- Provocation to think more deeply about sociology, politics, and culture

- Quality of the experience

This apparent correlation served as a kind of mutual validation of both the questions and the previous literature. The subject's organic discussion of specific issues identified in previous studies indicated that the questions might effectively explore assigned expatriation. Conversely, the alignment of the subject's personal experience with completely unrelated research supported the validity of that research. In addition, since most of the previous research had studied expatriate civilians in the private sector, this alignment supported the hypothesis that there is commonality to the expatriate experience across employment sectors and other variables.

Finally, these topics and observations continued to arise throughout the principal research, so the opportunity to start thinking about them early on was invaluable.

\section{Sample Data}

I conducted 20 interviews of 19 interview subjects, covering 26 overseas assignments, in 16 locations (not counting additional side travel of less than two months in length). Seven subjects discussed two assignments each, while the rest each covered only one. One of those subjects was not able to complete the interview questions regarding the second assignment due to time. 
Three subjects also discussed long term assignments wherein they spent significant periods of time (eight weeks or more) in a secondary location. Upon completing those 20 interviews, I reached saturation of information. I had exceeded the theoretical minimum of ten interviews for phenomenological research, and I had covered a variety of different types of assignments. I was no longer finding new information regarding the lived experiences of assigned expatriates in general (Seidman, 2013) from which I could distill a common phenomenon (Creswell, 2018).

Due to the use of a convenience sample and the researcher's military background, military and civil government personnel are overrepresented among the interview subjects, and conflict zones and the developing world are overrepresented among the assignment locations. Those populations and locations have received less attention in academic business literature on expats than private sector or academic populations on non-conflict zone tours. Given those facts, the existence of commonalities among all these populations is even more striking, and it strengthens the argument that a common phenomenon exists across these widely varying experiences.

\section{Anticipated Benefit of the Study}

As the literature review showed, the academic community began studying the assigned expatriate phenomenon and the issues surrounding it decades ago, and that study has been extensive. Nevertheless, gaps and shortfalls in that collective knowledge persist (Kraimer et al., 2016; Shaffer et al., 2012; Chiang et al., 2018). This study will attempt to address three of them.

First, as researchers look for new things to learn in this field, the trend has been to make the research increasingly atomistic in both the stage of the expatriate phenomenon and the population studied. This is logical, in that a narrow study can have more depth and perhaps reach more definitive conclusions. However, such self-restriction reduces applicability to practice. It also precludes findings that cross stages and communities within the expatriate 
experience (Chiang et al., 2018). I was not able to find any research in this century that looked at the expatriate experience from selection through to repatriation, nor have I found any research that looks at expatriates from the private sector, civil government, and the military simultaneously. This study does both.

Second, the overwhelming majority of the academic literature looks at expatriation from an etic perspective. There is comparatively little discussion of the expatriation as the expatriate experiences it. As a methodology, phenomenology is an etic analysis of the emic perspective, and thus a major step in that direction. However, as noted in the literature review, I was not able to find phenomenological research of assigned expatriates prior to 2009, and the research since 2009 is both sparse and narrowly focused. Again, this study addresses that gap.

\section{Principal Research}

Prior to the interviews, I submitted a social-behavioral study protocol, an informed consent script, and interview questions to the University of South Florida (USF) for Institutional Review Board (IRB) approval using the University’s BullsIRB and Applications for Research

Compliance (ARC) systems. At the beginning of my first interview with each subject (and while recording), I read aloud the script of a USF approved Informed Consent form. The interview subject had ample time to listen and fully appreciate what they were consenting to. Each interview subject verbally consented on audio record. The audio and video files are located at https://usf.app.box.com. Access is limited to those permitted by USF IRB. I conducted each interview alone. Interview data on https://usf.app.box.com is encrypted and will be maintained there for five years. No interview subjects were members of potentially vulnerable populations, such as children, prisoners, the cognitively impaired, institutionalized, or critically/terminally ill. 
Table 7. Sample Data

\begin{tabular}{|c|c|c|c|c|c|c|c|c|c|c|}
\hline Trip & $\begin{array}{l}\text { Location ( } \geq 2 \\
\text { months) }\end{array}$ & $\begin{array}{l}\text { Interview } \\
\text { Subject }\end{array}$ & Sex & $\begin{array}{l}\text { Occupation } \\
\text { Type }\end{array}$ & Employer & $\begin{array}{l}\text { Conflict } \\
\text { Zone }\end{array}$ & Accompanied & Volunteer & $\begin{array}{l}\text { HDI } \\
\text { Rank as } \\
\text { of } 2020\end{array}$ & $\begin{array}{l}\text { Time } \\
\text { overseas } \\
\text { (years) }\end{array}$ \\
\hline A & Afghanistan & 01 & $M$ & military & $\begin{array}{l}\text { U.S. armed } \\
\text { forces }\end{array}$ & Yes & No & Yes & 170 & 1 \\
\hline B & Afghanistan & 02 & $\mathrm{~F}$ & military & USDA & Yes & No & Yes & 170 & 1 \\
\hline C & Afghanistan & 03 & $M$ & $\begin{array}{c}\text { civil } \\
\text { government }\end{array}$ & USAID & Yes & No & Yes & 170 & 3 \\
\hline $\mathrm{D}$ & Mali & 04 & $M$ & military & $\begin{array}{l}\text { U.S. armed } \\
\text { forces }\end{array}$ & Yes & No & Yes & 184 & 1 \\
\hline $\mathrm{E}$ & Iraq & 05 & $\mathrm{M}$ & military & $\begin{array}{l}\text { U.S. armed } \\
\text { forces }\end{array}$ & Yes & No & No & 120 & 0.75 \\
\hline $\mathrm{F}$ & Afghanistan & 06 & $M$ & military & $\begin{array}{l}\text { U.S. armed } \\
\text { forces }\end{array}$ & Yes & No & Yes & 170 & 0.75 \\
\hline G & Tajikistan & 07 & $M$ & $\begin{array}{c}\text { civil } \\
\text { government }\end{array}$ & $\begin{array}{c}\text { Department } \\
\text { of State }\end{array}$ & No & No & Yes & 125 & 2 \\
\hline $\mathrm{H}$ & Iraq & 08 & $M$ & military & $\begin{array}{l}\text { U.S. armed } \\
\text { forces }\end{array}$ & Yes & No & No & 120 & 0.6 \\
\hline 1 & Afghanistan & 08 & $\mathrm{M}$ & military & $\begin{array}{l}\text { U.S. armed } \\
\text { forces }\end{array}$ & Yes & No & Yes & 170 & 1 \\
\hline J & Italy & 09 & $\mathrm{~F}$ & student & university & No & No & Yes & 29 & 0.85 \\
\hline $\mathrm{J}$ - side trip & $\begin{array}{c}\text { Bosnia- } \\
\text { Herzegovina }\end{array}$ & 09 & $\mathrm{~F}$ & coach & $\begin{array}{l}\text { athletic } \\
\text { team }\end{array}$ & Yes & Yes & Yes & 75 & 0.3 \\
\hline $\mathrm{K}$ & Mozambique & 10 & $M$ & $\begin{array}{c}\text { civil } \\
\text { government }\end{array}$ & $\begin{array}{l}\text { Peace } \\
\text { Corps }\end{array}$ & No & No & Yes & 170 & 2 \\
\hline
\end{tabular}


Table 7 (Continued)

\begin{tabular}{|c|c|c|c|c|c|c|c|c|c|c|}
\hline Trip & $\begin{array}{l}\text { Location ( } \geq 2 \\
\text { months) }\end{array}$ & $\begin{array}{l}\text { Interview } \\
\text { Subject }\end{array}$ & Sex & $\begin{array}{l}\text { Occupation } \\
\text { Type }\end{array}$ & Employer & $\begin{array}{l}\text { Conflict } \\
\text { Zone }\end{array}$ & Accompanied & Volunteer & $\begin{array}{l}\text { HDI } \\
\text { Rank as } \\
\text { of } 2020\end{array}$ & $\begin{array}{l}\text { Time } \\
\text { overseas } \\
\text { (years) }\end{array}$ \\
\hline $\mathrm{L}$ & Afghanistan & 10 & $\mathrm{M}$ & $\begin{array}{l}\text { private } \\
\text { sector }\end{array}$ & $\begin{array}{c}\text { defense } \\
\text { contractor }\end{array}$ & Yes & No & Yes & 180 & 3 \\
\hline $\mathrm{M}$ & South Korea & 11 & M & military & $\begin{array}{l}\text { U.S. armed } \\
\text { forces }\end{array}$ & No & Yes & No & 22 & 2.5 \\
\hline $\mathrm{N}$ & Germany & 12 & $M$ & military & $\begin{array}{l}\text { U.S. armed } \\
\text { forces }\end{array}$ & No & No & Yes & 4 & 2 \\
\hline 0 & Gambia & 13 & $\mathrm{~F}$ & $\begin{array}{c}\text { civil } \\
\text { government }\end{array}$ & $\begin{array}{l}\text { Peace } \\
\text { Corps }\end{array}$ & No & No & Yes & 170 & 2 \\
\hline $\mathrm{P}$ & Afghanistan & 13 & $\mathrm{~F}$ & $\begin{array}{c}\text { civil } \\
\text { government }\end{array}$ & USAID & Yes & No & Yes & 180 & 1.85 \\
\hline Q & Iraq & 14 & M & military & $\begin{array}{l}\text { U.S. armed } \\
\text { forces }\end{array}$ & Yes & No & No & 120 & 1 \\
\hline $\mathrm{R}$ & Mauritania & 14 & $\mathrm{M}$ & military & $\begin{array}{l}\text { U.S. armed } \\
\text { forces }\end{array}$ & No & No & Yes & 161 & 1 \\
\hline $\mathrm{S}$ & Mexico & 15 & $\mathrm{M}$ & $\begin{array}{l}\text { private } \\
\text { sector }\end{array}$ & $\begin{array}{l}\text { private } \\
\text { sector }\end{array}$ & No & No & Yes & 76 & 2.5 \\
\hline $\mathrm{T}$ & Mexico & 15 & $\mathrm{M}$ & $\begin{array}{l}\text { private } \\
\text { sector }\end{array}$ & $\begin{array}{l}\text { private } \\
\text { sector }\end{array}$ & No & Yes & Yes & 76 & 3 \\
\hline$U$ & Afghanistan & 16 & $M$ & military & $\begin{array}{l}\text { U.S. armed } \\
\text { forces }\end{array}$ & Yes & No & Yes & 170 & 1 \\
\hline V & $\begin{array}{l}\text { United } \\
\text { Kingdom }\end{array}$ & 17 & $\mathrm{M}$ & military & $\begin{array}{l}\text { U.S. armed } \\
\text { forces }\end{array}$ & No & No & Yes & 15 & 2 \\
\hline $\mathrm{V}$ - side trip & Morocco & 17 & $M$ & military & $\begin{array}{l}\text { U.S. armed } \\
\text { forces }\end{array}$ & No & No & Yes & 22 & 0.15 \\
\hline
\end{tabular}


Table 7 (Continued)

\begin{tabular}{|c|c|c|c|c|c|c|c|c|c|c|}
\hline Trip & $\begin{array}{l}\text { Location } \\
\text { ( } \geq 2 \\
\text { months) }\end{array}$ & $\begin{array}{l}\text { Interview } \\
\text { Subject }\end{array}$ & $\operatorname{Sex}$ & Occupation Type & Employer & $\begin{array}{l}\text { Conflict } \\
\text { Zone }\end{array}$ & Accompanied & Volunteer & $\begin{array}{l}\text { HDI } \\
\text { Rank } \\
\text { as of } \\
2020\end{array}$ & $\begin{array}{l}\text { Time } \\
\text { overseas } \\
\text { (years) }\end{array}$ \\
\hline W & Israel & 17 & $M$ & military & $\begin{array}{c}\text { U.S. } \\
\text { armed } \\
\text { forces }\end{array}$ & No & Yes & Yes & 121 & 3 \\
\hline$x$ & $\begin{array}{c}\text { Former } \\
\text { Yugoslavia }\end{array}$ & 18 & $\mathrm{M}$ & private sector & $\begin{array}{l}\text { private } \\
\text { sector }\end{array}$ & Yes & No & Yes & 63 & 2.75 \\
\hline $\mathrm{Y}$ & Cambodia & 18 & $\mathrm{M}$ & $\begin{array}{c}\text { intergovernmental } \\
\text { organization }\end{array}$ & $\begin{array}{l}\text { United } \\
\text { Nations }\end{array}$ & No & Yes & Yes & 146 & 1 \\
\hline \multirow[t]{3}{*}{ Z } & Japan & 19 & $\mathrm{~F}$ & private sector & $\begin{array}{l}\text { private } \\
\text { sector }\end{array}$ & No & No & Yes & 19 & 1 \\
\hline & & & & & & & & & $\begin{array}{l}\text { total } \\
\text { years }\end{array}$ & 44 \\
\hline & & & & & & & & & mean & 1.571429 \\
\hline
\end{tabular}


Interview duration ranged from 34 minutes to 116 minutes, for an average 71 minutes per interview. Due to the COVID-19 pandemic of 2020, no interviews were in person, with the exception of a pilot interview prior to initiation of the study. I used telecommunication applications (Zoom and Rev) over the telephone or on a computer to conduct and record each interview. I used the Rev service for transcription. I analyzed the data using the in vivo coding method to identify themes and code blocks of text using theme descriptors. To code the text, I used the application NVivo. Excerpts from interview transcripts that serve as exemplars for points made in the next chapter are referenced within the text using lower case, superscript Roman numerals, and included in Appendix 1. 


\section{CHAPTER FOUR:}

\section{RESULTS}

For the data gleaned from interviews for this study, there are two natural organization schemas. The first is the chronological structure of the interview questions themselves. The second is the organization of the themes which emerged during coding. An overview of this schema is shown in Table 8 on the following two pages. The analysis of the data will follow a hybrid of the two schemes, with the chronological scheme as the four-part overarching structure and the emergent scheme serving as the framework within those four stages. 
Table 8. Themes from Phenomenological Interviews of Assigned Expatriates

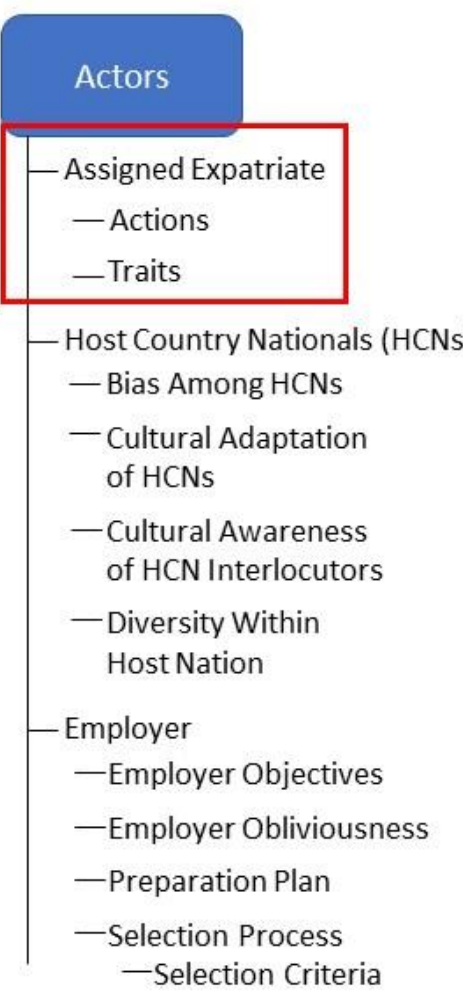

\begin{tabular}{l} 
Contextual \\
Factors \\
\hline - Challenge \\
\hline Expatriate Community \\
- External Events \\
- Host Nation Cultural Factors \\
- Cultural Distance \\
or Distinction \\
- Gender Issues \\
- Language Membrane \\
- Inconvenience or Hardship \\
- Living Conditions \\
- Local Methods \\
- Local Power Structure \\
- Other Expatriate Cultures \\
- Physical Security \\
- Physical Well-being \\
- Separation From Home Culture
\end{tabular}

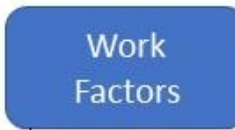

Breadth/Depth of Duties - Broad Duties

—Elevated Responsibilities

-Ground Level Duties

- Conflict with Employer

- Distinctive Characteristics

of the Assignment

-Ambiguity

-Autonomy

- Functions

- Accountability \& Control

-Assessment

- Capacity Building

- Negotiation \& Liaison

- Onboarding

- Organizational Culture

- Organizational Structure
Additional

Questions

(no subordinates)

\section{Expanded View \\ of Inset on \\ Following Page}


Table 9. Expanded Inset from Table 8 - Themes Subordinate to "Assigned Expatriate"

\begin{tabular}{|c|c|}
\hline Actions & Traits \\
\hline Communication to Employer & Assigned Expatriate (AE) Objectives \\
\hline Cultural Adaptation & Awareness of Home Culture \\
\hline Creating Commonalities & Cultural Advantage \\
\hline Cultural Training & Cultural Curiosity \\
\hline Engagement & Cultural Disadvantage \\
\hline Environmental Adaptation & Cultural Humility \\
\hline Interaction with Elites & Expectations \\
\hline Interaction with $\mathrm{HCNs}$ & Family ${ }^{18}$ \\
\hline Language Training & Family Separation \\
\hline Observation \& Inquiry & Flexibility \\
\hline Professional Training & Other Cross-Cultural Experience \\
\hline Repatriation and Reintegration & Perspective Shift \\
\hline Ad Hoc Reintegration & Previous Foreign Language Experience \\
\hline $\begin{array}{l}\text { Poor Utilization of Expatriate } \\
\text { Expertise }\end{array}$ & Respect for Local Nationals \\
\hline Problems With Reintegration & Sincere Desire to Help \\
\hline Reintegration Positives & \\
\hline Volunteering for Overseas Assignment & \\
\hline
\end{tabular}

\section{Selection}

Each interview subject answered the questions, "Please describe how you were selected." The answers to these questions constituted the bulk of the responses in this section. Relevant codes included Selection Process, its sub-theme Selection Criteria, Other Cross-Cultural Experience $^{19}$, and Previous Foreign Language Experience. Every one of the 19 respondents

\footnotetext{
${ }^{18}$ The literature makes clear that family is a huge factor in the expatriate experience. It would normally rate its own factor under the category "Actors." Within this sample, the limited number of expatriates whose families accompanied them made that awkward for this sample.

19 "Can you tell me what experiences you've had as an assigned expatriate?" was the question that prompted many, but not all of the responses coded with this theme.
} 
included text coded with the first three themes. Ten (52.6\%) included text regarding their Previous Foreign Language Experience. As previous foreign language experience was not a specific question, the topic came up organically in responses to other questions. This indicates that previous foreign language experience was relevant, even when it was not the language of the host nation. Using NVivo, I extracted and reviewed all the transcript sections associated with these codes and looked for patterns within them to derive my findings. I used this same method for every subsequent section for the specific themes named.

Table 10. Selection Themes ${ }^{20}$

\begin{tabular}{|c|c|c|c|}
\hline Name & Description & Files & References \\
\hline Selection Process & $\begin{array}{l}\text { The process by which the employer selects personnel } \\
\text { for expatriate assignment }\end{array}$ & 19 & 71 \\
\hline Selection Criteria & $\begin{array}{l}\text { The criteria the employer uses in the expatriate } \\
\text { selection process }\end{array}$ & 19 & 34 \\
\hline $\begin{array}{l}\text { Other Cross-Cultural } \\
\text { Experience }\end{array}$ & $\begin{array}{l}\text { Experience on the part of the expatriate in dealing } \\
\text { with foreign cultures other than the tour covered in the } \\
\text { interview; could be within one's family or in prior } \\
\text { work, schooling, or travel }\end{array}$ & 19 & 62 \\
\hline $\begin{array}{l}\text { Previous Foreign Language } \\
\text { Experience }\end{array}$ & $\begin{array}{l}\text { Previous experience on the part of the expatriate in } \\
\text { learning and using a foreign language }\end{array}$ & 10 & 13 \\
\hline
\end{tabular}

It is important to note that, because selection and preparation are at least partly in the hands of the employer, all 19 subjects described the selection and preparation processes as they experienced them. Even the volunteers went through a selection process to be accepted. The data for this theme is limited by the fact that this study interviewed the selectees, not the selectors, so the data is really the interviewees' secondhand perception of the selection process.

\footnotetext{
${ }^{20}$ For this and subsequent tables, "Files" refers to the number of interview subjects (out of 19) whose interviews included text with this theme. "References" refers to the total number of passages coded with that theme.
} 
In some cases that was informed by the selectors telling the selectees what they were looking for, but in others, the process was quite opaque ${ }^{i}$. Consequently, for any of these assignments, the selectors may have used criteria the subject was unaware of or simply failed to mention.

For ten of the 26 tours (38\%), the subjects described themselves as meeting the minimum professional qualifications (and in some cases, volunteering), and then mentioned no other selection criteria. ${ }^{\text {ii }}$ Of the ten, eight were military tours that can be characterized as low density (few qualified personnel), high demand (high quantity of personnel required), or both.

However, the statistic itself is misleading. For most of the 26 assignments, the selection pool was inherently limited, and those pre-existing hurdles were transparent during data collection. That meant that candidates had already met some criteria even before being considered. One opportunity was available to recent college graduates only. Another favored security specialists already employed by the United Nations. For all fourteen military assignments, the assignment system mandates branch, rank, and career field criteria, among others. Three of the military subjects interviewed were in special operations career fields that require personnel to deploy overseas and work in cross-cultural situations. The selection processes for those career fields include criteria of their own, and some special operations career fields receive specialized training in working cross-culturally.

Formal applications (including essays) and interviews were common for many of the assignments, as they are for domestic positions. While for some assignments it seemed that any minimally qualified "warm body" would do, others were highly selective, including one program that had a $5 \%$ selection rate.

The table below shows the criteria the interview subjects identified as relevant to their selection. 


\section{Table 11. Assignment Selection Criteria ${ }^{21}$}

\begin{tabular}{|c|c|c|}
\hline Assignment Selection Criterion & $\begin{array}{l}\text { Number } \\
\text { (of 26) }\end{array}$ & Notes \\
\hline Professional/technical/academic credentials & 22 & $\begin{array}{l}\text { Includes instances called out in interviews and those understood as part } \\
\text { of military assignments; "academic" applies only to recent graduates }\end{array}$ \\
\hline $\begin{array}{l}\text { Professional/technical/academic credentials } \\
\text { alone or combined only with volunteer status }\end{array}$ & 9 & $\begin{array}{l}\text { Includes seven military }{ }^{22} \text {, one contract linguist supporting the military, } \\
\text { and one graduate student in a program that offered an overseas year }\end{array}$ \\
\hline Previous international experience ${ }^{\mathrm{iii}}$ & 6 & In one case, experience in the specific location was a criterion \\
\hline Prior professional or academic performance & 6 & $\begin{array}{l}\text { In two cases, an influential person observed subject's performance in a } \\
\text { cross-cultural environment for at least three months prior to selection }\end{array}$ \\
\hline Fluency in host nation language & 4 & \\
\hline Soft skills ${ }^{\mathrm{i}}$ & 4 & I.e., self-management, flexibility, open-mindedness, and "people skills" \\
\hline Recommendation from authoritative source ${ }^{\text {iv }}$ & 3 & This is a subset of "Prior professional or academic performance" above \\
\hline Language aptitude / language experience ${ }^{\mathrm{i}}$ & 3 & \\
\hline $\begin{array}{l}\text { Cultural intelligence or interest in cross- } \\
\text { cultural experiences }^{v}\end{array}$ & 2 & $\begin{array}{l}\text { One subject recalled going through a second job interview focused } \\
\text { solely on language and cross-cultural ability }\end{array}$ \\
\hline Psychological evaluation (unknown criteria) & 2 & \\
\hline
\end{tabular}

${ }^{21}$ Criteria mentioned only once included a health evaluation, combat advisor experience, ability to get along with people from military backgrounds, the Foreign Service Exam (a test of general knowledge with portions focused on international affairs, writing skills, and judgment), and, for one development position in Afghanistan, gender.

${ }^{22}$ All seven military positions and the contract linguist position were low density (few qualified personnel), high demand (high quantity of personnel required), or both. Those factors may have contributed to an anemic selection process. However, as detailed below, the military mitigated this effect in some cases by building pools of qualified candidates ahead of the crisis. 


\section{Selection: Findings}

A high number of selections (84.6\%) focused on the same academic, professional, and technical qualifications one might pursue in a domestic position. That is not surprising, as the literature strongly supports the finding. It is also intuitive, as the technical qualifications required to do the job are necessary regardless of geography.

The weight given to international experience also makes sense, as the literature also shows correlation between previous and future success in international assignments. Given that $100 \%$ of this sample volunteered for subsequent overseas assignments after their first, that correlation may actually be causation. A successful overseas assignment may lead people to seek future overseas assignments. As the study continues, other findings will posit the reasons behind that.

One might expect urgency and paucity of candidates to abbreviate and vitiate any personnel selection process - a "desperation effect." The treatment of low density, high demand requirements in this sample demonstrates that well. However, the U.S. military seems to have found a way to mitigate the negative effects of rushed selection and preparation. By selecting and developing special operations and foreign area specialists ${ }^{23}$ specifically for immersive crosscultural work, they demonstrate that planning and developing a pool of candidates for crosscultural work can reduce risk.

Unfortunately, it is difficult for the military to predict its requirements, as political leaders and events outside its control determine where it will work, at what strength, and to what

\footnotetext{
${ }^{23}$ A Foreign Area Officer (FAO) is a commissioned officer of the U.S. military who, having qualified and served in a traditional military career field, develops a second specialty as a regional expert. Qualifying as a FAO typically requires a humanities or social science master's degree focused on the region, extensive foreign language training, and time spent working and travelling in the region (http://www.faoa.org/FAO-What-is-a-FAO). Therefore, while the selection process for this particular position was minimal, they were selecting from a pool of trained candidates.
} 
purpose. Consequently, this pool of selected and trained candidates covers only a small fraction of the U.S. military's requirements for personnel to go abroad and work cross-culturally.

However, the lesson is transferable to the private sector, and the technique may be more effective for multi-national organizations. A company is subject to the vicissitudes of the economy, the industry, and the market. Nevertheless, it still makes its own plans and decisions about where to expand and engage, and it can identify and begin developing candidates for expatriation well ahead of the need to send.

This sample demonstrates to sending organizations both a) the wide variety of methods available to select personnel for overseas assignments and $b$ ) the wide variety of traits and skills an assignment might require. Outside of the commonalities cited above, the biggest pattern was the lack of a pattern. For example, the data indicated that regardless of the category of employer (military, civil government, or private sector), there were organizations and positions that required a rigorous selection process and those that did not. Civil government organizations that specialize in sending people overseas (e.g., the U.S. Department of State and the Peace Corps) nearly became an exception to this inconsistency, as they seemed to have a logical and meticulous selection process. However, the experiences of two employees of the U.S. Agency for International Development (USAID) hired during the civilian surge in Afghanistan $^{24}$ broke that pattern. The process they went through was not negligible, but it was less stringent than that of similar organizations hiring for different locations. This may be another demonstration of the desperation effect cited above. Both USAID subjects had previous successful work experiences overseas, so it is also possible that USAID used those experiences as an expedient proxy for lengthier selection.

\footnotetext{
${ }^{24}$ The civilian surge extended from 2009 to 2014 (Erickson, et al., 2016)
} 
It is worth noting another proxy for lengthy selection that was significant to two overseas tours - one in the private sector, and one for the United Nations. In both cases, individuals with influence over the selection process had observed the candidate working effectively in an overseas environment. No two situations are alike, so such observation is not a guarantee. However, if the opportunity presents itself (or can be fabricated), it may be as certain as any other assessment.

The experience of selection seems to have been qualitatively different between those for whom the selection process was stringent and those for whom it was not, but even more so between those for whom it was transparent and those for whom it was opaque. There is an obvious appeal, from the selectors' perspective, to an opaque process. It is far more difficult to game or second-guess. However, it left some former expatriates in this sample wondering if any thought was given to the process at all. One interview subject speculated that the process of selecting his assignment might have involved a "a monkey throwing things up against a board." This does not imply confidence in the employer. Actions speak louder than words. The selection and preparation processes are opportunities to communicate to the prospective expatriate the quality of the employer's decision-making processes; the value the employer assigns to the expatriate assignment (and consequently the assignee); and the traits and skills the employer believes will enable the employee to succeed.

\section{Selection: Recommendations for Practice}

Identifying candidates who may be suitable for overseas assignments early in their careerwell before the assignment is available or even exists-- can be worth the minimal investment required. Managers can use business trips or short-term assignments as opportunities to observe potential candidates "in action" in cross-cultural environments. Language aptitude tests and 
methods for measuring cultural intelligence are available, as are training courses to enhance cultural intelligence. In a globalized economy with a diverse workforce and an increasing number of teleworkers, many organizations find this kind of training necessary even for employees who never leave the country.

Pre-identifying the specialties most likely to be needed abroad is another approach. When designing scoring rubrics for job applications in the specialties needed, human resources departments can favor successful international experience or foreign language skills. ${ }^{25}$ Since the literature has already shown that clear and accurate expectations increase the chances of an assignment that is both personally rewarding and profitable for the organization, the process of setting those expectations can begin with an employee's initial interview. Advising potential new hires that their future with the company may include opportunities to live abroad gives them time to investigate the option, decide how they feel about it, and even prepare for it independently. It may prevent an ill-informed decision by either the employee or the company.

Human resources specialists can become certified to administer both the tests and the training in-house. For organizations with only a small number of overseas positions - or conversely, a very large number that would distract from core human resource tasks - outsourcing may be more cost-effective. If so, the underutilized global mobility industry is comprised of human resources consultants ready to perform all these services for a fee. Given the great expense involved in sending, sustaining, and repatriating personnel, spending a significantly smaller sum to increase the chances of success seems only prudent.

\footnotetext{
${ }^{25}$ However, when doing so, human resources staffs should be careful not to over limit the pool. A database specialist may be the ideal "hard skill" fit for a position, but a technically capable business analyst with the right people skills may function more effectively.
} 


\section{Preparation}

Relevant themes for this section included (the employer's overall) Preparation Plan, Cultural Training, Language Training, and Professional Training. Each interview subject responded to the question, "How did your organization prepare you (and if applicable, your family) for the assignment?" and those responses constituted the bulk of the passages coded with those themes.

As I describe the training and preparation these expatriates received from their employers, the reader should understand that these represent specific situations and snapshots in time. Whether motivated by embarrassment, a desire for accuracy, or both, several interview subjects reassured their interviewer that the preparation expatriates receive in their organization "is much better now."

For all 26 tours, the expatriate's employer did some kind of preparation, but as with selection, the variance was extreme. For eight of those, interview subjects described nonnegligible full-time language training, ranging from a couple of months to a year. Others had an afternoon of language familiarization or learned key phrases. ${ }^{26}$ As mentioned previously, several were selected specifically for their language skills, rendering training unnecessary. In two cases, the expatriate spoke the host nation language, but the subject did not specifically address this as a factor in selection. Cultural training was often combined with language or professional training, but for 16 of the tours, the subjects received dedicated cultural training. For those tours where interview subjects had received only a few days of cultural training, they were quick to dismiss it as cursory. In other cases, where expatriates had received longer and more rigorous training (sometimes the same expatriate on a different tour), they expressed appreciation and described instances where it made a difference in their assignment. ${ }^{\mathrm{vi}}$

\footnotetext{
${ }^{26}$ These were in cases where interpreters would be available, as discussed below.
} 
Professional training also varied widely and was often contingent and tailored to fit the individual and the job. As one would expect, even those selected for professional qualifications often required training on procedures within an unfamiliar organization or position.

Table 12. Preparation Themes

\begin{tabular}{|l|l|l|l|}
\hline Name & Description & Files & References \\
\hline Preparation Plan & $\begin{array}{l}\text { The set plan the employer has for preparing the } \\
\text { prospective expatriate }\end{array}$ & 19 \\
\hline Cultural Training & $\begin{array}{l}\text { Culture-general or culture-specific training to develop } \\
\text { cultural intelligence/intercultural competence }\end{array}$ & 18 \\
\hline Language Training & $\begin{array}{l}\text { Training to learn a language other than one's mother } \\
\text { tongue }\end{array}$ & 17 \\
\hline Professional Training & $\begin{array}{l}\text { Training to enhance task or mission effectiveness that } \\
\text { is relevant regardless of culture or language }\end{array}$ & 17 \\
\hline
\end{tabular}

\section{Preparation: Findings}

Within the sample, one private sector assignment in the Balkans represents the low end of both formality and substance. The expatriate was working for a small logistics firm. After working for the company for three months in a peaceful European country, his employer sent him to Serbia during the Kosovo War.

In this case, selection trumped preparation. This is one of the two cases explained above wherein the selector made his choice based on his observation of the expatriate's work in a crosscultural environment. The selector, in this case his supervisor for both positions, told him that two previous employees had already left the position. He was sending the interview subject specifically because the subject needed little preparation. The subject had a military background that prepared him to deal with both the living conditions and the security situation. He had proven cross-cultural skills and he understood the task requirements because he had been doing 
similar logistics work under the employer's supervision for months. However, even in that scenario, the employer briefed the expatriate on his duties and the conditions he would be working under.

Another slightly more formal example, but still lacking in substance, was the preparation for a service member's tour in Germany, working on an air base alongside host nationals and negotiating with the German government. In this case, the preparation plan consisted of assigning a sponsor at the receiving base to answer any questions and putting the service member through a few days of briefings upon arrival in Germany. The briefings covered practical differences between the home and host nation environment, such as differences in traffic laws. For the expatriate this was sub-optimal, but not wholly inadequate. The military was probably able to "get by" with such rudimentary preparation due to several circumstances specific to the assignment:

1) Relatively low cultural distance between home and host nation

2) Lack of other environmental stressors (highly developed, peaceful environment)

3) Strong support structure consisting of both home country and host country nationals

That said, a United Nations security officer interviewed received similarly meager preparation when he went to Cambodia. In that case, only the last of those mitigating circumstances were true. There, his employers provided support with important practical matters, such as securing suitable lodging. While he regretted the lack of preparation (since corrected, he assured me), he was still grateful years later for that practical support.

The military also controls the territory at the other end of the preparation spectrum. For the one assignment in Israel within the sample, the expatriate was a Middle East foreign area officer. As a foreign area officer, he had received a year's training in Hebrew, with material and 
instruction he could share with his family. He also spent another year traveling and working in the Middle East with his family under the mentorship of American military expatriates. The specific intent of that year was to enable him and his family to live and work effectively as expatriates. Had this officer not already had a master's degree in a topic related to the region, the military would have sponsored him in such a degree program.

In this case, however, while his language and cultural training were superb, his professional training received short shrift. He was sent to Israel to represent a service major command - the equivalent of a major division in a multinational conglomerate. He had been exposed to that major command and received professional services from them, but he had never worked for them. To fill that gap, he received one week of training on the command's activities and methods. The expatriate deemed this inadequate, but he made it work. ${ }^{\text {vii }}$

The Peace Corps' preparation plan is another "high end" exemplar. After spending a weekend in the U.S. learning from recent repatriates from the region, Peace Corps volunteers spend two months in country in preparation. Their days are spent learning language, history, culture, and practical survival knowledge, and their nights are spent living with a host family who act as their host nation mentors.

The U.S. government is not the only employer willing to pay a prospective expatriate to spend all his working hours preparing for months on end. Another interview subject, originally a citizen of the People's Republic of China, entered a cross-cultural partnership program wherein she spent a year learning Japanese so that she could work in a major Japanese corporation as an information technology professional. But the assignments in this program were planned far in advance, so there was no urgency, and it was a private-public partnership. Both the PRC government and the corporation had the resources to spend. viii $^{\text {ii }}$ 
Within this sample, preparation in the private sector was less time-consuming and sometimes less rigorous than the best examples of government-sponsored training. One executive with two long "flexpatriate" tours in Mexico described a week of preparation and a month of preparation, respectively. On his first assignment, this expatriate was unversed in Mexican culture, but spoke Spanish fluently. In both cases, preparation focused on relationships and organizational objectives and processes.

${ }^{\mathrm{ix}}$ Most of the preparation plans described by interview subjects fell in-between these extremes. They were the result of compromises between time, money, and requirements, especially for organizations sending people to multiple locations. In this middle ground, employers tried to group as many together as possible while still maintaining the applicability of the training. As early as 1981, Rosalie Tung argued for contingent training tailored to fit the person, the job, and the location, not a "cookie cutter" approach. Unfortunately, specificity, and consequently training value, are very often sacrificed for efficiency. In one instance, this meant a UN peacekeeper headed to Mali trained alongside others headed to Israel, Tunisia, and South Sudan. In such situations, the training that is most effective is the training that is inherently applicable to a broad audience. The prospective peacekeeper's professional training as a peacekeeper was valuable, but much of his cultural training consisted of culture-general information delivered through PowerPoint slides. His interaction with the team currently in Mali consisted of a thirty-minute video teleconference. ${ }^{\mathrm{x}}$

If physical security or well-being are a serious concern in the host nation, the biggest winner in these trade-offs is typically training that keeps the expatriate alive. Military personnel going to combat assignments described year-long training cycles wherein time spent developing tactical effectiveness outweighed time spent on culture, geography, history, and relational skills 
by a ratio of three or four to one. These were for assignments wherein the primary task was not combat, but working with host country nationals. ${ }^{x i}$ Even non-military personnel (development workers, contract translators, etc.) going to a conflict zone spent far more time training to survive than they did training to accomplish the mission. ${ }^{\text {xii }}$

Similarly, those going to the developing world who received extensive training in other areas, such as the Peace Corps volunteers, also received training to counter environmental hazards, including how to avoid infection and treat disease and injury. This environmental training, much like the combat training for soldiers, was difficult to disambiguate from professional training, especially as some of those who received had health-related specialties.

Not a single interview subject argued that their training to stay healthy and whole should have been curtailed at all. They only argued that additional training should have been provided on culture, history, demographics, language, and non-combat tasks. Multiple interview subjects who had served in conflict zones described training that combined all these objectives. In this style of training, individual skills in tactics, mission tasks, relational skills, language, etc. were developed separately, but then used all at once in scenario-based training with trainers playing the role of host country nationals. ${ }^{\text {xii }}$

Without prompting, one advocated for combination training as the most efficient use of preparation time. She and others also emphasized the value of overlap with those being replaced and training alongside those with whom one will serve, implying that the relationships developed were as important to mission effectiveness as the curriculum itself. ${ }^{x i v}$

Just as survival is privileged over other topics in conflict zones, the interviews show that in any environment wherein interpreters are available, language training receives the lowest priority. This is true despite literature (and the interview subjects themselves) emphasizing the 
value of language not merely for transferring information, but for building relationships and understanding the perspective of host country nationals (Ryan, 2017). The lack of language training is most likely because language instruction is time-consuming and expensive. However, as with effective cultural training (with which language training can be combined), those who receive it emphasize its value.

Concerned that the preparation from their employers would be inadequate, expatriates often took steps to prepare themselves through self-procured language study or reading about the culture and the society. ${ }^{\mathrm{xv}}$

Preparation: Recommendations for Practice

Again, with a wide enough pool of candidates, selection can trump preparation. When an organization needs someone in Country X right away, the best way to avoid an expensive and time-consuming preparation-without sacrificing effectiveness-is to select someone who is already $90 \%$ prepared. There are several ways to do that, from "head-hunting" for specific background and skills (and being willing to pay for them) to developing them or recruiting for them in-house over time.

Still on the topic of selection as a key to preparation, the literature already explained what to look for. Cultural intelligence (also known as intercultural competence, cultural agility, etc.) is really a combination of knowledge, traits, and abilities that enable someone to learn to operate in a new culture. Given the ability, one needs motivation. The literature also covered that in its discussion of learning orientation (Porter \& Tansky, 1999) or learning goal orientation (Feitosa et al., 2014). Preparation is critical, but often resourced below the point at which returns begin to accelerate - far below the point at which they begin to diminish. That said, an expatriate with 
cultural intelligence and a learning goal orientation will work on his own to fill in the gaps for whatever preparation cannot anticipate or provide. ${ }^{\mathrm{xvi}}$

To the degree possible, the expatriate should train in the target environment, alongside the people with whom he or she will work. Those preparing the plan of instruction should combine more than one type of training (language, culture, professional, etc.) whenever they can - not only for efficiency, but for synergistic effect. Finally, employers should plan ahead, spend the money, and take the time required. As stated previously, actions speak louder than words. A deliberate investment in preparation not only minimizes risk and maximizes return, it communicates the importance of the employee, the overseas assignment, and the foreign operation as a whole - all messages a multinational organization would logically want to send.

\section{Life and Work Abroad}

This section covers the expatriate assignment itself. As the interview subjects relate their experiences, there is tremendous overlap between the theme categories of Actors, Contextual Factors, and Work Factors. The series of tables following immediately below will show the themes within those categories (excepting those associated with repatriation) with their definitions and their prevalence within the interview text.

Table 13. Actors/Assigned Expatriate/Traits Themes

\begin{tabular}{|c|c|c|c|}
\hline Name & Description & Files & References \\
\hline Traits & $\begin{array}{l}\text { Qualities, thoughts, feelings, behaviors, attitudes, or } \\
\text { circumstances specific to the AE }\end{array}$ & 19 & 663 \\
\hline AE Objectives & $\begin{array}{l}\text { Those objectives the AE is personally motivated to } \\
\text { achieve through the assignment, which may be either } \\
\text { duplicative or additive to the employer's objectives }\end{array}$ & 17 & 66 \\
\hline
\end{tabular}


Table 13 (Continued)

\begin{tabular}{|c|c|c|c|}
\hline Name & Description & Files & References \\
\hline $\begin{array}{l}\text { Awareness of Home } \\
\text { Culture }\end{array}$ & $\begin{array}{l}\text { The ability to recognize within one's own thoughts, } \\
\text { feelings, behaviors, attitudes, and methods the effect } \\
\text { of one's own culture and distinguish those effects } \\
\text { from both personal idiosyncrasies and the human } \\
\text { condition }\end{array}$ & 15 & 46 \\
\hline Cultural Advantage & $\begin{array}{l}\text { Qualities or personal circumstances of the expatriate } \\
\text { which aid adjustment, HCN acceptance, or } \\
\text { effectiveness within the host nation culture }\end{array}$ & 9 & 19 \\
\hline Cultural Curiosity & Intrinsic interest in the host nation culture & 15 & 41 \\
\hline Cultural Disadvantage & $\begin{array}{l}\text { Qualities or personal circumstances of the expatriate } \\
\text { which hinder adjustment, HCN acceptance, or } \\
\text { effectiveness within the host nation culture }\end{array}$ & 9 & 21 \\
\hline Cultural Humility & $\begin{array}{l}\text { Awareness that one's skills and methods are } \\
\text { optimized for the home culture, creating an } \\
\text { appreciation of and willingness to learn from host } \\
\text { national contributions (Caligiuri et al., 2016) }\end{array}$ & 16 & 56 \\
\hline Expectations & $\begin{array}{l}\text { Expatriate's expectations regarding the assignment } \\
\text { and repatriation }\end{array}$ & 19 & 84 \\
\hline Family & $\begin{array}{l}\text { Issues involving the expatriate's family, especially } \\
\text { when they accompany the expatriate }\end{array}$ & 11 & 34 \\
\hline Family Separation & $\begin{array}{l}\text { Issues regarding expatriate's separation from family } \\
\text { while on the assignment abroad }\end{array}$ & 6 & 9 \\
\hline Flexibility & $\begin{array}{l}\text { Flexibility on the part of the expatriate when } \\
\text { confronted with new thoughts, feelings, attitudes, } \\
\text { behaviors, and methods, or alternately, when } \\
\text { confronted with the need for such things }\end{array}$ & 15 & 48 \\
\hline $\begin{array}{l}\text { Other Cross-Cultural } \\
\text { Experience }\end{array}$ & $\begin{array}{l}\text { Experience on the part of the expatriate in dealing } \\
\text { with foreign cultures other than the tour covered in } \\
\text { the interview; could be within one's family or in prior } \\
\text { work, schooling, or travel }\end{array}$ & 19 & 62 \\
\hline Perspective Shift & $\begin{array}{l}\text { The ability to see an issue or situation from someone } \\
\text { else's perspective and understand how different } \\
\text { circumstances change one's assessment or reaction }\end{array}$ & 17 & 87 \\
\hline
\end{tabular}


Table 13 (Continued)

\begin{tabular}{|c|c|c|c|}
\hline Name & Description & Files & References \\
\hline $\begin{array}{l}\text { Previous Foreign } \\
\text { Language Experience }\end{array}$ & $\begin{array}{l}\text { Previous experience on the part of the expatriate in } \\
\text { learning and using a foreign language }\end{array}$ & 10 & 13 \\
\hline Respect for $\mathrm{HCNs}$ & $\begin{array}{l}\text { Expatriate's demonstrations of respect for host } \\
\text { country nationals in actions or attitude }\end{array}$ & 17 & 61 \\
\hline Sincere Desire to Help & $\begin{array}{l}\text { Expatriate's desire to help HCNs and the host } \\
\text { organization (e.g., foreign office) }\end{array}$ & 13 & 25 \\
\hline
\end{tabular}

Table 14. Actors/Assigned Expatriate/Actions Themes

\begin{tabular}{|c|c|c|c|}
\hline Name & Description & Files & References \\
\hline Actions & $\begin{array}{l}\text { Actions taken by the } \mathrm{AE} \text { in support of or as a result of } \\
\text { the assignment }\end{array}$ & 19 & 873 \\
\hline $\begin{array}{l}\text { Communication to } \\
\text { Employer }\end{array}$ & $\begin{array}{l}\text { Knowledge transfer from the foreign office to the } \\
\text { home office (or at least up the supervisory chain) } \\
\text { during the assignment }\end{array}$ & 9 & 25 \\
\hline Creating Commonalities & $\begin{array}{l}\text { Finding, generating or highlighting points of } \\
\text { similarity with HCNs to build rapport }\end{array}$ & 8 & 13 \\
\hline Cultural Adaptation & $\begin{array}{l}\text { Adjusting thoughts, feelings, or behaviors to better fit } \\
\text { the culture }\end{array}$ & 19 & 84 \\
\hline Engagement & Interaction with the host nation culture & 19 & 148 \\
\hline $\begin{array}{l}\text { Environmental } \\
\text { Adaptation }\end{array}$ & $\begin{array}{l}\text { Adjusting thoughts, feelings, or behaviors to better } \\
\text { address non-cultural aspects of the environment, such } \\
\text { as the climate, security situation, or hazards to health }\end{array}$ & 14 & 59 \\
\hline Interaction with Elites & Dealings with HCNs and other expats of high status & 14 & 36 \\
\hline Interaction with $\mathrm{HCNs}$ & Dealings with HCNs in general & 19 & 152 \\
\hline Observation \& Inquiry & $\begin{array}{l}\text { Investigating the host environment to enable } \\
\text { adaptation and mission effectiveness, especially the } \\
\text { thoughts, feelings, behaviors, relationships, } \\
\text { organization, and methods of the HCNs }\end{array}$ & 15 & 66 \\
\hline $\begin{array}{l}\text { Volunteering for } \\
\text { Overseas Assignment }\end{array}$ & $\begin{array}{l}\text { Choosing to go abroad for reasons of personal } \\
\text { motivation, and not because of external pressure }\end{array}$ & 16 & 36 \\
\hline
\end{tabular}


Table 15: External Actors (Actors/Host Country Nationals \& Actors/Employers) Themes

\begin{tabular}{|c|c|c|c|}
\hline Name & Description & Files & References \\
\hline Employers & $\begin{array}{l}\text { The geographically separated supervisor or } \\
\text { employing organization who are not HCNs }\end{array}$ & 19 & 171 \\
\hline Employer Objectives & $\begin{array}{l}\text { The purposes the employing organization has for } \\
\text { sending the expatriate and/or the objectives the } \\
\text { employer wants the expatriate to achieve in a } \\
\text { particular situation }\end{array}$ & 13 & 34 \\
\hline Employer Obliviousness & $\begin{array}{l}\text { Demonstrations or effects of the employer's } \\
\text { ignorance of the conditions or circumstances of the } \\
\text { expatriate's life and work }\end{array}$ & 13 & 24 \\
\hline Preparation Plan & $\begin{array}{l}\text { The set plan the employer has for preparing the } \\
\text { prospective expatriate }\end{array}$ & 19 & 42 \\
\hline Selection Process & $\begin{array}{l}\text { The process by which the employer selects personnel } \\
\text { for expatriate assignment }\end{array}$ & 19 & 71 \\
\hline Selection Criteria & $\begin{array}{l}\text { The criteria the employer uses in the expatriate } \\
\text { selection process }\end{array}$ & 19 & 34 \\
\hline Host Country Nationals & $\begin{array}{l}\text { Citizens of the country in which the expatriate lives } \\
\text { and works while on assignment }\end{array}$ & 17 & 84 \\
\hline Bias Among HCNs & $\begin{array}{l}\text { Categorization, stereotyping, preference, or prejudice } \\
\text { between sub-groups of } \mathrm{HCNs}\end{array}$ & 12 & 26 \\
\hline $\begin{array}{l}\text { Cultural Adaptation of } \\
\text { HCNs }\end{array}$ & $\begin{array}{l}\text { Instances of } \mathrm{HCN} \text { adaptation to the thoughts, } \\
\text { feelings, attitudes, behaviors, and methods of the } \\
\text { expatriate }\end{array}$ & 11 & 19 \\
\hline $\begin{array}{l}\text { Cultural Awareness of } \\
\text { HCNs }\end{array}$ & $\begin{array}{l}\text { Demonstrations of } \mathrm{HCN} \text { knowledge of the } \\
\text { expatriate's culture }\end{array}$ & 9 & 11 \\
\hline $\begin{array}{l}\text { Diversity Within Host } \\
\text { Nation Culture }\end{array}$ & $\begin{array}{l}\text { The variegation of people, beliefs, and ways of life } \\
\text { within }\end{array}$ & 11 & 28 \\
\hline
\end{tabular}




\section{Table 16: Contextual Factors Themes}

\begin{tabular}{|c|c|c|c|}
\hline Name & Description & Files & References \\
\hline Challenge & $\begin{array}{l}\text { The increased difficulty and complexity of life and } \\
\text { work as an expatriate and the stimulation that arises } \\
\text { from that difficulty and complexity }\end{array}$ & 14 & 65 \\
\hline Expatriate Community & $\begin{array}{l}\text { The presence of other expatriates in the subject's } \\
\text { environment and his or her interaction with them }\end{array}$ & 10 & 32 \\
\hline External Events & $\begin{array}{l}\text { Events outside the host nation affecting the expatriate } \\
\text { and his interaction with HCNs }\end{array}$ & 9 & 15 \\
\hline Host Nation Cultural Factors & $\begin{array}{l}\text { All the ways the host nation culture affects life and } \\
\text { work for the expatriate }\end{array}$ & 17 & 142 \\
\hline $\begin{array}{l}\text { Cultural Distance or } \\
\text { Distinction }\end{array}$ & $\begin{array}{l}\text { Differences between the host nation culture and the } \\
\text { expatriate's home culture }\end{array}$ & 15 & 94 \\
\hline Gender Issues & $\begin{array}{l}\text { Cultural or environmental differences regarding male } \\
\text { and female roles and relationships that become } \\
\text { relevant during the assignment }\end{array}$ & 9 & 22 \\
\hline Language Membrane & $\begin{array}{l}\text { Complexity, difficulty, or misunderstanding due to } \\
\text { people having different first languages }\end{array}$ & 12 & 26 \\
\hline Inconvenience or Hardship & Difficulty or adverse condition in the host nation & 13 & 45 \\
\hline Living Conditions & $\begin{array}{l}\text { The expatriate's accommodations and living } \\
\text { environment }\end{array}$ & 19 & 73 \\
\hline Local Methods & $\begin{array}{l}\text { Methods HCNs employ, which differ from those to } \\
\text { which the expatriate is accustomed }\end{array}$ & 15 & 66 \\
\hline Local Power Structure & The power structure the HCNs operate within & 13 & 36 \\
\hline Other Expatriate Cultures & $\begin{array}{l}\text { Expatriates from another (third) culture and their } \\
\text { effects in the environment }\end{array}$ & 14 & 43 \\
\hline Physical Security & The potential for violence in the assignment area & 18 & 73 \\
\hline Physical Well-being & Health and factors detrimental to health & 13 & 43 \\
\hline Separation From Home Culture & $\begin{array}{l}\text { Expatriate's feelings of separation from his or her } \\
\text { home culture }\end{array}$ & 11 & 17 \\
\hline
\end{tabular}


Table 17: Work Factors Themes

\begin{tabular}{|c|c|c|c|}
\hline Name & Description & Files & References \\
\hline Breadth and Depth of Duties & The range (vertically and horizontally) of expat duties & 19 & 156 \\
\hline Broad Duties & $\begin{array}{l}\text { Expatriates having a wider and more varied range of } \\
\text { duties than in their typical domestic position }\end{array}$ & 17 & 54 \\
\hline Elevated Responsibilities & $\begin{array}{l}\text { Duties expatriates accomplish while abroad, for which } \\
\text { more senior people would be responsible at home }\end{array}$ & 13 & 39 \\
\hline Ground Level Duties & $\begin{array}{l}\text { Routine, simple, concrete tasks; may involve direct } \\
\text { contact with the customer, product, or service } \\
\text { provided; may be menial jobs required for larger tasks }\end{array}$ & 16 & 63 \\
\hline Conflict with Employer & $\begin{array}{l}\text { Disagreement with geographically separated elements } \\
\text { of the organization, especially higher-level elements }\end{array}$ & 9 & 19 \\
\hline $\begin{array}{l}\text { Distinctive Characteristics of } \\
\text { the Assignment }\end{array}$ & $\begin{array}{l}\text { Aspects of the expatriate's work abroad (not included } \\
\text { under other factors) distinguishing that work from }\end{array}$ & 15 & 63 \\
\hline Ambiguity & $\begin{array}{l}\text { A low degree of role clarity often associated with } \\
\text { expatriate work }\end{array}$ & 14 & 28 \\
\hline Autonomy & $\begin{array}{l}\text { A high degree of role discretion often associated with } \\
\text { expatriate work }\end{array}$ & 14 & 35 \\
\hline Functions & Functions associated with assigned expatriate position & 19 & 108 \\
\hline $\begin{array}{l}\text { Accountability and } \\
\text { Control }\end{array}$ & $\begin{array}{l}\text { Exerting control over the host nation partner or } \\
\text { element }\end{array}$ & 7 & 20 \\
\hline Assessment & Evaluation of the host nation partner or element & 10 & 26 \\
\hline Capacity Building & $\begin{array}{l}\text { Increasing the quantity, quality, or variety of } \\
\text { capabilities of the host nation partner or element }\end{array}$ & 16 & 48 \\
\hline Negotiation \& Liaison & $\begin{array}{l}\text { Representing the home office to host nation } \\
\text { interlocutors within the organization or the } \\
\text { organization in general to those outside it }\end{array}$ & 4 & 14 \\
\hline Onboarding & Transitioning into the overseas position & 11 & 21 \\
\hline Organizational Culture & Culture of the employing organization & 13 & 26 \\
\hline Organizational Structure & Structure of the employing organization & 11 & 20 \\
\hline
\end{tabular}


Through analysis of the passages of interview text associated with each them, cross-cutting meta-themes emerged, laced throughout the findings: Relationships, Learning, and Engagement. The findings related to Life and Work Abroad can be categorized as relating to either Context \& Adaptation or the Nature of the Work.

Before addressing the overseas experiences themselves, it is important to note that some experiences have been excluded as outside the scope of this study. As noted above, several of the interview subjects served as expatriates in conflict zones. When asked about their most powerful experiences, some of them reported experiences of great loss, tragedy, and futility. These experiences and the insights gleaned from them were formative and profound, but they have more to do with the phenomenology of war than that of working as an expatriate. To include them in this study would be a disservice to both topics.

\section{Context \& Adaptation}

Interviewer: What adjustments did you have to make regarding life and work in your host nation?

Interview Subject (Gambia): Everything. We were given a little burner phone, Nokia. There was no electricity, no running water. That part was the easy part to adjust to.

\section{A New Standard of Living}

All of the interview subjects described adjustments they had to make - some quite extensive. ${ }^{\text {xvii }}$ These findings describe the lived experiences of expatriates engaging their new environment and adapting to it. At first, the most striking differences demanding the expatriate's adaptation may be circumstantial and environmental. For example, almost every expatriate interviewed had to adjust to a new standard of living. Like their experiences with selection and preparation, expatriates' living conditions varied widely, from a mud hut to a five-star resort. In some cases, expatriates moved to a higher standard of living, driven by a low cost of living in the host nation, more advanced development in the host nation, or a need for a highly secure living 
space. Others lived in more primitive conditions to more effectively connect with host country nationals or because the exigencies of war demanded it. This was another area wherein the interviews supported the literature, in this case the literature's emphasis on accurate expectations. Those in the most primitive living conditions were often well-prepared to expect them and seemed to accept them without complaint. ${ }^{\text {xviii }}$

Priorities and requirements regarding living standards also differed. One expatriate discovered she could get by in the most primitive environment if she had a space that was her very own. Another proudly described his living conditions as excellent, then went on to describe how unassailable his camp was from physical attack. The conditions were in fact quite spartan, but to him, comfort was irrelevant in comparison to security.

Without prompting, several of those who had adjusted to a lower living standard and/or a less secure environment talked about the need for a refuge - a place where one could relax, commune with expatriates of similar background —or at least less culturally distant than the HCNs—and enjoy the amenities of the developed world. ${ }^{\text {xix }}$ In contrast, two interview subjects deliberately eschewed contact with other expatriates to increase their engagement with the host nation culture. Perhaps not coincidentally, they were the two with the most intense preparation in culture and language, and they had transitioned to a host country lifestyle that was at least as comfortable as that of home. ${ }^{\mathrm{xx}}$

Finally, it's important to note that living conditions at either end of the spectrum can affect an expatriate's work, his or her purpose for being there. In the Peace Corps, the volunteers live with and in the same manner as the host country nationals in the developing world. By doing so, they maximize their integration with the community they serve. At the other extreme is an expatriate whose office is in Mexico City, but who also travels to other locations in Latin America, the 
Caribbean, and Europe. Working in the hospitality and vacation industry, he stays in resort hotels, has an expense account for food and drink, and has full medical coverage. When in Mexico City, he often has a driver. ${ }^{x x i}$

There is a significant expense associated with this level of care, but the return on investment may be worth it. In the interview, this expatriate spoke in an appreciative tone, repeatedly using phrases like, "I didn't have to worry," and "I cannot complain." He described very challenging tasks, such as learning Costa Rica's tax structure in only days so his employer could rapidly enter the market and taking care of company staff and property in the Caribbean after devastating hurricanes. But he seemed to have no concerns outside of work, as if his employer had taken care of every major practical life issue. In doing so, they certainly reduced the expatriate's stress level. They may have guaranteed his mission focus and his loyalty, resulting in a significant net profit.

This serves as a partial answer to one of the questions I asked in Chapter One, "What does the expatriate need from the home office?" The expatriate needs practical support in securing practical necessities in a radical new environment - a place to live, a place to buy food, a place to get medical care, etc. Even the expatriate to Cambodia's disappointment over the lack of cultural preparation was mitigated by his gratitude for the United Nations' help in finding suitable housing.

Finally, the living conditions in that new environment can vary widely, but they should not do so at random. The living conditions can have a significant impact on mission effectiveness and the personal well-being of the expatriate and his or her family, and they should be chosen with those concerns in mind. 


\section{New Vistas}

Previous academic literature notes that some people go on expatriate assignment for the adventure, but it does little to describe what that adventure entails. When asked about powerful experiences, subjects often described singular or exquisite moments they would never have experienced had they not served as expatriates - using the public baths in Morocco, visiting a live volcano in Japan, or seeing the ancient Mesoamerican city of Teotihuacan. Some were more mundane, but just as striking. ${ }^{x x i i}$

Exemplar (Mauritania): In the heart of the country, you're going forever in what feels like Mars, and then all of a sudden there's life in a village. And it's just absolutely amazing, seeing the edge of the Sahara Desert and realizing there are no lights there whatsoever and what the sky looks like. And then thinking about the threat that's in the area. And of course, you're merging eight old caravan routes, and you'd see these guys come out of nowhere. How they're alive is beyond me, but they have a whole herd of cattle and all this stuff with them. Impossible to replicate that experience, I think.

In these expeditions, the expatriates interviewed were generally accompanied by local guides, usually someone with whom they worked. The shared experiences become the foundation for friendships, and those friendships become a masters class on the host nation culture.

Exemplar (Spain): Same thing happened in Madrid, nothing to do with work. He became my friend, the controller out there at the office who reported to me at the time, we decided to go around the city. And he came from a town called Zaragoza, a region called Zaragosa in Spain. And he told me that his family was very big about ham. And I was like, "What's big about ham? Just ham." He said, "No, no, no. This is special ham." And then he took me to different places for me to taste... very expensive ham but very, very delicious ham. And then we spent a whole weekend, just going different little bars in different places. Just taking tapas, drinking what they call cañas and eating ham, and just spending time with people there.

I mean, to me, those types of experiences, everywhere I went, Costa Rica the same thing, to me, those were the most powerful things because they allow me to, they open the door to what the culture is really, how the people are. I think it enriched myself as a professional, as a person, more than anything and helped me understand and appreciate that other culture. 


\section{$\underline{\text { A New Way of Life }}$}

I asked the interview subjects what adjustments they had to make regarding life and work in the host nation. Every one of them had examples; the number and degree depended upon the cultural distance and the degree to which their circumstances differed. But even in cultures and environments that were relatively similar, the differences mattered. One subject related her adventures negotiating Italy, one of the oldest Western societies. For six weeks, she lost weight, because she could not consistently match her schedule to when the stores and restaurants were open. She went to clothing stores to replace her athlete's wardrobe with one that properly beautified Italy (the local standard) and found herself under the command of sales staffs who were determined to correct her errant ways. She changed how she approached breakfast and how she worked out and even how she rehabilitated an injury. It all came with a cost, but it was necessary in order to adapt to Italian society and build relationships. ${ }^{\text {xxiii }}$

Some changes directly related to the way people work together. The foreign area officer in Israel described the courteous manner of speech commonly used to disagree with superiors in the American military. In Israel, he had to be more direct, even with generals, or be seen as obfuscating. ${ }^{\text {xiv }}$ Other necessary adjustments were responses to conditions, such as oppressive heat, contaminated water, landmines hidden in city parks, and a breakdown of legitimate institutions. These had nothing to do with culture, but their effect was similarly profound. ${ }^{\mathrm{xxv}}$

\section{Bias, Bigotry, Sex and Corruption in the Host Culture}

Some of the most glaring reminders that the host nation culture was different from the home culture manifested in the way host country nationals related to one another. Differences in class or ethnicity for which the expatriate had no context were significant within the host culture and had to be accounted for. One subject described learning that his interpreter's ethnicity or place 
of origin might affect how an interlocutor perceived them or their message. Another went further, describing an instance wherein a host national was motivated to skew the organization's dealings with his compatriots based on those differences. For the interview subjects, these nuances were often not covered in the preparation phase. As expatriates, they had to learn the class system internal to that society and how to navigate it to accomplish their objectives, while striving to stay true to their principles. ${ }^{\mathrm{xxvi}}$

Similarly, relations between men and women and their respective places in society often vary widely between cultures. One subject who worked in a clinic in Africa described watching women hide documentation of their contraceptive injections so their husbands wouldn't know they were on birth control. Another joked with the male host country nationals he worked with that he thought they were angels that had fallen from the sky, because he never saw any wives or mothers.

One Peace Corps volunteer saw these differences, among others, as differences in "what it meant to be human." They were profound differences in areas central to human existence (relations with other people, the opposite sex, even food). They revealed that much of what he had thought was essential was merely a cultural construct - that there were, in fact, other ways to live. ${ }^{\text {xxvii }}$

Obviously, people are sensitive to these issues of morality and humanity, and they can cause offense. One subject, a member of the foreign service, proposed that regardless of one's cultural intelligence or level of preparation, anyone who was truly immersed in another culture would, at some point, be taken aback by an occurrence that in that society was seen as normal. ${ }^{27}$ "It's just

\footnotetext{
${ }^{27}$ With the exception of Barker \& Cobb's 1999 discussion of the need for ethical training to deal with conflicting cultural values, this is not a point this researcher found in the literature. However, it was echoed in the experiences of other interview subjects.
} 
so far out of your realm of understanding, even if you've read, even if you've thought about it, even if you've been talking to people from that country in the States, you're in a situation where, 'Wow, that really just happened, and I don't know how to handle that."' He described watching a play, put on by a women's program he had helped to fund. It described the situation of abused wives in Tajikistan. Watching the play, he realized that these women, with no education, no resources, no defenders, and no status in society except as defined by their relationship to males, had no options that did not come with great cost. He was a Westerner with more enlightened values, government funding, and a diplomatic platform, but there was little he could do to change those options, and that realization disturbed him. ${ }^{\text {xxviii }}$

Violence against women came up in another interview, and rapacious corruption and genocide came up in a few. Of course, many would argue that, unlike mating rituals, these transgressions are not characteristic of any particular culture, but are in fact intrinsically human. Nevertheless, some cultures and some societal circumstances are more enabling than others.

A subject describing his experience in Mauritania expressed concern over how that moment of offense and his reaction to it could affect the work.

Even recognizing how my face reacts to things...like "The whole meeting is going to go south now, because I recoiled at something you've said that has probably offended me, but may not actually be offensive."...In those moments...I lose sight of the broader thing that I'm trying to do there, the broader conversation.... Those are just lessons that have to be continuously learned or retold, because I think it's easy to have that, "I'm an American official" coming back in your head. ${ }^{\text {xix }}$

Only one subject mentioned instruction he received during the preparation phase that was applicable to these situations.

The CO [commanding officer] of USMOG [U.S. Military Observer Group] ...a brilliant guy [who] spent most of his time in Africa...very positive person....He always said, "The one thing...you've got to remember in these cultural considerations is...the serenity prayer. Dear God, please help me to accept the things I cannot change." And that's the one thing...he kept homing in on. 


\section{$\underline{\text { Stereotypes and Assumptions }}$}

In another experiential finding new to the literature, in addition to coping with unpleasant truths, expatriates have to root out persistent fiction. Several subjects made the point that expatriate assignments will expose, refine and even disprove one's beliefs about a people or a nation. In some cases, that may include beliefs formally taught in the preparation phase. For example, an interview subject who worked in Sarajevo in 1997 had previously learned that the peoples of the former Yugoslavia had "ancient ethnic hatreds" toward one another. However, she found that the overwhelming majority of the people were not ethnic nationalists at all, but were driven to fight and to support nationalists in reaction to violence. This was part of a cycle of violence initiated by a minority of true ethnic nationalists, or at least people who exploited ethnic nationalist ideology to gain power and territory. ${ }^{\mathrm{xxx}}$

\section{Otherness}

A few interview subjects described their awareness that no matter how well they adjusted, they would never be fully part of the host nation culture. ${ }^{\mathrm{xxi}}$

Exemplar (Italy): You go to the department store. . . and you go to the area where they keep the sheets ... and the floor is glass, and you look down and you're walking on top of Etruscan ruins. This society has been there since there was society and they don't just let people in, which was, I think, a very interesting a thing to learn.

Exemplar (Korea): [Speaking of cultural adaptation techniques] Do I understand all these things? Well, I understand them from an outsider's perspective, but I certainly don't understand them as if I've lived them. You just acknowledge that, right? You're never going to be from there. . . I I always acknowledge that no matter how much study and how much I try to pay attention to those things that it's not going to be really the same as having been immersed in that culture from birth and knowing it firsthand.

Exemplar (Afghanistan): I think I really got good at dealing with Afghans and Afghan culture there. This was my fourth deployment, so I better have gotten better, but I think by that point I really understood what was going on, and I really dug deep into the culture and the history. So, I made adjustments to understand what was going on, and I could read situations better. I could read when they were just lying to me, which is fine, and when they were trying to play me, which is fine. I would do the same thing. No judgment. And how to, basically, maneuver through that area blindfolded. 
That's what it is. That's how I describe it as. You have to maneuver through a. . . cultural minefield, blindfolded. And you have to learn how to sense through that. That's how I would describe it. Because you can't-you're never going to see it completely because I'm a white guy from Texas and my Pashto probably hurts their ears. So, you have to learn how to go through something like that, and it's not for everybody. And then you really have to learn how to do it.

As previously mentioned, interview subjects related many instances of host country nationals going out of their way to share their culture, often through sharing food or visiting distinctive sights. These experiences of welcome and acceptance were among the most cherished of the expatriates' assignments, as they made the interview subjects feel grateful, humbled, and honored. ${ }^{\text {xxii }}$ The expatriates' aforementioned awareness of their otherness — and the fact that these moments of grace occurred despite that—most likely amplified their impact.

Exemplar (Iraq): On that deployment I got promoted to major and I asked Lieutenant Wahid, my counterpart, if he would host the promotion ceremony. I told him my battalion commander would come. He was so honored and so flabbergasted that he had tears in his eyes when he told me that he would be overjoyed to have him and his brothers in the police force host the promotion. Actually, my executive officer went from lieutenant to captain, so we did a dual promotion together. So, my battalion commander flew and helicoptered in, did the promotion, and Pat. .. and I had Wahid pin us on.

They had put out an incredible spread of food afterwards. So, we all ate and drank tea and were merry for a time during a time in Iraq when things were not so merry.

Interviewer: In al-Anbar Province? Interview Subject: In the al-Anbar, yeah. ${ }^{28}$

\section{Adjustment and Acceptance (or, Learning to Swim)}

Exemplar (Japan): If you go overseas, do not stay with your own culture. Find a way to integrate with the new foreign culture. And in my case, it's not "Find a way to integrate." It's "Just dive in, because you don't have other options."

As already shown, adaptation to the new environment involved a series of observations and decisions. Two subjects used swimming as an analogy. When the expatriate learns to "swim

\footnotetext{
${ }^{28}$ Al-Anbar was the center of Saddam Hussein's power during his regime and of the Sunni insurgency once the regime fell. From 2003-2007, it claimed approximately one-third of American fatalities, more than any other province (Watters, n.d.). The city of Fallujah, site of the most famous battle of Operation Iraqi Freedom, is in alAnbar.
} 
with the current," he learns to adjust his own behavior to fit the environment, to achieve his highest priority goals (perhaps at the expense of lesser goals), preferably without compromising his principles or losing the core of his identity. Making these adjustments seems to get easier with time or repeated exposure. As the literature (and the interview subjects) recommend, if people engage with the environment and the culture, they do adapt. ${ }^{\text {xxxiii }}$

Exemplar (Cambodia): I think we try to apply North American rules when we go to these other places. We're like, "You know what, maybe if I just stand in line, everyone else is going to do it." I'm like, "No, that's not going to happen, all right?". And you, at some point you just realize, you give up, you're like, "I'm just going to do what they do. I'm not going to litter, and I'm not going to throw things, and that kind of stuff. I'm going to drive straight across the street right now because that's how it works." Once you stop swimming upstream, it becomes a little easier, but. ... Yeah, Cambodia, it was a great experience.

As noted in the sample data section, most of the interview subjects had significant contact with other cultures or sub-cultures prior to the assignment covered in the interview, and this practice at adaptation was most likely an advantage. Examples included short-term assignments in Europe and Africa, a year living in Thailand as a child, and a childhood split between Puerto Rico and New York, among others. Some ascribed much of their ability to work cross-culturally to that prior contact. ${ }^{\text {xxiv }}$

Exemplar (Korea): My first experience of this kind, I'd have to acknowledge the fact that my mom was from Mexico. . So as I grew up, it was not unusual for my dad from Iowa to pack us all up and fly to Mexico City.... They're actually a very different country and a very different culture. But we're not used to thinking about that. But if you live it, then you understand that yeah, your cousins, not only your cousins speak a different language, but they just look at life differently than the way you do. My mom was very much a part of that, and so she was the one who was able to provide all the context. My grandparents did for a number of years as well. If I was successful, I'm sure it had something to do with the fact that I was immersed in that type of a situation at a very young age.

Exemplar (Mozambique): I was awarded the award for most integrated volunteer. That showed me that my upbringing in the United States as an immigrant to a small Caucasian town in Pennsylvania, in the context of teaching me a sense of adaptability, has been my superpower as it pertains to going to other countries. It taught me that my differentness, my otherness was not a detriment. In fact, it was a gift. 
One way in which the interviews revealed the primacy of relationships was in expatriates' dependence upon other expatriates or upon host country nationals to help them understand and adapt to their unfamiliar environment. ${ }^{\mathrm{xxx}}$ These "life coaches," as one subject called them (host country mentors, in the literature) are vital to adjustment. The expatriate engages with the culture and the environment, but the life coach interprets the expatriate's experience and guides him or her on how best to react to maintain or strengthen relationships or achieve a shared objective. They help the expatriate find the truth behind the common misconceptions, cope with the uncomfortable moments, and multiply the moments of grace.

\section{Nature of the Work}

Ambiguity, Autonomy, Task Variety, Interaction With Elites, and Field Work

As some of the literature from several decades ago describes (Miller \& Cheng, 1978; Harvey, 1982; Mendenhall et al., 1987; Naumann, 1993; Birdseye \& Hill, 1995; Boies, 1999), assigned expatriate work is often marked by high role discretion (high autonomy), low role clarity (high ambiguity), and high task variety. ${ }^{\mathrm{xxvi}}$ The assigned expatriate is often the person at the overseas site who is most known and trusted at the home office. It becomes the expatriate's job to deal with the home office and to address some issues personally, as their representative. This may expose him or her to a wide variety of duties and challenges from representing the company to the government at the high level to investigating an issue or ensuring a policy is implemented at the lowest. At the low end, that ability to get out into the field and "make things happen" can become a source of satisfaction - to be able to see the impact of one's work. This is especially true for people who may have advanced beyond that domestically. ${ }^{\text {xxvii }}$

Coming from headquarters can give the appearance of authority and influence, which leads host country nationals to want to deal directly with the expatriate. This may be true whether the 
expatriate has formal authority or not, but it is especially true if she is in a managerial or liaison position. Consequently, the expatriate forms key relationships and often represents the organization to senior government officials and business leaders. For example, the pilot interview subject was a lieutenant colonel who dealt directly with South Korean Cabinet ministers and ate a meal at the Blue House (home of the South Korean Prime Minister), all because it was his job to deal the Republic of Korea government on a high priority project. Despite the fact that there was an entire U.S. military command on the peninsula, he became headquarters" "man in the field," a classical expatriate position. ${ }^{\text {xxxviii }}$ Of course, a position with high autonomy and one that may require representing the government to elites, requires an individual with judgment and intrinsic motivation. ${ }^{\text {xxix }}$

\section{Being the Bridge}

The literature and the subject interviews each cite a variety of typical roles for expatriates control, knowledge transfer, development, representation, etc. Two subjects summed those up with the same metaphor - acting as a bridge between the two cultures.

Exemplar (Afghanistan): My job essentially, the way I like to describe it, was essentially to be a bridge between ISAF NATO forces and the Afghan military, as well as the Afghan civilian population. I was acting as a bridge and/or conduit between these two worlds that were essentially trying to achieve the objectives of eradicating and/or suppressing the Taliban, Al Qaeda insurgency in Afghanistan.

The second subject to mention the bridge described a law that the government of Mexico implemented and the impact it had on their business. Mexico's federal tax agency began requiring a record of invoices, each with a 36-digit alphanumeric code, and a record of every corresponding receipt. Ignoring this requirement had significant tax repercussions. When the subject's information technology division back in the United States learned of this requirement, they saw it as impossible and nonsensical. They understood neither the source of the requirement nor the reason behind it. It fell to the expatriate to educate them and convince them 
it could be done and to convince the office in Mexico City that the headquarters was working to support them. ${ }^{\mathrm{xl}}$

\section{$\underline{\text { Building Relationships }}$}

For expatriates, effectiveness depends upon relationships. Relationships depend upon sincerity, respect, and finding commonality.

Exemplar (Spain): And when I went to Madrid, I mean, that was also a big one where my great-grandfather from my mother's side was a dude that was born in Spain. And that dude was. . . Fought on the Hispanic-American War for the Spanish side. They lost. And he decided to stay in the Island. He, I don't know, he liked a Puerto Rican girl and he stayed there. So being able to tell that story to the guy in Madrid, forget it. Right there, he's like, "Oh!. . . . And then you're from the South!" And then we were able to speak. I was able to connect that way. I think that helps a lot. And I was blessed in that way that I was able to speak both cultural languages.

Exemplar (Mexico): So I learn about the little different regional differences to the extent that when I'm at different places within the country, I can express about those differences and I can become more relatable, if we can call it that. And then the local people, they're-yeah, they're impressed. Like, "How do you know about that?" Like, "Eh, I know." So that helps a lot to break the ice and get business happening.

Exemplar (Afghanistan): There was no cavalry that would come and rescue us if something went bad. I depended upon my Afghan partners for my security and my life, really. That's building a trust based relationship and being sincere and convincing them through your actions that you're there to support them and that you do whatever it takes to make them successful whatever that is defined as. Whether it's getting money for a poetry contest prize or freaking going out, getting an aircraft to go out to the most remote places in the province that they couldn't get to because the Taliban controlled the roads. It doesn't have to be T. E. Lawrence-esque kind of things. I mean, just basic stuff like when I first got there, we were serving my Afghan counterparts tea in little paper cups. I wrote my dad and said, "Can you send me glasses, like little tea glasses?" He went to IKEA and got these little \$2 glass, tea glasses and saucers so that we could serve tea in a culturally appropriate way.

They would accept tea in a paper cup, but it's just little things like using a real tea cup and making a good green leaf tea, not Lipton bags from the [military dining facility], but actually going to the local market and buying real loose tea and brewing it in traditional fashion and all that. It goes a long way. Having sugar and whatever there. Just stupid little things sometimes let people know that you're genuine and you truly try to understand them. Even making a cultural reference to a famous Pashtun poet or integrating that kind of understanding into day to day conversations. 
Or being able to talk about the crops and the current weather impact on how things are going. It's a very agrarian society, they use the solar calendar. It's all based on the planning and the harvest and those kinds of things. I guess I was lucky in that a couple of my roommates and good friends in college were farmers and cattle ranchers or sheep ranchers. I knew a little bit about the right questions to ask about those kinds of things that when you're making small talk when you're walking a guy from the gate all the way into your office on a [forward operating base], you got something to talk about.

Yeah, you talk about your children. We talk about their family, to the cultural limit of what you can discuss. You let them know that you're real and demonstrate that that you have this personable side. You ask about their family, which is culturally appropriate. I mean, just little things. . . . Being a person of the book ${ }^{29}$ and being able to talk about some language and religious similarities.

Daud and David are the same name, essentially, and being able to just talk about those things in similar Bible stories that are found in the Quran and the Torah. It makes a difference. We are taught. . . not to talk about religion and not to talk about your family or little girls or whatever. You're just like, "That's what people talk about!" Learning a foreign language and going to another country and just going to the market, you just know, people ask what it's like. I'm like, "Dude, it's like going to Publix.". . . . It's boring life type stuff. You're not eavesdropping on the Queen of England or something. It's just boring day to day shit that people talk about.

Exemplar (Afghanistan): The power of culture, the power of language, the power of being genuine and even in. . Afghanistan is the place that everybody... When you say Afghanistan people are like "[scoff] Afghanistan." But even in the most difficult place like Afghanistan, you can connect with people that you understand culturally, you respect them, you come as a friend. It resonates with people wherever you go. Doing that in Afghanistan taught me that really, human beings respond to kindness, to. . . respecting the culture or appreciating who they are as individuals or being their friend. We were always worried about. . "What you should be doing for the elders." I said, "You know, don't worry. Bring your friendship." Come to my house; just drink some tea. They just wanted friendship. For me, for the work I did and what I saw sometimes was that we were so worried about trying to bring something to people and tell "Oh, we built this school here," or "We fixed your irrigation system." Sometimes, you don't even need to do that. People just wanted your friendship. That's all they were asking. They were not asking for a school. They just wanted you to care and know that they are there.

\section{Observation and Inquiry}

The literature discussed the importance of a learning goal orientation, and the interview subjects strongly concurred. One subject described being an expatriate as "endless learning,

\footnotetext{
${ }^{29}$ An Islamic term for members of the three Abrahamic monotheist faiths - Judaism, Christianity, and Islam.
} 
endless friction." The process of investigating what was really happening and why - even what people were really saying - was constant. The example above regarding the causes of ethnic violence in the former Yugoslavia showed that effective inquiry is another function of relationship. ${ }^{\text {xli }}$

Through observation and inquiry, and with the help of German nationals, one subject was able to identify possible corruption on the part of a low-level German official. Calling attention to that ended the official's resistance to a course of action that the German government had approved - one that would save the Department of Defense millions in fuel costs. ${ }^{\text {xlii }}$

\section{People Adapting to You}

When the relationship is established, host country nationals' willingness to adapt to or accommodate the expatriate - a kind of "reverse adjustment" - can positively affect the expatriate experience, especially when the situation does not allow the expatriate to be culturally sensitive.

Exemplar (Afghanistan): I know it sounds really stupid, but I didn't have a lot of time. I was under pressure to kind of move through and get certain things signed for that project, as well as a couple of other projects. When I swung into the office, usually you have to go through tea and you have to go through some of these things. So I told them I could not stay ahead of time. . . but I just needed to get those contracts signed. . . I went in, I said hello, we started signing contracts. As I was leaving, and this is literally 10 minutes later, the gentleman comes out and he goes, "I have for you, tea to go, we are faster than McDonald's." And literally, I had tea to go, my driver had tea and there was three boxes of fruit that I brought back. . . to find out which varieties taste better to report back to the [National] Arboretum... . I think that was something that was unique to the area that we were in. The Herati people are amazing. I know that I was lucky in that because they were willing to meet culture. They were interested in other people's cultures and they were willing to meet you.... It's only when you've already developed a trust with people where you can tell them this, that you can get five contracts signed and sent out to you. I mean, if I had done that off the bat, there was no way. You have to build trust.

\section{$\underline{\text { Local Methods }}$}

T. E. Lawrence, famous expatriate of the First World War, advised others working with Arabs to let the Arabs do things their way, because "under the very odd conditions of Arabia, 
your practical work will not be as good as, perhaps, you think it is" (1917). The interview

subjects also found value in local methods.

Exemplar (Afghanistan): Even today one of my big focus areas for my kids... [is] trying to get outside of the U.S. every couple of years for a vacation, just so they can understand cultures. Even developed cultures do things differently, right? I haven't been brave enough to take them to less developed places, but I think it's important to understand that we do have a great country, but people do well in other countries too, even if it doesn't look like it on the surface.... We are very lucky, but there's some really cool life lessons to be learned out there.

Exemplar (Israel): One thing that's been very memorable for me. . . is seeing there are countries that do certain things better than we do. Obviously, I knew that before. In the age of COVID, I think we all know it, and we did before. But getting out of that mindset of advise and assist — which obviously, there are things we're better at than the Israelis, for sure. But realizing that they built the world's best short range, counter-rocket and mortar system in five years from requirement to fully operational capable. They built the world's only combat proven active protection system for combat vehicles in five years from requirement to fully operational. Our modernization apparatus would, and is, taking 20 years to do the same thing.

\section{Theater}

Compared to many cultures, American culture places little value on "theater" - form over

substance. However, some subjects learned that, in service of the relationship, being seen doing something could be as important or more important than the act itself. Form could, in fact, be substance. ${ }^{\text {xliii }}$

[Regarding lessons learned during the assignment] The cultural ways of greeting people and talking to people. Very important. The importance of pomp and circumstance in certain places. Just protocol in general. The internalization of protocols of all sorts, whether cultural, or political or military. It was absolutely important.

\section{The Effect of the Expatriate Community}

One unexpectedly frequent topic of discussion among the interview subjects was the expatriate community. Other expatriates - even those from another organization or another home country - played an important role in the experiences of many expatriates. In some cases, they were an important part of the professional network. In others, they were an important part 
of the personal support network - not only in cases where they offered refuge from the host nation culture (as previously discussed), but in cases where they were experiencing the host nation culture together as fellow strangers in a strange land. Some subjects asserted that language skills and intercultural competence were as important in relationships with fellow expatriates as it was with host country nationals. ${ }^{\text {xliv }}$

\section{The Effect of External Events and Circumstances}

External events and relationships on the international scene affected the interview subjects' work and relationships with host country nationals in ways they would not have affected their relationships with coworkers in a domestic assignment. Examples included the conflict between Israelis and Palestinian Arabs, hurricanes in the Caribbean, and the tsunami in the Pacific. One military officer interviewed compared the effects of a non-combatant casualty with the effects of a Quran burning incident on his relationship with his Afghan counterparts. He and his unit had nothing to do with either event, but the first was very significant. The second had almost no effect, but he was forced to address it because his leaders assumed it would.

Exemplar (Japan): [The subject was a Chinese national at the time of her assignment.] The funny part is, there was a new technology at that time because it was still a little bit Cold War, the mindset or whatever. At that point in time, China didn't have that technology. They didn't allow it. So because I was somehow assigned to that team and I had to use and learn that technology, I had to sign a special agreement to say, I will not bring that to China. Later on, I noticed even today, if you look at the detail, Microsoft's latest operation system, it still excludes North Korea and everything. Of course, China is not excluded anymore, but back then, it's still excluded. So that was the first time I learned that there is a thick, thick wall between the Western world and the Eastern world. Japan is considered very much westernized. So, I guess that's also a way of motivation that this kind of opportunity, it doesn't come that often, so I better be able to study.

\section{$\underline{\text { Physical Well-Being Affecting Interactions }}$}

Some subjects noted that their physical and mental state affected their ability to work with

people cross-culturally, more so than if they had been in a domestic assignment with an inherently lighter cognitive load. ${ }^{x l v}$ 


\section{Challenge and Success}

All of the interview subjects related challenging situations during their assignment and how they addressed them. Many of those are related in this document. Several specifically cited that challenge as an important part of what made the assignment enjoyable and even made it a meaningful event in their lives. ${ }^{\text {xlvi }}$

I thought it was going to be really difficult. I thought it was going to be something that was very challenging, and it was, but it was the best deployment I ever had....I love being immersed in another culture and trying to figure it out because it's the hardest thing in the world. It's challenging like nothing else is. That definitely changed me for the better.

\section{Repatriation and Reintegration}

Repatriation experiences varied somewhat, especially as some did not really repatriate, but went from one assignment to the next. Nevertheless, as a group, the interview subjects descriptions covered every negative aspect of repatriation covered in the literature. Two coming from the developing world referenced experiences similar to a scene in the film The Hurt Locker. In the scene, the protagonist successfully survives a frenetic experience as an explosive ordnance technician in Iraq, only to be confounded by the number of choices in a supermarket cereal aisle.

There were also positive aspects of repatriation, which necessitated the creation of its own theme. One of those positives was that people's repatriation experiences improved with repetition. Another involved a then-Chinese national who had expatriated to Japan in the 1980s. She returned from the most technologically advanced nation in the world to a developing nation, but she returned to a special area within China that was allowed access to the world economy and modern technology, which eased her transition. People are also happy to be home with the friends and family they did not bring on their journey. If they were in straitened living conditions, they are happy to return to comfort, and even the ones who lived in luxury are happy to return to the familiar. They also come home with new skills and abilities. They had 
responsibilities and tasks overseas they never had at home, and they are stronger professionally for it.

However, many have missed opportunities at home, and their peers may have moved ahead in the interim. They may return to a far less interesting and challenging job where their overseas experience doesn't matter, as their employer wants to see if they can still fit in like a good cog in the machine. They may return to busy work or no job at all.

People will be interested in their experiences, but only up to a point. Their friends have no context for some of their most meaningful experiences, so they will now have to add others to their circle who do. The sudden loss of novelty, excitement, challenge, and status is jarring. For many, it can be a trigger for adjustment disorder and even depression.

\section{Table 18: Repatriation and Reintegration Themes}

\begin{tabular}{|l|l|l|l|}
\hline Name & Description & Files & References \\
\hline Repatriation and Reintegration & $\begin{array}{l}\text { The process of returning home and reintegrating into } \\
\text { home society and the sending organization }\end{array}$ & 19 & 107 \\
\hline Ad Hoc Reintegration & $\begin{array}{l}\text { Attempting to reintegrate with no formal plan or } \\
\text { program of support by one's employer }\end{array}$ & 12 \\
\hline $\begin{array}{l}\text { Poor Utilization of } \\
\text { Expatriate Expertise }\end{array}$ & $\begin{array}{l}\text { Utilization of a new repatriate in a position wherein } \\
\text { the expatriate assignment is irrelevant }\end{array}$ & 18 \\
\hline $\begin{array}{l}\text { Problems With } \\
\text { Reintegration }\end{array}$ & $\begin{array}{l}\text { Difficulty adjusting to home society and the sending } \\
\text { organization upon return from an expatriate } \\
\text { assignment }\end{array}$ & 17 \\
\hline Reintegration Positives & $\begin{array}{l}\text { Aspects of reintegration that the repatriate deems } \\
\text { favorably, i.e., beneficial to the repatriate, his or her } \\
\text { family, the organization, or the mission }\end{array}$ & 14 \\
\hline
\end{tabular}

Exemplar (Mozambique): Interviewer: What was your repatriation experience like after you came back home from overseas?

Interview Subject: Yeah, it was very difficult. Something like $40 \%$ of Peace Corps volunteers that come back to the United States suffer from depression. I did, for about eight months. It took me about eight months to get back onto my feet, because Mozambique taught me that the United States, and the culture that we have here, in many 
ways is extremely self-centered and it doesn't benefit the collective. American notions of time, value, worth, were all put into my face and brought to the surface, when I came back to the United States, and I realized that nobody really cared what my experience was in Mozambique, or when they asked the question, "How was the Mozambique?" They'd only give me no more than 22 seconds to answer. You feel a sense of loss when you come back, because there's also this idea of when you're in a place like Mozambique, as somebody who is an American and somebody who's different, you're put on a pedestal. When you come back to United States, you're nothing again. So that hurt, and it's hard to deal with. Being off the grid essentially for 27 months, made it really difficult to go back and work in a cubicle and live my life off of Outlook. It made it feel very insignificant, and made my life feel very insignificant. So, for those reasons, it was really difficult to come back to American life.

Exemplar (Tajikistan): Interviewer: What was your repatriation experience like after you came back home from overseas? Interview Subject: A, I didn't have one. B, The foreign service has a special category of leave which is called home leave. You are required to take 20 days of home leave between tours, between overseas tours. It is something that foreign service takes very seriously, so you cannot go from post to post....It's supposed to keep you grounded in being American, not just being an overseas citizen, not just being, not getting client-itis.

I have been doing this since '98. Maybe before that since I had an overseas semester in '97. I'm relatively comfortable with going to and from....It's difficult to forget you're American overseas since no one else does. I would say that it's not that difficult. You do get used to, "Oh where have you been mate? I haven't seen you in a while." "Oh yeah, I've been in Tajikistan." "Cool. So did you see that Cardinals game last night?" There's no context. There's no conversation. It's just, "Great. My kids go to the same grade school I went to. I have been going to the same bars we went to in college since then. You've been out doing things I have no context to discuss with you." So that's the only really difficult part. You become a different culture unto yourself. You have to learn how to expose people to your experience in a way that they're willing to accept, and not in a way that you might want to experience with them, especially to them.

Exemplar (Korea): There was crime when we weren't used to having it. All that stuff that you love about your own country.

Exemplar (Afghanistan): It was really difficult, again. It wasn't as much combat as Baghdad, or my first Afghan experience, but it was quite a bit. But then I got popped into Washington, D.C. after that, so it was like going from in the middle of nowhere, Afghanistan to maybe one of the most liberal cities in the world, or in the country, at least working at the Foreign Service Institute.

So it was a different. You had to really adjust. It was difficult, but not the worst one I've ever been through. Luckily, I had to go to a pretty good job working at FSI, so they kind of left me alone. And that was good. I kind of repatriated myself, I think. 
Interviewer: Did it make a difference for you that you were still talking about your experiences and still talking about Afghanistan at the Foreign Service Institute?

Interview Subject: Yes. Sure. Yeah, because, I mean, I was the only one there with a significant amount of experience in Iraq and Afghanistan. I taught the Afghan fam, or familiarization course and the Iraq familiarization course. I mean, I was an instructor there. I was one of many. But, in my office of employees, if they had been there, it had been, and not to denigrate them, it had been at a very high-level, like at RS [Resolute Support] Headquarters, or doing policy, which is fine. But nobody had the down-in-theweeds experience.

Exemplar (Afghanistan): I would say that it was difficult and it continues to be difficult. Because I'm always looking for a job that can give me that type freedom and that type of connection with people to do my work. My work even continues today to be humanitarian work and development work. To adjust to an office, to adjust to sitting down and discussing policy and. . you're missing the point. Anytime I get an opportunity to go into the field, to go and visit the different projects we have, I'm like the first guy on the plane. I'm like "Send me! Send me!" Because that's where I can express myself from and experience other people's culture and see the difference that we are making in that person's life. I would say the adjustment has been difficult.

Among the interview subjects, the young Army officer who went to graduate school in the United Kingdom narrowly dodged career damage that others in his program never recovered from. By spending his first two years as a commissioned officer in graduate school, he missed key developmental assignments (e.g., platoon leader) that would have provided the foundation of tactical and leadership training necessary for him to progress. However, he went into a special operations career field that allowed him to stay at the tactical level longer and catch up to his peers. The subject continues the story in his own words.

Exemplar (Israel): So then of course I came back, didn't really know anything about life inside my institution, aside from West Point, which is not the Army. So, my repatriation experience was actually pretty good. Came back in, went right into training and I made some choices in my career that allowed me to land effectively in the Army. Within two years after getting back, I could say, "Okay, I've successfully landed."

Some other people who did the same thing as me didn't, and ended up getting out of the Army after the minimum amount of time, because they were disappointed with--poorly managed, either by them or by their handlers'--integration process back into the Army.... I think they came back in, in the same situation as me and they did miss those foundational experiences. And then they were just thrown into some large staff that provided them neither the experiences that would be necessary to proceed successfully in their profession nor interesting and fulfilling challenges. So, I think they came back to 
commanders who maybe didn't know what to do with them. And were therefore just thrown at staff drudgery.

I think it's an instance of the larger organization [the U.S. Army] and not the one arm, West Point, which ultimately wants the prestige of these scholarships. There's nothing wrong with that. ...And also, genuinely, it's trying to believe it's giving a good experience to officers, but isn't in a position to guarantee you what the other end will look like....And I had sent some letters, making some suggestions about that. My main suggestion was just that the person's promotion would be frozen and they would come back and just be a day one second lieutenant. And the complaint was, "But then people wouldn't want to do it because they'd be two years behind their friends." Well, if you care so much about that, then just don't do it.

Exemplar (Afghanistan): My unit took me off the jump list and so they took back all this jump pay. I literally sat at home for two weeks and didn't do anything because I was pissed off that they took my jump pay, parachuting proficiency pay or whatever for the year I was gone. My ex was like, "You need to go to work." I'm like, "Nah. They took $\$ 1500$ from me. I'm going to sit here for two weeks and take an extra long vacation before I go back."

I called my boss the Friday before a four-day weekend and said, "Hey, I'm back in town." He's like, "Hey, yeah, don't bother coming in. Just come in and I'll see on Wednesday or Tuesday," or whatever the heck it was after the four-day weekend. I'm like, "Okay, cool. See you then." I think I dug some drainage ditches around my house... and just did some odd jobs there at the house.

Yeah, that was my reintegration then went back to a non-job. Really, the travesty of it was, according to the program, we were supposed to be Afghan subject matter experts when we were out of theater....But the Special Operations Task Force in Afghanistan worked for US forces to Afghanistan and did their own thing. [Receiving headquarters] had no involvement in it whatsoever. We didn't even track anything in Afghanistan. They didn't really care.

You have these Afghan experts sitting in a headquarters that doesn't do any Afghan stuff for 18 months out of tour.... To have them be in a headquarters that didn't do any Afghan stuff was kind of silly. It made your job really easy, because they didn't really care about anything, any experience you brought to the table. I did some investigations and would go to meetings sometimes. For the most part, my boss was pretty cool and just let me punch out early if there's nothing going on and didn't really care if I was there or not.

...I'm coming back in August of '15. People are like, "Are you new?" I'm like, No, I've been here for four years. I'm just coming back for deployment." Because people didn't know who I was anymore...it was a comedy. Good times.

Exemplar (Afghanistan): Two things: One, I had to make sure that I didn't go into over explanation or a simplified explanation of certain things and concepts, because English to English. But, at the same time, when that did happen, I found out that it actually 
improved my communications at the time because I found out that most of us have different definitions, and we assume that the other person actually knows what [we're saying].

That, and also, my speech pattern ... I would have to stop thinking. Right now, I know I'm speaking slower than I normally would because I'm thinking of Afghanistan, and I'm trying to make sure that everything's politically correct. Am I allowed to say that? So, I know I'm speaking slower than I normally would. But, that was the biggest adjustment, was to get back to a New York minute.

[Regarding work] experience, I actually was unemployed because I had given up my job, and it actually made it harder for me at the time to get another job where I lived, because - I was interviewed, so people could find out what Afghanistan was like, not because I-yeah. It really sucked.

But, I still volunteered. So, I had a very big adjustment in that sense, but it made it easier for me to be redeployed. So, that's why I got the second year [in Afghanistan], was because I became really good at working at that pace and working at Crazy Town.

My volunteer experience at the fire department is another job....And, that was difficult. . . I'll be very candid. We were under high stress, and unfortunately, I had a really bad call [domestic incident] outside of my house, actually, and that triggered PTSD....My neighbor's dog is a Dalmatian, and during that incident, I thought I saw Happy [a Doberman military working dog the subject knew in Afghanistan]....So, I know that I snapped. But, it made it easier for me to actually go back because, oddly enough, I do very well over there. But then, coming back for the second time after the deployment, just getting to a regular place of work from a 9:00 to 5:00 kind of thing, of what is normal, that adjustment was very hard.

I will say that the benefit since is that working with different cultures, particularly Middle Eastern cultures or, I should say, Islamic cultures, has been much easier. And the partnerships and relationships in the projects I work in now are certainly a benefit of...being an expat in Afghanistan. I don't think I would've been able to do what I do if it wasn't for everything that occurred, particularly during 2012 and 2013.

\section{Outcomes}

“Immersing yourself in another culture-it leaves a mark.” - Interview Subject

Outcomes, in this case, means the results of the expatriate experience, or what the expatriate brings away from the experience. The findings were derived primarily from text coded with the following themes. 
Table 19: Outcomes Themes

\begin{tabular}{|l|l|l|l|}
\hline Name & Description & Files & References \\
\hline Impact or Meaning & $\begin{array}{l}\text { Significance or value lasting beyond the assignment } \\
\text { itself }\end{array}$ & 17 & 66 \\
\hline Personal Changes & $\begin{array}{l}\text { Changes the expatriate experiences as a result of the } \\
\text { expatriate process }\end{array}$ & 19 & 119 \\
\hline Quality of Experience & $\begin{array}{l}\text { Positive or negative value of the assignment } \\
\text { experience, as perceived by the expatriate }\end{array}$ & 19 \\
\hline Relationships & $\begin{array}{l}\text { Expatriate's relationships with people during the } \\
\text { expatriate assignment process, especially with HCNs } \\
\text { during the assignment itself }\end{array}$ & 19 & 133 \\
\hline Importance of Culture & $\begin{array}{l}\text { The value of culture and language as they relate } \\
\text { specifically to expatriate relationships }\end{array}$ & 13 \\
\hline and Language & $\begin{array}{l}\text { Importance of language skills during the expatriate } \\
\text { assignment }\end{array}$ & 14 & 27 \\
\hline Value of Language Skills & & 29 \\
\hline
\end{tabular}

Outcomes shared by many or all of the interview subjects are as follows:

- Relationships that last a lifetime, and difficulty relating to those without similar experiences

- A broader, more inclusive worldview

- Profound appreciation for the impact they made or the lack thereof

- Increased empathy; more specifically, an increased ability to shift one's perspective to that of someone else, and an unwillingness to judge without considering circumstances

- Recognition of and gratitude for their privilege at home, as well as gratitude for the experience abroad

- Recognition that people are different everywhere in their circumstances and their culture, but they are still people. They want the same things out of life and are working in their own way to achieve those things, as best they can. In other words, expatriates are struck by the many aspects 
of human experience and human nature that we all hold in common. Paradoxically, one of those

common aspects is our differences.

Exemplar (Gambia/Afghanistan): [Asked if the experience changed her] Most definitely. Most definitely. I don't know how I would be different or who I would be if I hadn't had those experiences but I do know that those experiences led to other experiences. And I can't imagine who I would be other than an entirely different person if I hadn't had the collective of those times overseas. Or met the people that I've met. Because I think my closest community and the people I connect with most, whether it's every two years or every other day, are folks who understand that dynamic and who've had some of those shared experiences or at least experiences like that. So absolutely. Because it's, I think, set the course for life.

Exemplar (Mexico): But then once you go in, I mean, having the opportunity to spend time with people of different countries and learn about how many things we have in common as human beings, it was amazing....And I don't know, while you are doing this... because you're so close to the challenges of, "Oh my gosh, I need to come out with how to maximize efficiencies on a tax structure in a different country!", that it tends to cloud...the beauty of everything else. But as more time passes and you look back...you don't remember very well those things. You know they happen. But then...the friends that you made on the way. . . all this that stays with you for the rest of your career and your life...that's the best thing....The friendships are so invaluable. And you get, you keep in touch with them. Cannot keep in touch with them on a daily basis. But interestingly, I mean, all of a sudden after maybe a year or so without having an exchange, you, reach out to them, and or they reach out to you and, and we catch up really quick and we have a good time.

And also, you get to tell people. and [introduce friends at home to new foods and experiences]. I mean, it's not because you read it in a book. It's because I lived through it. So it does change you, it changes you tremendously....And I think it changes you for the good.

Exemplar (Afghanistan): The positive powerful ones were experiences where I sat with the local population. I interacted with them. I had tea with them. I had lunch with them. I spent time in their villages. We did these projects, and again, U.S. government, local official, local population... Seeing the effect of the efforts we are putting, the resources we have spent, and we're seeing change, opening of a football stadium. You sit there and. .. I'm so sorry....[pauses]

You see people's lives change. You see those changes and...those are powerful, as you can see. Then you unfortunately have, I mean I don't want to talk about it, but soldiers who you see and then the next day they're not there. Those are powerful negatives. Then you have powerful positives, the changes you make, and you see it right there.

Exemplar (Mozambique): [Regarding confusion over volunteer's motivation] Their idea was, why would you leave the place of plenty and abundance, and come to a place of 
scarcity, and live amongst us if you're not getting anything out of it? That line of thinking, that I was extremely privileged to even consider volunteering....Not everyone does know that they're as privileged as they are. And that's a real problem.

I learned the importance of power, the importance of water. The fact now that I never take any of those things for granted. Every time that I turn on my tap in the morning...I think to myself, "Thank God. I don't have to fetch water today." Even to this day I think that.

Another lesson I learned is that I was the worst language speaker upon arrival, Portuguese language speaker. At the end of my service, the director of the Peace Corps sat me down and he commended my language ability, and...I was awarded the award for most integrated volunteer. That showed me that my upbringing in the United States as an immigrant to a small Caucasian town in Pennsylvania, in the context of teaching me a sense of adaptability, has been my superpower as it pertains to going to other countries. It taught me that my differentness, my otherness was not a detriment. In fact, it was a gift.

Exemplar (Iraq/Mauritania): How did it change me? Beyond what I said already, I think it's helped me put things into perspective in life. And that's hard, I've become, I think much more interested and aware of the bigger world, whether it's on the international relations scene of interest or just on the cultural scene of different areas, and just becoming actually really interested. And then again, finding those commonalities of life. Watching parents trying to care for their children in the same way that are not in the same way I might, but in the same way of the love for their family or whatever. Just seeing different social spats between individuals, especially when we were training them. And especially when it's very hot and it's Ramadan, and they're trying to not eat or drink or do anything. And you're trying not to do it around them as well. And I think all those tiny little experiences really morphing and shaping my worldview.

Exemplar (Gambia): I do remember when we do kind of a close out ceremony, you kind of think back on your time. I remember thinking. . . that I thought I was going to go over and help people but I really made such a tiny impact. It was humbling. And so I told myself, well, "Focus on the change that you made for one or two people." Right? "You made some girls smile for a little bit and gave them a little place for refuge and you painted their nails. Maybe they learned to read a little bit." But in the scheme of things, was there societal change? Absolutely not. Was there community change? Probably not. It ended up being impactful to a few and was certainly most impactful to me.

Exemplar (Mauritania): There was one time we were down in the South, on the border of Dakar to the North, and one of the--the question came up, like, why do they live here? There's just nothing here. And then realizing that because of slavery, back in the day, in Dakar, this was an area they could settle... Just realizing those kinds of things, I think sticks with me. Really pivotal. One of the guys knew something about construction, and so out of raw supplies, in the middle of nowhere and just over the course of the couple of days we were there, he showed the locals a few things. And I think it was life changing for them. And that you sit back and just really realize, there's some points, moments in time where you realize like, what life in America is like, what it's like somewhere else, 
what it's like in that moment in time where those two worlds just meet and all that is running through your head as you're watching this, as I'm watching this go on.

Exemplar (Gambia): But I think looking back on it, years and years later, there are a lot of intangible skills and understanding that you get from a lot of. . . My partner will run the water in the sink and it drives me bananas to have the water running unnecessarily because not everybody has fresh water. So those kinds of things stick with you and it's different for everybody. But definitely experience that I'm thankful that I had. I can't imagine replicating or having that same experience now in life. It was certainly something that was suited for my 20 s before life really got off the ground.

Exemplar (Afghanistan): [Regarding the imminent shift of territory and personnel to the Taliban due to the U.S. drawdown] And to kind of bring it forward now for me is just like, you can't care more about somebody's country than they do. It may or not be the right....answer and no one's willing to listen to that, but you can't give a shit more about someone's country than they do. If they're not willing to do it, then I mean . . . Yeah, you can only do so much.

Exemplar (Afghanistan): Again, it's just taking the time to sit back and realize that most of the people there... are just trying to do the same thing you're trying to do back home, just in a different fashion, and maybe a different way, but families want to take care of their kids and make sure their kids have a better life than they did. They may want progress, but they don't necessarily want to go from third world country to first world country overnight. There's an education and a cultural process to get there. And if you do go too quickly, it could cause problems as well. But trying to solve some of those problems, and building those relationships to this day, it's one of those things that definitely stands out in your mind.

Exemplar (Serbia): I'm not sure what lessons I would have learned. I did start to understand. . . Actually, I have almost a visceral memory of this. This guy. . . And I was, what, 23, 24 at the time. And this young guy. He went to school in Canada, he came back and we were having this conversation. I'm like, "Dude, you guys can't stop fighting." And we're talking to the bar, right? And I didn't say anything like, "You guys are animals," or whatever. I just said like, "Dude, this shit's never going to end. You guys don't know how to stop fighting. You hold grudges for 500 years, what do you expect?" And I was kind of just dismissing the whole culture as like, "You guys will never stop, and this is ridiculous." And he's like, "You think you're not capable of this in Canada or the United States?" And I'm like, "Dude, we don't have these divisions." And now I look at what we have today. And I'm like, "Oh my God, we're like this close to becoming the Balkans."

So, yeah. It's interesting at the time you think you come from what you know, and it's normal, and when you understand those cultures, and you see how long they've been fighting, and you just feel like it's pointless. So the lessons and stuff, the things that I learned. . . I don't know if I learned it then, to be honest. But I started to become more aware of historical differences, and how deep seated those become, and the ethnic fractions and stuff. And that starts to play out in all my future experiences. I start to see that as the root of all issues... whether it be religion or a combination of everything. But 
yeah, that was a lesson for me, learning history, learning about those deep-seated divisions, and how hard it is to correct them.

My overseas experience definitely changed me....At that time I was a little angry at Kosovo. It started to make me bitter towards these populations that had the war and it's like...man, help yourselves, blah, blah, blah. And you. . . I think I was unfair to be honest. I mean, not as understanding as I should have been because people don't design their own situations in those, those environments and that's. . . You see this too. In Iraq, I remember people would be like "These people," and dude, they're just, they're just like us, man. When shit hits the fan and falls apart, they have to be a little bit more desperate and their opportunities aren't there. When you're younger you come up with this North American...dream.... You come from that mindset. If you work hard...you can make things happen, but if you try to apply it in places that are war-torn, that doesn't exist. If it was all about working hard, then that black lady in the Sudan carrying shit on her head for four miles, she'd be a millionaire.

You don't see that then. I know for sure at the time I was a little bitter...I would say I was unfair and not assessing the situation fairly for the people. You just become stressed by all the things that don't work and you blame that society for that. And you get just so fed up with the person cutting in front of you and not respecting your personal space. All those things just get on your nerves and you just blanket assess everybody. It's kind of not fair.

Exemplar (Bosnia-Herzegovina): Interviewer: What lessons did you learn from your experience during that assignment?

Interview Subject: To think from somebody else's perspective when living in somebody else's social world. To recognize that the things that you think are important maybe aren't. To never take for granted how lucky you are to have been born in America and grown up in such a safe, amazing place and [names sister] and I, whenever anything really horrendous would happen, we'd be like "Oh, beautiful, for spacious skies, for amber waves of grain", because it just was . . . You realize how lucky you are and that we all just take it for granted. And it's not granted.

Exemplar (Mali): That experience helped me because I have a...fuller life now because I've experienced something like that. And also...it makes me humble. It makes me aware. I don't know everybody's situation. I just can't broad brush people from one culture or just because they're foreign. I can't just paint them into a corner. So there's different motivations. I mean there's different intricacies in a culture, but there's so many things we share in common.

Obviously, it changed me because I'm a lot more open minded. And the thing is this, I mean in my service it's always been in the Marine Corps that we always had to be...charge the hill, type A personality... and use those type of personalities to tackle every problem, but that's not what I found. When we are put in the creative landscape or in an area we're meant to adapt, we adapt our thinking. Kind of like what Carlson did as the forerunner of Carlson's Raiders in World War II. He was embedded with the Chinese, but actually he was embedded with Mao Tse-Tung's army, which is considered non- 
standard...I really think it helps us because it changes us to be more open minded in our thinking and to be more creative at how we look at things. So, I think that my experience in the Marine Corps, it changed because of dealing with these types of cultural situations.

Exemplar (Iraq): I like to think it did change me in terms of I learned from my experiences. Any leader who continues to progress through the ranks in the Marine Corps should be doing that and hopefully growing personally and intellectually as well. I think that one of the things about that war was how close we were allowed to get, encouraged to get with the other culture. So I think that, if anything, it made me be much slower to judge particularly now that I'm a civilian when I might hear things on the news or hear the goings-on in the world about this people or that people, whether it be Iranians or Chinese or whoever doing something, to understand that you certainly can't lump everyone into one bucket. While that might sound very elementary, I tend to think that we as the American culture are quick to do that. My experience taught me to do otherwise or be otherwise.

Exemplar (Tajikistan): I'd say change in terms of my ability to interact with different cultures, to know different things about different places and different times and different cultures and religions. Not being afraid to say Assam Alaykum to someone or Inshallah. Just to drop that in conversation, to have been in rooms where a pod of the people will go from speaking English to French to German amongst four people who are from four different countries but all happen to know those three languages. It's just one of those things, where it's experience I wouldn't do without. It's definitely led to some career choices over time.

Exemplar (Japan): I think people may be different, but they can't all be right in their ways. I think that's why I travel to many, many countries. I always enjoy the culture. To be honest, we are all limited in our own view. We're limited from our own experience and the media we see, we hear every day, but there's so many things. Of course, if you're from a different country, you got interacted with very different, but [when] you experience on both sides, you understand both languages, you start to understand how the world is actually different. It doesn't mean one side is better than the other.

So, that's actually my experience from one country to another is more of, "Every single country is so different." All people are so different and all kinds of people have some sort of prejudice towards another people, for whatever, whether they want to recognize or not, simply because of the ignorance, they didn't know. They easily make that judgment or they thought they know. So I think that's pretty big, and initially maybe surprising.

Exemplar (Mexico): Oh my gosh. Yeah. It changes you in a way that again, you appreciate what's happening in the world....For example, something close to, all of a sudden, you see what's happened a couple of months ago, right? You saw what happened, what's going on in Madrid with the virus. Immediately, I remember my time in Madrid when I was going around a little bar, little bar with my friends. So it was like, "Oh my gosh, how are my friends doing?" Thank goodness all of them are okay. But you can immediately relate in a more personal way with what's happening in different areas of the world. Because you spent time there and you, you have friends.... When you have any 
kind of news, whether it's economic news or a military conflict or anything like that, that is close to a place that you have visited or work or were assigned to... then you can relate to why things are happening or how people are dealing with that.

Exemplar (Afghanistan): Not only did I gain an appreciation for other cultures, but...having deployed several times before, I may have interacted with locals, but I didn't have that level of interaction. It made me reassess how I engage with people and learn to appreciate their problems from their view, not just from our view.

One Peace Corps volunteer related how his fellow villagers found him dehydrated and

malnourished from Malaria - probably near death - and nursed him back to health.

Exemplar (Mozambique): I'll never forget that. I went to Mozambique thinking I was going to help them, but in the context of me getting so sick, they ended up helping me, and reviving me. After that point, I just remember thinking to myself, I'm just here for the experience, and if people learn anything from me, it's going to be based on just my exposure to them. You will hear this amongst other Peace Corps volunteers, this is the magic of the Peace Corps, is that you go into a community thinking you're going to save them and/or help them, when in fact upon the termination of your service, you realize that they're the ones that saved and helped you.

The single most important thing to eradicate ignorance, and prejudice, and racism is not through books. It's through sheer engagement and exposure....Living in a place of scarcity in Mozambique taught me that the most important things in life have nothing to do with material gains. It has everything to do with the relationships in which you forge in the context of scarcities. In essence, Mozambique was the best education of my life. Another lesson I learned is that geopolitically many things matter for a country to develop the way it develops. Those things being, its neighbors, access to water, its history, the language in which, in the context of Mozambique, colonizers gave them, the way in which a colonizing country left the country, once that country gained independence. All these things matter as it pertains to the development and/or the progress of a society in that country.

Yeah, I also learned that life's not fair, man. I learned that nobody gets to choose where they're born, who they're born to, the name they're given, and the religion they're born into. So, a lot of that is how we judge, how we understand other people, when in fact it's not even a choice that we can even make. So, Mozambique taught me that as well.

Exemplar (Mali): One of the more powerful experiences I've had...we had one attack [on a UN compound] outside the base. It was negative because of what was happening, but it was positive because we were able to bring everybody back. And quickly, it was amazing to see that all these different cultures, what we would consider our... competitors...come together to save human life and to rescue people that they didn't know.... Right in my UN Headquarters, I had Germans, I had French, I had Egyptians, I had West African nations, UN Romanian security personnel, and Chinese. And it was amazing to see everybody working together to the same goal. And that was one thing that really impressed me was, 
even though speed of information flow didn't happen as I liked...everybody was committed. I think that was probably the most powerful experience coming out of that mission.

...One thing I would like to share is...my interaction with one of the PLA ${ }^{30} \ldots$. He was a Chinese Lieutenant Colonel, young guy. His wife had cancer. He came to find that his wife had cancer and he was going to be leaving the mission....I mean don't know what his country's agenda was. It was irrelevant. But he was always smiling. He was motivated and friendly. And...he was trying to smile....I says, "Listen man. I wish this world would be different." I said, "I wish I could do something for you, for your family, whatever. I know it's just the way it is, but I'm going to pray for your wife." And in that country where religion is considered probably not apropos, he said to me, he looked me in the eye and he says, "Thank you for your prayers." And that was really shocking to me, the way his reaction was. He wasn't negative about it. It was like we were just human to human. And I think we understood that. And that was probably an exemplar of humanity.

\section{Discussion}

Having now discussed so many different experiences, the initial research question gains new salience:

RQ1. What are the distinctive characteristics of life and work as an assigned expatriate?

Among these varied expatriate experiences, are there characteristics common enough to be considered distinctive? To be sure, some experiences are relevant only to specific subsets. The high ambiguity, autonomy, and task variety that expatriates in managerial positions experience were not shared by the programmer in Japan. The Peace Corps volunteers in Africa and those serving in conflict zones in the Middle East and Central Asia experienced privation that those in Europe and Latin America did not. Nevertheless, many experiences were common, despite the fact that the subject sample skewed male and military and the location sample skewed developing world and conflict zone. Experiences of expatriate private sector managers in the literature which match the experiences of the male military members in conflict zones in this sample are external indicators of validity. Experiences of female, private sector, developed

\footnotetext{
${ }^{30}$ People's Liberation Army, the army of the People's Republic of China
} 
world, or non-conflict zone expatriates in this sample which match the experiences of the male military members in conflict zones in this sample and are internal indicators of validity.

The following experiences were truly common, and distinctive to life and work as an assigned expatriate:

1. Relentless learning. A new environment and especially a new culture demand it. Aspects of life once considered constant and requiring no thought are now in question.

2. The primacy of relationships. The success of the expatriate's work and the quality of his or her experience are utterly dependent upon them. Even the learning cited previously is all but precluded without relationships with reliable host country nationals. Relationships with the home office are almost as vital, and equally so for anyone in a managerial or liaison position. And the relationships formed in this new, stressful environment tend to last a lifetime.

3. Engagement with and adaptation to the culture and the environment. The tendency for an expatriate under stress may be to retreat into his or her shell, but that will most likely negate the purposes of the assignment and can lead to expatriate failure. Effectiveness requires adjustment. Adjustment depends upon adaptation of behaviors, attitudes and methods. Adaptation results from engagement. And without that engagement, the expatriate denies himself life-changing, breathtaking experiences unique to the host nation and this time in his life. Relationships are an effective catalyst here, also.

In a conference paper (Appendix 4), I previously published a framework for intercultural competence, also known as cultural intelligence. 


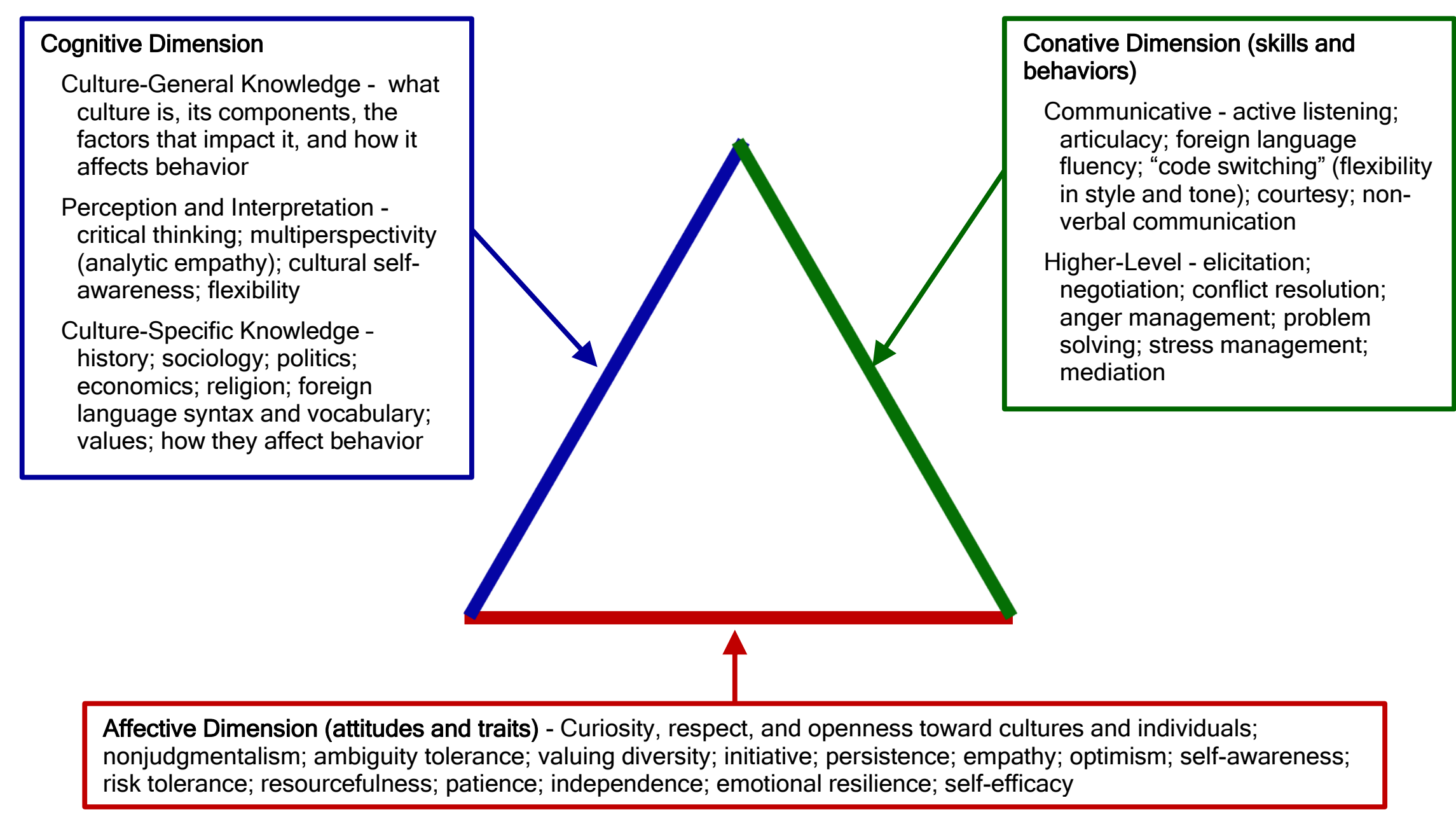

Figure 2: Integrated Model of Intercultural Competence 
to the three dimensions of intercultural competence.

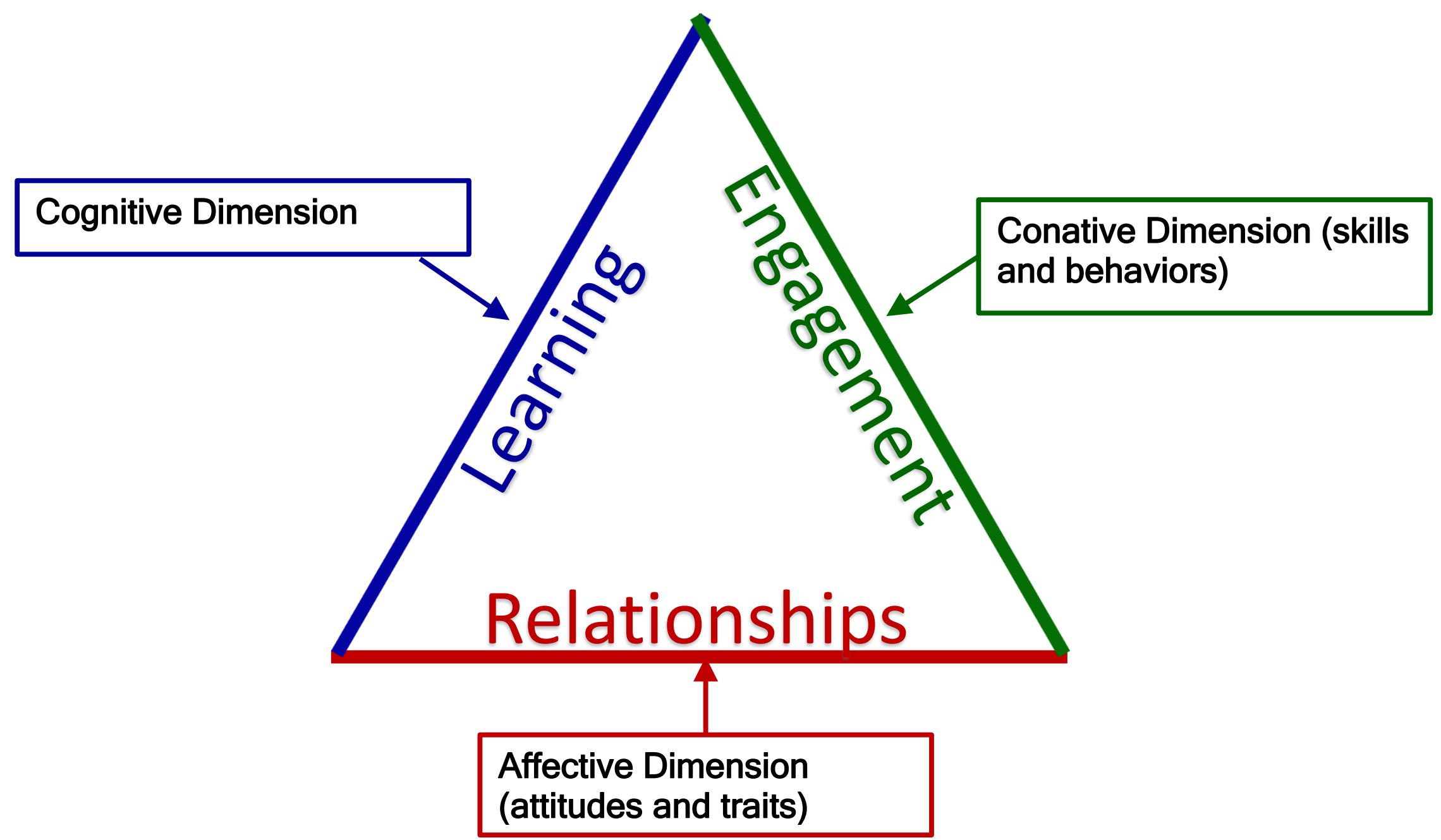

Figure 3. Intercultural Competence and the Assigned Expatriate Experience 
Having described what is specific to the assigned expatriate experience, we move to the second question:

RQ2. How do assigned expatriates perceive their expatriate experience?

Kraimer, Shaffer, Harrison, and Ren (2012) said that repatriates return home with a changed self-image - a different identity than the one they had when they left home. The reflections of these interview subjects support that assertion, but they also show that it does not go far enough. Based on the experiences of these 19 repatriates and their 26 assignments abroad, assigned expatriates perceive their experience as transformative. The experience changes their view of not only themselves, but of other people, of how the world works - even, as one subject said, of what it means to be human. Those changes together typically result in a change of lifepath.

To elaborate, all our experiences change us, but this change is so profound that the people who go through it see themselves as different people than they were before. They are more aware of the larger world beyond their nation's borders, and the events beyond those borders have a greater personal meaning to them. They have new tastes, new interests, and new abilities. They are more difficult to disconcert but easier to bore. Their need to see an impact from their work and to feel they are making a difference is greater than it was before the experience. They are more aware of and more interested in others' perspectives. Their own perspectives, on some things, have changed. They are quicker to connect with those with different life experiences and slower to pass judgment. They value relationships more. 


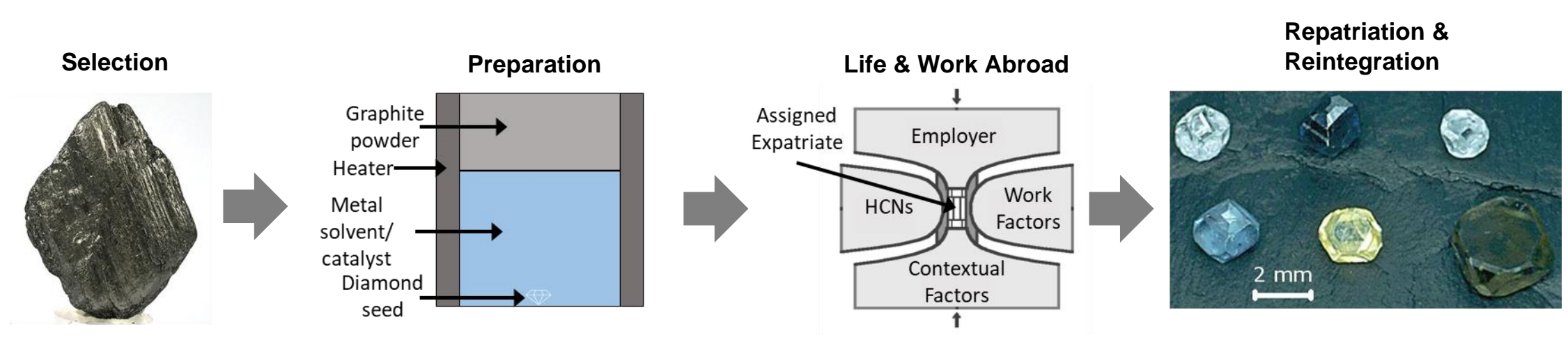

\section{Figure 4. Repatriate Synthesis ${ }^{31}$}

Graphite is essentially carbon. It has a myriad of industrial uses. It is found in batteries, brake linings, and pencils, and used for lubrication, steelmaking, and preventing nuclear meltdowns. Diamond is also essentially carbon, but it has a different molecular structure. Uniquely hard, refractive, and thermally conductive, it is as versatile as graphite. Diamonds are used as gemstones, but also as drill bits, abrasives, speaker domes, heat sinks, low-friction microbearings, wear-resistant coatings, and heat-resistant windows for lasers and x-ray machines. Industrial diamonds are almost all man made. They begin that process as graphite, selected for its purity, which then undergoes preparation for prolonged exposure to intense heat and pressure from all sides. At the end of this expensive, time-consuming process, the carbon is still there and has increased significantly in value. However, it is no longer graphite, and cannot be used as such.

\footnotetext{
${ }^{31}$ Going from left to right, images 1, 3, and 4 are from Wikimedia Commons at https://commons.wikimedia.org/wiki/File:Graphite-233436.jpg, https://commons.wikimedia.org/w/index.php?curid=1150106 (modified by author), and https://en.wikipedia.org/wiki/Synthetic diamond\#/media/File:HPHTdiamonds2.JPG. The second image is modeled after a schematic by De Beers, 2016 (recreated and modified by author).
} 
The expatriate experience can be thought of as a diamond making process. Selection and preparation are critical. The process is costly and slow, and it requires careful attention to detail. The end product is more valuable, but permanently altered. Sending organizations and prospective expatriates should anticipate these costs and these changes and plan accordingly.

\section{Areas for Future Research}

As I conducted these interviews, the most obvious source of areas for future research was my final question: "Is there a question I should have asked that I didn't?" The following potential topics resulted from that question, naturally from the research process, or from suggestions from professors. Most deal with new findings that came up in this research that I did not see in previous literature. The last half deal with the lasting effect on the expatriates from this experience as discussed above. This is reminiscent of a note from the literature review: "The literature to date is characterized by a dearth of methodologically rigorous research determining what development people achieve during their global assignments" (Lazarova \& Cerdin, 2007).

- Effects of COVID-19 pandemic on expatriation and organizations' choice to expatriate

- Moments of cultural dissonance and how expatriates react to them or work through them

- Effect of the expatriate community on expatriates' adjustment (enabler, refuge, crutch?)

- Empirical effects of expatriation on repatriates (e.g., psychometric testing before and after the assignment)

- Effect of cross-cultural experiences on repatriates' ability to deal with organization or industry sub-cultures (e.g., software development, sales, etc.) $)^{32}$

- Best uses of repatriates, given new capabilities (and new inabilities, or perhaps intolerances)

\footnotetext{
${ }^{32}$ For example, one interview subject remarked that working with the different subsets of the U.S. military's special operations community should also be considered cross-cultural work.
} 


\section{CHAPTER FIVE:}

\section{CONCLUSION}

\section{Final Thoughts}

Prior to this research study, there has never been any phenomenological study approaching this scope. Not one looked at the expatriate experience from beginning to end; not one covered so many assignments to so many different nations; and not one encompassed the experiences of expatriates serving the private sector, civil government, and the military. In retrospect, that should have served as a warning. However, this researcher failed to heed other warnings, so even if recognized, it is unlikely to have had any effect.

One positive aspect of this broad scope should be broad applicability. The original intent was to serve human resource departments conducting job analysis and design. My appreciation and respect for those who uproot themselves and serve abroad, which was already prodigious, has grown tremendously. Consequently, I hope that the results of this study will also serve prospective expatriates and their families by clarifying the expectations that the literature and the data concur are so important. To make that possible, I will work to widen its reach. 


\section{REFERENCES}

Abikhzer, C. (1999). Towards a paradigm for the use of best practices in expatriate management: A study of four canadian multinationals [Master's thesis, Concordia University, Montreal] (Order No. MQ43639). Available from ABI/INFORM Global. (304540054)

Andresen, M., \& Margenfeld, J. (2015). International relocation mobility readiness and its antecedents. Journal of Managerial Psychology, 30(3), 234-249.

Aquino-Russell, C., \& Russell, R. (2009). Immersion in another culture: Paradoxical experiences considered for teachers and students in university classrooms. Contemporary Issues in Education Research, 2(4), 77-86.

Arthur, W.,Jr, \& Bennett, W.,Jr. (1995). The international assignee: The relative importance of factors perceived to contribute to success. Personnel Psychology, 48(1), 99.

Baba, A. J. (2018). Cross-cultural communication imperatives. Critical Perspectives on International Business, 14(2), 170-187.

Barker, T. S., \& Cobb, S. L. (1999). A survey of ethics and cultural dimensions of MNCS. Competitiveness Review, 9(2), 11-18.

Biemann, T., \& Braakmann, N. (2013). The impact of international experience on objective and subjective career success in early careers. The International Journal of Human Resource Management, 24(18), 3438. 
Birdseye, M.G., \& Hill, J.S. (1995). Individual, organizational/work and environmental influences on expatriate turnover tendencies: An empirical study. Journal of International Business Studies, fourth quarter. 787-813.

Bhatti, M. A., Battour, M. M., \& Ismail, A. R. (2013). Expatriates adjustment and job performance: An examination of individual and organizational factors. International Journal of Productivity and Performance Management, 62(7), 694-717.

Black, J. S. (1988). Work role transitions: A study of American expatriate managers in Japan. Journal of international business studies, 19(2), 277-294.

Black, J. S., \& Stephens, G. K. (1989). The influence of the spouse on american expatriate adjustment. Journal of Management, 15(4), 529.

Black, J. S. (1990). The relationship of personal characteristics with the adjustment of japanese expatriate managers. Management International Review, 30(2), 119.

Black, J. S., \& Gregersen, H. B. (1991). When yankee comes home: Factors related to expatriate and spouse repatriation adjustment. Journal of International Business Studies, 22(4), 671.

Black, J. S. (1992). Coming home: The relationship of expatriate expectations with repatriation adjustment and job performance. Human Relations, 45(2), 177.

Black, J. S., Gregersen, H. B., \& Mendenhall, M. E. (1992). Toward a theoretical framework of repatriation adjustment. Journal of International Business Studies, 23(4), 737.

Boies, K. (1999). The influence of work attitudes on managers' intention to accept an international assignment. [Master's thesis, University of Western Ontario, London, Ontario]. (Order No. MQ42051). Available from ABI/INFORM Global. (304564004).

Brewster, C. (1988). Managing expatriates. International Journal of Manpower, 9(2), 17. 
Brewster, C., \& Pickard, J. (1994). Evaluating expatriate training. International Studies of Management \& Organization, 24(3), 18-35.

Cabral-Cardoso, C., \& Payne, R. L. (1997). Choosing A Project. IEEE Potentials, Potentials, IEEE, 16(2), 5-8.

Caligiuri, P. M. (2000). The big five personality characteristics as predictors of expatriate's desire to terminate the assignment and supervisor-rated performance. Personnel Psychology, 53(1), 67-88.

Caligiuri, P.M. and Phillips, J.M. (2003). An application of self-assessment realistic job previews to expatriate assignments. International Journal of Human Resource Management, 14: 1102-1116.

Caligiuri, P., Tarique, I., \& Jacobs, R. (2009). Selection for international assignments. Human Resource Management Review, 19(3), 251.

Caligiuri, P., Baytalskaya, N., \& Lazarova, M. B. (2016). Cultural humility and low ethnocentrism as facilitators of expatriate performance. Journal of Global Mobility, 4(1), 4-17.

Chiang, F. F., van Esch, E., Birtch, T. A., \& Shaffer, M. A. (2018). Repatriation: what do we know and where do we go from here. The International Journal of Human Resource Management, 29(1), 188-226.

Chen, H. F., \& Chiu, Y. H. (2009). The influence of psychological contracts on the adjustment and organisational commitment among expatriates. International Journal of Manpower.

Chen, G., Kirkman, B. L., Kim, K., Farh, C. I. C., \& Tangirala, S. (2010). When does crosscultural motivation enhance expatriate effectiveness? A multilevel investigation of the 
moderating roles of subsidiary support and cultural distance. Academy of Management Journal, 53(5), 1110.

Collings, D. G., Scullion, H., \& Morley, M. J. (2007). Changing patterns of global staffing in the multinational enterprise: Challenges to the conventional expatriate assignment and emerging alternatives. Journal of World Business, 42(2), 198.

Crocitto, M. M., Sullivan, S. E., \& Carraher, S. M. (2005). Global mentoring as a means of career development and knowledge creation: A learning-based framework and agenda for future research. Career Development International, 10(6), 522-535,586-587.

Dabic, M., González-Loureiro, M., \& Harvey, M. (2013). Evolving research on expatriates: What is 'known' after four decades (1970-2012). The International Journal of Human Resource Management, 26, 316-337.

De Beers Technologies UK. (2016). DPA petition on the proposed revisions to the guides for jewelry, precious metals, and pewter industries: annex 1, the technical properties and formation of synthetic diamonds. Retrieved from https://www.ftc.gov/system/files/documents/public_comments/2016/05/00069128099.pdf

Eaton-Magaña, S., Shigley, J. E., \& Breeding, C. M. (2017). Observations on HPHT-grown synthetic diamonds: a review. Gems \& Gemology, 53(3).

Erickson, P., Hassan M., Killian L. A., LaForge, G., Levit-Shore, S., Rhode, L., and Sholes, K. (2016). Lessons from the U.S. Civilian Surge in Afghanistan, 2009-2014. Woodrow Wilson School of Public and International Affairs, Princeton University. Retrieved from https://spia.princeton.edu/sites/default/files/content/591f_Final_20160208.pdf. 
Feitosa, J., Kreutzer, C., Kramperth, A., Kramer, W. S., \& Salas, E. (2014). Expatriate adjustment: Considerations for selection and training. Journal of Global Mobility, 2(2), 134-159.

Feldman, D.C., \& Thomas, D.C. (1992). Career management issues facing expatriates. Journal of International Business Studies, 23(2). 271-293.

Feldman, D. C., \& Tompson, H. B. (1993). Expatriation, repatriation, and domestic geographical relocation: An empirical investigation of adjustment to new job assignments. Journal of International Business Studies, 24(3), 507.

Firth, B. M., Chen, G., Kirkman, B. L., \& Kim, K. (2014). Newcomers abroad: expatriate adaptation during early phases of international assignments. Academy of Management Journal, 57(1), 280.

Froese, F. J., \& Peltokorpi, V. (2011). Cultural distance and expatriate job satisfaction. International Journal of Intercultural Relations : IJIR, 35(1), 49.

*Fukuda, K. J., \& Chu, P. (1994). Wrestling with expatriate family problems: Japanese experience in east asia. International Studies of Management \& Organization, 24(3), 36.

Galbraith, J., \& Edström, A. (1976). International transfer of managers - some important policy considerations. Columbia Journal of World Business, 11(2), 100.

Gertsen, M. C. (1990). Intercultural competence and expatriates. The International Journal of Human Resource Management, 1(3), 341-362.

Gibson, C., Hardy,Jay, I.,II, Baur, J., Frink, D., \& Buckley, M. R. (2015). Expectation-based interventions for expatriates. International Journal of Intercultural Relations : IJIR, 49, 332. 
Gomez-Mejia, L., \& Balkin, D. B. (1987). The determinants of managerial satisfaction with the expatriation and repatriation process. The Journal of Management Development, 6(1), 7.

Guthrie, G. M., \& Zetrick, I. N. (1967). Predicting performance in the Peace Corps. Journal of Social Psychology, 71, 11-21.

Haines, Victor Y., I.,II, Saba, T., \& Choquette, E. (2008). Intrinsic motivation for an international assignment. International Journal of Manpower, 29(5), 443-461.

Harris, H., \& Brewster, C. (1999). The coffee-machine system: how international selection really works. International Journal of Human Resource Management, 3, 488.

Harvey, M. C. (1982). The Other Side of Foreign Assignments: Dealing with the Repatriation Dilemma. Columbia Journal of World Business, 17(1), 53.

Harvey, M. (1989). Repatriation of corporate executives: An empirical study. Journal of International Business Studies, 20(1), 131.

Harvey, M., \& Novicevic, M. M. (2001). Selecting expatriates for increasingly complex global assignments. Career Development International, 6(2), 69-86.

Harzing, A. W. (2001). Of bears, bumble-bees, and spiders: The role of expatriates in controlling foreign subsidiaries. Journal of World Business, 36(4), 366-379.

Hays, R. D. (1974). Expatriate selection: Insuring success and avoiding failure. Journal of International Business Studies (Pre-1986), 5(000001), 25-37.

Graf, A., \& Harland, L. K. (2005). Expatriate selection: Evaluating the discriminant, convergent, and predictive validity of five measures of interpersonal and intercultural competence. Journal of Leadership \& Organizational Studies, 11(2), 46-62.

Hennings, J. A. (2018, August). What is intercultural competence and why is it important to business?. In 2018 Engaged Management Scholarship Conference: Philadelphia, PA. 
Available at SSRN: https://ssrn.com/abstract=3240922 or

\section{http://dx.doi.org/10.2139/ssrn.3240922}

Hennings, J. A. (2019). Methods of assessing intercultural competence for international assignments: a review. Unpublished manuscript.

Huei-Fang Chen, \& Yung-Ho, C. (2009). The influence of psychological contracts on the adjustment and organisational commitment among expatriates: An empirical study in taiwan. International Journal of Manpower, 30(8), 797-814.

Jackson, D., \& Manderscheid, S. V. (2015). A phenomenological study of western expatriates' adjustment to Saudi Arabia. Human Resource Development International, 18(2), 131.

Jordan, J., \& Cartwright, S. (1998). Selecting expatriate managers: Key traits and competencies. Leadership \& Organization Development Journal, 19(2), 89-96.

Kemp, L. J., \& Rickett, B. (2018). The lived experiences of foreign women: Influences on their international working lives. Gender, Work and Organization, 25(4), 343-360.

Kraimer, M. L., Shaffer, M. A., \& Bolino, M. C. (2009). The influence of expatriate and repatriate experiences on career advancement and repatriate retention. Human Resource Management, 48(1), 27.

Kraimer, M. L., Shaffer, M. A., Harrison, D. A., \& Ren, H. (2012). No place like home? An identity strain perspective on repatriate turnover. Academy of Management Journal, 55(2), 399.

Kobrin, S. J. (1988). Expatriate reduction and strategic control in American multinational corporations. Human Resource Management (1986-1998), 27(1), 63.

Lakshman, S., \& Lakshman, C. (2017). The dynamic change in expatriate roles: Strategy type and stage of internationalization. Management Decision, 55(8), 1770-1784. 
Lawrence, T. E. (1917). The 27 articles of TE lawrence. The Arab Bulletin, 20, 175-200.

Lazarova, M., \& Caligiuri, P. (2001). Retaining repatriates: The role of organizational support practices. Journal of World Business, 36(4), 389-401.

Lazarova, M. B., \& Cerdin, J. (2007). Revisiting repatriation concerns: Organizational support versus career and contextual influences. Journal of International Business Studies, 38(3), 404-429.

Lee, Y., \& Larwood, L. (1983). The socialization of expatriate managers in multinational firms. Academy of Management Journal, 26(4), 657.

Linder, C. (2019). Expatriates' motivations for going abroad. Employee Relations, 41(3), 552570.

Lobel, S. A. (1990). Global leadership competencies: Managing to a different drumbeat. Human Resource Management, 29(1), 39.

Mahajan, A., \& De Silva, S. R. (2012). Unmet role expectations of expatriates, host-country national support, and expatriate adjustment. International Journal of Cross Cultural Management : CCM, 12(3), 349.

McDonald, G. M. (1993). ET go home? the successful management of expatriate transfers. Journal of Managerial Psychology, 8(2), 18.

McKenna, S. (2010). "Adjustment" of the independent expatriate - a case study of doug. Qualitative Research in Organizations and Management, 5(3), 280-298.

McNulty, Y. (2015). Till stress do us part: The causes and consequences of expatriate divorce. Journal of Global Mobility, 3(2), 106-136. 
McNulty, Y., \& Brewster, C. (2017). Theorizing the meaning(s) of 'expatriate': Establishing boundary conditions for business expatriates. The International Journal of Human Resource Management, 28(1), 27-61.

Mendenhall, M., \& Oddou, G. (1986). Acculturation Profiles of Expatriate Managers: Implications for Cross-Cultural Training Programs. Columbia Journal of World Business, 21(4), 73-79.

Mendenhall, M. E., Dunbar, E., \& Oddou, G. R. (1987). Expatriate selection, training and careerpathing: A review and critique. Human Resource Management (1986-1998), 26(3), 331.

Mendenhall, M. E., \& Stahl, G. K. (2000). Expatriate training and development: Where do we go from here? Human Resource Management, 39(2), 251-265.

Mesmer-Magnus, J. R., \& Viswesvaran, C. (2008). Expatriate management: A review and directions for research in expatriate selection, training, and repatriation. In M. M. Harris (Ed.), Handbook of Research in International Human Resource Management, 183-206. New York, NY: Psychology Press.

Min, H., Magnini, V. P., \& Singal, M. (2013). Perceived corporate training investment as a driver of expatriate adjustment. International Journal of Contemporary Hospitality Management, 25(5), 740-759.

Minssen, H., \& Schmidt, S. (2008). Selbstselektion statt personalauswahl? auslandsentsendungen in der deutschen chemischen industrie**. Zeitschrift Für Personalforschung, 22(3), 228248.

Moon, H. K., Choi, B. K., \& Jung, J. S. (2012). Previous international experience, cross-cultural training, and expatriates' cross-cultural adjustment: Effects of cultural intelligence and goal orientation. Human Resource Development Quarterly, 23(3), 285. 
Naumann, E. (1993). Antecedents and consequences of satisfaction and commitment among expatriate managers. Group and Organization Management. 18(2), 153-187.

Oberholster, A. J., Clarke, R., Bendixen, M., \& Dastoor, B. (2013). Expatriate motivation in religious and humanitarian non-profit-organizations. Journal of Global Mobility, 1(1), 727.

Office of Personnel Management. (n.d.). Realistic job previews. Retrieved from https://www.opm.gov/policy-data-oversight/assessment-and-selection/other-assessment$\underline{\text { methods/realistic-job-previews/. }}$

Okpara, J. O., \& Kabongo, J. D. (2011). Cross-cultural training and expatriate adjustment: A study of western expatriates in nigeria. Journal of World Business, 46(1), 22.

Onosu, O. G. (2016). A qualitative analysis of the challenges facing expatriates coming to the united states. Journal of Behavioral and Applied Management, 17(2), 103-115.

Pate, J., \& Scullion, H. (2010). The changing nature of the traditional expatriate psychological contract. Employee Relations, 32(1), 56-73.

Perera, H.K., Chew, E.Y.T., \& Nielsen, I. (2017). A psychological contract perspective of expatriate failure. Human Resource Management, 56(3), 479-499.

Petison, P., \& Johri, L. (2008). Managing local employees: Expatriate roles in a subsidiary. Management Decision, 46(5), 743-760.

Phillips, N. (1994). Managing international teams. Irwin Professional Publishing.

Porter, G., \& Tansky, J. W. (1999). Expatriate success may depend on a "learning orientation": Considerations for selection and training. Human Resource Management, 38(1), 47-60.

Premack, S. L., \& Wanous, J. P. (1985). A meta-analysis of realistic job preview experiments. Journal of Applied Psychology, 70, 706-719. 
Presbitero, A. (2017). Religious expatriates' cultural intelligence and adaptation. Journal of Global Mobility, 5(2), 146-157.

Ramalu, S. S., Rose, R. C., Uli, J., \& Kumar, N. (2012). Cultural intelligence and expatriate performance in global assignment: the mediating role of adjustment. International Journal of Business and Society, 13(1), 19-32.

Ren, H., Yunlu, D. G., Shaffer, M., \& Fodchuk, K. M. (2015). Expatriate success and thriving: The influence of job deprivation and emotional stability. Journal of World Business, 50(1), 69.

Russell, R. C., \& Aquino-Russell, C. (2010). Expatriate managers: Powerful or powerless? The International Business \& Economics Research Journal, 9(2), 101-108.

Ryan, S. (2017). Rapport development and native language use between US advisors and afghan counterparts (Doctoral dissertation). Retrieved from: https://scholarworks.waldenu.edu/dissertations/3540/

Salgado, J. F., \& Bastida, M. (2017). Predicting expatriate effectiveness: The role of personality, cross-cultural adjustment, and organizational support. International Journal of Selection and Assessment, 25(3), 267-275.

Schruijer, S. G., \& Hendriks, M. (1996). Managers' life goals and their willingness to accept an international assignment. European Journal of Work and Organizational Psychology, 5(4), 541-554.

Selmer, J. (2017). "Expatriates: a thematic research history". In Research Handbook of Expatriates. Cheltenham, UK: Edward Elgar Publishing. 
Shaffer, M. A., Harrison, D. A., \& Gilley, K. M. (1999). Dimensions, determinants, and differences in the expatriate adjustment process. Journal of International Business Studies, 30(3), 557-581.

Shaffer, M. A., Kraimer, M. L., Chen, Y. P., \& Bolino, M. C. (2012). Choices, challenges, and career consequences of global work experiences: A review and future agenda. Journal of Management, 38(4), 1282-1327.

Shortland, S. (2018). Female expatriates' motivations and challenges: The case of oil and gas. Gender in Management, 33(1), 50-65.

Smith, M. B. (1966). Explorations in competence: A study of Peace Corps teachers in Ghana. American Psychologist, 21, 555-566.

Stahl, G. K., Miller, E. L., \& Tung, R. L. (2002). Toward the boundaryless career: A closer look at the expatriate career concept and the perceived implications of an international assignment. Journal of World Business, 37(3), 216-227.

Stroh, L. K., Gregersen, H. B., \& Black, J, S. (1998). Closing the gap: Expectations versus reality among repatriates. Journal of World Business, 33(2), 111-124.

Takeuchi, R., Tesluk, P. E., Yun, S., \& Lepak, D. P. (2005). An integrative view of international experience. Academy of Management Journal, 48(1), 85-100.

Takeuchi, R., Yun, S., \& Tesluk, P. E. (2002). An examination of crossover and spillover effects of spousal and expatriate cross-cultural adjustment on expatriate outcomes. Journal of Applied Psychology, 87(4), 655-666.

Takeuchi, R., T., Li, Y., \& Wang, M. (2019). Expatriates' performance profiles: Examining the effects of work experiences on the longitudinal change patterns. Journal of Management, 45(2), 451-475. 
Tsegaye, W. K., Su, Q., \& Malik, M. (2019). Expatriate cultural values alignment: The mediating effect of cross-cultural adjustment level on innovative behaviour. Creativity \& Innovation Management, 28(2), 218-229.

Tung, R. L. (1981). Selection and Training of Personnel for Overseas Assignments. Columbia Journal of World Business, 16(1), 68-78.

Tung, R. L. (1982). Selection and training procedures of U.S., European, and Japanese multinationals. California Management Review, 25(1), 57

Tung, R. L. (1984). Strategic management of human resources in the multinational enterprise. Human Resource Management (Pre-1986), 23(2), 129.

Tung, R.L. (1987) Expatriate assignments: Enhancing success and minimizing failure. (1987). The Academy of Management Executive, 1(2), 117.

Tung, R. L. (1988). Career issues in international assignments. The Academy of Management Executive, 2(3), 241.

Tung, R. L. (1998). A contingency framework of selection and training of expatriates revisited. Human Resource Management Review, 8(1), 23-37.

Vromans, P., van Engen, M., \& Mol, S. (2013). Presumed cultural similarity paradox. Journal of Global Mobility, 1(2), 219-238.

Waller, D. C. (2011). Wild Bill Donovan: The spymaster who created the OSS and modern American espionage. New York: Free Press.

Wang, L., \& Hinrichs, K. T. (2005). Realistic expatriate assignment preview: a potential solution to expatriate premature return. International Journal of Organizational Analysis, 13(3), 269-282. 
Wang, S., Tong, T. W., Chen, G., \& Kim, H. (2009). Expatriate utilization and foreign direct investment performance: The mediating role of knowledge transfer. Journal of Management, 35(5), 1181-1206.

Wang, C., \& Varma, A. (2017). Cultural distance and expatriate failure rates: The moderating role of expatriate management practices. The International Journal of Human Resource Management, 30(15), 2211-2230.

Wang, J., Chen, C. I., Liu, Y., Barkley, D., \& Wu, C. (2020). Intercultural competences and job satisfaction of expatriates: the mediating effect of positive psychological wellbeing. International Journal of Organizational Innovation (Online), 12(3), 140-155.

Watters, David T. (n.d.) Marine Forces Reserve Operational History: Global War on Terror (2004 - 2007). United States Marine Corps Reserve. Retrieved from https://web.archive.org/web/20120915231030/http://www.marines.mil/unit/marforres/Do cuments/GWOT\%202004-2007.pdf.

Wijerathna, M. P., \& Hewapathirana, G. I. (2019). An interplay between sri lankan employees and south korean employers: Conflicting priorities, attitudes, and cross-cultural perceptions in a 3-D workplace. The Journal of Business Diversity, 19(2), 123-138.

Wondwossen, K. T., \& Su, Q. (2017). Expatriates cultural adjustment: Empirical analysis on individual cultural orientation. Journal of Applied Business Research, 33(5), 963-978

Wong, A., Tjosvold, D., \& Liu, C. (2009). Innovation by teams in Shanghai, China: Cooperative goals for group confidence and persistence. British Journal of Management, 20, 238-251.

Wright, P. C., Geroy, G. D., \& Baker, N. (1996). Managing expatriates: A systems approach. Management Decision, 34(10), 32-42.

Zeira, Y. (1976). Rotation of expatriates in MNCs. Management International Review, 16(3), 37. 
Zeira, Y., \& Banai, M. (1987). Selecting managers for foreign assignments. Management Decision, 25(4), 38.

Zhu, J., Wanberg, C. R., Harrison, D. A., \& Diehn, E. W. (2016). Ups and downs of the expatriate experience? Understanding work adjustment trajectories and career outcomes. Journal of Applied Psychology, 101(4), 549. 


\section{APPENDIX 1}

\section{EXEMPLAR QUOTATIONS FROM INTERVIEW TRANSCRIPTS}

${ }^{\mathrm{i}}$ Exemplars of opaque selection processes: 1 . The basic vetting process was be competent enough to do minimally well in language school. I think that's about it. I don't know if there's any other details that went into our selection.

2. I've never really understood how they decided who went where. Was it a monkey throwing things up against a board? I'm not sure, but one day I went to somewhere, and it was like. . this is where you're going.

ii Minimal selection processes: 1 . After one conversation with the recruiter, I was essentially given a language test and upon successful completion of that language test, I was offered a role as an interpreter for the US military, and on a plane one month later.. . Because the language test that these companies would implement would be something like, 'Tell us about your favorite book. What was the moral of the story? Tell us about your experience in the United States.' So, they would ask fundamental questions as it pertained to understanding the way we could articulate ourselves, but they didn't ask us questions as it pertained to being useful as a matter of better understanding the insurgency, or the cultural nuances. They wouldn't ask questions like, 'How are Afghan and American cultures different or similar?' They didn't ask any of these things, but fundamentally that's our entire role. ... So, that's the thing about. . . these [linguist] companies ... They essentially were just trying to get as many people out in Afghanistan based on the surge.

2. In this case, I would say I was clearly selected due to language skills. When I came into the foreign area officer community, I was lucky enough that I already spoke Arabic pretty well. So they sent me to the Defense Language Institute to learn Hebrew, one of the lesser languages of our region. And so then when the assignment list came up, there was a job in Israel in it, and I was one of some very small number, if any, of others who spoke Hebrew at a high level. So that was why I got the job. Pretty straightforward.

iii Selection processes prioritizing international experience, foreign language experience, and soft skills: 1. I believe some of their criteria was my living overseas, working in the Peace Corps, having international experience. I think those were the main issues, the international experience and living overseas.

2. I think they were looking at somebody who's going to be open minded and someone who's flexible and someone who was. . . someone who had that experience in cross cultural environments.

3. And all I had to do is go and run to this office down there, and work with a bunch of military type guys. And he was like, 'You'll be perfect.'. . . I was the only person with a military background in the company, so he really was like, 'This is going to be useful. At least you'll 
know how to mingle with these guys.". Actually, I worked with him for three months in Budapest first. Working contracts with embassies, for moving diplomats and stuff. And he's like, 'I'm going to send you down. . . . You're good with people and you can manage things on your own.' So yeah, that was that.

4. They're also looking in general about how you can deal with politics and other situations. There's general interview curve ball questions. How would you do this? How would you do that? What if this happened? What if that happened? They're generally looking for flexibility and acumen and knowing when to press pause and seek guidance versus trying the best you can in a given situation.

5. [Explaining the degree to which exposure to foreign cultures was a factor in selection] I believe it was moderate, because I had already lived overseas alone and unaccompanied from my family from a young age. So, I was a boarding school brat. And boarding school. ... You are thrown into another culture. So is everyone else. There are people from different countries. Different languages are being spoken. . . . then my university education for my Masters was... in Scotland. I did spend a year working in England. ... it's not Afghanistan, but there are also cultural differences there too. ... So, my time abroad by the time I was in my 20 s was literally half my life. ... And the exposure to languages, studying different languages. The idea that I had already studied German was particularly beneficial, because the Dari word order is fairly similar. Some grammatical things are similar.

${ }^{\text {iv }}$ Recommendation-based selection process: I was selected through the reputational thing and the relationship thing. I already knew them. Yeah, I had to interview, but. . . even if I didn't do well on the interview, this guy's saying, 'Hire this guy. He's going to be fine for you.' So that worked out.

${ }^{\vee}$ Selection processes specifically assessing ability or desire to work within a foreign culture: 1. The application process, at the time, was quite regimented. It took 10 months from start to finish, from me applying, to me getting assigned. In between, during that trial, the Peace Corps did an over the phone interview, an in-person interview, a psychological test, and then a health test, and then gave me my assignment.

2. For [employer name], literally I went to an interview with the CFO and the CFO had no experience overseas--like no international experience whatsoever. I don't know how he got the job, but he had no international experience, and basically he interviewed me, and literally he asked about my technical knowledge in accounting, and I guess he was happy with that.

And then he asked whether I have communication skills other than English, and I did have that. And he tested that with somebody else, I mean he brought somebody else into the interview, and that somebody else, I guess, did some kind of cultural intelligence tasks or something along those lines and probed me in my Spanish skills or language skills. So, because I speak Spanish, I also familiarized a little bit with Portuguese. It's not that far away from Spanish and I guess because of that, somehow, I passed those tasks.

3. There was a written part of the application, I think, where I remember having to write why I was interested in it. What was appealing about cross cultural experiences? I know at that point having had two in particular, that had kind of lit the fire for me to know that I wanted to do more. I know a lot of folks go on from Peace Corps and eventually end up in a very similar career path that I've had working for USAID or other development organizations. So I think they end up finding a pretty common thread among people who want to be overseas and learning in that way. 
Yeah. And a lot of folks go over thinking they're going to make a big difference too. But hopefully the smart ones I think learn that they don't, that they learn more than they give.

${ }^{\mathrm{vi}}$ Use of language and cultural training exemplars: 1. Interviewer: How did your organization prepare you for the assignment?

Subject: They put us through. . . two weeks of cultural training specifically focused on the region where you're going to, and then a four month language course where we learn basic conversational capabilities of the local population. But. . the instructors were all native speakers, so they were able to contribute a lot to our ability to learn more about the actual culture.

Interviewer: What were some of your most powerful or distinctive experiences there?

Subject: I think powerful was using the training received. I'd say some of the great moments for me, but sometimes frustrating internally with the unit I was with, we were taught Afghans aren't going to make decisions right away. It's going to take a couple of meetings. A lot of times the priority of the location required quicker decisions. And trying to convince that, especially to some of the junior leaders who were there that, "Hey look, you're not going to get an answer today. You're not going to get a decisive answer. It's going to take three or four meetings or this one being more contentious may take a couple more." The victories were when things played out the way you wanted them to, even though they may have taken a little bit longer, but you expected with building the relationship with the local government personnel and military personnel, they actually did listen to you. They almost followed the cultural script to a T.

But at the same time, some of the frustrations were having to deal with the personnel who on the U.S. side who didn't want to wait or who were impatient. Some of the military people, special operations and conventional, really didn't always have that training or didn't care as much about the training and understanding of the culture, so they wanted answers quicker, and more Western style decision-making.

2. So I loved it, and I thought they prepared us fairly well. A lot of people hated it. That's because they picked the wrong people. But I thought. . . I was better prepared for that deployment than at any other deployment. Learning the language, even if I could only say, "I'm going to the bathroom," and "My mom lives in Austin, Texas," was a game-breaker, a gamechanger, and really helped me exponentially.

3. I'm actually trying to write a paper. . . about that question of what does language and so on really get us, aside from generalities about, "Well, it builds rapport." What can we concretely say that gets us? I would say it has, but I don't think I'd recommend it for everyone. First of all, we can't afford and don't need to invest that much. We need a small core of people who are specifically responsible for being the on ground relationship managers to have those skills. But others, like I'll give an example from Israel. There's a lot of U.S. engagement here, in Israel from a lot of different U.S. government agencies. And there are some who their technical knowledge is much more important. Like, say, missile defense guys who... It would be nice if they spoke Hebrew, but really their understanding of missile defense is the reason they're here, and rightly so.

... So there's different types of people who succeed overseas... . In my case, for example, I have to remember that I need to know a lot about cutting edge stuff about my own Army and my own command and what we're doing. If I don't know that and stay in touch with that, then all the cultural awareness in the world isn't going to help me do everything I should be doing. But I do think it's an enormous benefit. ... Israel presents foreigners with what it wants foreigners to see. 
And I don't necessarily mean that in nefarious way like they're hiding things or presenting things that aren't true; I don't mean that. If you can only engage with them in English, their entire inner life is in Hebrew. When they do--when they write or say things in English, it's inherently for a foreign audience. If you can see the things they write in Hebrew, and hear the things they say in Hebrew, you're accessing their unfiltered inner life. Even if they speak very good English, they're automatically in the externally focused mode. And I think that when you put them in Hebrew and you remove cultural barriers in that you present yourself as someone who knows how to wield all of their cultural norms. . . they're just going to be their natural self, whether they like it or not, because that's all they can do in Hebrew. . . . But even with all that preparation, obviously I still made cultural errors. I still have fallen on my face a couple of times culturally speaking. That just happens. And so, I think the one risk of getting a lot of cultural preparation is that you may acquire a hubris and forget the fact that you can never fully know a foreign society.

Culture-specific training exemplar: So, it was almost all culture specific. Generally, the foreign service is a pretty self-selecting lot. Culture general they assume you have. It really is culture specific. So. . . the Tajiks are one of the predominant peoples of South Central Asia. There are Tajiks in Afghanistan, there are Tajiks in Pakistan, there are Tajiks in Kyrgyzstan, some in Uzbekistan, but they don't like the Uzbeks very much. They tend to go to the southern border. That kind of thing, different religions, the history of the region, how they interact on the silk road, all that fun stuff. It's very culturally specific around South Central Asia.

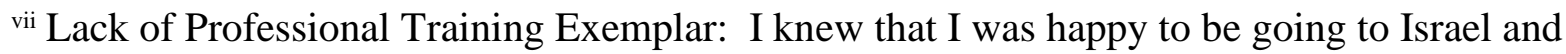
that I was interested to be working with the Israel Defense Forces. But I didn't really know much about the command I'd be representing. And I guess I didn't really know much about the nature of the work. Because of the in-region training and everything, I showed up knowing more about the country and its history, culture, current situation, security situation, armed forces, and so on, and language than the great majority, perhaps, of people arriving at similar situation. But I actually didn't know much about the job I'd really been doing. So, my expectations were positive on all the context fronts, but from a specific job, I didn't really have expectations.

viii Rigorous preparation exemplars: 1 . We stayed in a dorm and a studied Japanese day at night, basically nothing else, just study Japanese. So that was '91. And in '92, we were all sent to Japan, started in Tokyo for a few months, and they prepared us for the culture. So that place is all the foreigners, actually developing country foreigners and young, bright, very different professions. And they kind of prepared us for the culture for the first few months. 2. Well, Peace Corps does what is called in-country training. In the context of Mozambique. . . what they did was essentially, they took my entire cohort, which is made up of 72 people, and they flew us out to Maputo, in one plane. Then they took us to a nearby village by the name of Boane. They had each one of us stay with Mozambican families. One family for one volunteer, so 72 families essentially took us in and they were paid by the Peace Corps to essentially feed us and house us. During evenings and at night, we'd spend time with our families, but during the day they gave us in-country training. So, everything from Portuguese language training, to intercultural training, to site visits, to local places, to better understand the history of Mozambique, in preparation for our assignments, which would come once we got sworn into service, which would happen in December. So, during those three months. . you could think about it as an in-country boot camp to getting us prepared to be functioning once we got to our sites, outside of Boane, in villages all across the country. 
ix Private sector preparation exemplars: 1 . So in terms of preparing myself for what I will be facing, what happened was the CFO or my boss at the time, he says, "Carlos, gear up" a month after I was hired. "Gear up, we are going to Mexico City. I'm going to introduce you to the team there and you're going to get to know the key players." So, we spent a week together in Mexico city at the main office there. He walked me around. He said, "This is your office. It's going to be your office." I say, "Oh, cool." "And these are your team," and so I get to meet all of the team, the director of the country and all that. And then he left. And I was there. And that was the closest thing of an introductory training I got and the rest I have to make it happen.

[Second tour employer], it's a little more structured. [Second tour employer], they took a little bit more time trying to prepare me. So what they did I spend about a month or so looking at current processes, looking at my team, getting to know my team on a one on one, my team here in the US. Then I get to know from a theory standpoint, all the processes that. . . how the business took place, how the business interact internationally. And I was able to learn from here in the US in a meeting, training sessions that we got. The business model, as well as what are the challenges that we had.

2. [Serbia] So he just basically lays it out for me. I'm going to go down there and work with a couple of other Canadian guys, and we're going to set up all the different logistic routes and we're going to set up the contracts. And so yeah, he's like, "You're just going to run these contracts. We have all the ships coming into Greece. You have to do all the paperwork. So, you just explain what we would be doing. Plus, we'd be liaising with the customers, liaising with the host government, making sure that we have all the necessary paperwork." And it was interesting 'cause I didn't get any legal status whatsoever. I'm just going down there for the duration of my tourist visa, and then I'd pop back up to Hungary for a weekend, and then go back down. But they set me up at the house, set me up with a car, gave me a phone. And they said, anytime you want to come to Budapest, come up and hang out. . . . So, it was a dream job for a 22-year-old who didn't think he had any options.

x "Cookie cutter" exemplar: So anyways, the [military service] prepared us, obviously it's going through your medical screening, gear issue, basic cultural classes. They gave us a cookie cutter Task Force Southwest scenario. And that was incongruous to what my experience was laid before me in Mali. And when I went to get my gear issued the Marine Corp looked at it at a cookie cutter approach. And they issued me extreme cold weather gear for West Africa. And I had to take it and I had to mail it home to my wife. That was not the most pragmatic approach.

${ }^{x i}$ Combat advisor exemplar: Now specifically for geography, culture, history, language, anything like that, how much time was that and what did you do?

Subject: For Iraq as a [platoon leader] not a lot, but maybe a week or less, kind of the pointy talkie type cards, and very basic hand gestures or commands that you would need to do the job. It was pretty limited, maybe just very basic fundamentals of the cultural makeup. . . And I'm trying not to taint my comments from what I know now, but at the time it was just broad strokes. "Hey, there's these things called Shias and Sunnis and you're going to interact in this capacity type. So it wasn't really in depth, but that was about it. Maybe just a few anecdotal nuances of previous people that had interacted or trained with Iraqis in the past couple of years of the war. Interviewer: Were those anecdotes valuable?

Subject: I think so. 
xii "Survival" training exemplar: Basically, they gave us some training, let's say a week of training on how to shoot guns. ... how to drive a car fast. Then they give us this very nice training when you're embedded with the military. They sent us somewhere in Indiana for a week. . . . How to get on a helicopter, how to sit on a HMMWV, what happens if the HMMWV goes off-road, and hearing bombs and guns, we got that training. They gave us a week of training called Afghanistan Familiarization Course for one week. Those were the training we got. The bulk of the training was actually how to survive in Afghanistan in a conflict zone. Their cultural training was extremely weak.

xiii Combination training exemplar: So, agriculture, not only due to environment, but also for cultural reasons, agriculture is a process. I don't know how to explain it better, but it is a biological process by which we have food and fiber and water and all the resources that we need. And so, with that comes cultural interaction. And so, most of USDA training was to understand the agricultural culture of what farmers do, how they learn. . . There was an immersion exercise for an entire week, and that was to interact with expatriates of that country to better understand, to role play, and that's also part ... We were evaluated on that interaction. And also to whether or not we actually should stick to the correct assignment.

${ }^{\text {xiv }}$ Advocacy for in-country and team training: So there was a way to consolidate and be more strategic. And I think because of the way the government outsources the different training, it was all done by different groups. And so it was a fair amount of redundancy And I think on the job training would have been best done in-country. The only exception to that. . is when there were opportunities. . . to overlap with folks before they came out. . . Joint training, I think, is far and away the best option, when you can merge the different teams that will be working together wherever they are before they get to country or right when they're getting on the ground. . . Whatever your content is, I think that that relationship building can't be replaced.

${ }^{\mathrm{xv}}$ Self-preparation exemplars: 1. There's no induction training to go to Cambodia, and this is like 2006, I think, 2007. They have, sorry, you get like a little bit of briefing when you get there. Nothing that was that special. I did more cultural research on my own before I got there. I read the book Pol Pot. I read some other travel stuff just to get an idea. When we got there, I was kind of stunned by just how bad the security briefing was. They didn't even give my wife the security briefing, even though she's the one that's going to be out in the markets all day.

I found that to be poor preparation, but it was better in the sense that they had contracts in place to help you find an apartment. They helped you. You didn't have to fend for yourself so much. There was things in place already, so they helped you set up security at your apartment, so that was better that way. I was impressed with that.

I learned a lot of Cambodian, Khmer, and I could speak to the police. They freaking loved it. I mean, I would get pulled over on my Vespa. My wife on the back end, I would speak to them in Khmer. They didn't speak any English, so that's why I learned it. My wife and I, we hired someone to come to our house two times a week, and I was pretty damn proud of myself to be able to speak as much as I could. Although I could never like sit back and eavesdrop on people. That was never happening. I could pick up on words, but they would have to slow their speech down for me to be able to understand.

I made the effort and it did go well, especially with our driver pool. They didn't speak English very well. So I would speak to them in Khmer. It was good. I mean, I put a lot of effort into that place. Actually, I always try to learn languages when I'm somewhere like except in 
South Sudan and places like that. Even in Iraq, I tried to learn how to speak Arabic, but it's so difficult because we were popping in and out. It was just harder. Yeah, like in Hungary I learned Hungarian. Not a lot, but I learned, I'd say advanced tourist Hungarian. Learned a little bit of Serbian. German, I studied German when I was, so I've always tried to get languages that helped me on the ground.

2. I. . . didn't have any formal training there in terms of military training, but what I did to prepare personally for my job training, as my skill set, is I essentially started to memorize and learn words related to the military, in terms of rank and weapons.

I say this to you, because although I grew up speaking Farsi Dari, I only knew Farsi Dari as a matter of explaining my existence in the United States. Since I'd never served in the military, I didn't know that language, and whatever vocabulary. So, while I was in Kabul, a lot of the training that I did was to essentially acquire the vocabulary necessary to essentially describe insurgency, cross border attacks. . . helicopters. . or what the local term was for an Apache, or how the Taliban, or the insurgency, would describe IEDs, and what sorts of vocabulary they would use for it.

A lot of my in-country training in Kabul was about language acquisition. Then after six months, then I got assigned to the Marine Special Operations MARSOC teams, and I got transferred to Kandahar, and that's where I got military training. By the team there, I essentially was taught how to shoot a $9 \mathrm{~mm}, \mathrm{AK}-47$, an M4, 50 caliber, essentially got immersed into military life from the MARSOC teams down there. [Employer] didn't do anything. They essentially assigned me, and then whoever was interested in training me trained me.

${ }^{\mathrm{xv} 1}$ Learning orientation exemplar: I mean, I read a lot about Iraq. I read a lot about the history of Iraq, the history of the Arab people, the Shia, the Sunnis. I kept up with the news. I read a lot, so I just ... I'm a voracious reader, so I just self-studied and just learned as much as I could about what was going on there.

I would just say that. . . as horrible it was, I learned I was really good at this stuff, that I had an ability to communicate with people who are completely different from me.... That was fed by reading history and reading, reading, reading, and trying to understand what was causing this. I think that's something that I learned about myself in that deployment, and it was the springboard to me volunteering over and over again to do this type of stuff. ... what do I wish I had done before I left, I think that I wish I would have learned more about the population of where I was going. Who are the Shias that are in this area? But as we have a propensity. . . you just kind of know Sunni, Shia, and Pashtun, Tajik, Hazara blah, blah, blah, and the big hand wave.

xvii Interviewer: What adjustments did you have to make regarding life and work in your host nation?

Interview Subject (Mozambique): Well, I had to change everything. I had to change the way I thought about who I was there. I had to change the way I interacted with people. I had to change the way I had to speak with people. I had to change the way I thought about them. I had to think about ... I had to change my starting point, in terms of how I could better educate my students. I had to change my lifestyle. I had to change the way I communicated with my family. I had to change the way I interacted with the opposite sex, because of HIV/AIDS. I had to change the way I slept, because I had a mosquito net. I had to change the way I ate, because the way in which I processed and/or cooked my food every day was a long process. I just literally had to start a fire every day to make food. So, that changed the way I ate, and what I ate, and when I ate 
it. I pretty much had to change every aspect of my life from everything related to sleep, lifestyle, and communications.

xviii Exemplar (Afghanistan): I lived in a tent, but it was a tent that was in an open-aired, basically, mud compound that we were renting from a malik [village elder]. There was no running water. There were no bathrooms. There was nothing. There was an outhouse. .. Then, of course, we had a gym that we'd constructed for ourselves, but we did have an Internet room. . . and we had a little place to eat. But. . I always think about what war would be like. That was about as close as I have ever experienced. Living out in the middle of nowhere, far away from anybody. Nobody can come help you if you get overrun. Like they can provide air support, but you're on your own, so you better figure it out.

That's what it was like. It was in the middle of nowhere. There's about 8,000 people living in Ghorak. It was a really sparsely populated district, but it was right next to Sangin in Helmand, which is a horrible place, and southern Uruzgan, which is a horrible place. So. . . they call it a triangle of death. It was just, yeah, it was very sparse, but it was good. It was great. It was the best experience of my military career. It's that nothing's even second.

Exemplar (Gambia): The absence of anonymity was a real struggle for me. And so there would be some days when I would just lock myself in my little house and not open the corrugate metal door and not come out until like 3:00 PM when even everybody outside was like pounding on the door and wondering that I was okay, just because I needed alone time.. . . I think that was probably the hardest part. But the physical challenges were the easiest to overcome is what I found. Bucket bathing and pooping in a hole and all that stuff ended up just being kind of like, charming.

Exemplar (Cambodia): So my wife got to play more tennis than she ever played in her life. She loved that. She was taking lessons from a pro tennis guy in Cambodia. She's not on the circuit or anything like that, but he was an amazing tennis player and it was five bucks an hour. She's like, "This is amazing." You're stopping at a fruit stand. It's like a little side thing. There's some person with a cart. And this would be clean, because it's all shelled, right? But you get like a watermelon and people are like. . Yeah. My wife's like, "I want to go back right now."

ixx Exemplar (Kosovo): My most positive experiences I think were with the U.S. Embassy. Being invited to like July 4th, those expat type of events where you're included in something that's completely disconnected from the current reality that you have. So, you're sitting on top of a hill in Pristina, looking over the city, but you're in a U.S. Embassy compound, drinking American beer, eating American food. And there's American football on because it's Sunday. And they could live stream the football. It's like, "Holy crap." It was fun. And then they always had access to stuff, so they were always great that way.

Exemplar (Gambia): We would have computer access when we went down to the capital. And so, I would go down to the capital every six or eight weeks and just detox there. There was a Peace Corps house that folks would just congregate in to kind of feel American again. And that was a very, very helpful set up that they had there. And we could communicate with family a little bit more. Otherwise there was no communication.

Exemplar (Bosnia): One other thing was something that I think I learned in Bosnia that I think was incredibly useful in dealing with my future environments which was to always try to seize the day. Have fun anyway. Life's hard. These are horrible things you're seeing, but go out with your friends for dinner. Drink. Party at the internet café. ... We used to go almost every other weekend to the island of Korcula where my mom and stepdad had rented a house and it was 
beautiful. ... so swimming, going on the boat, learn to relax and enjoy it and that kind of highs and lows thing that I think helps you manage chaos.

${ }^{\mathrm{xx}}$ Exemplar (Israel): So, my living conditions, no complaints. Nice apartment, overlooking the Mediterranean in a nice neighborhood. Living conditions are great. I would say one thing that's probably worth mentioning in the context of your study, is that we made some choices in our living conditions, which put us more into the local community and less in the embassy community.... We chose to live in a neighborhood that's less the neighborhood where all of the expats live, and it's much more of an Israeli neighborhood. And more importantly, we put my daughter in the local kindergarten rather than in. . . . a very good American school here. And so as a result of that, all the parents and kids. . . we're dealing with are Israelis. ... .

That was a sacrifice in the sense that one thing that many people like. . - and understandably so - about expat experiences is the community of fellow expats, their fellow nationals in the country they're in. A lot of people like embassy life in that sense. For example, when we were in Oman, we were in fairly good touch with all that, and certainly did enjoy it and feel the benefits of it. But here. ... we just don't really live so much inside that world.

But it massively improved my cultural understanding and immersion. . . . I mean, I'm leaps and bounds more culturally aware, if I can use a generic term, here than I've ever been in any other foreign assignment. I can very seamlessly make jokes or use sayings that are drawn from deep places in Israeli culture. And that's useful to me, obviously, in terms of just relationship building and the reputation and presence I have with our partner nations. Even my daughter. . . I've learned a lot about Israeli culture, good and bad--or not bad, just likable and difficult from my daughter because she is demonstrating it.

${ }^{x x i}$ Exemplar (Mexico): I had an American Express card and I would just use it within reason of course, myself controlling the budget, I was pretty cognizant of that. But at the same time, I ate very well. . . and I had free healthcare. I mean, they pay for a $100 \%$ of my health insurance. So, I didn't worry about anything related to health insurance for me or my family at the time, no matter where I was. I mean, whether it was Spain, whether it was Shanghai, whether it was wherever, I didn't have to worry about that. So, to me, that was nice.

... At one point, I was in Cancun and I got a kidney stone and I was doing my job, and my gosh man, that was my first time with a kidney stone. . . I never had a pain so bad in my life up until that moment. ... And so I call the manager, and she takes me to the hospital. And of course, the company paid for the whole thing. So, me, from a health insurance [perspective], I was well taken care of. They took care of everything. . I mean, took me to the best hospital in town. So, living conditions were very good. I cannot complain.

xxii Exemplar (Morocco): I went to Morocco and lived with this lower middle class, Moroccan family in Fez for two months and studied Arabic immersively. And that was a very powerful experience with a lot of facets, which could be seen as the foundation of my interest in this region, which has continued to shape my career. But that was an experience of real. . living a very different lifestyle in a very different world. More so than I've done in any other instance, it's in every other overseas assignment I've been in some way, living on the grid of the U.S. government much more so than I was in this case in Morocco. In this case in Morocco, I was just not showering, going to the public baths instead, hanging out all day and all night with Moroccan twenty-somethings. Living in several different languages, French, Arabic. Seeing the social problems that affect twenty-something Moroccans in an in your face way, because of the 
family I was living with. Going on hikes near the Algerian border and getting questioned by border police and stuff like that. So that all was a very powerful experience, which has nothing to do with the overall UK experience, but a sub experience that had a big impact on me.

Exemplar (Japan): Even though we were not that rich, as I said, there were a number of volunteers and also there were people working in the same company. They liked to take us to places. I was able to go to more than 20 places from. . . north to Hokkaido to Okinawa to the south. Visited so many different places. I was able to see. . sumo and onsen [hot springs]. It was a very busy one year, for sure, but definitely, it was fun.

Probably the thing I most remembered was the volcano. It was a live volcano. Japan has--even Mt. Fuji is a live volcano. That was the first time I witnessed a live volcano not far from the place I lived. It's driving about an hour. And we all went there and experienced this. . . and nearby, there are a lot of onsen, the hot spring places. They're hot springs because of the volcano and at the same time they gave you the egg that was cooked from the hot spring. Because of the volcano. .. ash, [they have] a black color on the skin. When you open the inside, it's exactly the same. But they tell you, if you eat one, you get seven years longer, you live seven years longer. Who knows why? It's just a fun experience.

Exemplar (Cambodia): Yeah, it was a great experience. We enjoyed it and the UN treated us well. They paid our way in and out. Send you in on business class. That was my wife's first time in business class, flying from London to Cambodia. So, the whole experience was really fun. We spent so much time in Thailand diving. I mean, it was paradise. . . Because I worked so many hours, they had to give me comp time. ... So, I got two months off for free. So, we went to Thailand. I mean, I must've done 150 dives in Thailand. We loved it. . . It's crazy the neighboring country was the cherry on top for the whole experience.

I mean, Cambodia was amazing, too. Going to see Angkor Wat. Seeing something that most people will never see in their lifetime, because it's just out of the way, and there's other things to see. I don't know. That's the coolest part of all the life experiences you get, I think. And you know this, too. Even if it's a. . . terrible place, or it's hard, there's still some very redeeming sites to see things. And you're seeing things that most people will never see in their lifetime. So that's always the excitement, too. But yeah, Cambodia was pretty awesome.

xxiii Exemplar (Italy): And one of the things I learned in Italy was the kind of tremendous friction you experienced when you go into a foreign culture....For the first six weeks, I couldn't figure out how to buy food because every time I would go to the store, it would be closed. So, they had these hours that were like between these hours and these hours, and we're closed at lunch, and on Thursday, we're only open in the afternoon. And it's all these family owned shops because the system is designed to prevent...big chain stores from happening. So, all stores have to close during these periods. And so I lost a lot of weight because I didn't have any food to eat and I kept on trying to go to places and it was just very frustrating because you're... hungry, but there's no way to get food, and yeah, it was interesting.

...You know, then there was also the way that you dress. You know, Italians. So I grew up as a gymnast. I worked out like four hours a day, every day and I didn't really care what my clothes looked like....My whole world was about working out and studying, so I just wore like flannel shirts and jeans and stuff and I never really cared about how my hair looked or how my clothes looked or any of those things. And to the Italians, that's an insult, you know. You don't dress for yourself. You dress for others to make the world a beautiful place. So not doing that, I had to learn how to dress because I just never really thought about it. 
...And so I would go into the store and they would, I mean, first of all, the women would be just horrified by what I was wearing so they would immediately descend on me....And then they're like, no, no, no, no. Don't tell me what you want to try on, here, try this on. And so, I sort of changed how I dressed entirely and it was actually wonderful.

I guess I also changed how I ate a lot because just there was a system for how things worked. In the morning, I would go to this café, and you kind of stand at the cafe bar and you order whatever it is the Italians order. So, I would always have spremuta d'arancia [Italian freshsqueezed orange juice]... and then a brioche, like a little sugary Danish thing and a cappuccino, which you should only drink cappuccino in the morning. It's a breakfast drink with milk in it. Right? And espresso later in the day.

So that kind of like social breakfast thing is how they do it....I had my own café that I would go to. And then there's a group of people there and you have kind of warm, pleasant, nothing talk. People never talk about politics. They never talk about marriage. They never talk about sex. They never talk about anything. They talk about the weather and what you're wearing and "How was your day?" And it's all very light and warm and lovely, but it never goes beyond those topics. So that was very different.

Well, one thing that was that I made friends with a woman from the gym that I went to, and gyms are very unusual in Italy, because people don't work out. It's weird. You're supposed to relax and have a happy la dolce vita... I made friends with this one woman who was an aerobics instructor and it was just this really interesting experience to know somebody who was Italian, who worked at the gym, but also was so Italian. Like she would finish teaching aerobics and go outside and smoke a cigarette. And whenever I was on the StairMaster, I'm completely into it. I'm not talking to anybody. I'm at my highest heart rate. I am not messing around. And she's like, "Oh, ciao." It was profoundly interesting to see how you had to change your system to be able to function normally in the culture and be valued as a friend. You had to actually change. Even the things that were your goal, like working out right to rehab the ankle. I had very specific things that I wanted done, but I actually had to adapt in ways that probably weren't positive for the outcome in order to have friends and to be part of the society. And I think that was very profound. And then I guess the other stuff, I mean, I found all these friends who I've had for my entire life.

${ }^{\text {xxiv }}$ Exemplar (Israel): Well, one major adjustment was a cultural one. So, the U.S. Army way of doing things, or even more broadly American way of doing things, we don't think of ourselves as a particularly formal or hierarchical society. But in the military, we are, at least very much so compared to Israel. The Israeli military....It's very informal...including people who are much higher ranking than you. They're still in charge, they can still yell at you, but you call them by their first name. You are direct, you interrupt each other, you express your opinion very forcefully.... You feel less nervous about expressing a contrary opinion to a higher ranking person than you would in the U.S. military--much less. And you might do so very directly and less politely.

So, in the U.S. military, you might have a commander who is a good commander. He values contrary opinions. He wants to hear his subordinates disagree. But still you do it in a kind of, "Well, sir, I see what you mean about A, B and C, but the thing is there's also D which might." Something like that. But in the Israeli context, it's really much just more, "Nope, it's like this." And if you don't do that, you could be seen as weak. And if you make criticisms in indirect ways, which I might do in American context, and I would certainly do in an Arab context, you could be seen as even dishonest, like, "What are you trying to hide? Why won't you say it directly?" So 
instead of being seen as polite, that could be seen as obfuscating. So those are some cultural changes.

${ }^{\mathrm{xxv}}$ Exemplar (Iraq): Number one, it was combat, so the ever-present danger of the enemy trying to destroy us or the police. In terms of the geography and the climate - when we started, it was very cold and then within weeks it shifted to some of the hottest I've ever been. And then to the point where in two to three months of that time span, we would not operate for about two to three hours of the day (other than static surveillance) to make sure that vehicles wouldn't overheat, people wouldn't overheat, run out of water and rapidly dehydrate.

Exemplar (Bosnia-Herzegovina): Food wasn't very plentiful. There was no running water. You had to learn to mix your own hot water so you'd go home sometime in the afternoon when you knew that the water would be on and fill pots of water and then put them aside for your shower, either that night or the next morning. And then you'd have to boil some of the water and mix it all together and throw it over your head. So, that was different, and then you couldn't drink any water because they had blown up a lot of the sewage and water pipes... and when the water would turn off, it would suck down and that would pull both the sewage water and the regular water into the pipes and then push it back up, so if you opened your mouth in the shower, you got really, really, really sick, basically, so a lot of people were sick all the time. I had a terrible episode where I ate something, and I don't know what it was but I really got sick, like really, really sick and you were just always super careful about everything you were eating.

The other thing was the explosives that were everywhere. People had buried mines in the parks and stuff and not in a coherent way where people could remove them. So, you had to be really careful about never stepping off of a paved area and you became obsessive about it. But it was the right thing to be obsessed about because there would be explosions.

Then there was the way that ... so the way that the whole system functions....Everything was illicit.

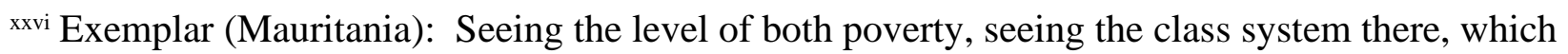
is insanely evident to include things like, if you're at the grocery stores, they have White Moors, Black Moors. Black Africans and White Moors were kind of at the top of this class system as described. And if you were not that, and you were in a line, the White Moor would come and shove everybody out of the way. And that was just accepted and having to just see that a lot and not react whatsoever, that was kind of an interesting thing.

Exemplar (Japan): Interviewer: What lessons did you learn from your experience during that assignment?

Interview Subject: I think it's more of an open mind. And the culture is a funny thing, even within Japan. People from Osaka area have a very different personality than the rest of Japan. So typically. . . if you live in Tokyo, you don't like people from Osaka, because people from Osaka are very direct and they're very calculative. So, when I lived in Japan in the south part of Japan and--every company, because it's a big company, they have a company doctor. So, the company doctor walks around once per week. So this lady is a retired doctor, actually. She's from Osaka. And the place I work is in the south part, and everybody actually kind of doesn't like her, and nobody wanted to talk to her, and we don't know, we're foreigners, three of us.

So, we really loved to talk to her. And she's old, she doesn't have many people to talk with. So from time to time, she took us to her house and treated us to some nice food. The first time I experienced the raw horse meat was at her place. I was like, gosh, that was so good. So, I saw that's funny as if, "You're all Japanese, why do you guys treat people differently?" Same as here 
in U. S., North and South people, but quite different personality and not talking about from vastly different country.

xxvii Exemplar (Mozambique): As a matter of culture shock, one of the most profound things that I saw there, that was new to me, was just the overt notions of what it means to be human, and let me explain. Killing animals, before your eyes, to eat the meal for the day. That was a new experience for me, even though human beings had always lived like this, in the context of living a privileged life in America, I had never really made the connection between chicken and beef, and that meat connecting it with an animal. Where in the context of Mozambique, if you're going to eat an animal, you actually have to kill that animal that day. In fact, in many ways, you're probably going to have a relationship with that animal before you kill it, like you'll end up raising it, and you'll give it a name. One day you'll get really hungry, and then you end up killing it, and eating it. That's one semblance of brutality that I mean.

Another sense of overtness of what it means to be human is, the relationship between men and women. Mozambican men, in many ways they understood their role as a man in direct comparison to the fact that they weren't women. What I mean to say is sexual dynamics between men and women were very overt. Men and women would engage in conversation, and interaction, and even in dance on a highly sexual basis, which was very new to me, because I grew up in the Northeast of the United States, and I was raised, and you're taught in the social system here in the United States, that men and women are equal. You don't talk to women with overt sexual objectives. There's like a little dance here in the west that we put over male and female relations. In a place like Mozambique, it was very obvious what was happening. In fact, it was just the way in which people operated.

Another thing that was really obvious, as a matter of human dynamics that wasn't essentially covered with a magic wand, was this idea of racial relations. People in Mozambique, the blacks, the whites, and the Indians, there were very obvious about pointing out people's skin color the moment they interacted. It was more of a matter of fact sort of thing. The Indian would say to a black person, "You're black, you're not getting in my car," or a black person would say to a white Mozambican coming from Portugal, "No, you're white. I'm not going to dance with you." It wouldn't lead to the same level of conflict that it would lead to here in the United States. What I mean to say is, all this to say, that these examples of culture shock showed me that there was a different way to essentially understand your place in a society, and there was a different way to express how those things came to be and what they were.

xxviii Exemplar (Tajikistan): My now-wonderful wife was over there. . . to go assess a program to set up women's and girl's centers funded by a big lobby in the UK. . . This group of street kids that were in the shelter put together a play about drugs and prostitution for street kids and what happens to people in their community.

It's something where our western values and her western values are setting up shelters and saying, listen if your husband is beating you, leave the house, go to the police, prosecute him and get out of there. That only works as far as you have a safe place to go to, and if your entire life isn't caught up in the family. When you live in your husband's parent's house and the kids belong to him and not to you, now going to the police and saying your husband beats you, is like, "Yeah, everyone's husband beats them, get over it."

Seeing your choices, if I leave my husband to get out of this abusive relationship, to get out of being beaten, it means my only options are prostitution or death. Because there is no other option. You're not educated. You can't read. You can't write. There's just so many fewer options 
and a lot of the things you take for granted in terms of our cultural ability to handle people that are in these situations. You can't just set up the model laws and the model situations for people without taking the cultural context in of, "Yes, but." Yes, we can prosecute [your case], but the police officers, first thing they're going to say, is, "Okay. If I believe you and your husband is beating you, if I take you away from that household, you understand that not only his family, but your family, the entire village, everyone else will completely ostracize you and you will lose everything. Is that really worth a black eye every couple of weeks?"

And that's a conversation that I never had to face and it was one that, being exposed to that and taking the decision down to the end point is something that I'd always kind of spoken of politically. I always use the example in the States of, if you say you want to do away with welfare and any other kind of supports and stuff, and yet you're not willing to talk about people dying on the street, then you're not taking it to end result. I always use the example of Ron Paul. Ron Paul: "I want to get rid of all government support." Great. People are going to die, Ron. "Yes. 14,332,412 people, I estimate, will die in the first five years." Okay. Now that is an intellectually consistent argument because he's taking it to the end point. Most people aren't willing to do that. And having seen that in front of my eyes in this play and talking to my nowwife, and she's doing this overseas. . . that really makes you think about where your ideals and reality interact and conflict.

${ }^{\text {xxix }}$ Exemplar (Mauritania): Even recognizing how my face reacts to things could have been, like "The whole meeting is going to go south now, because I recoiled at something you've said that has probably offended me, but may not actually be offensive." And in those moments in time, I lose sight of the broader thing that I'm trying to do there, the broader conversation. And sometimes those are just lessons that have to be continuously learned or retold, because I think it's easy to have that, "I'm an American official" coming back in your head pretty quickly. ... Were there times where I really felt like the ugly American? And my answer would be a very much, yes. In kind of how I reacted in those instances, I kind of alluded to that, really made for a good or bad day. And then what really, a lot of work retract, to retract that. I think, no matter what, there's still pride in who you are, what you're doing there, I'm an army officer, or I'm a foreign service officer. Like I have a lot of power. I can go to the ambassador and I can tell on this and this is going to happen, but then wanting to walk back, like that's a really ugly way to kind of feel the problem.

${ }^{x x x}$ Exemplar (Bosnia-Herzegovina): And I spent like three weeks trying to figure out how all the gymnasts must be discriminating against one another based on their names, because it's very clear who's a Bosnian Muslim, who's a Croat, and who's a Serb, and they were all on the team, and there was nothing. They were like sisters, and I couldn't figure it out. And then so I was talking to the coach one day and I said, who did you vote for? And she said, "I voted for Ali Izaat Begovich," who is a Bosnian nationalist. . . very anti-Serb, very anti-Croat, and not. . . into empowering little girls in leotards, because he's about. . . establishing a Muslim state. And it's really the opposite of what this coach would want. And I said, "But how could you do that?" And she said, "I know that when the Americans leave, he will have bought enough guns that it will never happen again. I won't be shelled every day for three years ever again. I won't do it to myself. I won't do it to my family. And I won't do it to my girls," meaning girls who were Bosnian Muslim, Serb, and Croat.

And it's one of those things where you learned that if you really knew somebody, as opposed to just asking them a question, you would get one answer from her if I had asked her that question 
and I didn't really know her, and a completely different answer if you had this level of trust that allowed her to tell you this without feeling like you were going to judge her for it. . . From the cheap seats, you can say "Oh, it's all about ancient ethnic hatreds", right? And that makes you feel better about yourself because you would never do this. . . There's something wrong with them and that explains why they would kill their neighbors, but that's actually not true. If there were ancient ethnic hatreds, everybody in Bosnia wouldn't have been living house to house, different ethnic groups. It would be like France and Germany, where they live on different sides of a border and that ethnic cleansing that brought that about in France and Germany didn't happen in Bosnia. . . But if you just have a cursory view of it and. . it makes you feel uncomfortable to recognize in yourself that all people could do that, then that's the outcome. A lot of American foreign policy opinions are based on those kinds of judgements. Whenever you feel that in yourself, that "They, the other, they're crazy. I'm better than that," that's when you should realize that you are probably misinterpreting everything that's happening in a way that is bad for policy, is bad for voting, is bad because you are misperceiving causes. Exemplar (Korea): There's this constant reminder of being in a, you say a war-torn nation, but what it really was, was you were constantly reminded of the tension between north and south. My housekeeper said it best. She's like, "No North Korea, South Korea. One Korea." In their minds there's this really weird separation between the two, but it's transient. In the long, long history of the people, this thing isn't going to last. For us, we're like, "Yeah, no. North Korea, South Korea. It's going to come to blows. It's going to be awful." It's not really like that. . . It's this thing, this awful family feud that eventually there's going to be a resolution. Everybody had to throw away your perceptions of what you thought you knew about Korea and to learn it firsthand.

Exemplar (Mauritania): [Asked what lessons he had learned through this assignment] Patience. A whole bucket of patience. I think learning to challenge my assumptions. Like I said, assuming that this experience would be the same, because these people maybe speak Arabic and have Islam as their main religion was a bad assumption. And really recognizing that, "Hey there's actually three sects of people here, and some are Arab and some are actually black Africans, how they classify it. And there's a whole different environment here." For me, it was no matter how much you study, it was "Living is the best teacher."

Exemplar (Afghanistan): I believe that the villagers are much smarter than the urban people. The urban people are the conservative ones. The rural people are actually... They were searching. They wanted opportunities. They might have come across a certain way, [but] "Don't judge a book by its cover." You see a guy with a beard and a turban and he's chewing his tobacco, but he was calling me on the phone and saying why I didn't put his daughter. . . We had a computer literacy program for girls in Shindand.

Interviewer: In Shindand? ${ }^{1}$

Interview Subject: Yeah. ... Two or three fathers called me and said "Why didn't you put my daughter in that class?" I was like, "Who?" I knew these people. They don't even say they have a daughter to you.

Exemplar (Israel): And then I had certain ideas about Israeli culture and what Israelis were like. Which turned out to be generally true, but missing a lot of additional things I didn't know. I came in with thoughts about how it would be working with Israelis and living among Israelis. And that was based on things I had experienced, and then things I had read and so on. I had visited the country a number of times. What I knew or expected, turned out to be true, but with major additions and even qualifiers or contradictory things that I didn't know. So for example, I knew 
that Israelis had a certain side of. . . being aggressive and to the point and even line-stepping-borderline impolite--with the purpose of getting things done, informality and things like that, which came largely from their Eastern European Jewish and Zionist pioneer history. What I didn't know about was all the things in the Israeli psyche that come from the Middle Eastern Jews. So it really constitutes $50 \%$ or more of the genetic cultural genes of the society. And that's the members of elite combat units, kissing each other as greeting. That's the extravagant hospitality. That's the music that people listen to and the food that they eat, and the sayings that they have. Much more than the last name, "Weinstein" type of Jewish identity that one might stereotypically think of in the United States.

Exemplar (Afghanistan): I learned that what happens on the ground, in a specific country, doesn't map or match to what's said about that country back home. You quite literally have to see it to believe it.

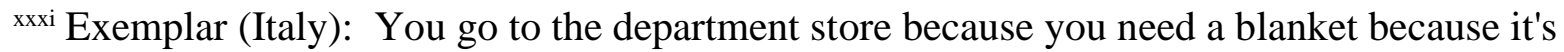
getting cold, and you go to the area where they keep the sheets and blankets and comforters and stuff and the floor is glass, and you look down and you're walking on top of Etruscan ruins. This society has been there since there was society and they don't just let people in which was, I think, a very interesting a thing to learn.

Exemplar (Korea): [Speaking of cultural adaptation techniques] The basis of that is do I know all these things, do I understand all these things? Well, I understand them from an outsider's perspective, but I certainly don't understand them as if I've lived them. You just acknowledge that, right? You're never going to be from there. . . . All I'm acknowledging is that to the extent that they can be learned, I can learn them. I always acknowledge that no matter how much study and how much I try to pay attention to those things that it's not going to be really the same as having been immersed in that culture from birth and knowing it firsthand.

Exemplar (Afghanistan): I think I really got good at dealing with Afghans and Afghan culture there. This was my fourth deployment, so I better have gotten better, but I think by that point I really understood what was going on, and I really dug deep into the culture and the history. So, I made adjustments to understand what was going on, and I could read situations better. I could read when they were just lying to me, which is fine, and when they were trying to play me, which is fine. I would do the same thing. No judgment. And how to, basically, maneuver through that area blindfolded.

That's what it is. That's how I describe it as. You have to maneuver through a minefield, cultural minefield, blindfolded. And you have to learn how to sense through that. That's how I would describe it. Because you can't - you're never going to see it completely because I'm a white guy from Texas and my Pashto probably hurts their ears. So, you have to learn how to go through something like that, and it's not for everybody. And then you really have to learn how to do it.

xxxii Exemplar (Iraq): For a long time we were on night patrol, which was more just unilateral, but in the mornings we walked through fields and other areas, and a lot of local people would give us flatbread and eggs for breakfast as we're walking. And it's just phenomenal.

Exemplar (Mauritania): And then how friendly and how welcoming the local population was. . . We were out pretty close to the border of Mali and of course, they're welcoming us, they want to cook food. And here was a big thing, we're all pretty hungry and then realizing that, okay, by cooking food, you mean you're going to go find that goat that's standing over there and then that goat is going to die. And then you're going to wait for all the blood to drip out of it, halaal style, 
and then you're going to cook it. So I'm going to sit here hungry and hot, six hours before I actually eat.

But I wouldn't trade those experiences for anything, because constantly those little experiences that clash, "Hey, this is what being an American has been my whole life, but this is what this culture is like." Here we are in this moment in time where they're clashing again, we're not on any clock here whatsoever, and this is going to take however long it's going to take. And that's just it. And we know there's going to be hours where we just sit here and do nothing and sweat. That's okay.

Exemplar (Iraq): Sitting down and eating with the Iraqi police is probably my most enjoyable memories. Marines and Iraqi breaking khubz [flatbread] together and drinking Iraqi tea, drinking chai. Two very different and distinct cultures and to see Marines who, by all accounts during the pre-deployment phase proved themselves to be miscreants and rascals, to be very fine and upstanding men when it came to representing the U.S. and Marine Corps and engaging with our partner force. And then a full appreciation for the hospitality and graciousness of the Iraqi people.

On that deployment I got promoted to major and I asked Lieutenant Wahid, my counterpart, if he would host the promotion ceremony. I told him my battalion commander would come. He was so honored and so flabbergasted that he had tears in his eyes when he told me that he would be overjoyed to have him and his brothers in the police force host the promotion. Actually, my executive officer went from lieutenant to captain, so we did a dual promotion together. So, my battalion commander flew and helicoptered in, did the promotion, and Pat. . . and I had Wahid pin us on.

They had put out an incredible spread of food afterwards. So, we all ate and drank tea and were merry for a time during a time in Iraq when things were not so merry.

Interviewer: In al-Anbar Province?

Interview Subject: In the al-Anbar, yeah.

Exemplar (Mexico): To me, the most powerful experience overseas was to learn about the culture. I mean. . . I did know, and you know about the different cultures in the world, but once you spend time with them, living with them, driving in a car around the city or around the country with people from other cultures, you get to appreciate the beauty of the culture. To me that was the most powerful thing. Nothing to do with work. I had the opportunity one weekend, and I said to one of my staff, if we could go to the pyramids, which are about an hour and a half from the city, Mexico City. We went to Teotihuacan. ... We spent the whole day at the pyramids. And of course, on the way, we got to talk about everything. Life, we talk about history, we talk about music of the country. We talk about, I don't know, I have to talk. Then, when I was there, we were able to go to a little town that's close by, because we were hungry. And so, I sat there and the guy comes to you and says, "Here's a menu." Although it was in Spanish and I speak Spanish, I couldn't understand what was in the menu.. . . . So, I did ask the guy, I was like, "Listen, do you have molcajete?". . . And he said, "Listen, we don't have it. But let me talk to the cook, to the chef." He talked to the chef, came back and said, "The chef says he's going to make it for you."

To me that was like, I didn't mean that. I was just asking. You don't have to. "No, no, no, no. He wants to do the plate, the dish for you. Don't worry about it." I was like, "Wow, thank you". I mean, these guys, these people are so awesome. So, he came back and is like, "Listen, the chef wants to know, how you want your dish. Do you want it with warm sauce, or you want it with eggs, and egg sauce? I was ,"Like, do you have any third choice for sauce?" "No, no, no. The 
warm sauce or the egg and egg sauce, they're the best." And I tell him, "You know what? Surprise me. Just let the chef choose. I'm cool with it". So, they did prepare it. I think they did it with an egg sauce.

The dish was awesome. We never ate that before, that type of sauce. It was awesome. And then the experience that I, that day, whole day from beginning to end, just being in contact with the people of different places around Mexico was amazing. It was awesome. Coincidentally, the same thing happened in Switzerland. When I spent a day, a weekend just going around the city and going around the country, it was awesome. Same thing happened in Madrid, nothing to do with work. He became my friend, the controller out there at the office who reported to me at the time, we decided to go around the city. And he came from a town called Zaragoza, a region called Zaragosa in Spain. And he told me that his family was very big about ham. And I was like, "What's big about ham? Just ham." He said, "No, no, no. This is special ham."

And then he took me to different places for me to taste what is called ham. And it's very expensive ham but very, very delicious ham. And then we spent a whole weekend, just going different little bars in different places. Just taking tapas, drinking what they call cañas and eating ham, and just spending time with people there. I mean, to me, those types of experiences, everywhere I went, Costa Rica the same thing, to me, those were the most powerful things because they allow me to, they open the door to what the culture is really, how the people are. I think it enriched myself as a professional, as a person, more than anything and helped me understand and appreciate that other culture.

xxxiii Exemplar (Serbia): Negative experiences, I don't know. There's a lot of negative, but I don't really have like this searing memory of anything too bad in Kosovo. Mostly it's just the traffic. It's just. . . You would be. . . The roads were brutal in the beginning. Most of them were bombed out. So getting anywhere was just, absolutely. . . It was just terrible. If you had to go across the city to meet somebody, it was brutal. It eventually got a lot better, but it's basically every single day you get into traffic. And that's my memory of that place, it was like just how bad people treated traffic. There was no rules. And it was me, me, me first. And whether it be an intersection, whether it be passing on the shoulders into oncoming. It's like, "Oh God, stop doing it." The traffic was. . .

Which is ridiculous, because eventually I ended up going to higher threat environments, like true high threat environments and stuff. And I look back and I'm like, "Eh, that was pretty easy." But it was my first embedded experience, where you're sent somewhere, and you're like, "Oh, this is interesting."

So, you only know what you know.... And the funny thing is, I saw way worse traffic in Cambodia or even worse, maybe. . I'm driving down and getting suicide bombed in freaking Baghdad. It's weird to even think about those things, but that's what I take away from Kosovo, because at the time, that was the most annoying thing that I endured. I was like, "What the hell is this?"

Exemplar (Cambodia): So, it's different. You come from this lily-white society in Canada or the United States. We have all these rules. You can't say this, you have to act this way. And over there it was like none of that ever existed. It was hilarious.

Cambodia is kind of, Phnom Penh was a. . . it's chaotic, I mean, traffic patterns there, you just give up on traffic there and you're like, okay, you don't follow rules and that's just, you don't even try. That's the other thing, I think we try to apply North American rules when we go to these other places. We're like, you know what, maybe if I just stand in line, everyone else is going to do it. I'm like, "No, that's not going to happen, all right?". And you, at some point you 
just realize, you give up, you're like, "I'm just going to do what they do. I'm not going to litter, and I'm not going to throw things, and that kind of stuff. I'm going to drive straight across the street right now because that's how it works." Once you stop swimming upstream, it becomes a little easier, but. . . . Yeah, Cambodia, it was a great experience.

${ }^{\text {xxxiv }}$ Exemplar (Mexico): I was born and raised in Puerto Rico. . . . It was a Spanish colony for 400 years until the Hispanic-American war, where Puerto Rico now becomes a U.S. territory. My grandfather was born a U.S. citizen. My grandparents raised me. So, I was raised by the influence of my grandfather, who fought in World War II and was very proud of what he did and was very proud for the U.S. country. All of that still encapsulated in a country in which the first language is Spanish and cannot ignore the Spanish influence for so many years. So that's how I grew up. I grew up listening and knowing I'm a U.S. citizen going back and forth. My mom was living in New York.

If we fast forward to when I was then given the opportunity to work with Latin America, I think it helped me a lot. . . being able to build the bridge between what is the U.S. culture and the U.S. history and having that pride, feeling that I am also a U.S. citizen. But also, it helped me understand the Latin American culture. . . which has a common denominator, which is Spain. I think that helped me a lot in terms of my background and the way I was raised unconsciously. I was not aware of any of that when I got into the job. But in retrospect if I look at it now. . I was able to have a good chemistry with my boss in the U.S. I was able to speak not only English, but speak the culture in the U.S. But then I hop in a plane, landed in Mexico City. I was able to also speak the Hispanic culture in Mexico.

Exemplar (Germany): [Regarding his initial expatriate experience in Germany as a young man] It started the process, I believe, of me expanding my understanding of how other places actually work. As an American younger person, you think you understand how the US functions. It doesn't mean you do, but you have that one structure, that one construct to work with interacting in other places that have different sets of rules on how things work, whether it's traffic or commerce or other things. It still begins that process of shaking up your understanding of what normal could look like, which I think somewhat reduces that. . . culture shock of then subsequent interactions in other locations being so different.

Exemplar (Korea): My first experience of this kind, I'd have to acknowledge the fact that my mom was from Mexico. My grandparents were from Mexico. So as I grew up, it was not unusual for my dad from Iowa to pack us all up and fly to Mexico City and go and spend a couple weeks in Mexico City living in a different country, being exposed to a different culture, language, all those experiences. That was kind of normal for us that we would be able to go and visit and be a part of that very, very frequently. Then as I got older, my grandparents came to the United States, to San Diego. But when we went down to visit them, we would inevitably find ourselves on the other side of the border in TJ, and you don't think about that.

Now I reflect back and, well yeah, because you learned how to do that when you were growing up, and that was just normal. . . That shift, because you don't really think of it like that, but the Mexican people, they have their own culture. ... It's totally different than it is in the United States. They're actually a very different country and a very different culture. But we're not used to thinking about that. But if you live it, then you understand that yeah, your cousins, not only your cousins speak a different language, but they just look at life differently than the way you do. My mom was very much a part of that, and so she was the one who was able to provide all the context. My grandparents did for a number of years as well. 
But if I was successful, I'm sure it had something to do with the fact that I was immersed in that type of a situation at a very young age.

${ }^{\mathrm{xxxv}}$ Exemplar (Korea): The reception center and the wives network in Korea, they've got a robust repository of knowledge. You can have as much or as little of it as you want, immersion in language and different experiences and culture that it makes it pretty easy to go and to get around, coupled with the fact that it's very permissive. It's very secure.

There was a guy that I was working with, his wife was native Korean. Happens a lot over there. Harvey's wife was my wife's Korean life coach. You have one or two of these individuals that are on speed dial. So, if you have a problem and you don't know the language, you call your Korean life coach and you hand the phone to them. They sort it out for you.

Exemplar (Iraq): My relationship with the interpreters changed over time and really leaning on them to be, not my cultural advisor, but yes, to a degree. . . . The nuances of, "Hey, don't ask them questions in this way. Don't ask, especially Iraqi officials questions in this way, because they're going to tell you what you want to hear. And that may not be what you're looking for. They're going to do all these things to save face and save honor."

Exemplar (Bosnia-Herzegovina): This was going to be my first experience working in the international community, so I was excited about it, and I also thought it would really facilitate my research for my Master's thesis. .. and then I was very saddened when it fell through. ... I was really just totally dejected that I had had this plan that was the ideal path and of course, I was going to get on the ideal path because I am very structured. ... I learned to swim, and I also learned just how arrogant it was of me to think that the environment would comply with what I wanted. When I talked to my Bosnian friend and she was, "Did any of your relatives, were they shot today? What is it that's so horrible that happened to you? Figure it out. You had a pretty good day."

xxxvi Exemplar (Serbia): Interviewer: What were your duties?

Interview Subject: Primarily, it was dealing with incoming project cargo and stuff. So, Kellogg, Brown, \& Root and stuff were setting up bases, and for, let's say, the support points and the support hubs in Skopje area. And they were getting ready. During that time, the Kosovo situation started to take off. So, my duties for say the year and a half, were to liaise with Brown \& Root, liaise with the Embassies, help them get all their cargo in. Anything that landed at the airport had to be customs cleared. So, we would do all the customs clearance. We managed an office of 10 to 12 staff members. And we would just divvy up. We had a project board of what was coming in, and we'd have to assign people to each project and make sure that they had all the paperwork going. And to make sure things were cleared and moving to their destinations. And we were the go-to. So, if the Embassy had something, then they would call us and say, "We have something coming in. Can you guys clear it for us?" Or, Brown \& Root would call, say "We have something in port down in Thessaloniki and we need you guys to clear it." It was lots of paperwork, lots of chasing, lots of follow up. It was interesting. But it was mostly project and project logistics, things like that.

And it was also a little bit of sales. So, any party, any wine society, any drink or get togethers, I would try to get myself invited to all those things, just to be in the mix with people. I took Brown \& Root guys. . . down to Athens, and I'd pay for it all with my boss's credit card. So yeah, just mostly project management and logistics stuff and then lots of liaising and sales as well.

Exemplar (Iraq): I think the other thing that I learned was having to put your helmet on and be a hardcore soldier, and then take it off the next second and give some candy to a child, or try and 
endear the population. That was probably obviously quite difficult, but over time got easier and better depending.

Exemplar (Afghanistan): I was provided three lines of guidance by General Mulholland. The first one was to assist the Norwegian coalition partners. . . to, let's say, work through their coalition restrictions for the betterment of the mission; [2] to the extent possible, help leverage CERP [Commander's Emergency Response Program] money and my engineering experience to still continue to do construction projects. . . . but also, to use that as a kind of. . . lever [to gather information], and [3] don't get dead.

So, those were the three lines of guidance to make sure that I wasn't off vector with my boss because I was functionally multiple provinces away, and he was a busy individual. I confirmed that I didn't have to get my missions approved by the Norwegian PRT [Provincial Reconstruction Team], by him or his staff members or someone else and he asked if I was unclear about the three lines of guidance. So, I shut up at that point and just was pleased with my latitude to operate. And I got on a plane and went back to Faryab and began to far more actively push out and develop and encourage a. . network - the NDS [National Directorate of Security] chief, the police chiefs, the governor, his chief of staff, and numerous other people to understand that AO [area of operations], to help understand what was really going on in that space. Yes, officially also have a couple of roughly $\$ 200,000$ construction projects, dams, roads, et cetera, that I was officially managing.

Exemplar (Mexico): Sometimes I needed to send team. And this happened very often, where we needed to send people from Mexico City because of their experience to, for example, a project in Costa Rica or a project in Honduras. So my job was logistics there, work with HR, at the time HR reported to me, so I worked with the director of HR to look at this and these people, they wanted to send these people, "How are we going to deal in terms of compensation? Where are they going to stay? How will things work out?" And then deal with HR issues, not necessarily in person, but the director of HR will ask my advice or my approval for certain things, right? For example, things that I can remember, that I cannot forget:

... We had some people working in Honduras when there was some kind of military issue happening in Honduras. And then we needed to get people out of the country. How we do that? I mean, would we charter a plane, or how are we going to do that? How do we work with the security of the team? Mind, the people that were working there, they were not from Honduras. So then, a fight broke out in a bar after hours between two of our staff. And one of them being from Mexico, what do we do? I mean, this guy, all of a sudden got very sick and we need to send them to the hospital and they need a surgery. How are we going to pay for all that? That type of stuff, that came straight to my desk and I needed to make the decisions or approve the decisions. One of the experiences that I also remember with [second tour employer] specifically is, I'm also responsible a little bit for the Caribbean. So, at the time there is a resort in St. John. It's just, not much happens there other than just the resort being what it is. But the hurricane, I think it was Hurricane Irma. And then after Irma, there was another hurricane I think was called Maria. So they pass through the Caribbean and they really damaged badly our resort in St. John.

... What are we going to do? We need to take the people out from there. And we were able to take the guests out, but now I have a resort. And it's an island that not many people live there. So. . . what are we going to do? I mean, because people are becoming desperate and our employees - and we got a group of employees that were staying at the resort, trying to keep the resort, put things in order, put things in place. So, it was interesting. That's something that I remember, we need to come up with a group of security and have a security team. 
We flew the security team to St. John so they could guard the resort while the resort had a water plant that will take water from the ocean and filter it out and all that. So, we were able to get water to the island. I mean, we contributed and donated to the island, but in a more orderly fashion, I suppose, because there were looters for the island and all that. So, we were able to establish the security team in place and get more order around the resort. And we were able to guard the employees. To me, that was one of the experiences to me that was interesting. I never had to do that before.

Exemplar (United Kingdom): I knew I wasn't going there as a normal student, that I was going there as a representative of my organization with little to no oversight or guidance from my organization. So it would be upon me to do that representing part in an environment where U.S. military officers were thin on the ground as best I could. . . My duties were to go to class and do well in the program I was in. And then also I felt duties from two directions, one from my institution, the U.S. military to, as I said, represent well. And by represent well I don't just mean avoid embarrassing the institution. I mean be a voice in the context of the British university that both reflected well, but also maybe contributed usefully to the conversation for all, from the perspective of the U.S. military. And then also, I felt beholden also to the scholarship, the Marshall Scholarship as an institution, to do my best, to get to know the UK, get to know its people and then stay in a mindset that would be positive for my return to the U.S. and rapid integration into a very different lifestyle and situation.

That's something I probably should have thought about beforehand. Yes, I did have experiences where the strong left wing, anti-war sentiments in British universities came to the fore, never in a way that were fiercely hostile to me personally. In fact, I never experienced that. Of course, I had good friends who shared those sentiments. Well, in 2008, 2009, the Israeli Hamas war in Gaza took place while I was at Kings college, London. And a group of left-wing students occupied university buildings in solidarity with the occupation of Gaza and ground life at the university to a halt for a few weeks. Not a full halt, but. . . So, seeing and dealing with all that was interesting. And then of course, I participated in some events that were about the Iraq war and so on where again, the general mood was hostile. So it was interesting to be in that environment. Of course, knowing that I wasn't going to speak for my institution, but of course, was speaking for my institution in some way.

Exemplar (Tajikistan): The biggest adjustment I had to make was, going from just being a [foreign service] spouse to. . . being one of the most senior, most experienced officers at post. Tajikistan was not and is not a garden destination for foreign service officers so it tends to be populated with a lot of junior officers. . . I kind of stepped right into a leadership role there. Being the only certified officer at post, you are given a lot of authority to say no a lot. Knowing how to wield authority and how to educate people in what they could and couldn't do with their money, including both uniformed and non-uniformed military assets in the region. It was a challenge, fun, very interesting, one of my most interesting tours.

xxxvii Exemplar (Afghanistan): And I know that a lot of things that we were doing was only temporary, just a band-aid for a sucking chest wound, but God, 2012, being a team leader in a district in Afghanistan where you're able to go out and execute missions and talk with Afghans every day and try to make some kind of impact, it was super rewarding. I mean, it was frustrating, the fact that, especially on the Afghan side were, through really no fault of their own, but they didn't know how their government worked and the fact I knew more about the Afghan's subnational government policy than they did and it was their damn country. That was kind of frustrating. There's that. 
Exemplar (Serbia): And then it's kind of crazy, you'd work your butt off during the day. And the memory of my first day, when we got in, when the bombing had stopped and we were going up, we went and got the house. We sorted ourselves out, and then there was no trucks around, but we had an Ilyushin 76 coming in from Texas, full of stuff for Brown \& Root, and for some other contractors. And I'm talking, I needed like 12 trucks for all the different flights that were coming. There were no trucks. I had to drive around the country. I started in Pristina, of course. And I'd say, "Is that your truck?" He's like, "Yeah." And I'm like, "Here's a hundred Deutschmarks, I'll give you 300 more tomorrow if you show up at the airport." And I had to do that all day just to find trucks, because nothing worked.

So, that was what was fun about it. And when it worked, and when you made it, how it happened, you're like, "That was awesome. Like this didn't exist and we made it work." And that was what was exciting about it, and I knew it was going to be like that. I knew the reason we were going down there is because stuff didn't work and we had to be able to improvise and adapt. So that was definitely. . . I'd say it exceeded my expectations. It was fun. It was a lot of fun. Exemplar (Afghanistan): I was glad as a. . lieutenant colonel to have the opportunity to go out and actually be on the ground and do work. Because in some circumstances, at least in my career field, the civil affairs captains are the guys on the ground doing stuff but they're also the guys fresh out of training. . . and having 10 more years experience behind me in other countries. . . I felt like I could make a bigger difference on the ground than I could sitting behind a desk.

xxxviii Exemplar (Mexico): I thought. . . most of the total work was going to be accounting at my desk. Very boring, I'll do the entries, run the reports, present that to somebody and then that was it. That expectation became an illusion really quickly... . I mean my work evolved in a way that I became the legal representative for the legal entities in Mexico. I found myself in the board of directors of a joint venture with our government agency to promote economic growth in the rural areas. And we were providing the software and the government loans and stuff.

So of course, in order for me to negotiate effectively, I needed to be there. It's something that, it's very related to the culture. I mean you, I'm just going to tell you, I mean, if you go and you have a meeting with the counterpart and then this meeting is over a couple of drinks and you have a dinner and you share more than just business, you established some kind of common ground, or you hear what's happening. You listen to what's going on. You share stories. Things just happen, because all of a sudden, you're not this foreign guy that come from another country and then goes away, and you never see him again, you become part of the whole story of what's happening

... I had to. . . fly from Mexico City to San Jose, Costa Rica for a press conference. And I had to spend my time there and meet with the president of the Central Bank of the government there, just to get the business, like a real [signature]. And we were able to sign a deal with Banco Popular back then because of that. And then from there moved to Dominican Republic just to go to Madrid, and because you have to get things happening and things happen, at least in my experience, when you are there in person.

Exemplar (Serbia): But I was kind of like Country Manager, something along those lines. . . I was excited that I had an opportunity to go work with a company that was legit because they had legit customers. They were working with big boys like US Embassy. I was dealing with the US Embassy, three times a week. And I was actually. . . There's an ambassador, I don't know, you probably know him. Chris Hill. So, he was a big shot, he did the Dayton Accords and all that. That guy's really well known. I'm playing tennis with him. I'm playing basketball at the Embassy on the weekend. I'm like, "What the hell? I'm 24 years old. This is amazing." 
xxxix Exemplar (Israel): Again, it's a "not much oversight" job because my bosses are really in the U.S. I'm obviously subject to the leadership of the senior U.S. military folks here in Israel. If the one star general in charge of our military team here in Israel says, says I should or shouldn't do something, I'm going to do it or not do it. But my chain of reporting and evaluation. . is in the U.S. In other words, I have this base set of objectives I'm supposed to do, and at the end of the year, someone might look and say, "Did you do them or not? No one is looking over my shoulder every afternoon to see what I'm doing. I could do very little for months if I wanted, and it would only slowly be noticed. It is a very self-driven job.

Exemplar (Afghanistan): But hell, it was a lot of fun. [Name of district liaison], he had been there for the other team and we had replaced them. He told us, I think two or three months into our rotation, "You know, you guys are the reason why I decided to stay here and extend and close this place out." Because when we showed up, we're working until 10:00, 11:00 every single night for the first month and a half to two months that we were there just trying to get everything straight. And we're hungry. We all wanted to do great shit. We saw, "Hey, these were things that needed to get fixed," and we just worked on it. Some of it was things for the Afghans, but how we organized our reports, how we did our reports, working through that, conducting some missions and getting our feet wet and then trying to see, "Hey, where we're at now, did we think that's where we were going to be at 60 or 90 days in?" Trying to reevaluate where we were at.

${ }^{\mathrm{xl}}$ Exemplar (Mexico): That's just an example, but it's like that everywhere. And in every country, you have the little things that you have to live. The people at the company [in the host nation], they know this is normal life. It has a reason. . maybe corruption, maybe idiosyncrasy, maybe history. When you bring it to the U.S., it's difficult for people that are never being exposed to that, to understand it and then accept it. . . It's my job to keep things moving, and keep things moving in the right direction, and keep things improving. It's my job to become the translator. It's my job to become. . you remember that bridge, I told you about between the two different cultures? It's my job to make sure traffic happens in a way that is accepted in both sides. Right? So I go to the U.S. and I tell them, this is the law. This is what happened. This is the reason why the law took place. And these are the consequences if we just ignore that situation. And I become the cheerleader on what's happening in what I'm working. A cheerleader for the team, cheerleader for harder working. So people here, home office, all of a sudden, it doesn't become a foreign place or something that happened thousands of miles away. It's something that will impact us here, if we don't act in an effective way. The same thing happened on the other side. I mean, whatever happens in home office, and there's very good reasons, I need to translate on the other side. So they don't see it as anything negative but, "Hey, this is positive. And everybody gains if we move in this direction." So, my job is to make sure that communication happens in a way that nothing important is lost in translation. So we can move parallel in the same direction. And that can be challenging sometimes. Sometimes it takes time, but the more you do it, the more you get to learn the key players and how to talk to them.

xli Exemplar (Afghanistan): [One lesson] I always try to impress upon our especially younger SOF operators. . . they may want to be more Western and more developed, but they're not trying to get there overnight. So let's not push something that's an American solution on an Afghan problem, but let's look at what their problem set is.

Sometimes just a different level of leadership would have taxes, and some people would call that corruption. Others would say, "Sure, it's an unofficial tax, but they also pay for the family 
members of government officials who are injured or killed, or things that the national government isn't paying for, isn't reimbursing them for."

They don't want an American solution. They can't sustain an American solution. Quit trying to give them air conditioners for every office they have. They have no power. Right? You can pave a road, but if the road goes to nowhere they're going to drive to, why are we paving that road? Right? Let's focus on the things that work.

Just learning the different dynamics of how things go there and then doing what you can to help. I mean, it really played well into those other jobs where I may have only been there for one month, two months, a couple of weeks or whatever, but the same type of thing, whether it's Africa, or a different part of the Middle East, or a different country, it's the same type of thing. "What do the people need and want?". Listen to them, so you can actually hear what they want, not immediately give them a solution to a problem they may not even have.

Exemplar (Afghanistan): [Regarding lessons learned during the assignment] The importance of learning people's history, why they are acting that way, tribal feuds. When we were at the director of police intelligence on the next one, why were all these generals hating each other? Well, it's because, I found out, they were part of rival communist groups inside of the former Afghan government. They were part of the different ones, Khalq and Parcham, and one was a Maoist. And you're like, well, I mean, they were all generals with the same group, but they were part of rival factions, and they probably tried to murder each other 15, or 20 years ago.

I did, basically, an oral history of the Ghorak District, just. . . asking them, "Hey, so tell me what it was like here." I was able to diagram out, "These are the tribal feuds. These are why they're not going to get along with it. This is why we have to give them a little bit more than we're giving these other people." I think what I learned is that if you want to understand why they're acting this way, or why they don't get along, or why there's tension here, you have to dig deep and get beyond their talking points.

Exemplar (Mexico/India/Costa Rica): I also learned, my staff in India for example, they didn't like to say no. And they didn't like to say that they didn't know. So, when I asked them to do something they will say, "Yes, we'll do it." And then I realized they have a process. They pay them in Costa Rica in U.S. dollars as opposed to colones, which is a currency in Costa Rica. The currency in Costa Rica at the time was 550 colones per dollar. So, all of a sudden, my payroll for one of my offices has increased by a hundred percent! It's like, "What in the world happened?" And it's because they didn't tell me that they didn't know. It's just part of the culture. And. . we were able to catch it and we didn't disburse it, but it could have been a very big disbursement, had I not cut it. And we could have prevented just by learning those little things. And again, once you learn it, it's easier for you to not only embrace it, but integrate yourself and become part of the team and also become more effective.

xlii Exemplar (Germany): I took a risk, but it paid off. . . But it was like I said, understanding that you have to have that level of granularity about how a place works to be effective I think really started even way back then. If something even kind of looked off, you've got to be willing to dig in, do a little bit of homework and maybe take a little risk, but definitely do your dig first. The first step is always information collection. ... And then you can probably be effective, impactful. You can figure out a solution, whatever that might have to look like. And it may not be something that looks like what we're accustomed to in the U.S.

xliii Exemplar (Korea): I had been there for a couple years when, I forget what the occasion was, but one of the counterparts on the Korean staff walked through with me the OPLAN that we kept 
so closely guarded because it was classified. It was RELROK. It was releasable to the Republic of Korea and their armed forces. So you had all these protocols in place to safeguard US secret and ROK secret. The OPLAN that we were working on, by statute in the Korean government, it sits in their congress so that any member of their congress has access to it.

Their elected officials include members of the Korean Communist Party. So the entire OPLAN that we were. . . Everything's so closely safeguarded. In actuality, I'm pretty sure they got a copy north of the border that they go to on a pretty regular basis. It was the recognition that so much of what I was doing was in order to look like we were doing that rather than. . really for its intended purpose. . . No, it's mostly just so that you can be seen doing that. That's what important about it. It's important that you do it, but it's only important to the extent that it's part of the communications; it's part of messaging. That took a long time to get through my brain.

${ }^{\text {xliv }}$ Exemplar (Italy): The school arranged to either buy or rent these apartments. And. . . all of the other floors on the building were also my classmates who were from, you know, half of them were Americans and then half of them were various types of Europeans. So not just Italians, like Scottish and Israeli. They just, lots of different, Azerbaijani and French and Dutch and Austrian. ... The thing that was profound about it was that we. . when we all got there, we didn't really like each other that much. And because we didn't choose each other as friends. And you had like your little clique of friends. .. . Like, you had that group, but by the end of the year because there were only about, I think there were only about 120 of us, you had to find something that you liked about everyone, because it was like you were all on this boat, on the ocean of Italy. . . because. . . the Italian culture was so hard to penetrate other than the people that were in your class. ... Y You had to figure out how to like these people, even though you were not predisposed to like them. And as a result, we are all the best of friends. It's like having siblings in a way, like you don't pick your siblings. That just happens. ... I think that's the best part.

Exemplar (Tajikistan): I'll say I probably had one of the strongest expatriate communities aside from my time in Hanoi that I experienced. Because it is in the foreign nowhere, the expatriate community is very strong in Tajikistan so it was probably my most positive experience. It's very much like university or college. If you have a great group of people you're there with it can be a great time, even if it's a terrible school. If you have a terrible group of people there and you have no friends and you're just miserable, no matter how great the school is and no matter how great the environment is you can just have a terrible time. Tajikistan had a great group of people. Really tight knit group of folks.

Exemplar (Mali): That environment was probably the most diverse I ever worked in because you're not just dealing with the local population to gain atmospherics. You're also working with a staff that was from various nations within the UN. And I worked, probably mainly, I mean I worked with the high staff. The Chief of Staff was. . German. My counterpart, the French G5 [Chief of Plans], he was French. . . And we had some Egyptian officers working in the shop. And then working for me I had about, I don't know, probably about eight different nations worked for me. And I had 12 officers under me. A German, a Frenchman were my principle G35 [operations planning] staff. Then obviously we had a few Americans. But then dealing with other, let's say African nations such as Burkina Faso, Togo, Chad, also Pakistan, which was quite interesting. We had. . . a Pakistani Intelligence Officer. Actually,, my G2 [Chief of Intelligence] was from Burkina Faso. So, I worked hand in hand with him as well. . . So it was quite a diverse experience and probably the most challenging one I've had. 
${ }^{x l v}$ Exemplar (Afghanistan): When you get tired, you shortcut your communications to what you feel more comfortable with. I also learned to be well rested when I have to do cross-cultural interactions, because if I'm not well rested, I will take a shortcut, and that shortcut does not behoove anybody. Also, I find that if I am tired, I am more biased, based on my previous experiences, particularly if the previous experience has been bad. And, I miss cues. So, I have to make a concerted effort to be well rested, to be as patient as I possibly can. . .

Exemplar (Mauritania): I think you can internalize, "I should do this," or "I should do that," but it's hard to then layer that with, "I'm away, I'm hot, I'm tired, I'm angry and I'm hungry and I'm all these things too, but I still have to act this way, and there's no one there to oversee me whatsoever except myself."

And honestly, there were a few days where I just said, "Hey, I'm not doing anything today. I'm not going to go in because there's nothing good that's going to come." Obviously in that environment, I had the flexibility to make that call and that was fine. And then I think layered on that is then work pressures. So, maybe D.C.. . . they have a view of how something should go. . . . And so they're just trying to shove that down 4,000 miles away. ... And so there's a lot of those pressures as you know that have a huge impact too. And you're frustrated with that or like, "Hey, no, I didn't do really anything this week, but I did a lot by doing nothing." And I think that's the other cultural thing. I wasn't in the capacity of being able to just hang out and live with the tribe and understand them. It's also a job. And I saw that with others too, regardless of whether they wear a uniform or not.

${ }^{x 1 v i}$ Exemplar (Afghanistan): I thought it was going to be really difficult. I thought it was going to be something that was very challenging, and it was, but it was the best deployment I ever had. ... It might have been 2012, but it was really 2001 because there was nothing there, nothing. The district center had been burned to the ground by the Taliban, so that we were, basically, starting from scratch, which was really difficult and an impossible assignment, but really hard. And it was ... I learned a lot.

... I've never been what I would call an incredibly optimistic person, but I think that assignment really gave me a harder edge. I was very angry at the way that it was conducted, and there was some other stuff that happened that I wasn't happy about. So I think, for a long time, it made me very bitter. But it also changed me. This is what I love to do. I don't like the military bureaucracy. I hate it. I hate the paperwork. I hate it. But I love being deployed. I love being over there. I love being immersed in another culture and trying to figure it out because it's the hardest thing in the world. It's challenging like nothing else is. That definitely changed me for the better. Exemplar (Germany): I would say it was better in that it was more challenging. It afforded me more opportunities for those challenges. I know that those things go together than what I had really expected, I think I had expected Germany to be even more like the U.S. I didn't account for the full range of distinctions in the law, the legal system, whether it was with the forest meister or other similar topics. Likewise, I didn't fully appreciate the extent to which going from a relatively, in comparison, small installation with relatively few number of flights, two major airframes at Ellsworth to Ramstein having everything under the sun for practical purposes to include coalition airframes.

Exemplar (Afghanistan): To me, that was a success when we built the relationships to where you can almost read the governor. We had a couple of crises in our province and being able to reach out to the governor and know that he'll reach out or he'll respond to you and give you a real update, not be a politician with you - getting our governor to earn our trust enough where we were able to take him out of the relatively secure city center and into the districts, which he had 
not done in the two years previous during his time as governor. I felt that was a huge victory for us just to get him out to some of the villages and meet the people. You have those small little victories and they really go a long way as far as you realizing you're doing what you're supposed to be doing, but also reinforcing that style of engagement.

... I really enjoyed it. I can still say to this day that I would go back and do that job continuously. I think it's very rewarding because you get to learn about the country you're in from a personal level, not just, "Hey, I'm going to fight people." And then you blanket everybody across that country as anti-American or anti-your way of thinking. I think the challenges, while painful and frustrating at times, were definitely worth it. When you came to those small little victories, that much more rewarding because you've adjusted or you've helped your team adjust to what you're trying to really accomplish. It was a great assignment, honestly.

Exemplar (Mali): [On volunteering to be a UN peacekeeper] I was interested because it was a challenging cross cultural experience. And that's why I hit on it.

Exemplar (Afghanistan): I learned how to manipulate situations in positive ways. I learned how to get to the end result in a way where everybody thought that they won which I think is a fantastic irreplaceable skill. I learned how to blend in - but maybe I didn't. I think that I learned how to blend in some, but I probably did not blend in at all. That one might be in my head. I certainly learned how to adapt. .. .

But I think it solidified who really my closest friends and community are and it's folks who continue to care about other countries and other communities and in different ways, try and make a difference and be impactful. It's folks who try to be understanding of perspectives beyond their own. So, people aren't really as good at that as they think they are. And I think it's certainly the resiliency aspect that we talked about that makes all kinds of things I think a lot less challenging, including a global pandemic where you're locked inside your house. . . just really isn't that big of a deal is what I've kind of found in talking with others. 


\section{APPENDIX 2:}

\section{METHODS OF ASSESSING INTERCULTURAL COMPETENCE FOR INTERNATIONAL ASSIGNMENTS: A REVIEW}

\section{Tagline}

The rewards of sending personnel on overseas assignment can be high, but so can the risks. How can organizations cost effectively assess and select the right person?

\section{Keywords}

Intercultural Competence

Cultural Intelligence

Intercultural Adaptability

International Assignments

Business Expatriates

Meta-review

Assessment

Instrument

Selection

\section{Executive Summary}

Despite the high cost and high frequency of failure in expatriate assignments, the potential value and opportunity gained by sending employees overseas is driving the number of business expatriates skyward. One way organizations can significantly mitigate risk is by assessing and selecting candidates for intercultural competence. Intercultural competence has affective, 
cognitive, and conative aspects. It can be measured via inventory or survey instruments, works of creative self-expression, dialogue, case study or critical incident analysis, and performance in real or contrived situations, but each approach has strengths and weaknesses. Experts recommend multiple assessments via mixed methods. Survey instruments have become prevalent in business because they are simple, quick, inexpensive, and yield easily comparable results. The author of this article conducts a review of reviews, or meta-review, of available survey instruments. Out of several dozen surveys, five met the criteria for review in this article, and three proved more valid and reliable than their peers. The author closes by discussing the services of global mobility consultants with proprietary assessment and training methods, then making recommendations for candidate selection processes based on risk tolerance, resources available, and the magnitude of the requirement.

\section{The Research Problem}

Successful expatriate managers create value and opportunity, transfer knowledge, enhance communication, and enable better control (Collings, Scullion, \& Morley, 2007, p.6; Feitosa, Kreutzer, Kramperth, Kramer, Salas, 2014, p.4). So although expatriation is the costliest staffing option for multinationals (Selmer, 2001), international assignments will continue to multiply. About $63 \%$ of companies saw their number of expatriate employees stay the same or increase between 2014 and 2015, and 75\% expected that number to stay the same or increase through 2017 (Brookfield, 2016, p.48). Many firms now require international experience for advancement to senior management (Mesmer-Magnus \& Viswesvaran, 2008, pp.189-190).

Expatriate failure is common and costly. Sixteen to forty percent of expatriate assignments fail to accomplish company goals, often due to ineffective adjustment and relationship-building. Overall, about $20 \%$ return home early, but from developing nations, the estimate is $70 \%$ (Graf \& 
Harland, 2005). Estimated costs for a typical failure (lost business, preparation expenses, etc.) run between $\$ 250,000$ and $\$ 1.25$ million. Such a failure can also devastate the career and selfesteem of a once-promising assignee (Mesmer-Magnus \& Viswesvaran, 2008).

Research commonly cites lack of intercultural competence as a primary reason for expatriate failure (Bird, Mendenhall, Stevens, Oddou, 2010; Gertsen, 1990; Johnson, Lenartowicz, Apud, 2006; Josien, 2012; Kraimer, Bolino, \& Mead, 2016; Peltokorpi \& Froese, 2012). However, despite a body of research recommending formal assessments of intercultural competence for expatriate assignees, businesses frequently ignore intercultural competence and focus overwhelmingly on technical competence (Graf \& Harland, 2005; Kraimer, Bolino, \& Mead, 2016; Mesmer-Magnus \& Viswesvaran, 2008; Peltokorpi \& Froese, 2012).

This article will outline the different approaches to intercultural competence assessments and describe the strengths and weaknesses of each. It will then provide a meta-review of the most common assessment instruments prevalent in the literature and make recommendations on the assessment methods most suitable for use in practice.

\section{Spectrum of Approaches}

As a construct, intercultural competence can be defined as "the ability to grasp different cultures, interact appropriately within them, and work effectively." Alternate terms for similar or equivalent constructs include cross-cultural competence, cultural agility, intercultural adaptability, and cultural intelligence, among others (Fantini, 2009, p.457; Deardorff, 2011, p.65). The most widely cited frameworks for intercultural competence demarcate three to five dimensions. The motivational or affective dimension involves values, motivations, and interests. The motivational or affective dimension involves values, motivations, and interests. It provides the will and capacity to develop and employ intercultural competence. The cognitive dimension 
is the one most often broken out into additional dimensions, as it involves culture-specific knowledge, culture-general knowledge, and metacognition - how one learns, thinks about, and interprets cultural knowledge and behavior. The conative or behavioral dimension encompasses skill and behavior - how one speaks and acts (Hennings, 2018).

With selecting any method of assessment, it is important to determine its goal (Fantini, 2009, pp. 460-461; Deardorff, 2011, p.73). In this case, a suitable answer may be "identifying candidates suitable for preparation and deployment as assigned expatriates." That provokes further questions regarding the nature of both the preparation and the assignment. Is it possible to tailor pre-deployment training to the needs of the assignee? Such a circumstance would increase the value of rigorous, thorough assessment and detailed feedback (Mesmer-Magnus \& Viswesvaran, 2008, p.188; Feitosa, et al, 2014, p.142).

Knowledge of the assignment is essential to the next steps in evaluating a method of assessment - examining the framework or model upon which it is based, and then determining whether it is designed to achieve the specific objective (Fantini, 2009, p. 460, 465; Deardorff, 2011, p.68). Unless explicitly stated, this article will discuss only assessment methods based on frameworks similar to the one stated in the previous paragraph. Even within that set, however, some methods focus on some aspects of intercultural competence more than others.

Regarding the assignment, intercultural competence in general is desirable, but may be less important when the sending and receiving cultures are similar (e.g., Canada and the United Kingdom). Similarly, some aspects of intercultural competence may be more important than others for a particular assignment. Those distinctions should be identified early on and taken into consideration when selecting methods of assessment (Fantini, 2009, p.465). For example, an American assigned to live and work in Japan must be able to adapt to a high power distance, 
high context culture, where rank is extremely significant and communication is indirect. If available, the experiences of previous assignees in similar locations and positions can be a useful guide for what is required (Fantini, 2006).

Decades of studies of intercultural competence have generated a surfeit of approaches for evaluating it (Yu, 2012, p.169; Fantini, 2009, p.464; Deardorff \& Deardorff, 2007, p.93; Deardorff, 2009, p. 482; Cantele, Groeschke, Sandu, Barrett, 2015, p.24; Griffith, Wolfeld, Armon, Rios, \& Liu, 2016, 7-15). This review will assess the applicability of those approaches to the selection of expatriate assignees. However, it is important to note that intercultural competence should not be the only factor in selection. This review has already lamented the emphasis on technical and professional competence at the expense of other considerations. Nevertheless, those qualities are admittedly critical (Mesmer-Magnus \& Viswesvaran, 2008, p.187; Feitosa, et al, 2014, p.140). Other weighty dynamics include (but are not limited to) the following:

- cultural distance, or the degree of difference between the cultures of the assignee and the receiving hosts (Nelson, 2019; Linville, 2012; Mesmer-Magnus \& Viswesvaran, 2008, pp.188-189, 194)

- individual cultural orientation - personality traits that make a person more adaptable to some cultures than others (Linville, 2012; Mesmer-Magnus \& Viswesvaran, 2008, pp.184-185)

- the intercultural competence and cultural orientation of the assignee's family members (Mesmer-Magnus \& Viswesvaran, 2008, pp.187-189, 193-194; Feitosa, et al, 2014, pp.137, 147; Nelson, 2019) 
- the practical global mobility considerations of the entire family - i.e., their physical, mental, and emotional readiness to live and work in the target environment (Magnus \& Viswesvaran, 2008, p.189; McNulty, De Cieri, Hutchings, 2013)

- (closely related to the above bullet) state fragility - i.e., the degree to which security, rule of law, economic opportunity, and basic services are in question (Nelson, 2019)

The practical considerations in the penultimate bullet above include everything from crime rates to requisite medical care to job opportunities to schooling. Organizations must consider these issues on a case-by-case basis, because they vary in each location and for each family.

The leading lights in the study of intercultural competence recommend assessing a mix of quantitative and qualitative data (Deardorff, 2006, p.241). The most prevalent approaches are to assess the following (Yu, 2012, p.169; Fantini, 2009, p.464; Deardorff \& Deardorff, 2007, p.93; Deardorff, 2009, p. 482; Cantele, et al, 2015, p.24):

a) self-reporting through inventory or survey instruments

b) works of creative self-expression

c) dialogue

d) case study or critical incident analysis

e) performance in real or contrived situations

Inventory/survey instruments are the most common quantitative approach. The next four are generally qualitative. However, there is variation. Within each category, as the structure of data collection increases and the latitude of responses decreases, the methods increasingly behave as quantitative instruments. The corresponding advantages and disadvantages of each extreme (covered below under Works of Creative Self-Expression) arise accordingly. Instructors 
frequently use methods on the more qualitative end of the spectrum to help develop intercultural competence as well as assess it.

In recent years, researchers have identified less intuitive, but potentially no less valid measures and indicators, such as social network analysis (Chi \& Suthers, 2015). This article will focus on strategies currently considered conventional, i.e., those for which there is a deeper history of study and use. However, the utility of this review is finite in time, because research is continually moving forward.

\section{Self-Reporting Through Inventory or Survey Instruments}

These instruments typically consist of statements or questions with Likert scale or, less often, multiple choice responses. They are the most common method of assessing intercultural competence discussed in the literature, and they are in wide use (Yu. 2012, p. 176; Griffith, et al, 2016, p. 31) for multiple reasons. They are quick, easy to use (Deardorff \& Deardorff, 2007, p.91; Dervin, 2010, p.8) and often inexpensive, although some require trained proctoring and scoring (Paige, 2004, p.91). They are also uniform across every assessment, which facilitates performance comparisons (Griffith, et al, 2016, p. 12) and testing for validity and reliability. There are a great variety (Fantini, 2009, p.465), so if a particular aspect of intercultural competence is desired, one can choose an instrument focused on assessing that component.

However, survey instruments have limitations. Some researchers have proposed that the near-ubiquitous Likert scale responses (often ranging from "strongly agree" to "strongly disagree") can effectively measure the motivational dimension, but multiple choice or forced responses (e.g., "Select the statement that best describes you") are more effective at measuring the cognitive and conative dimensions (Griffith, et al, p. 12). Surveys also suffer from the cognitive bias problems inherent to all self-reporting-especially social desirability bias. Social 
desirability bias is the tendency to give the answer that the respondent believes is viewed most favorably. At its most extreme, social desirability bias can lead subjects to deliberately falsify responses. Inexperience can also degrade validity, as a person may be asked to describe his usual response to a situation he has never experienced. These weaknesses can create a gap between what a person reports about her ideas, attitudes, and actions and how the person will actually think, feel, and behave in a cross-cultural situation (Yu, 2012, p. 178; Griffith, et al, 2016, p. 23; Dervin, 2010, p.23).

\section{Works of Creative Self-Expression}

This category includes a wide variety of written works, especially critical reflections of cross-cultural experiences, journal entries, blogs, papers on cultural topics, and autoethnographies. However, they can also include photo essays and video and audio recordings. Academic settings use these extensively, because they require creative work to measure student learning and they are staffed to receive it and evaluate it. These artifacts - along with the products of other approaches on this list, such as inventories, critical incident reflections, and performance evaluations - can be gathered into portfolios and assessed collectively, as well as individually (Yu, 2012, p. 175-176; Griffith, et al, 2016, p. 23; Deardorff, 2009; Deardorff, 2011; Fantini, 2009; Cantele, et al, 2015, p.24).

Individual artifacts and portfolios of creative self-expression are the opposite in every respect from inventory instruments. Works of self-expression are exceptionally flexible and can be tailored to the assessors' priorities. They provide context and depth and are consequently difficult to fake. Because portfolios can include multiple measurement approaches (e.g., autoethnographies, surveys, or critical incident analyses), they facilitate triangulation. This can 
significantly increase the confidence level of an assessment (Sutton, Miller, \& Rubin, 2007, p.33)

However, portfolios require a qualified evaluator and a rubric ${ }^{1}$ to measure them by, and there is a considerable time cost for both the subject and the evaluator. And as each artifact or portfolio is unique, any comparison across individuals is debatable (Fantini, 2009, 464; Yu, 2012, p.175-176; Griffith, et al, 2016, pp.7-8). Finally, the nature of such work may "tell us more about students' language, analytical, and overall academic skills than about their intercultural competence" (Yu, 2012, p.173; Dervin, 2010, p.9)2. These strengths and weaknesses do not preclude the assessment of works of creative self-expression in practice; however, in many cases, they will make this approach more suitable to the academy than practice.

\section{Dialogue}

"Dialogue" in this case includes interviews, focus groups, debate, and any discussion-based assessment (Fantini, 2009, p.464) . One or more of these qualitative methods are often used in conjunction with more quantitative self-assessment instruments (Cartwright, 2016, pp.7,12; Fantini Appendix F, 2006, pp.89, 91; Deardorff, 2006, p.241). Even by themselves, dialoguebased assessments are a rich source of data. Students are both less inclined and less able to adjust their responses for social desirability, and interviewers can assess both nonverbal and verbal responses. The less structure, the more telling (and often more unexpected) data will result, but the more difficult the results are to assess reliably (Yu, 2012, p.180). The conduct and interpretation of these assessments generally requires a trained professional. That person

\footnotetext{
${ }^{1}$ Rubrics are available through the American Association of Colleges and Universities (AACU, http://www.aacu.org/value/rubrics/) (Deardorff, 2011, p. 73)

${ }^{2}$ One could argue that this is not a weakness, since in most assignments abroad, the academic skills of organizing work and communicating clearly are directly related to success.
} 
represents an expense, whether he or she is part of the organization or an external service provider. Given the far higher cost of expatriate failure, the expense may be a prudent one.

\section{Case Study or Critical Incident Analysis}

In these assessments, the subject receives a scenario involving intercultural interaction and responds with his or her analysis - how culture is a factor, what is being done right or wrong, and what the most effective next steps would be. These scenarios provide context, and that context is the basis for all their strengths. It enables the assessment to get one step closer to reality than in an inventory or interview, with a potential corresponding increase in validity. Unlike many of the works of creative self-expression, this approach isolates intercultural competence somewhat from academic skills. There are a number of intercultural cases available in textbooks and collections (Yu, 2012, pp.173-174), and it is possible to adjust them to the needs of the assessor. The weakness is the same as that of dialogue-based assessment: the need for a qualified facilitator/assessor.3

\section{Performance in Real or Contrived Situations}

The value of observing real performance is obvious, as "It is axiomatic in personnel selection that past behavior is the best predictor of future behavior" (Mesmer-Magnus \& Viswesvaran, 2008, p.185). This approach provides past behavior to assess. However, depending on circumstances, real intercultural interactions may be hard to come by before the expatriate is abroad. Role play, and to an even greater degree, computer-based simulations, reduce the realism of this potentially highly valid type of assessment. Furthermore, they can be labor, cost, and time-intensive to generate (Yu, 2012, p.181-182). Nevertheless, they are in use in

\footnotetext{
${ }^{3}$ Situation-judgment tests provide an abbreviated case description and request responses to specific questions, often selections from a multiple-choice list. They represent the most structured and therefore easiest to assess form of both critical incident analysis and performance in a contrived situation. However, there are validity issues (Griffith, et al, pp.13-14)
} 
organizations where the requirements justify the expense, as in some military occupations (Griffith, et al, 2016, pp.14-15).

Two potentially telling methods of performance observation are the 360 degree assessment and the host family assessment. In 360 degree assessments, people who interact with the subject (supervisors, peers, and subordinates, for example) rate the subject on constituent attributes or skills of intercultural competence (Cartwright, 2016; Fantini, Appendix F, 2006). Host family assessments are similar, but specifically for use when a subject spends time abroad in a host family's home. For the purposes this review is designed to support, the expatriate selection may already have been made at that point.

The 360 degree and host family approaches are often an adaptation of self-report instruments and can be similarly quantitative. However, they eliminate self-reporting issues. Their most obvious potential weaknesses derive from the observers themselves. Their observation skills and the quality and quantity of their observations can vary widely; that variation can affect the validity and reliability of the assessment (Dervin, 2010, p.9). Even so, the observers have observed the subject's real-life behavior, unbiased by any knowledge of an assessment taking place, and their insight can be revealing.

\section{Meta-Review of Assessment Instruments}

This section will integrate other researchers' reviews of the most prevalent methods of assessment, which are instruments. The criteria will be validity, reliability, and cost in time, money and labor. To meet the standard for inclusion, each instrument had to meet three criteria. First, it had to have been compared against an array of others in at least three peer-reviewed articles. 
Second, it had to assess a construct that is both of sufficient scope and roughly similar to the aforementioned framework for intercultural competence. In other words, the measured construct must include cognitive, motivational, and conative dimensions, with multiple components for each dimension. The lone exception to this rule is the Intercultural Development Inventory (IDI). Its wide usage, especially in selection for international assignments, necessitated its inclusion. The IDI derives from the Development Model of Intercultural Sensitivity, or DMIS, a construct which is unique in that it focuses on stages of development (Stuart, 2008, p.182; Paige, 2004, p.99; Wang \& Kulich, 2015, p.39). However, to identify the subject's DMIS stage, the IDI measures knowledge, skills, behavior, and other personal factors (KSAOs) just like other instruments in this review (Bücker and Poutsma, 2010, p.273).

Third, the instruments must have the support of a generally successful body of validity and reliability testing. "Validity indicates whether the test measures what it says it does and relates directly to the test's purpose. Reliability tells how well the instrument produces consistent results each time it is used. Tests with high validity and reliability factors are obviously desirable" (Fantini, 2009, p.475).

Validity, however, has multiple aspects. Content validity is often the type of validity researchers check for initially. It is the extent to which the items in the test appear to represent what the test is supposed to measure. This means how it appears to subject matter experts, not how it appears to laymen, which is face validity. Content validity is somewhat subjective because it depends upon general agreement regarding the meaning of the trait being measured (Pennington, 2018, p.37; Sercu, 2004, p.79). In 2013, Matsumoto and Hwang determined that evaluations of content validity for instruments measuring intercultural competence should seek to answer the following questions (p.851): 
1. Were the desirable outcomes clearly identified and defined?

2. Were the target cultures clearly identified?

3. Were the knowledge, skills, abilities, and other characteristics (KSAOs) associated with the desirable outcomes in the target cultures clearly defined?

4. Did the KSAOs exhaust the possibilities of all KSAOs that could potentially be predictive of the desirable outcomes?

5. Did the generated item pools exhaust the possible universe of measurement for each KSAO?

Construct validity is narrower than content validity. It is the degree to which the test measures the construct it is supposed to measure (Sercu, 2004, p.79). Construct validity has multiple components, including structural validity, convergent validity, divergent validity (Lieberman \& Garnst, 2015, p.18). Structural validity is "the extent to which items designed to measure a particular factor (i.e., latent construct) actually do so" (Byrne, 2000, p.99) or the extent to which the scores of an instrument adequately reflect "the dimensionality of the construct to be measured" (Mokkink, et al., 2010, p.743). For our purposes, structural validity describes how well the instrument measures all the dimensions of the intercultural competence construct it is designed to measure. Convergent validity shows that the instrument is measuring what it is supposed to measure by demonstrating correlations with measures of related constructs. Divergent validity is also known as discriminant validity. It shows that the instrument is not also measuring something else by demonstrating modest correlations with concepts distinct from intercultural competence (Lieberman \& Garnst, 2015, p.18; Matsumoto \& Hwang, 2013, p.851). 
Ecological validity is essentially correlation with real world outcomes (Lieberman \& Garnst, 2015, p.18; Matsumoto \& Hwang, 2013, pp.851-852). Its two most important subcomponents for the purposes this article supports (selection and preparation of assigned expatriates) are concurrent and predictive validity. Concurrent validity occurs when that correlation is established at the same time as the assessment (e.g., someone with demonstrated cross-cultural interaction success doing well on the corresponding portions of the assessment). Predictive validity for this field is the ability to reliably predict performance in intercultural settings (Bücker \& Poutsma, 2010, p.277; Sercu, 2004, p.79). Unfortunately, thoroughly testing the predictive validity of intercultural competence requires consistent performance measurement criteria and ideally a longitudinal study (Griffith, et al, 2016, p.26). Thus, predictive validity has been tested less often than other aspects.

Reliability also has multiple aspects. Two that are most relevant to this article are internal reliability (or internal consistency) measured by Cronbach's Alpha, and test-retest reliability. Internal reliability means, for our purposes, that items on a survey instrument intended to measure the same aspect of intercultural competence receive similar responses. Test-retest reliability is what Fantini addressed above - consistent results across multiple uses of an instrument on a specific subject, assuming all else remains the same. For example, if a subject takes a course in cross-cultural communications or spends a semester abroad between two survey iterations, one could expect results to differ. A third category, parallel forms reliability, measures correlation between two different (but ostensibly equivalent) versions of an instrument. It is particularly relevant to this topic when different versions of an instrument are prepared for different languages and cultures. 


\section{Cross-Cultural Adaptability Inventory (CCAI)}

The first instrument under review is the CCAI, which Colleen Kelley and Judith Meyers developed in 1987. It is a 50-item survey using a five-point Likert scale to assess four components of cross-cultural adaptability - Emotional Resilience, Flexibility/Openness, Perceptual Acuity, and Personal Autonomy. It can be used in either self-report mode or with three selected observers as a $360^{\circ}$ feedback instrument (Stuart, 2008, p.178; Cartwright, 2016, p.33; Perry \& Southwell, 2011, pp.461-462; Matsumoto \& Hwang, 2013, p.854; Paige, 2004, p.114; Griffith, et al., 2016, p. 8; Bücker and Poutsma, 2010, p.283)

Kelley and Meyers designed the CCAI specifically to measure a person's ability to adapt to other cultures. It is in wide use in both academic and workplace environments for data-based training, program evaluation (pre- and post-testing), and consultation. Kelley, Meyers, and other trainers who use the CCAI claim that it helps learners understand and develop the components of intercultural competence. To facilitate that use, there is a follow-up training tool called the CCAI Action Planning Guide and other supporting material. Most relevant to this review, users recommend the CCAI as a self-selection instrument for international assignments - i.e., helping a candidate determine whether she or he wants to work abroad - or as part of a battery of testing for selection (Stuart, 2008, p.178; Cartwright, 2016, pp.33-34; Perry \& Southwell, 2011, pp.461462; Paige, 2004, pp.114-115).

The CCAI's early development, simplicity and low cost have all contributed to its extensive use. Administrators need no certification (Stuart, 2008, p.178). The inventory itself takes twenty minutes to complete. For a little over $\$ 300$, one can purchase everything required to assess and provide feedback to five people, as well as conduct a four to eight-hour seminar. The seminar is intended to help participants "explore their own cultural identity and learn to improve 
their interactions with other cultures" (http://ccaiassess.com/product_pricing.html, https://hrdqstore.com/products/cross-cultural-adaptability).

Kelley and Meyers based the instrument on the literature available in 1987, submitted the items to a panel of expert judges, and used factor analysis (Paige, 2004, pp.114-115). On the four subscales, reliability (internal consistency) coefficients range from as high as .82 to as low as .68 - slightly below the usual .70 cutoff for acceptability. An unreliable subscale assessment can degrade the utility for tailored feedback and training plan development. The overall scale rates an impressive 90 . Two studies found poor evidence for the four-factor structure, and one of those specifically found poor divergent validity between the subscales. They correlated highly with each other, suggesting that they are all measuring a unitary dimension of intercultural adaptability (Paige, 2004, pp.114-115; Griffith, et al., 2016, pp. 15-16, 21-23; Stuart, 2008, p.178; Perry \& Southwell, 2011, p.462; Matsumoto \& Hwang, 2013, p.854).

Research shows some evidence of convergence between the CCAI and the Big Five personality traits of extroversion, agreeableness, conscientiousness, emotional stability, and openness to new experiences (Griffith, et al., 2016, pp. 16, 21). One study found significantly higher scores on the CCAI among graduate students who had received intercultural competence training compared to those who had not, suggesting potential predictive validity (Matsumoto \& Hwang, 2013, p.854).

\section{Multicultural Personality Questionnaire (MPQ)}

Dutch researchers Karen I. Van der Zee and Jan Pieter Van Oudenhoven developed the selfreport MPQ in 1998 and revised it two years later. The number of items vary in different versions - originally 78 , then 91 , and most recently 40 . All use a five-point Likert scale. Of the five traits the MPQ measures, three - cultural empathy, open-mindedness, and social initiative - 
have demonstrated the potential for improvement after training or other relevant life experience. The other two, emotional stability and flexibility, are more stable. The MPQ is designed primarily for self-assessment, but may be used to assess risk in international assignment selection, as it may predict how well a person will adjust to another culture (Stuart, 2008, pp. 180-181; Bücker and Poutsma, 2010, pp.274, 288; Matsumoto \& Hwang, 2013, pp.861-862; Griffith, et al, 2016, p.9; Van der Zee, Van Oudenhoven, Ponterotto, \& Fietzer, 2013, p.121; Mello, 2014, p.376; Tamas Consultants. n.d.).

The MPQ is well-validated. It has demonstrated internal reliability at both subscale and scale level as well as construct, content, concurrent, and predictive validity, even across widely varying cultures. In fact, its validity in predicting adjustment and adaptation exceeds demographic variables, personality measures, standard intelligence measures, and the Cultural Intelligence Scale (CQS) described below (Bücker and Poutsma, 2010, pp.274, 288; Matsumoto \& Hwang, 2013, p.861-868; Griffith, et al, 2016, p.18). It costs $€ 60$ (H. van der Heijden, personal communication, 6 August 2019), takes ten to fifteen minutes to complete online, and immediately generates a report describing the meaning of each subscale score. Consultants may offer more detailed feedback (Tamas Consultants. n.d.; KIT Royal Tropical Institute, n.d.;).

\section{Intercultural Adjustment Potential Scale (ICAPS)}

The ICAPS is a 55-item self-report online survey developed by David Matsumoto and colleagues in 2001.4 Its items use a seven point Likert scale to measure intercultural competence by assessing four psychological skills. These include emotional regulation, openness, flexibility, and critical thinking. It produces one overall score and a score for each of the four assessed skills (Griffith, et al., p.8; Bücker and Poutsma, 2010, pp.273, 285; Matsumoto

\footnotetext{
${ }^{4}$ Readers should note that Dr. Matsumoto is the lead author for a review of assessment instruments, which this article uses as a source.
} 
\& Hwang, 2013, p.863; Cartwright, 2016, p.36). According to Matsumoto, the ICAPS literally measures the capacity to adjust, looking at both personality traits and metacognitive processing (Bücker and Poutsma, 2010, p.275). Unlike some instruments, the ICAPS is designed to account for cultural equivalence, specifically between Japanese and English-speaking cultures (Bücker and Poutsma, 2010, p.285).

The ICAPS has marginal construct validity overall; some convergent and divergent validities; adequate content validity; and most importantly, extensive concurrent and predictive ecological validity (Griffith, et al., 2016, p.16; Matsumoto \& Hwang, 2013, pp.857-868; Bücker and Poutsma, 2010, p.285). Like the MPQ, it has shown incremental predictive validity over standard personality and intelligence scales. It has also demonstrated adequate internal and testretest reliability, as well as reliability across other languages (Matsumoto \& Hwang, 2013, pp.864-865, 867-868; Bücker and Poutsma, 2010, p.285). It is available from Humintell for $\$ 69$ as part of their "Intelliculture Module 4 - Leveraging Cultural Differences" as seen on https://www.humintell.com/improving-your-global-skills/, accessed on 6 July 2019.

\section{Cultural Intelligence Scale (CQS)}

Cultural intelligence (CQ) is a construct with motivational, conative, and cognitive aspects. The term refers to a set of capabilities considered to be important for successful intercultural interaction. Dr. Soon Ang and colleagues defined CQ in articles beginning in 2003 and subsequently developed the CQS in 2007. The CQS is a 20-item, online self-assessment survey using seven-point Likert scales to examine four factors and their interrelationships: strategy, knowledge, motivation, and behavior. The CQS has been tested across multiple cultures, and there is a version for 360 degree assessment (Cartwright, 2016, p.34; Griffith, et al, 2016, p.8; Bücker and Poutsma, 2010, pp.273-274, 284; Matsumoto \& Hwang, 2013, pp.855, 865, 868). 
In testing, the CQS has shown structural, convergent, and divergent validity (Griffith, et al., 2016, p.17; Matsumoto \& Hwang, 2013, pp.856) as well as adequate content validity and strong concurrent and predictive validity (Matsumoto \& Hwang, 2013, pp.856, 863-868). Like the MPQ and ICAPS, it has incremental predictive validity over personality factors and intelligence. It has also proven reliable (Griffith, et al., 2016, p.17; Bücker and Poutsma, 2010, p.284; Matsumoto \& Hwang, 2013, pp.856, 868).

The self-report form of the CQS is available for $\$ 60$ at the Cultural Intelligence Center (https://culturalq.com/, accessed 6 July 2019). Upon completion, the respondent receives an explanatory report, which includes ratings and norms for the four cultural intelligence capabilities and 13 sub-dimensions. It also includes the respondent's cultural value preferences and the shell of a development and action plan for use in further developing cultural intelligence. If the subject uses both the self-report and the 360 degree assessment, the resulting report will compare the consolidated responses of others against the subject's own.

\section{Intercultural Development Inventory (IDI)}

The reader should first note that the authors of two of the primary meta-review sources, R. Michael Paige and Douglas Stuart, employ the IDI commercially. They have also provided positive testimonials on idiinventory.com, the website for the IDI Limited Liability Corporation, which is a component of Hammer Holdings, Incorporated (The roadmap to intercultural competence using the IDI: success stories: testimonials, 2019).

Mitchell Hammer and Milton J. Bennett developed the IDI in the mid-1990s using Bennett's Development Model of Intercultural Sensitivity (DMIS) as the foundational construct. The IDI is a self-report survey instrument. It uses 50 five-point Likert scale items to place respondents at one of five (formerly six) stages of an intercultural development continuum. The stages are 
denial, defense (or polarization), minimization, acceptance, and adaptation. The continuum is really measuring how the respondents view, understand, and react to cultural differences (Stuart, 2008, p.182; Cartwright, 2016, p.37; Perry \& Southwell, 2011, p.460; Matsumoto \& Hwang, 2013, p.860; Paige, 2004, p.99; Griffith, et al., 2016, p.8). This is essentially metacognition and cognitive processing (Bücker and Poutsma, 2010, pp.273-274).

Organizations currently use the IDI in selection for cross-cultural assignments, but also for assessment of training effectiveness and of intercultural competence among groups, such as audiences or leadership teams. The IDI also supports training and developmental planning by helping identify the most effective kind of intervention for increasing intercultural competence (Stuart, 2008, p.182; Cartwright, 2016, p.37; Perry \& Southwell, 2011, 460; Paige, 2004, pp.88, 99).

However, only a trained interpreter, certified through a three-day seminar, can score the IDI and thus generate the detailed feedback necessary for that degree of utility (Paige, 2004, pp. 91, 100; Stuart, 2008, p.182). That is not the only identified drawback to the IDI. Perry and Southwell argue that the linear, five-stage continuum oversimplifies the process of developing intercultural competence, especially since the continuum by itself (i.e., without the interpreter) provides no detail of the dimensions measured (2011, p. 461).

Studies have found the IDI to have adequate content validity and high internal reliability (Matsumoto \& Hwang, 2013, pp.860, 863; Paige, 2004, p.99; Griffith, et al., 2016, p.17). It has also proven resistant to bias due to gender, age, education, or social desirability. (Griffith, et al., 2016, p.17; Paige, 2004, p.91). Studies have shown that IDI scores correlate positively with "worldmindedness," degree of prior intercultural experience, number of friends from other cultures, and satisfaction with intercultural experiences. IDI correlates negatively with 
intercultural anxiety. These results strongly support IDI's construct validity and to a lesser degree, its ecological validity (Matsumoto \& Hwang, 2013, p.860; Paige, 2004, p. 99; Griffith, et al., 2016, pp. 21-22). Studies on the IDI's utility for training assessment have had mixed results (Matsumoto \& Hwang, 2013, p.860), but other factors in the training curriculum or training audience may have contributed.

According to idiinventory.com, an individual can take an IDI for $\$ 12-\$ 30$ and have unlimited access to reports. However, the three-day seminar qualifying someone to administer and score the inventory costs between $\$ 1600$ and $\$ 2000$. Prices vary depending on whether the purchaser represents an educational institution, a non-profit, or another organization. Consultants specializing in intercultural training and assessment will provide price quotes on request for administering and scoring the IDI. Organizations choosing to use the IDI are obliged to compare those fees with the costs of developing the capability to do so in-house.

\section{Honorable Mentions}

Three instruments met the criterion for inclusion in sufficient scholarly comparisons, but lacked scope, testing or a body of generally successful testing. Those three are the Intercultural Sensitivity Inventory (ICSI), the Intercultural Sensitivity Scale (ISS), and the Behavioural Assessment Scale for Intercultural Competence (BASIC). They warrant mention, if not full review.

Like most of the instruments reviewed herein, the ICSI is Likert scale-based self-report survey. However, it is unique in that it is only measuring two personality traits (flexibility and open-mindedness) and one cultural value orientation (individualism versus collectivism). The ICSI's internal reliability is high. However, its ecological validity testing is limited, and the results of that testing are mixed. It is primarily used in training (Cartwright, 2016, p.38; Bücker 
and Poutsma, 2010, pp.275, 286; Matsumoto \& Hwang, 2013, pp.859-866; Paige, 2004, p.100; Griffith, et al, 2016, pp.11, 20).

However, given the narrow measurement scope of the ICSI, the fact that it demonstrated even mixed validity indicates that the aspects its creators (Bhawuk and Brislin) chose to measure are genuinely critical. Bhawuk and Brislin claim that "a good approach to measuring intercultural sensitivity is to determine people's knowledge about and willingness to change behaviours related to the individualistic or collectivistic background of others (Bhawuk \& Brislin, 1992, p.418)." They also determined that three years of experience in a foreign culture increases intercultural sensitivity, and a willingness to eat food from diverse cultures signals such sensitivity (Bücker and Poutsma, 2010, p.275). Such intriguing findings indicate that their research merits further scholarly attention.

True to its name, the ISS measures intercultural sensitivity, which its creators (Chen and Starosta, 2000) limit to the affective aspect of intercultural competence, excluding behavior or skills (Perry \& Southwell, 2011, pp.453, 461). It is yet another Likert scale self-report survey for which testing has demonstrated high internal reliability overall, but in this case, not every subscale has done so. Only two studies support its ecological validity. Among U.S. students, they show correlations with attitudes toward intercultural communication and intercultural decision quality (Griffith, et al, 2016, pp.8, 17; Matsumoto \& Hwang, 2013, pp.861-866; Perry \& Southwell, 2011, p.461). In sum, this is another promising instrument of narrow scope and limited research support.

The BASIC is noteworthy in that it is the only purely qualitative instrument in this metareview, despite the fact that researchers lament both the need for more qualitative measurement tools (Matsumoto \& Hwang, 2013, p.868) and the importance of mixed methods of assessment 
(Deardorff, 2006, p.250; Fantini, 2009, p.465). Researchers Koester and Olebe developed the BASIC by revising a previous assessment tool known as the Intercultural Behavioral Assessment (IBA) (Matsumoto \& Hwang, 2013, pp.856, 857). The IBA was designed to be easily administered by untrained observers (Matsumoto \& Hwang, 2013, p.866). The BASIC similarly relies on peer ratings and a Likert scale that is unique among those listed in this metareview; it uses a four-point scale and behavioral descriptions (Griffith, et al, 2016, pp.10, 12). Andrea Graf and Lynn K. Harland suggest that the BASIC is most useful for assessing "the degree to which a person tends to judge and interact with people from different cultures in a respectful, empathetic and non-evaluative way" (2005, p.57).

There is conflicting reporting on the internal reliability of the overall BASIC scale, and it has significant construct and content validity issues (Matsumoto \& Hwang, 2013, p.857, 863-864; Griffith, et al, 2016, pp.15, 19) There is some evidence on the BASIC's ecological validity, but each of the three studies that found such evidence was extremely limited in either sample or scope (Matsumoto \& Hwang, 2013, pp.865-866)

In addition to these, some commercially exploited instruments (Bücker \& Poutsma, 2010, p.272) are barely mentioned in academic reviews because they are not easily accessible to researchers. Among these, three stand out as having significant suitability for selection of overseas assignees and high credibility overall: the Self-Assessment for Global Endeavors (SAGE); the Tucker Assessment Profile (TAP, a redevelopment of the Overseas Assignment Inventory, or OAI); and the Global Competencies Inventory (GCI). 5

The SAGE is a three-part instrument developed by well-known researcher Paula Caligiuri. The first two sections assess personality traits and motivation of both an expatriate candidate and

\footnotetext{
${ }^{5}$ This selection does not imply a judgment against other commercially available instruments. The three listed are the three most suitable for which there is information outside of marketing literature.
} 
a partner with whom he or she intends to travel. The third section is not for assessment. It is an aid to facilitate family conversation about an assignment abroad. The SAGE is designed to aid self-selection, but the results can also shape a bespoke training program (Stuart, 2008, p.181; IOR Global Services, p.3).

The GCI and the TAP also have strong pedigrees, also support training development, and claim greater compatibility with formal human resources assessment than the SAGE. All three have an online survey component, but the GCI and the TAP each require a conversation with a trained facilitator - for debriefing in the case of the GCI, and for a behavioral assessment interview for the TAP. The TAP interview functions as a qualitative, dialogue-based assessment that meets the recommendation to use mixed measures. Purveyors of these three tools tout their validity and reliability. They offer documentation of those claims upon request (Stuart, 2008, p.181; Griffith, et al, pp. 8, 15, 17, 21; IOR Global Services, p.3).

The survey component of these instruments seems to offer little that is not available from those reviewed in more detail above. It is more useful to view them as part of the suite of tools offered by global relocation and talent development service providers. These companies offer assessment, cultural and language training, consultation, and repatriation support to individuals, families, and corporations confronted with the challenges of international assignments.

Examples include Aperian Global, Kozai Group, IOR Global Services, and Tucker International, among others (Cartwright, 2016).

\section{Conclusions, Recommendations, and Learning More}

Clearly, there are many ways to identify candidates for international assignment and assess their intercultural competence. The overview and the meta-review above considered validity, reliability, utility for the selection process, cost in time and money, and ease of use. Some 
require too much time and expertise to be cost-effective outside academic settings, such as works of creative self-expression. Self-assessment instruments are at the opposite end of the spectrum for ease of use, but additional assessments using outside observers and qualitative methods should be employed to corroborate their findings.

Other important factors in expatriate selection include the risks associated with the decision, the resources available, and the magnitude of the requirement in both size and time. Questions regarding the magnitude include, "How big is the candidate pool? How many assignees are required? Is this a one-time requirement, or a recurring one?" If risks and resources are low, an organization may choose methods that take little time or money but are still likely to be effective. In particular, an organization that is experimenting with overseas assignments - perhaps a company in its first joint venture with a foreign firm - may establish a minimal assessment process for use in the near term.

An organization may also attempt to reduce risks by spending more resources on assessments and training. For larger, more enduring requirements, organizations can achieve economy of scale by developing in-house assessments and training expertise. They can also partner with full service international mobility specialists for an even wider array of services. These firms employ intercultural competence specialists who are generally qualified in both assessment and training.

Intercultural competence has proven somewhat malleable in that education, training, and experience can significantly improve it, although there is no consensus regarding the best methods of doing so (Griffith, et al, 2016, p.6-7; Mesmer-Magnus \& Viswesvaran, 2008, p.185). For this reason, some researchers suggest that a candidate should complete assessments prior to training in order to tailor the curriculum; however, one meta-analysis concluded that this rarely 
occurs (Feitosa, et al, 2014, p.142). While time-consuming and expensive, language and cultural training (both culture-general and culture-specific to the host nation) are generally necessary investments - even more so if the cultural distance between the sending and receiving societies is high. An international news outlet or a multinational sales force may need to send personnel to many different cultures. In such cases, the need for language and culture training specific to each host nation will likely compel some level of outsourcing.

Of the self-report surveys, the MPQ, ICAPS, and CQS demonstrated exceptional validity and reliability within an already select group. They are inexpensive, require no special expertise to administer, and generate self-explanatory reports. However, each one is inadequate as a sole method of assessment, and they may even be inadequate in toto. The consensus of experts recommends not only multiple methods of assessment, but both quantitative and qualitative methods.

The CCAI and CQS each offer 360 degree options which counter the biases associated with self-reporting. Dialogue-based assessments or case study analysis are two qualitative options. Using almost no additional resources, a trained assessor can conduct these assessments in a few hours and complete a report in a few days. Organizations can also use business trips overseas as opportunities to observe performance. Ideally, an expert assessor from the human resources department would travel to perform the observation, but many organizations will not have that option. However, observation by even an untrained observer - especially one with experience in the host culture - may be significantly better than no qualitative assessment at all. For the same reason, the BASIC, despite its validity issues, is another qualitative option.

In addition to formal assessments of intercultural competence, there are other indicators that correlate with successes in international assignments. General mental ability (IQ) is one, perhaps 
in part because intelligence assists in navigating complexity. Prior successful experience overseas also correlates consistently with subsequent performance, as it indicates both motivation and ability (Mesmer-Magnus \& Viswesvaran, 2008, p.185). The emotional intelligence construct (EQ) may overlap with intercultural competence even more significantly than IQ, and recent research has worked to better define the overlap and disambiguate the two (Conrad, 2006; Guntersdorfer \& Golubeva, 2018; Altaras Dimitrijević, Starčević, \& Jolić Marjanović, 2019).

It is worth repeating that any assessment and selection procedure must consider more than professional competence and intercultural competence. The expectations, motivation, requirements, and personal circumstances of the candidate and the candidate's family are also key. A detailed discussion of these factors is beyond the scope of this paper, but they can limit the candidate pool significantly and reduce the assessment requirement. Emerald Publishing's Journal of Global Mobility and SAGE Publications' Essentials of International Human Resource Management are good places to start learning more, but there are many other sources. Global mobility consultants also offer relevant expertise. Some, such as Tucker International, provide instructive content free of charge via their websites.

One effective way to start the conversation is to offer an opportunity for intercultural competence self-assessment. Self-assessment can spark interest in employees who had previously never considered international assignments. They may then explore their options within the organization and discuss them with their families. As part of onboarding, organizations with a significant overseas component can provide new hires one or more of the quick, inexpensive self-report surveys discussed in this paper. Those new hires can choose whether or not to share the results with their employer. In this scenario, the employer would 
explicitly state that sharing the results is a non-binding way to express interest in learning more about international assignments.

Expatriate assignments have a tremendous impact on both organizations and individuals, and there are more factors than just assessments, selections, and development affecting their success, such as support, communication, management, and repatriation. Valuable experiential lessons and relevant research findings are available on all these topics, but they must be sought out and applied. Expatriate success garners prodigious opportunities, but the risk of costly failure is high. These facts justify the expenditure of time, money, and attention to get international assignments right.

\section{References}

Altaras Dimitrijević, A., Starčević, J., \& Jolić Marjanović, Z. (2019). Can ability emotional intelligence help explain intercultural effectiveness? incremental validity and mediation effects of emotional vocabulary in predicting intercultural judgment. International Journal of Intercultural Relations, 69, 102-109.

Bhawuk, D. P., \& Brislin, R. (1992). The measurement of intercultural sensitivity using the concepts of individualism and collectivism. International Journal of Intercultural Relations, 16(4), 413-436.

Bird, A., Mendenhall, M., Stevens, M. J., \& Oddou, G. (2010). Defining the content domain of intercultural competence for global leaders. Journal of Managerial Psychology, 25(8), 810-828.

BGRS, AKA Brookfield Global Relocation Services. (2016). Breakthrough to the future of global talent mobility. Global Mobility Trends Survey. Retrieved from http://globalmobilitytrends.bgrs.com/ on 14 August 2018. 
Bücker, J., \& Poutsma, E. (2010). How to assess global management competencies: An investigation of existing instruments. Management Revue, 263-291

Byrne, B. M. (2000). Structural equation modeling with AMOS : Basic concepts, applications, and programming. Mahwah, N.J.: Psychology Press.

Cantele, M., Groeschke, D., Sandu, O. N., \& Barrett, M. (2015). Assessment of Intercultural Learning - Principles, Practices and Challenges: A Summary of the Outcomes of Four Workshops. Intercultura, 76, 23-24. Retrieved from https://www.academia.edu/28260382/Assessment_of_intercultural_learning_principles_p ractices_and_challenges_A_summary_of_the_outcomes_of_four_workshops on 4 February 2018.

Cartwright, C. (2016). Frequently used assessment tools. Handout at the 103rd annual meeting of the Association of American Colleges and Universities (AACU) in San Francisco, CA on 28 January 2017. Linked as discussion handout 2 on https://www.aacu.org/meetings/annualmeeting/AM17/resources or directly accessible at https://www.aacu.org/sites/default/files/files/AM17/Cartwright\%20Handout\%202.pdf.

Chi, R., \& Suthers, D. (2015). Assessing intercultural communication competence as a relational construct using social network analysis. International Journal of Intercultural Relations, 48, 108-119.

Collings, D. G., Scullion, H., \& Morley, M. J. (2007). Changing patterns of global staffing in the multinational enterprise: Challenges to the conventional expatriate assignment and emerging alternatives. Journal of World Business, 42(2), 198-213.

Conrad, J. E. (2006). The relationship between emotional intelligence and intercultural sensitivity (Doctoral dissertation, University of North Florida). Retrieved from 
https://search-proquest-

com.ezproxy.lib.usf.edu/docview/304909635/fulltextPDF/7FB4D84055004297PQ/1?acc ountid $=14745$

Deardorff, D. K. (2011). Assessing intercultural competence. New Directions for Institutional Research, 2011(149), 65-79.

Deardorff, D. K., \& Deardorff, D. L. (2007). An overview of the basic methods of outcomes assessment. In M. C. Bolen (Ed.), A guide to outcomes assessment in education abroad (pp. 89-96). Carlisle, PA: Forum on Education Abroad.

Dervin, F. (2010). Assessing intercultural competence in language learning and teaching: A critical review of current efforts. New Approaches to Assessment in Higher Education, 5, $155-172$.

Fantini, A. E. (2006). Assessment tools of intercultural communicative competence. Federation of the experiment in international living: occasional papers. Retrieved 2 May 2018, from file:///C:/Users/capta/Downloads/feil_appendix_f\%20(1).pdf

Fantini, A. E. (2009). Assessing intercultural competence: Issues and tools. In D. K. Deardorff (Ed.), The SAGE Handbook of Intercultural Competence (pp. 456-476). Thousand Oaks, CA: Sage.

Feitosa, J., Kreutzer, C., Kramperth, A., S. Kramer, W., \& Salas, E. (2014). Expatriate adjustment: Considerations for selection and training. Journal of Global Mobility, 2(2), 134-159.

Gertsen, M. C. (1990). Intercultural competence and expatriates. The International Journal of Human Resource Management, 1(3), 341-362. 
Graf, A., \& Harland, L. K. (2005). Expatriate selection: Evaluating the discriminant, convergent, and predictive validity of five measures of interpersonal and intercultural competence. Journal of Leadership \& Organizational Studies, 11(2), 46-62.

Griffith, R. L., Wolfeld, L., Armon, B. K., Rios, J., \& Liu, O. L. (2016). Assessing intercultural competence in higher education: Existing research and future directions. research report. ETS RR-16-25. ETS Research Report Series, Retrieved from https://search.proquest.com/docview/1895975717?accountid=14745

Guntersdorfer, I., \& Golubeva, I. (2018). Emotional intelligence and intercultural competence: Theoretical questions and pedagogical possibilities. UMBC Faculty Collection. Retrieved from https://mdsoar.org/handle/11603/11288

IOR Global Services. (2015). Assessment tools for global talent, or IOR Global Services Assessment_Collateral_with_Tools_Chart.pdf. IOR Global Services. Retrieved 24 March 2018 from www.iorworld.com.

Johnson, J. P., Lenartowicz, T., \& Apud, S. (2006). Cross-cultural competence in international business: Toward a definition and a model. Journal of International Business Studies, 37(4), 525-543.

Josien, L. (2012). Enhancing expatriate selection: Measuring the strength of acculturation. Journal of International Business Research, 11(1), 83.

KIT Royal Tropical Institute. (n.d.) Multicultural Personality Questionnaire (MPQ). Retrieved 29 July 2019 from https://www.kit.nl/service/multicultural-personality-questionnaire-mpq/ Kraimer, M., Bolino, M., \& Mead, B. (2016). Themes in expatriate and repatriate research over four decades: What do we know and what do we still need to learn? Annual Review of Organizational Psychology \& Organizational Behavior, 3, 83. Retrieved 
from http://ezproxy.lib.usf.edu/login?url=http://search.ebscohost.com/login.aspx?direct=t rue $\& \mathrm{db}=\mathrm{edb} \& \mathrm{AN}=113945133 \&$ site $=$ eds-live

Lieberman, D. A., \& Garnst, G. (2015). Intercultural communication competence revisited:

Linking the intercultural and multicultural fields. International Journal of Intercultural Relations : IJIR, 48, 17. Retrieved from

https://search.proquest.com/docview/1710664123?accountid=14745.

Linville, M. W. (2012). An Examination of How Personality Factors Influence the Adaptability of U.S. National Leaders in Expatriate Contexts. (Dissertation). Indiana Wesleyan University in Marion, Indiana.

Matsumoto, D., \& Hwang, H. C. (2013). Assessing cross-cultural competence: A review of available tests. Journal of Cross-Cultural Psychology, 44(6), 849-873.

McNulty, Y., De Cieri, H., \& Hutchings, K. (2013). Expatriate return on investment in the Asia Pacific: An empirical study of individual ROI versus corporate ROI. Journal of World Business, 48(2), 209-221.

Mello, J. A. (2014). Strategic human resource management. Toronto: ON. Nelson Education.

Mesmer-Magnus, J. R., \& Viswesvaran, C. (2008). Expatriate management: A review and directions for research in expatriate selection, training, and repatriation. Handbook of Research in International Human Resource Management, 183-206.

Mokkink, L. B., Terwee, C. B., Patrick, D. L., Alonso, J., Stratford, P. W., Knol, D. L., de Vet, H. C. (2010). The COSMIN study reached international consensus on taxonomy, terminology, and definitions of measurement properties for health-related patientreported outcomes. Journal of Clinical Epidemiology, 63(7), 737-745. 
Nelson, P. (2019). The relationship of state fragility and Hofstede's index of cultural distance to cross-cultural adjustment of expatriates. Rosemead School of Psychology, Biola University, La Mirada, California.

Paige, R. M. (2004). Instrumentation in intercultural training. In Landis, D., Bennett, J., \& Bennett, M. (Ed.), Handbook of intercultural training (pp.85-128). Sage Publications.

Peltokorpi, V., \& Froese, F. J. (2012). The impact of expatriate personality traits on crosscultural adjustment: A study with expatriates in japan. International Business Review, 21(4), 734-746.

Pennington, D. (2018). Essential personality. Abingdon-on-Thames: UK. Routledge.

Perry, L. B., \& Southwell, L. (2011). Developing intercultural understanding and skills: Models and approaches. Intercultural Education, 22(6), 453-466.

Ponterotto, J. G., Costa-Wofford, C. I., Brobst, K. E., Spelliscy, D., Kacanski, J. M., Scheinholtz, J., \& Martines, D. (2007). Multicultural personality dispositions and psychological wellbeing. The Journal of Social Psychology, 147(2), 119-135.

Selmer, J. (2001). The preference for predeparture or postarrival cross-cultural training-an exploratory approach. Journal of Managerial Psychology, 16(1), 50-58.

Sercu, L. (2004). Assessing intercultural competence: A framework for systematic test development in foreign language education and beyond. Intercultural Education, 15(1), 73. Retrieved from http://ezproxy.lib.usf.edu/login?url=http://search.ebscohost.com/login.aspx?direct=t rue $\& \mathrm{db}=\mathrm{edb} \& \mathrm{AN}=13310020 \&$ site $=$ eds-live 
Stuart, D. (2008). Assessment instruments for the global workforce. In M. Moodian (Ed.), Contemporary Leadership and Intercultural Competence, (pp. 175-190). Sage Publications.

Sutton, R. C., Miller, A. N., \& Rubin, D. L. (2007). Research design in assessing learning outcomes of education abroad programs. In M. C. Bolen (Ed.), A guide to outcomes assessment in education abroad (pp. 89-96). Carlisle, PA: Forum on Education Abroad.

Tamas Consultants. (n.d.). Description of the Multicultural Personality Questionnaire (MPQ). Tamas Consultants. Retrieved July 29, 2019, from www.tamas.com/sites/default/files/MPQ.pdf.

The roadmap to intercultural competence using the IDI: success stories: testimonials. (2019). Retrieved from https://idiinventory.com/success-stories/testimonials/.

Van der Zee, K., Van Oudenhoven, J. P., Ponterotto, J. G., \& Fietzer, A. W. (2013). Multicultural personality questionnaire: Development of a short form. Journal of Personality Assessment, 95(1), 118-124.

Wang, Y., \& Kulich, S. J. (2015). Does context count? developing and assessing intercultural competence through an interview- and model-based domestic course design in china. International Journal of Intercultural Relations : IJIR, 48, 38. Retrieved from https://search.proquest.com/docview/1710664215?accountid=14745

Yu, H. (2012). Intercultural competence in technical communication: A working definition and review of assessment methods. Technical Communication Quarterly, 21(2), 168-186. 


\section{Reviewer Appendix}

\section{Background}

For this reviewer, military experience overseas and subsequent personal research drove home both the criticality of intercultural competence and the staggering lack of attention it receives in practice. A conversation with Dr. Sean Ryan (Colonel, U.S. Army Special Forces, retired) confirmed my suspicions that those conditions held true in both civil government and the private sector. Subsequent research as a student in the University of South Florida's Doctor of Business Administration program revealed that there was a burgeoning body of knowledge on intercultural competence in academia, as well as a surfeit of methods to assess it. My interest in practical utility led me to research which methods were most suitable for business. A final review by Dr. Dejun Kong of the University of South Florida helpfully identified areas for improvement.

\section{Protocol}

The meta-review in this article required relatively recent sources that had compared multiple cross-cultural assessment instruments. This author knew that such articles existed because the Lieberman and Garnst article (2015) in the bibliography (found in prior research) identified one (Matsumoto \& Hwang, 2013). The Deardorff and Fantini sources had also already arisen from previous research. To find such sources, I used University of South Florida Library access to ABI/INFORM Global, to simultaneously search anywhere within peer-reviewed, English language articles from the last ten years for combinations of the following terms:

- Intercultural competence

- Cross-cultural competence

- Intercultural adaptability 
- Cross-cultural adaptability

- Cultural intelligence

- Assessment

- Measurement

- Evaluation

- Instrument

The search returned 173 articles. Within those, I searched for "validity" and received 57 results, then searched within those returns for "reliability" and received 37 results. The results were unsatisfactory. So subsequent searches modified the terms - adding "validity" to the initial search terms, limiting years to the last two, then narrowing the search field to just the abstract. That yielded many studies on the cross-cultural validity of instruments measuring completely different competencies. Then, I simultaneously narrowed the search field to the title and the abstract and broadened the search terms to include variations of the original terms:

- Title (intercultural OR cross-cultural OR global)

AND

- Abstract (assessment OR assessing OR measurement OR measuring) AND

- Title (competence OR competency OR competencies OR awareness OR sensitivity OR adaptability OR adjustment)

AND

- Abstract (instruments OR instrumentation OR tools OR test OR tests) AND

- Abstract (review OR investigation) 
This actually yielded relevant sources, so the next search again expanded the terms (intercultural, cross-cultural, or global, asses*, instrumen*, test*)and narrowed the field to the title. The results from these final two searches, the bibliographies of those results, and sources identified through previous research, provided sufficient instrument review sources to conduct a meta-review. In addition to ABI/INFORM, Google Scholar and ProQuest enabled download. For specifics on individual instruments and their use, I referenced articles on that instrument alone as well as the work of those who have used it commercially. The end result was six peer-reviewed comparative reviews of intercultural competence instruments, four non-peer-reviewed inventories of instruments, and a host of supporting sources.

\section{Permissions}

No permissions were required. Quoted text was used within academic fair use policy. 


\section{APPENDIX 3:}

\section{METHODS OF ASSESSING INTERCULTURAL COMPETENCE FOR INTERNATIONAL ASSIGNMENTS: A REVIEW}

\section{EXEMPT DETERMINATION}

March 31, 2020

John Hennings

2915 Winding Trail Dr.

Valrico, FL 33596

Dear John Hennings:

On 3/30/2020, the IRB reviewed and approved the following protocol:

\begin{tabular}{|r|l|}
\hline Application Type: & Initial Study \\
\hline IRB ID: & STUDY000644 \\
\hline Review Type: & Exempt 2 \\
\hline Title: & $\begin{array}{l}\text { Phenomenological Study on Lived Experiences of Assigned } \\
\text { Expatriates }\end{array}$ \\
\hline Funding: & None \\
\hline Protocol: & $\bullet \quad$ corrected clean copy of Study644 protocol \\
\hline
\end{tabular}

The IRB determined that this protocol meets the criteria for exemption from IRB review.

In conducting this protocol, you are required to follow the requirements listed in the INVESTIGATOR MANUAL (HRP-103). 


\section{UNIVERSITY OF SOUTH FLORIDA}

\section{Please contact USF IT at help@usf.edu to set up your Box.com study folder before storing data on the cloud. You will need to include the name of the Principal Investigator (folder owner), study title, data to be stored, and a list of IRB-approved study team members in your email to USF IT.}

Please note, as per USF policy, once the exempt determination is made, the application is closed in BullsIRB. This does not limit your ability to conduct the research. Any proposed or anticipated change to the study design that was previously declared exempt from IRB oversight must be submitted to the IRB as a new study prior to initiation of the change. However, administrative changes, including changes in research personnel, do not warrant a modification or new application.

Ongoing IRB review and approval by this organization is not required. This determination applies only to the activities described in the IRB submission and does not apply should any changes be made. If changes are made and there are questions about whether these activities impact the exempt determination, please submit a new request to the IRB for a determination.

Sincerely,

Amanda Shelley

IRB Research Compliance Administrator 
APPENDIX 4:

WHAT IS INTERCULTURAL COMPETENCE AND WHY IS IT IMPORTANT TO BUSINESS?

John A. Hennings

Doctor of Business Administration program

Muma College of Business

University of South Florida

August 2018

Engaged Management Scholarship (EMS) Conference 2018

Philadelphia

Available in the SSRN eLibrary: http://ssrn.com/link/8th-Intl-Conf-Engaged-Mgmt-Scholarship.html

Management Research Network (MRN)

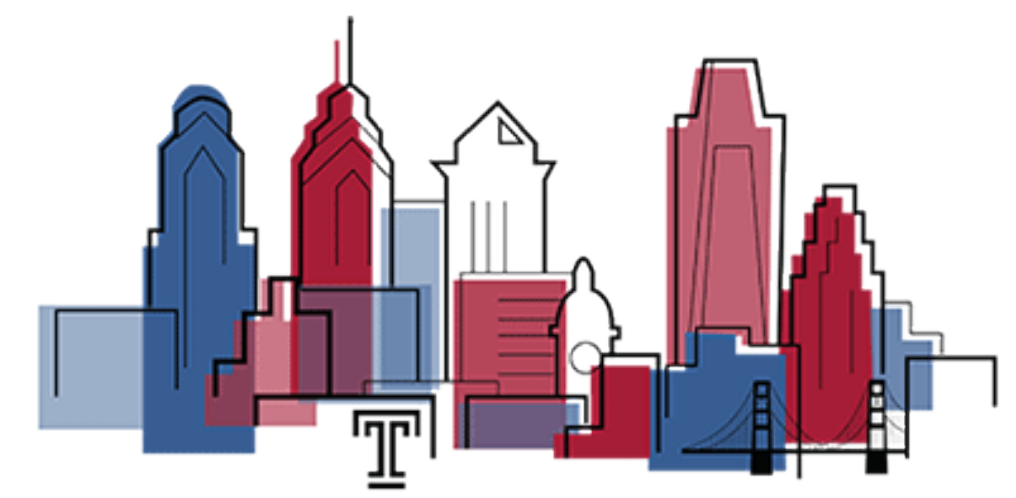

2018 ENGAGED MANAGEMENT SCHOLARSHIP CONFERENCE

TEMPLE UNIVERSITY | PHILADELPHIA, PA 


\title{
Tagline
}

In business and other endeavors, organizations must often collaborate internationally to accomplish their goals. Some individuals work across cultures more effectively than others, which can profoundly affect mission accomplishment. Business and psychology literature call this ability "intercultural competence," among other names. What is intercultural competence? Why is it important to businesses?

\author{
Keywords \\ Intercultural Competence \\ Intercultural Communication Competence \\ Intercultural Adaptability \\ Cross-cultural competence \\ Cultural Agility \\ Cultural Intelligence \\ Business Expatriate
}

\begin{abstract}
Some people are more effective than others at working with other cultures, and the success of international ventures can hinge on the difference. Business and psychology literature use various terms for this phenomenon. One common and telling example is "intercultural competence." This review distills a definition and a framework from the author's initial research into intercultural competence. This is in preparation for subsequent work developing criteria for selecting assessment methods and identifying assessment tools that are most useful for practice. The eventual goal is to develop a process which organizations can use to maximize business expatriates' chance of success.
\end{abstract}

Expansive searches in ABI/INFORM Global produced 274 peer-reviewed articles from which to derive a definition. Within the most relevant of those, the bibliographies yielded even more sources, including some of the most influential works in the field. Further culling based on relevance, currency, and times cited narrowed the list to 14 definitions. The synthesis of those became "the ability to grasp different cultures, interact appropriately with them, and work effectively within them." (This excludes other necessary qualities for business expatriates, such as professional competence.) Further investigation of the fourteen sources and their many works cited resulted in ten models. These became the root sources of a new model comprised of cognitive, affective, and conative dimensions encompassing a host of knowledge, skills, and attitudes.

\section{Introduction}

This study begins with an analytical review of existing literature on the concept of intercultural competence. The review supports the subsequent construction of a framework for intercultural competence and the identification of possible relationships between its dimensions. The resulting framework will be used to compare methods of assessment and identify those most suited for practice — specifically, companies intending to assign personnel internationally.

\section{Relevance}

People of similar training and experience vary widely in their effectiveness at collaborating across cultures. That difference is known as intercultural competence, among other names 
(Bartel-Radic, 2006; Bartel-Radic, 2013; Bücker \& Poutsma, 2010). Intercultural competence can be pivotal on a multinational enterprise (Johnson, Lenartowicz, \& Apud, 2006; McPherson \& Szul, 2008). In her 2006 study of "Intercultural Learning in Global Teams,” Anne BartelRadic cited research showing that "cross-cultural business practices and global markets... are fraught with a variety of intercultural difficulties.” She further explained that:

...International assignments often incur unnecessarily high costs, poor job performance, individual and family adjustment problems, and difficulties in maintaining productive and satisfying social relationships with people from the host culture. International jointventures and mergers frequently do not achieve the expected performance (Bauchard 2001, L’Hermitte 1998, Franck 2000). Cultural differences provide the greatest potential to hinder effective interaction within global teams (DiStefano/Maznevski 2000). A large body of research confirms that the predominant reason for such failure is not due to lack of managerial technical competence, but to the dynamics of intercultural experience (Cerdin/Peretti 2000, Clarke/Hammer 1995, Deller 1996). (650)

Bartel-Radic's first example in the excerpt above is of the failure of business expatriates, a topic with its own great body of academic and practitioner literature. McNulty and Brewster (2017) define business expatriates as "legally working individuals who reside temporarily in a country of which they are not a citizen in order to accomplish a career-related goal, being relocated abroad either by an organization, by self-initiation or directly employed within the host-country.”

Expatriate failure occurs when individuals on overseas assignments for their employers are ineffective at adjusting, building relationships, and accomplishing their appointed objectives. This often results in early return or separation from their organization. One widely cited estimate reports that $16-40 \%$ of expatriate assignments fail to accomplish the goals of the company. Estimates of early return rates vary widely in both number and specificity, ranging from $20 \%$ overall to 70\% from developing nation assignments (Graf \& Harland, 2005). Even assuming success, expatriation is the most expensive staffing option for multinationals (Selmer, 2001). Costs for a typical expatriate employee failure (lost business, preparation expenses, etc.) have been estimated at between $\$ 250,000$ and $\$ 1.25$ million. Furthermore, failure often significantly damages the careers and self-esteem of the once-promising assignees (Mesmer-Magnus \& Viswesvaran, 2008).

Nevertheless, an estimated 63\% of companies saw their total number of expatriate employees stay the same or increase between 2014 and 2015, and 75\% expected the number to stay the same or increase over the following two years (Brookfield, 2016). This is understandable, considering that as of 2007, over 900,000 multinational firms were in existence (Odell \& Spielman, 2009), and economic globalization continues despite efforts to the contrary. Successful expatriates facilitate the transfer of knowledge, enable better control of foreign branches, and enhance communication (Feitosa, et al, 2014). Companies see long-term expatriates as a way to create value and will forego less costly alternatives to do so (Collings, Scullion, \& Morley, 2007). In fact, many multinationals require international experience for advancement top senior management (Mesmer-Magnus \& Viswesvaran, 2008). 


\section{Contribution}

Research commonly cites lack of intercultural competence as a primary reason for expatriate failure (or more positively, intercultural competence as a driver of expatriate effectiveness) (Bird, Mendenhall, Stevens, Oddou, 2010; Gertsen, 1990; Johnson, Lenartowicz, Apud, 2001; Josien, 2012; Kraimer, Bolino, \& Mead, 2016; Peltokorpi \& Froese, 2012). However, despite a body of research recommending assessment of intercultural competence as a factor in development and selection of expatriate assignees, technical competence (which is admittedly also critical) continues to dominate selection criteria. In fact, intercultural competence is frequently not even formally considered, much less assessed (Graf \& Harland, 2005; Kraimer, Bolino, \& Mead, 2016; Mesmer-Magnus \& Viswesvaran, 2008; Peltokorpi \& Froese, 2012). This author's research into intercultural competence should apply to a range of situations, but its focus is support to further work on expatriate effectiveness.

In this review, the author will attempt two tasks:

1. Define intercultural competence.

2. Develop an integrated framework of the same.

These tasks will serve as a foundation for (at least) two subsequent tasks, begun since the completion of this paper:

1. Define criteria for intercultural competence assessment methods

2. Select those offering the broadest utility to expatriate selection and preparation.

The most important works in this field lament the multiplicity of concept names, definitions, and frameworks, and explicitly state that this lack of clarity hinders study of the concept. These include broad reviews that have attempted to consolidate the leading concepts and into a common definition and framework. Deardorff (2006), Abbe, Gulick, \& Herman (2007), and Johnson, Lenartowicz, and Apud (2006), all cited in this review, are the leading examples. However, this review is the first attempt to do so in at least five years. It is intended to be another step on the path to practical consensus.

This work also directly addresses the question of how to distinguish cognitive and metacognitive aspects of intercultural competence. Earley, Ang, Koh, and Van Dyne raised the topic in their several works on cultural intelligence, and Johnson, Lenartowicz, and Apud (2006) addressed it, but this review collectively covers those seminal works with those of this decade.

Finally, speaking of cultural intelligence (stylized as “CQ”) and its relatively recent prominence, this review directly compares CQ, as defined by the researchers that named it, with intercultural competence and other related concepts. The finding is that is essentially the same, involving practice as much as cognition. CQ is not a capacity to develop intercultural competence, as one might assume from the name.

The latter two tasks listed above- the criteria for assessment methods and the selection of those with the broadest utility - will contribute to practice more than scholarship. The results will enable businesses to increase their likelihood of success in both international assignments and international ventures writ large. Put more conservatively, the results will help them avoid the high costs of failure cited above. However, even these are preparatory steps for a still larger, subsequent objective-a methodology that organizations can use to maximize the effectiveness 
of business expatriates. This will require the incorporation of additional factors beyond intercultural competence.

\section{Protocol}

Pilot reviews confirmed what the literature explicitly stated: Multiple terms are used to describe the same or greatly overlapping abilities. The terms in use are generally combinations of an adjective - “cultural,” “cross-cultural,” or “intercultural” - and a noun - "adaptability,” “agility,” or "competence." To begin the review, this author used University of South Florida Library access to ABI/INFORM Global, to simultaneously search among peer-reviewed, English language articles for the following terms:

- $\quad$ Intercultural competence

- $\quad$ Cross-cultural competence

- Cultural competence

- Intercultural adaptability

- $\quad$ Cross-cultural adaptability

- $\quad$ Cultural adaptability

- Intercultural agility

- Cross-cultural agility

- $\quad$ Cultural agility

The search returned 274 articles - one from the nineteen seventies, two from the nineteen eighties, 11 from the nineteen nineties, 76 from the first decade of the twenty-first century, and 184 from the years between 2010 and 2017. Scanning the titles and abstracts confirmed that ABI/INFORM had effectively sorted them by relevance, resulting in the elimination of all but the first sixty. Sorting by decade and reading the abstracts more closely enabled the elimination of some of the earliest articles written before either terminology or the construct were as semisettled as they are now. For example, two of the oldest articles used "cultural competence" to indicate competence in a single culture without regard to adaptability across cultures. In the elimination of older articles, it was important to avoid culling any heavily cited, seminal works that were still relevant to the discussion.

$\mathrm{ABI} / \mathrm{INFORM}$ had correctly assessed the top three as highly relevant, and consequently they were retained. The next focus was on the number of times each work had been cited. Articles that were cited less than twenty times were eliminated, unless they were published within the last four years. The newest articles underwent close examination, because they represented the current state of research and had not yet had the same opportunity to be cited as older articles. At the end of the process, fifteen articles remained.

In addition to ABI/INFORM, Google Scholar and ProQuest enabled download. Close reading of the full text of those articles eliminated several more for both failing to include a definition and 
being narrowly focused on one application (e.g., medicine or social work). Several times in this process, multiple articles concurrently cited another that seemed highly relevant, but had not appeared in my search. When this occurred, that article was investigated and often added to the pool. This practice highlighted another, more recent concept appellation not included in the initial search: “cultural intelligence." The seminal works by the initial researchers on cultural intelligence became important later in the review.

The end result was fourteen articles, all with definitions of intercultural competence or largely equivalent constructs, and a wealth of material for further research.

To supplement the definition with a framework, the author returned to the same fourteen sources. Eight of the sources with clear definitions also used well-researched and robust models or frameworks - sometimes more than one. When multiple sources pointed to influential models in works outside the search results, those articles and the models they presented were added, increasing the pool of potential sources. When a source found through the initial, broad search depended on another source's model, the source found through ABI/INFORM was excluded in favor of its antecedent. This process resulted in 11 models, from which to derive one. 


\section{Literature Summary, Part 1: Definitions}

From the surviving sources, Table 1 below covers the breadth of constructs and their definitions.

Table 1: Definitions of Intercultural Competence and Closely-Related Constructs

\begin{tabular}{|c|c|c|c|}
\hline $\begin{array}{c}\text { Construct Type } \\
\end{array}$ & Definition & Sources & Comments \\
\hline 1. Intercultural competence & $\begin{array}{l}\text { "a person's ability to understand the specifics } \\
\text { of intercultural interaction and to adjust to } \\
\text { these specifics by actively constructing an } \\
\text { appropriate strategy for interaction" (italics in } \\
\text { original) }\end{array}$ & $\begin{array}{l}\text { Bartel-Radic } \\
\text { (2013) }\end{array}$ & $\begin{array}{l}\text { More focused on strategy for } \\
\text { interaction than earlier definition by } \\
\text { same author }\end{array}$ \\
\hline 2. Intercultural competence & $\begin{array}{l}\text { "the ability to understand the meaning of } \\
\text { intercultural interaction and the ability to } \\
\text { adapt one's behavior to these meanings in } \\
\text { order to produce efficient behavior" }\end{array}$ & $\begin{array}{l}\text { Bartel-Radic } \\
\text { (2006) }\end{array}$ & $\begin{array}{l}\text { More focused on behavior and } \\
\text { outcomes than later definition by } \\
\text { same author }\end{array}$ \\
\hline 3. Intercultural competence & $\begin{array}{l}\text { "the personal ability needed to communicate } \\
\text { and work efficiently in intercultural every-day } \\
\text { and business situations with members of } \\
\text { different cultural groups or in a foreign } \\
\text { cultural environment" }\end{array}$ & $\begin{array}{l}\text { Behrnd \& } \\
\text { Porzelt, (2012) }\end{array}$ & $\begin{array}{l}\text { Cited from Friesenhahn (2001) as } \\
\text { translated by Behrnd \& Porzelt. }\end{array}$ \\
\hline 4. Intercultural competence & $\begin{array}{l}\text { "the ability to function effectively in another } \\
\text { culture" }\end{array}$ & $\begin{array}{l}\text { Bird, } \\
\text { Mendenhall, } \\
\text { Stevens, \& } \\
\text { Oddou (2010) }\end{array}$ & \\
\hline 5. Cultural competence & $\begin{array}{l}\text { "the full 'set of congruent behaviors, attitudes, } \\
\text { and policies that come together in a system, } \\
\text { agency or amongst professionals and enables } \\
\text { that system, agency or those professionals to } \\
\text { work effectively in cross-cultural situations"” }\end{array}$ & $\begin{array}{l}\text { Brach \& Fraser } \\
\text { (2002) }\end{array}$ & Cited from Cross (1989) \\
\hline 6. Cultural intelligence & $\begin{array}{l}\text { "a specific form of intelligence focused on } \\
\text { capabilities to grasp, reason and behave } \\
\text { effectively in situations characterised by } \\
\text { cultural diversity" }\end{array}$ & $\begin{array}{l}\text { Bücker \& } \\
\text { Poutsma } \\
\text { (2010) }\end{array}$ & $\begin{array}{l}\text { Cited from Ang, et al (2007); adds } \\
\text { a tenth functionally equivalent } \\
\text { term; also includes Johnson's } \\
\text { definition of cross-cultural }\end{array}$ \\
\hline
\end{tabular}




\begin{tabular}{|c|c|c|c|}
\hline & & & $\begin{array}{l}\text { competence below and notes the } \\
\text { two constructs' similar emphasis on } \\
\text { effectiveness and active use }\end{array}$ \\
\hline $\begin{array}{l}\text { 7. Cross-cultural } \\
\text { adaptability }\end{array}$ & $\begin{array}{l}\text { "the ability to adapt to another culture with its } \\
\text { requirements, values, and belief" }\end{array}$ & $\begin{array}{l}\text { Chang, Yuan, } \\
\text { \& Chuang } \\
\text { (2013) }\end{array}$ & $\begin{array}{l}\text { Asserts that cross-cultural } \\
\text { adaptability "indicates the potential } \\
\text { for cross-cultural effectiveness" }\end{array}$ \\
\hline 8. Intercultural competence & $\begin{array}{l}\text { "the appropriate and effective management of } \\
\text { interaction between people who, to some } \\
\text { degree or another, represent different or } \\
\text { divergent affective, cognitive, and behavioural } \\
\text { orientations to the world" }\end{array}$ & $\begin{array}{l}\text { Holmes \& } \\
\text { O’Neill (2012) }\end{array}$ & \\
\hline $\begin{array}{l}\text { 9. Cross-cultural } \\
\text { competence }\end{array}$ & $\begin{array}{l}\text { "effectiveness in drawing on a set of } \\
\text { knowledge, skills, and personal attributes in } \\
\text { order to work successfully with people from } \\
\text { different national cultural backgrounds at } \\
\text { home or abroad" }\end{array}$ & $\begin{array}{l}\text { Johnson, } \\
\text { Lenartowicz, } \\
\text { \& Apud (2006) }\end{array}$ & $\begin{array}{l}\text { Within the business literature, the } \\
\text { most heavily cited work on the } \\
\text { topic - over } 200 \text { citations since } \\
2006\end{array}$ \\
\hline $\begin{array}{l}\text { 10. Cross-cultural } \\
\text { adaptability }\end{array}$ & $\begin{array}{l}\text { ability to “communicate effectively in a } \\
\text { culturally diverse environment" }\end{array}$ & $\begin{array}{l}\text { McPherson \& } \\
\text { Szul (2008) }\end{array}$ & \\
\hline $\begin{array}{l}\text { 11. Intercultural } \\
\text { competence }\end{array}$ & $\begin{array}{l}\text { "The ability to quickly and accurately } \\
\text { comprehend, then appropriately and } \\
\text { effectively act in a culturally complex } \\
\text { environment to achieve the desired effect- } \\
\text { without necessarily having had prior exposure } \\
\text { to a particular group, region or language" }\end{array}$ & $\begin{array}{l}\text { Miller \& } \\
\text { Tucker (2015) }\end{array}$ & $\begin{array}{l}\text { Cited from Selmeski (2009); } \\
\text { referred to as "the U.S. Air Force } \\
\text { definition" }\end{array}$ \\
\hline $\begin{array}{l}\text { 12. Intercultural } \\
\text { competence }\end{array}$ & $\begin{array}{l}\text { "'the ability to think and act in interculturally } \\
\text { appropriate ways' and with sensitivity to } \\
\text { 'relevant cultural differences'” }\end{array}$ & $\begin{array}{l}\text { Sandage \& } \\
\text { Jankowski } \\
(2013)\end{array}$ & $\begin{array}{l}\text { Cited from Hammer, Bennett, \& } \\
\text { Wiseman (2003) }\end{array}$ \\
\hline $\begin{array}{l}\text { 13. Cross-cultural } \\
\text { competence }\end{array}$ & $\begin{array}{l}\text { "the ability to quickly learn to operate } \\
\text { efficiently in any culture" }\end{array}$ & Turnley (2011) & \\
\hline $\begin{array}{l}\text { 14. Intercultural } \\
\text { competence }\end{array}$ & $\begin{array}{l}\text { "the ability to communicate appropriately and } \\
\text { effectively in international and cross-cultural } \\
\text { technical communication-situations based on } \\
\text { one's sensitivity, awareness, and skills" }\end{array}$ & Yu (2012) & $\begin{array}{l}\text { The article is specific to technical } \\
\text { communication, but cites the } \\
\text { broader literature; its definition is } \\
\text { applicable with the strikeout. }\end{array}$ \\
\hline
\end{tabular}




\section{Discussion, Part 1: Definitions}

Each definition specifies culturally diverse environments, situations, or groups, so interaction between or among distinct cultures is common to them all. Eleven of the fourteen speak of effectiveness or efficiency, strongly implying task accomplishment and achievement of goals. These two elements combine to form the simplest definition of the group, "the ability to function effectively in another culture." For "intercultural competence," this definition is circular and tautological. It tells the reader nothing she could not derive from the component words. Others go into far more detail, listing behaviors, attitudes, policies, knowledge, skills, and personal attributes. These are actually referencing the prevalent models of intercultural competence, addressed in the next section of this review.

So what words would add meaningful detail, without building a complete template? Several definitions reference communication, which is obviously important to working effectively across cultures. Others seem to assume communication as a subset of work, function, or operation. The rest speak of "interaction" - broader than mere transmission and reception, while still emphasizing the human interface that makes the cross-cultural aspect matter. Finally, six definitions reference essential cognitive work that precedes the effective behavior, with verbs like "understand," "comprehend," "grasp," think,” and "learn.” So, the fused definition of intercultural competence (for the purpose of this and any subsequent, related articles) is "the ability to grasp different cultures, interact appropriately within them, and work effectively." This suggests the various aspects of the construct without adding unnecessary detail.

It is important to note that while intercultural competence is generally necessary and often critical for success in international operations, it is not sufficient. Other qualities, such as professional competence and situational awareness, are also essential (Bartel-Radic, 2006, p.650; Johnson, Lenartowicz, \& Apud, 2006, p.526 ;Turnley, 2011, p.3). 


\section{Literature Summary, Part 2: Models}

Table 2 below summarizes the models described in the key source literature.

Table 2: Models of Intercultural Competence and Closely-Related Constructs

\begin{tabular}{|c|c|c|c|}
\hline $\begin{array}{c}\text { Construct } \\
\text { Type }\end{array}$ & Model & Source & Used By $^{1}$ \\
\hline $\begin{array}{l}\text { 1. Intercultural } \\
\text { effectiveness } \\
\text { and cross- } \\
\text { cultural } \\
\text { competence }\end{array}$ & $\begin{array}{l}\text { Based on extensive literature review, one of the most comprehensive models of } \\
\text { intercultural effectiveness. Cross-cultural competence (CCC, i.e., intercultural } \\
\text { competence) is only one factor. Describes CCC as having three dimensions: } \\
\text { - knowledge/cognition } \\
\text { - affect/motivation } \\
\text { - skills } \\
\text { Also includes antecedent variables (related to disposition, biography, and self/identity) } \\
\text { that other models describe as "traits"; the culture-specific variables of language and } \\
\text { regional knowledge; mediating situational and organizational (contextual) variables } \\
\text { such as cultural distance and organizational support; and three dimensions reflecting } \\
\text { outcomes: job performance and work adjustment, personal adjustment, and interpersonal } \\
\text { relationships. }\end{array}$ & $\begin{array}{l}\text { Abbe, } \\
\text { Gulick, \& } \\
\text { Herman } \\
\text { (2007) }\end{array}$ & $\begin{array}{l}\text { Turnley } \\
\text { (2011) }\end{array}$ \\
\hline
\end{tabular}

\footnotetext{
1 "Used By" in this instance means that the reference was based, in whole or in part, on the model referenced. Individual citations of the model sources by the definition sources (and vice versa) were significantly more numerous.
} 


\begin{tabular}{|c|c|c|c|}
\hline $\begin{array}{l}\text { 2. Intercultural } \\
\text { competence }\end{array}$ & $\begin{array}{l}\text { Cognitive dimension, or mindset - knowledge of culture-general frameworks, specific } \\
\text { cultures, identity development patterns, cultural adaptation processes, and cultural self- } \\
\text { awareness } \\
\text { Behavioral dimension, or skillset - ability to empathize, gather appropriate information, } \\
\text { listen, perceive accurately, adapt, build relationships, resolve problems, and manage social } \\
\text { interactions and anxiety } \\
\text { Affective dimension, or heartset (attitudes/motivation) - curiosity, initiative, } \\
\text { nonjudgmentalness, risk taking, cognitive flexibility, open-mindedness, tolerance of } \\
\text { ambiguity, flexibility, and resourcefulness }\end{array}$ & $\begin{array}{l}\text { Bennett, } \\
\text { J.M. (2009) }\end{array}$ & $\begin{array}{l}\text { Miller \& } \\
\text { Tucker } \\
(2015)^{2}\end{array}$ \\
\hline $\begin{array}{l}\text { 3. Intercultural } \\
\text { competence }\end{array}$ & $\begin{array}{l}\text { Six stages of developmental model for intercultural sensitivity (DMIS) } \\
\text { - First three (denial, defense, and minimization) are ethnocentric } \\
\text { - Second three (acceptance, adaptation, and integration) are ethnorelative }\end{array}$ & $\begin{array}{l}\text { Bennett, M. } \\
\text { J. (1993); } \\
\text { Bennet, M.J. } \\
\text { (2013) }\end{array}$ & $\begin{array}{l}\text { Sandage \& } \\
\text { Jankowski } \\
\text { (2013) cite } \\
\text { 1993; Miller } \\
\text { \& Tucker } \\
\text { (2015) cite } \\
2013\end{array}$ \\
\hline $\begin{array}{l}\text { 4. Intercultural } \\
\text { competence }\end{array}$ & $\begin{array}{l}3 \text { factors of } 17 \text { dimensions: } \\
\text { Perception Management (cognitive/perceptual) - nonjudgmentalness, inquisitiveness, } \\
\text { tolerance of ambiguity, cosmopolitanism, category inclusiveness } \\
\text { Relationship Management (other/relationship) - relationship interest, interpersonal } \\
\text { engagement, emotional sensitivity, self-awareness, social flexibility } \\
\text { Self Management factors (self/self-efficacy) - optimism, self-confidence, self-identity, } \\
\text { emotional resilience, non-stress tendency, stress management, interest flexibility }\end{array}$ & $\begin{array}{l}\text { Bird, } \\
\text { Mendenhall, } \\
\text { Stevens, \& } \\
\text { Oddou } \\
\text { (2010) }\end{array}$ & \\
\hline
\end{tabular}

\footnotetext{
${ }^{2}$ Miller \& Tucker (2015) cite an additional "model" from Ting-Toomey (1999), but Ting-Toomey describes this as a technique to operationalize intercultural competence and not a model at all.
} 


\begin{tabular}{|c|c|c|c|}
\hline $\begin{array}{l}\text { 5. Intercultural } \\
\text { 0competence }\end{array}$ & $\begin{array}{l}\text { Process model with } 4 \text { competence sub-domains as realized in an intercultural context: } \\
\text { - Professional - job knowledge, working experience, knowledge of infrastructure } \\
\text { - Strategic - organizational skills, problem solving, decision making, knowledge } \\
\text { management } \\
\text { - Social - adaptability, capacity for teamwork, empathy, tolerance, willingness to } \\
\text { initiate communication, ability to transmit and receive meta-communication } \\
\text { (implicit cues) effectively } \\
\text { - Individual - optimism, willingness to learn, resistance to stress and frustration, } \\
\text { tolerance of ambiguity }\end{array}$ & $\begin{array}{l}\text { Bolten } \\
(2006,2007)\end{array}$ & $\begin{array}{l}\text { Behrnd \& } \\
\text { Porzelt } \\
\text { (2012) }\end{array}$ \\
\hline $\begin{array}{l}\text { 6. Intercultural } \\
\text { competence }\end{array}$ & $\begin{array}{l}\text { Savior être (attitudes - foundational) - curiosity, openness, readiness to suspend disbelief } \\
\text { regarding own culture or others } \\
\text { Savoir (knowledge - interacts with savoir faire) - knowledge of general interaction } \\
\text { process, social groups in own and other cultures } \\
\text { Savior comprende (interpreting/relating - interacts with savior s'engager) - ability to } \\
\text { interpret symbols and events of other culture and relate to one's own culture and } \\
\text { experience } \\
\text { Savoir faire (discovery/interaction - interacts with savior) - ability to acquire knowledge } \\
\text { of cultural practices and put it into practice } \\
\text { Savoir s'engager (critical cultural awareness - interacts with savoir comprende) - ability } \\
\text { to evaluate perspectives, practices and products from multiple cultural perspectives, and } \\
\text { identify criteria for evaluation }\end{array}$ & $\begin{array}{l}\text { Byram } \\
(1997)\end{array}$ & $\begin{array}{l}\text { Holmes \& } \\
\text { O’Neill } \\
(2012)\end{array}$ \\
\hline
\end{tabular}




\begin{tabular}{|c|c|c|c|}
\hline $\begin{array}{l}\text { 7. Intercultural } \\
\text { communication } \\
\text { competence }\end{array}$ & $\begin{array}{l}\text { From three separate concepts of Chen and Starosta's, Yu assembles an intercultural } \\
\text { competence construct. } \\
\text { Sensitivity (affective) - people's desire to understand, appreciate, and accept cultural } \\
\text { differences (1997) } \\
\text { Awareness (cognitive) - "the understanding of culture conventions that affect how we } \\
\text { think and behave”' (2000) } \\
\text { Skills (behavioral, AKA adroitness to Chen \& Starosta) - communication skills " "such as } \\
\text { behavioral flexibility, interactional management, and verbal and nonverbal skills"' in } \\
\text { intercultural interactions (1998) }\end{array}$ & $\begin{array}{l}\text { Chen / Chen } \\
\text { and Starosta } \\
(1997,1998 \text {, } \\
\text { 2000) }\end{array}$ & Yu (2012) \\
\hline $\begin{array}{l}\text { 8. Intercultural } \\
\text { competence }\end{array}$ & $\begin{array}{l}\text { In-depth model portrayed as both pyramid (where some elements support others) and } \\
\text { process. } \\
\text { Requisite attitudes (foundational) - respect (valuing other cultures, cultural diversity); } \\
\text { openness (to intercultural learning and to people from other cultures, withholding } \\
\text { judgment); curiosity and discovery (tolerating ambiguity and uncertainty) } \\
\text { Knowledge and Comprehension (second layer) - cultural self-awareness; deep } \\
\text { understanding and knowledge of others' context, culture, worldviews, and their impact; } \\
\text { sociolinguistic awareness } \\
\text { Skills (second layer) - listen; observe; interpret; analyse; evaluate; relate } \\
\text { Desired Internal Outcome (informed frame of reference/filter shift) - adaptability (to } \\
\text { different communication styles and behaviors; adjustment to new cultural environments); } \\
\text { flexibility (selecting and using appropriate communication styles and behaviors; cognitive } \\
\text { flexibility); ethnorelative view; empathy } \\
\text { Desired External Outcome - Behaving and communicating effectively and appropriately } \\
\text { (based on one’s intercultural knowledge, skills, and attitudes) to achieve one’s goals to } \\
\text { some degree }\end{array}$ & $\begin{array}{l}\text { Deardorff } \\
\text { (2006) }\end{array}$ & $\begin{array}{l}\text { Holmes \& } \\
\text { O’Neill } \\
(2012)\end{array}$ \\
\hline
\end{tabular}




\begin{tabular}{|c|c|c|c|}
\hline $\begin{array}{l}\text { 9. Intercultural } \\
\text { competence }\end{array}$ & $\begin{array}{l}\text { This is one of the oldest and most widely referenced models. Gertsen uses intercultural } \\
\text { competence as part of a model of expatriate success. The model also includes professional } \\
\text { qualifications, contextual factors (e.g., health, physical environment), and family } \\
\text { adjustment. The dimensions and components of the intercultural competence factor are as } \\
\text { follows: } \\
\text { Affective (personality traits and attitudes) -empathy, openness, flexibility, tolerance, } \\
\text { self-confidence, patience, composure, optimism, independence, initiative, intelligence, and } \\
\text { freedom from prejudice } \\
\text { Cognitive (acquisition and categorization of cultural knowledge) - broad mental } \\
\text { categories - i.e., the ability to accept a high degree of difference between things, situations, } \\
\text { and concepts in the same category; knowledge of the foreign culture's values, norms, } \\
\text { conventions, and social organization } \\
\text { Behavioral (communicative and conative) - ability to identify and apply different styles } \\
\text { of verbal and non-verbal communication, especially to express the knowledge and attitudes } \\
\text { reflected in the other two dimensions }\end{array}$ & $\begin{array}{l}\text { Gertsen } \\
\text { (1990) }\end{array}$ & $\begin{array}{l}\text { Behrnd \& } \\
\text { Porzelt } \\
\text { (2012); } \\
\text { Johnson, } \\
\text { Lenartowicz, } \\
\text { \& Apud } \\
\text { (2006) }\end{array}$ \\
\hline
\end{tabular}




\begin{tabular}{|c|c|c|}
\hline $\begin{array}{l}\text { 10. Cross- } \\
\text { cultural } \\
\text { competence }\end{array}$ & $\begin{array}{l}\text { Comprehensive model, based on a review of many others, in a heavily cited article. } \\
\text { Explicitly acknowledges that while cross-cultural competence is an important factor, } \\
\text { external environmental or contextual factors (e.g., political, legal, geographic, context of } \\
\text { communication) and factors internal to the firm (e.g., production, management, marketing, } \\
\text { finance) are also key to the success or failure of an international business venture. Also } \\
\text { highlights the negative moderating influences of cultural distance, or the degree of } \\
\text { difference between the home and foreign cultures, and institutional ethnocentrism, the } \\
\text { firm's rigidity regarding its processes and its tendency to impose them on outsiders. The } \\
\text { model describes three categories of “antecedents” to cross-cultural competence and details } \\
\text { example (i.e., non-exhaustive) lists of traits for each antecedent. The traits of the first } \\
\text { antecedent, personal attributes, are more difficult to acquire through training and education } \\
\text { than those of the latter two. } \\
\text { Personal attributes (affective) - Values, beliefs, norms, and personality traits such as } \\
\text { flexibility, perseverance, self-efficacy, etc. } \\
\text { Personal skills (behavioral / conative) - Abilities (foreign language competence, } \\
\text { adaptability to cultural behavior norms, stress management, conflict resolution) and } \\
\text { aptitudes (capacities to acquire additional abilities within a skill-set) } \\
\text { Cultural knowledge (cognitive) } \\
\text { - General - (foundational) awareness of cultural differences, the components of } \\
\text { culture, how cultural values are learned, frameworks for understanding and } \\
\text { comparing cultures, and different contexts in which international business operates } \\
\text { - Specific } \\
\text { • Factual - history, politics, economics, sociology } \\
\text { • Conceptual - values and how they are reflected in behavior } \\
\text { - Attributional - heightened awareness of appropriate behavior enabling correct } \\
\text { attribution of individuals' behavior in the target culture } \\
\text { metacognitive approach addressing how individuals acquire and apply cultural knowledge. }\end{array}$ & $\begin{array}{l}\text { Johnson, } \\
\text { Lenartowicz, } \\
\text { \& Apud } \\
\text { (2006) }\end{array}$ \\
\hline
\end{tabular}




\section{Discussion, Part 2: Models}

The models in this portion of the review use the terms cross-cultural competence, cultural intelligence, intercultural communication, intercultural competence, intercultural effectiveness, or intercultural sensitivity. All but one list three to five dimensions of the construct along with traits for each dimension.

Milton J. Bennett's developmental model of intercultural sensitivity (DMIS) is the exception. Bennett's model maps the process by which one becomes interculturally competent, not the construct itself. It is consequently not relevant to this portion of my investigation, but it is a unique and useful contribution to the field. Excluding the DMIS, an integrated model can be constructed using three interacting dimensions with multiple components each.

\section{Affective Dimension}

This has to do with how one feels about culture in general and cultures in particular. A combination of personality traits and attitudes, listed below in Figure 1, comprise the affective dimension. The affective dimension is foundational, because it provides both motivation and capacity to develop the other two dimensions. As it involves values, interests, and how one views oneself and others, it can be more difficult to develop than the other dimensions.

\section{Cognitive Dimension}

The cognitive dimension involves three interacting facets - how one thinks about cultures, what one knows about cultures, and how one learns about cultures. Here, this author has aligned with the researchers who combine the cognitive and metacognitive aspects of the construct, because there is no consensus on the boundaries between the two. First, culture-general knowledge - a basic understanding of what culture is, how history and circumstances affect culture, and how culture affects human behavior - is critical. Culture-general knowledge should include understanding how culture influences one's own behavior, as well as that of others. This prevents normative judgment on behaviors that are not inherently normative - i.e., deciding that an action is "good" or "bad" when it is merely different, and its utility is dependent upon the situation and the objectives.

Culture-general knowledge must also include an understanding of the limits of cultural influence. Circumstances and personality traits often impel people to contradict their culture's behavioral norms. Understanding this reduces the likelihood of overgeneralization or stereotyping, which drive errors in communication and behavior attribution. Cultures are general, but individual human behavior is specific.

The second facet of the cognitive dimension, culture-specific knowledge, is particular to individual cultures. As Johnson, Lenartowicz, and Apud explain above, culture-specific knowledge encompasses not only the factual knowledge widely offered by courses on foreign cultures, but also deeper understanding of values and behavior. Culture-specific knowledge and culture-general knowledge inform one another, in the same way that one's grasp of grammar or linguistics enhances and is enhanced by the study of a foreign language.

The final facet of the cognitive dimension is comprised of perception and interpretation. How does one acquire, categorize, and assign meaning to new information about a culture, whether it is derived from research or human interaction? This facet strongly affects how quickly one 
learns to navigate and become effective within a particular culture. Optimal learning and adaptation occur when they are motivated and empowered by the affective dimension and informed by a high degree of both culture-general and culture-specific knowledge.

\section{Conative Dimension}

The conative dimension is about skills and behavior - how one speaks and acts. These are the competencies of self-management and interaction that enable relationship building and task accomplishment within and through a foreign culture.

Within this dimension, the base level is pure communicative skill - both verbal and non-verbal, the ability to speak and understand the local tongue and even "code switch" between groups and levels of formality. It includes active listening in reception and both articulacy and tone in transmission. It is helpful to have an eye for the similarities and differences between the use of body language, facial expression, and humor in the home and target culture.

The higher level of the conative dimension is about the use of that communicative skill toward a practical end, like the difference between dance and martial arts. It includes elicitation of information, negotiation, and conflict resolution, as well as internal communication such as anger and stress management.

The affective and cognitive dimensions are necessary, but insufficient for full realization of the conative dimension. Proficiency requires practice. 


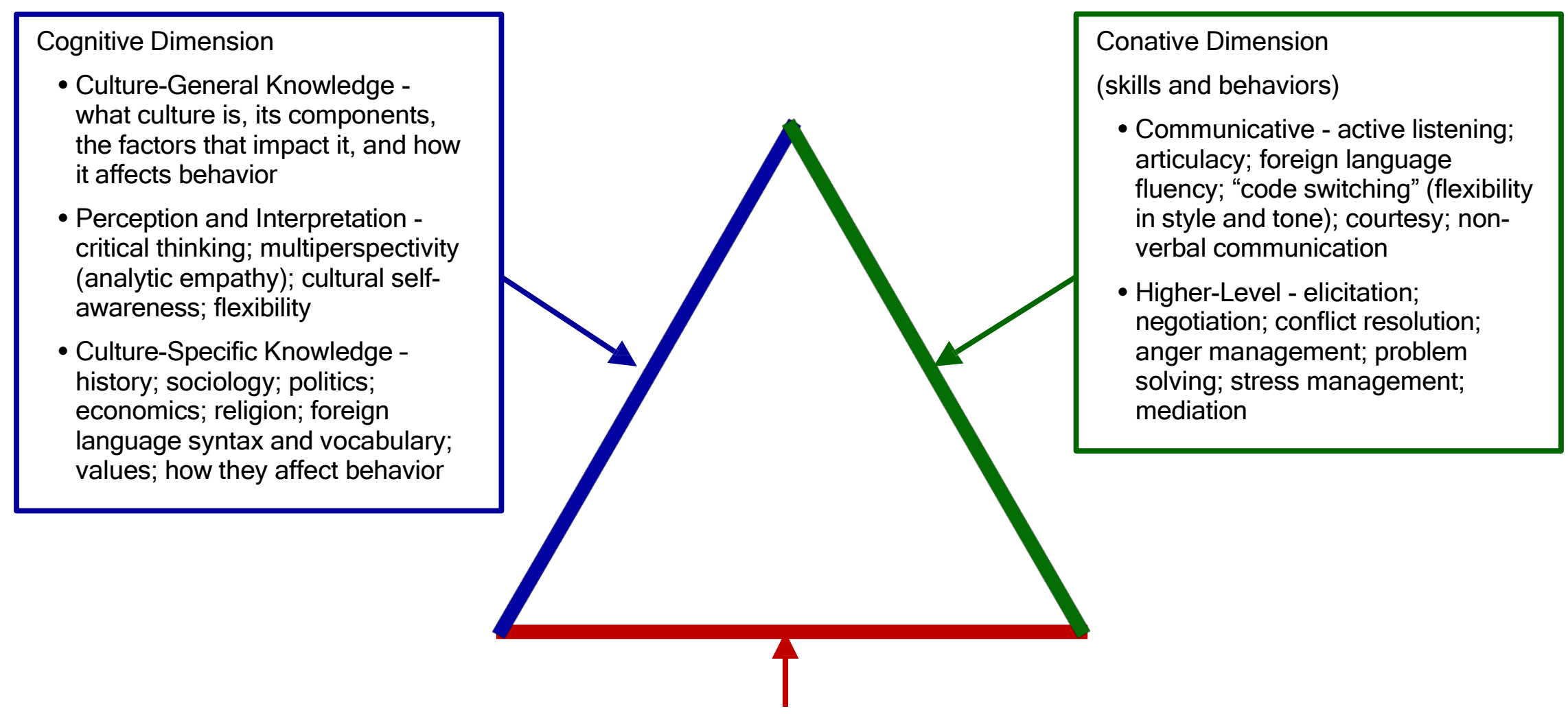

Affective Dimension (attitudes and traits) - Curiosity, respect, and openness toward cultures and individuals;

nonjudgmentalism; ambiguity tolerance; valuing diversity; initiative; persistence; empathy; optimism; self-awareness;

risk tolerance; resourcefulness; patience; independence; emotional resilience; self-efficacy

\section{Figure 1: Integrated Model of Intercultural Competence}


So three complex, interacting dimensions can effectively describe an individual's intercultural competence. But, as many of the above models point out, an individual's intercultural competence alone does not determine his or her effectiveness within a foreign culture. Internal factors such as health and technical or professional competence are as important in the new environment as they are in the old one. External factors such as the figurative distance between the home and target cultures; the ethnocentrism of or support from the sending organization; the market or other conditions affecting the work being attempted; and the intercultural competence of one's interlocutors all matter (Johnson, Lenartowicz, and Apud, 2006). In the case of an expatriate working overseas with her family, the family’s living circumstances, health, and intercultural competence also play significant roles (Abbe, Gulick, \& Herman, 2007).

Culture significantly impacts human thought, feelings, and behavior. Consequently, interaction between cultures affects collaborative work. However, it is still telling that in the panoply of variables listed above, intercultural competence stands out so strongly in the literature. That may be because many of the other important variables are equally important in the home environment, such as professional competence. Others are more intuitively obvious, such as cultural distance. Despite decades of study, the importance of intercultural competence seems to surprise many organizations (Brookfield, 2016).

An understanding of what intercultural competence is and why it is important quickly brings other questions to mind. How can organizations develop intercultural competence in their personnel? How can they evaluate intercultural competence, or even evaluate the capacity to develop intercultural competence? Researchers have plumbed these questions deeply with some positive result, but their answers are still quite incomplete, and there is no set formula for selecting and preparing employees for jobs requiring intercultural assignment (Deardorff, 2006; Josien, 2012; Kraimer, Bolino, \& Mead, 2016; Mesmer-Magnus \& Viswesvaran, 2008).

Expatriate assignments are only one subset of the many job positions in which intercultural competence is vital, but it is one that is of particular interest. Why do expatriate assignments across a myriad of fields require similar traits and skills for success? What is the essence of the expatriate work experience? Several recent articles have identified the nature of expatriate assignments as a topic requiring further research (Kraimer, Bolino \& Mead, 2016; McNulty \& Brewster, 2017; Shaffer, Kraimer, Chen, \& Bolino, 2012).

\section{Conclusions}

Intercultural competence (among other, related terms) describes the ability to understand other cultures and interact and work successfully both within and across them. This quality is far from universal, but increasingly vital in our globalizing world. Organizations within the public and private sector would benefit from increased understanding of intercultural competence, as well as methods for recognizing and fostering it. 


\section{References}

Abbe, A., Gulick, L.M., \& Herman, J. L. (2007). Cross-cultural competence in Army leaders: A conceptual and empirical foundation. Fort Leavenworth, KS: U.S. Army Research Institute for the Behavioral and Social Sciences, Leader Development Research Unit.

Bartel-Radic, A. (2006). Intercultural learning in global teams. Management International Review, 46(6), 647-678.

Bartel-Radic, A. (2013). “Estrangeirismo” and flexibility: Intercultural learning in brazilian MNCs. Management International/International Management/Gestiòn Internacional, 17(4), 239-253.

Bauchard, F. et al., Fusions: La Guerre des Cultures, Les Enjeux, 138, 2001, pp. 38-51.

Behrnd, V., \& Porzelt, S. (2012). Intercultural competence and training outcomes of students with experiences abroad. International Journal of Intercultural Relations, 36(2), 213223.

Bennett, M. J. (1993). Towards ethnorelativism: A developmental model of intercultural sensitivity. Education for the Intercultural Experience, 2, 21-71.

Bennett, J. M. (2009). Cultivating intercultural competence: A process perspective. The SAGE Handbook of Intercultural Competence, 121-140.

Bennett, M. J. (2013). Basic concepts of intercultural communication: Paradigms, principles, \& practice: Selected readings.

Bird, A., Mendenhall, M., Stevens, M. J., \& Oddou, G. (2010). Defining the content domain of intercultural competence for global leaders. Journal of Managerial Psychology, 25(8), 810-828.

Bolten, J. (2007). Einführung in die Interkulturelle Wirtschaftskommunikation [Introduction into intercultural business communication]. Göttingen: UTB.

Brach, C., \& Fraser, I. (2002). Reducing disparities through culturally competent health care: An analysis of the business case. Quality Management in Health Care, 10(4), 15-28.

Brookfield Global Relocation Services. (2016). Global relocation trends survey report: Breakthrough to the future of global talent mobility. Woodridge, IL: Brookfield Global Relocation Services.

Bücker, J., \& Poutsma, E. (2010). Global management competencies: A theoretical foundation. Journal of Managerial Psychology, 25(8), 829-844.

Byram, M. (1997). Teaching and assessing intercultural communicative competence. Clevedon, UK: Multilingual Matters. 
Cerdin, J.-L./Peretti, J.-M., Les déterminants de l'adaptation des cadres français à l'étranger, Revue Française de Gestion, 26, Juin-Aout, 2000, pp. 58-66.

Chang, W., Yuan, Y., \& Chuang, Y. (2013). The relationship between international experience and cross-cultural adaptability. International Journal of Intercultural Relations, 37(2), 268-273.

Chen, G. M., \& Starosta, W. J. (1997). A review of the concept of intercultural sensitivity. Human Communication, 1(1), 1-16.

Chen, G. M., \& Starosta,W. J. (1998-1999). A review of the concept of intercultural awareness. Human Communication, 2, 27-54.

Chen, G. M., \& Starosta, W. J. (2000, November). The development and validation of the intercultural sensitivity scale. Paper presented at the Annual Meeting of National Communication Association, Seattle, WA.

Clarke, C./Hammer, M. R., Predictors of Japanese and American Managers Job Success, Personal Adjustment, and Intercultural Interaction Effectiveness, Management International Review, 35, 2, 1995, pp. 153-170.

Collings, D. G., Scullion, H., \& Morley, M. J. (2007). Changing patterns of global staffing in the multinational enterprise: Challenges to the conventional expatriate assignment and emerging alternatives. Journal of World Business, 42(2), 198-213.

Cross, T. L. (1989). Towards a culturally competent system of care: A monograph on effective services for minority children who are severely emotionally disturbed. Washington, DC: Georgetown University Press.

Dale, J. M., \& Dulaimi, M. F. (2016). Cultural competence - a success factor in NGO projects? Built Environment Project and Asset Management, 6(2), 232-246.

Deardorff, D. K. (2006). Identification and assessment of intercultural competence as a student outcome of internationalization. Journal of Studies in International Education, 10(3), 241-266.

Deller, J., Interkulturelle Eignungsdiagnostik, in Thomas, A., Psychologie interkulturellen Handelns, Göttingen, Hogrefe 1996, pp. 283-316.

DiStefano, J. J., Maznevski, M. L., Creating Value with Diverse Teams in Global Management, Organizational Dynamics, 29, 1, 2000, pp. 45-63.

Earley, P. C. (2002). Redefining interactions across cultures and organizations: Moving forward with cultural intelligence. In B. M. Staw \& R. M. Kramer (Eds.), Research in organizational behavior: An annual series of analytical essays and critical reviews. (pp. 271-299): Elsevier Science/JAI Press. 
Earley, P.C., \& Ang, S. (2003). Cultural intelligence: Individual interactions across cultures.Palo Alto, CA: Stanford University Press.

Feitosa, J., Kreutzer, C., Kramperth, A., S. Kramer, W., \& Salas, E. (2014). Expatriate adjustment: Considerations for selection and training. Journal of Global Mobility, 2(2), 134-159.

Franck, G., Acquisitions américaines: Le management français en question, Revue Française de Gestion, 26, 2000, pp. 136-144.

Friesenhahn, G. (2001). Merkmale und Profil Interkultureller Kompetenz. In G. Friesenhahn (Ed.), Praxishandbuch internationale Jugendarbeit (pp. 65-66). Schwalbach: Wochenschau-Verlag.

Gertsen, M. C. (1990). Intercultural competence and expatriates. International Journal of Human Resource Management, 1(3), 341-362.

Graf, A., \& Harland, L. K. (2005). Expatriate selection: Evaluating the discriminant, convergent, and predictive validity of five measures of interpersonal and intercultural competence. Journal of Leadership \& Organizational Studies, 11(2), 46-62.

Hammer, M. R., Bennett, M. J., \& Wiseman, R. (2003). Measuring intercultural sensitivity: The intercultural development inventory. International Journal of Intercultural Relations, 27, 421-443.

Holmes, P., \& O'Neill, G. (2012). Developing and evaluating intercultural competence: Ethnographies of intercultural encounters. International Journal of Intercultural Relations : IJIR, 36(5), 707-718.

Johnson, J. P., Lenartowicz, T., \& Apud, S. (2006). Cross-cultural competence in international business: Toward a definition and a model. Journal of International Business Studies, 37(4), 525-543.

Josien, L. (2012). Enhancing expatriate selection: Measuring the strength of acculturation. Journal of International Business Research, 11(1), 83.

Kraimer, M., Bolino, M., \& Mead, B. (2016). Themes in expatriate and repatriate research over four decades: What do we know and what do we still need to learn? Annual Review of Organizational Psychology \& Organizational Behavior, 3, 83.

L'Hermitte, I. Différences culturelles et coopérations inter-entreprises: le cas des entreprises en joint-venture internationales, Doctoral thesis, Université Paris Dauphine: Paris 1998.

McNulty, Y., \& Brewster, C. (2017). Theorizing the meaning(s) of 'expatriate': Establishing boundary conditions for business expatriates. The International Journal of Human Resource Management, 28(1), 27-61.

McPherson, B., \& Szul, L. F. (2008). Business students must have cultural adaptability. Journal of Organizational Culture, Communications and Conflict, 12(2), 39-48. 
Mesmer-Magnus, J. R., \& Viswesvaran, C. (2008). Expatriate management: A review and directions for research in expatriate selection, training, and repatriation. In M. M. Harris (Ed.), Handbook of Research in International Human Resource Management, 183-206. New York, NY: Psychology Press.

Miller, J. W., \& Tucker, J. S. (2015). Addressing and assessing critical thinking in intercultural contexts: Investigating the distance learning outcomes of military leaders. International Journal of Intercultural Relations : IJIR, 48, 120-136.

Odell, C., \& Spielman, C. (2009). Global Positioning: Managing the Far-Reaching Risks of an International Assignment Program. Benefits Quarterly, 25(4).

Peltokorpi, V., \& Froese, F. J. (2012). The impact of expatriate personality traits on crosscultural adjustment: A study with expatriates in japan. International Business Review, 21(4), 734-746.

Perry, L. B., \& Southwell, L. (2011). Developing intercultural understanding and skills: Models and approaches. Intercultural Education, 22(6), 453-466.

Ryan, S. (2017). Rapport development and native language use between U.S. advisors and Afghan counterparts (Order No. 10263592). Available from ProQuest Dissertations \& Theses A\&I; ProQuest Dissertations \& Theses Global. (1884610537).

Sandage, S. J., \& Jankowski, P. J. (2013). Spirituality, social justice, and intercultural competence: Mediator effects for differentiation of self. International Journal of Intercultural Relations : IJIR, 37(3), 366-374.

Selmer, J. (2001). The preference for predeparture or postarrival cross-cultural training-an exploratory approach. Journal of Managerial Psychology, 16(1), 50-58.

Selmeski, B. (2009). Air university quality enhancement plan, 2009-2014: cross-culturally competent airmen. Maxwell AFB, AL: Air Force Cultural \& Language Center.

Shaffer, M. A., Kraimer, M. L., Chen, Y. P., \& Bolino, M. C. (2012). Choices, challenges, and career consequences of global work experiences: A review and future agenda. Journal of Management, 38(4), 1282-1327.

Spitzberg, B. H., \& Changnon, G. (2009). Conceptualizing intercultural competence. The SAGE handbook of intercultural competence, 2-52.

Spitzberg, B. H. (2015). Is past prologue, or just passed and lacking presence? International Journal of Intercultural Relations : IJIR, 48, 24.

Turnley, J. G. (2011). Cross-cultural competence and small groups. MacDill Air Force Base, Florida: The JSOU Press.

Van Dyne, L., Ang, S., \& Koh, C. (2009). Cultural intelligence: Measurement and scale development. In M. A. Moodian (Ed.), Contemporary leadership and intercultural competence: Exploring the cross-cultural dynamics within organizations (pp. 233-254). Thousand Oaks, CA, US: Sage Publications, Inc. 
Waller, D. C. (2011). Wild Bill Donovan: The spymaster who created the OSS and modern American espionage. New York: Free Press.

Yu, H. (2012). Intercultural competence in technical communication: A working definition and review of assessment methods. Technical Communication Quarterly, 21(2), 168-186. 


\section{Appendix}

\section{Question}

This reviewer worked as a liaison and advisor to foreign military, police, and civil government personnel. I also worked alongside others in similar positions. I observed that individuals with similar backgrounds and training who had been successful in more traditional military positions had widely varying effectiveness in these roles. Even special training for the work, while useful, was no guarantor of success. Subsequent historical reading revealed that inconsistent performance in this field was unique to neither my sample nor even my era. The Office of Strategic Services (forerunner to the Central Intelligence Agency) had experienced the same difficulty in similar work during World War II (Waller, 2011). Discussion with multiple USF professors confirmed that this was a topic of interest to business academics and practitioners.

One such professor, Dr. Adib Farhidi, put me in contact with Dr. Sean Ryan, a retired U.S. Army Colonel and a recent graduate of a doctoral program at Walden University. Sean has extensive experience as a foreign advisor. His dissertation was on the role language skill plays in establishing rapport and overall effectiveness. Sean and his colleague of many years, Thomas C. Rupert (Command Sergeant Major, U.S. Army, retired), provided a wealth of information and advice, but one of his most important contributions was to tell me the name of the construct I was talking about. The name he used was "intercultural adaptability." That phrase became the starting point for focusing my research - primarily through the USF Library System search engines (especially Google Scholar), and it led me to discover the other appellations.

Sean explained that the international business world had a keen interest in intercultural adaptability, because people with it were more effective at doing business with overseas suppliers and markets. Conversely, people without it could cost businesses a great deal of money. He used the example of executives sent (at great expense) to run overseas operations that returned home earlier than planned, having made no progress or even negative progress toward their objectives. This corresponded exactly with what I had seen in the military, where people were sometimes removed from positions that required dealing with local forces.

At this point my topic was clear, but my research question was still fluctuating. I knew that in the end, I wanted to provide organizations either a method of selecting personnel who had the traits and skills for intercultural roles or a means of developing them. My research revealed that there was a great deal of research already done on how to assess and cultivate intercultural competence, but the questions were far from settled. That left room for another doctorate on the subject - ideally, one that would offer an artifact to business and military leaders seeking to employ people in roles within certain well-defined parameters.

I would have to answer other questions first. How is intercultural competence defined? Why is it important? What is the model that explains this construct? These questions would help me narrow my research and prepare me to do original work in the field. These questions are the topic of this review.

\section{Permissions}

No permissions were required. Quoted text was used within academic fair use policy. 